QK 49

.D4

Copy 1 


\section{LIBRARY OF CỌNGRESS, COPYRIGHT OFFICE.}

No registration of this book as a preliminary to copyright protection has been found.

Forwarded to Order Division JUN 15 isio

(Apr. 5, 1901-5,000.)
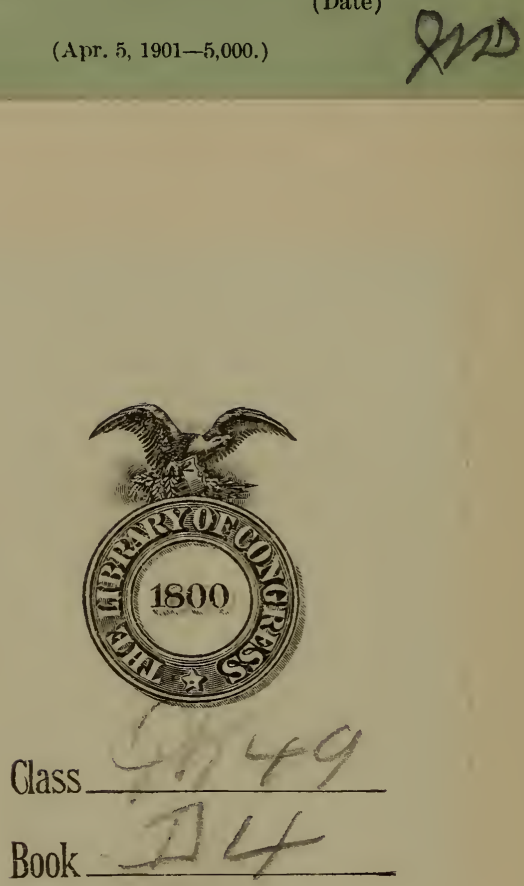

$-$ 






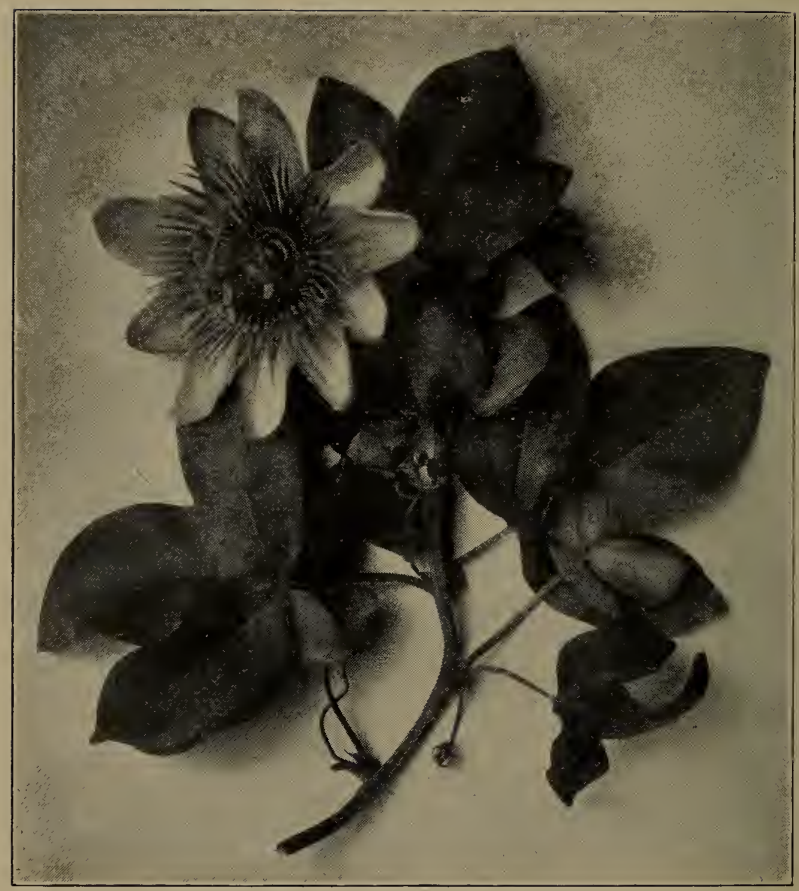

Fig. 77.

A passion flower. Photographed by the late Dr. J. R. Weist. 


\title{
NATURE STUDY
}

\section{ONE HUNDRED LESSONS ABOUT \\ PLANTS}

\author{
BY \\ DAVID WORTH DENNIS, \\ Professor of Biology in Earlham College.
}

With More Than One Hundred and Fifty Illustrations.

Marion, Indiana.

Teachers Journal Printing Co., 1906. 


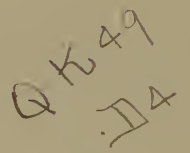

Copyright, 1903,

$$
\text { BY }
$$

O. W. FORD \& CO.

Keceived from

Copyrisht Office.

IUN : 61910 
This Book is Dedicated to all who Are Helped by it. 



\section{PREFACE}

Nature Study is new; Liebig was the first man who used a laboratory for instruction. He began his career as a teacher in 1824 .

Courses in mathematics and language have had centuries in which to perfect their methods of instruction and the lessons it is best to offer; for this reason, lessons in these subjects are good, if not the best, that can be offered, and the methods of giving them have had opportunity to eliminate errors. The teacher of nature study has almost no past to guide him. The older teachers of nature study were not themselves taught in schools. As a department of instruction it is without traditions or precedents. Every serious teacher so far has had to pave his own road. All teachers have gone different roads. It could not be otherwise.

The material with which nature study deals, is inexhaustible; no one can ever be acquainted with more than an insignificant fraction of it. It is all good. It will always be the case that successful teachers will give what they know. They will accordingly teach different things. It is probably true that every successful teacher has, from year to year, taken his pupils over different ground, and that everything done has proved to be good. That it is best to teach we cannot yet tell, in other words, than that that material is best.which can be had.

This nature study work has passed through three phases. It was first taught from books. The only nature study work I ever did in school was in Geography and Physiology and every syllable of these came from books. We next added the laboratory. How new this phase of the subject is, may be learned from the presidential address of Dr. Wiley before the Indiana Science Teachers' Association at Lafayette, in 1895. He says: "Prior to 1863 no laboratory instruction was given in Indiana except a little in qualitative analysis."

Much has come from the laboratory as a means of instruction. But we had not been trying it long when we learned that though the laboratory, like the book, is a great help, still it is not enough. Aristotle had set us our task; Zoology has its end not in what an animal is or what it does, but why it does it. Fitness is the real Zoology. We had studied the sucker in books and learned much; 
we brought him to the laboratory and learned more, but the sucker had spots. Why did he grow them? We had to go to the brook for answer; his spots resemble the stones on the bottom of the stream. He grew them in imitation of this bottom, and he thus often escaped his enemies. This brought us to the third phase, the outing. This is now in full swing; nature study of whatever degree cannot do without it. The Gulf Stream and the Rocky Mountains we cannot take to the school, but we can and do take the school to them.

It is now known that nothing we ever did was wholly wrong. The book, the laboratory, the outing, all were necessary. This book emphasizes the outing, but contemplates the use of book and laboratory as well.

The outing, to be successful, must have a definite purpose and nearly all the lessons and exercises here given hold up one thing to be learned.

This one thing should be important. The teacher and pupil alike should be able to see that the lesson is worth while. Terns incidentally necessary to the learning of the lesson should be acquired by use first. Let definitions wait until they are needed. The excuseless thing that nature study has done is: it has piled up definitions of parts, forms, disguises, etc., by the hundreds of pages and has turned them on in installments, away from what they represent and apart from any possible use that the learner could see. This book has been written with the conviction that this ought to stop. If it has left undefined any necessary terms for any lesson, Webster, Worcester or the Century at least, will supply the omission.

It has been the constant aim of these pages to put the student in possession of guiding principles,--something that will help him interpret what he sees. Nearly all the lessons consider, in one form or another, the plant in question as a species that has won in the struggle for existence and they direct attention to the adaptations that have enabled it to win.

It is my conviction that knowledge on the part of the teacher is the chief thing we lack. This consideration has led me to confine these lessons to a field so limited that it would be possible for the faithful teacher to gain the necessary knowledge. I do not see how I could. give these lessons without knowing the plants in question by name. This is the first thing children ask and the best way to induce them to learn the important things the teacher assigns is for him to tell them the unimportant (?) things they 
ask. These lessons mainly deal with common trees; but a teacher should have a good manual of botany and know how to use it to find the name of a plant. For the Ohio Valley, Gray's Manual is a good one for determining the names of flowering plants. Apgar's Trees of the Northern United States will enable any teacher to find the name of most, if not all, trees by their leaves only. A good general botany is Campbell's University Botany. Three good smaller works are Bailey's Elementary Botany, Coulter's Plant Relations and Plant Structures, and Atkinson's Elementary Botany. The catalogue prices of these books and their publishers, are as follows:

Bailey's Elementary Botany, The Macmillan Co., $\$ 1.10$.

Coulter's Plant Relations, \$1.10; Coulter's Plant Structures, $\$ 1.20, \mathrm{D}$. Appleton $\&$ Co.

Atkinson's Elementary Botany, Henry Holt \& Co., \$1.25.

Campbell's University Botany, The Macmillan Co., \$4.00.

Apgar's Trees, The American Book Co., \$1.00.

Gray's Manual, The American Book Co., \$1.65.

A summer term in some lakeside or seaside laboratory, would be of the greatest value to any prospective teacher of nature study. It may be depended upon that in science, with fullness of knowledge, enthusiasm and some good way to teach, will follow.

There is another sort of literature that the teacher should use for the sake of the pupil: Stories and poems by masters that treat directly or indirectly of plants. Only selections should be used that are worthy; that belong to enduring literature. The following list will show the character of the reading to which I refer:

Bryant, "The Yellow Violet," "The Fringed Gentian," "The Death of the Flowers;" Wordsworth, "The Oak and the Broom," "Daffodils"- "I wandered lonely as a cloud," "To the Celandine;" Emerson, "The Rhodora;" Burns, "To a Mountain Daisy;" Dickens, "The Ivy Green;" Holmes, "Album Verses:" Southey, "The Holy Tree;" Santine, "Picciola;" Thoreau, "The Succession of Forest Trees;" Kipling, "The Jungle Books."

In addition to these there are hundreds of other worthy references to plants in the works of all our standard authors, from Shakespeare to Riley. Hunt them up and they are yours.

\section{NATURE STUDY AND THE CHILD.}

My last recommendation may be criticised or called sentiment or anything else, so the critic remembers it concerns itself with the child's need; his nature; his demands; the child's imagination is fairly riotous and must be directed; because poetry and story 
were the first phases of the world's literary activity, they appeal to the mind of the growing child. Let him have them, part of the time, and let them wed him to his more serious nature study as they are sure to do. It is maintained that the imagination is to be cultivated, but not in connection with nature study. But suppose history teachers fence their preserve the same way? and teachers of religion and sociology?

It has been said that this child preference for poetry, story, myth and the heroic, is a "passing phase;" the tadpole's tail is a "passing phase" but the stronger you make it the further the frog will be able to jump. Lat the child enjoy nature study, science can stand it in any event and will gain by it if it helps the child. As his interest in the subject grows, his need of any fanciful presentation will decline.

The child's powers of observation are proverbial; his desire for knowledge is keen; it is universal among normal children; his curiosity leads him to ask questions; disapproval or even punishment will not stop his questioning. He only leaves it off when he despairs of an answer. His impossible questions mean only that his mind is awake and hungry; show him something it is worth while for him to see or tell him something worth knowing and keep this up to the point of weariness; then let him rest; let this go on through the grades and nature study will have done for him its best. How many curious, inquisitive children and how few curious, inquisitive men! Nature study, if anything, can remedy this. In the past, from the kindergarten or home to the high school or college, our instruction has been almost wholly in books; during this period, the pupil's confidence in his power to see often almost wholly disappears. Ask a class of a hundred freshmen to learn how many gills a crawfish has, and the many will go to the library, the few to the brook. What a blessing nature study would be if it could keep alive throughout the formative period, the child's native desire to know at first hand. It would give to 
the race as many Aristotles and Darwins as child endowments promise us.

The child has tasks enough; tasks which he must not only do but remember for the quiz. Why not interest him in something without the imminence of a judgment day. Ten inspiring minutes twice a day and an outing twice a week, when the weather is suitable, with the blessed privilege which men universally enjoy of forgetting if he wants to, will put a spirit into all his tasks that will surprise every one in its results. The one big result will be that learning will become attractive.

I am under obligation to Prof. H. B. Dormer, of Purdue, for Figure 30. to Prof. J. F. Thompson, of the Richmond High School for Figures 29, 54, and 87, and to Mr. A. MI. Mahaffy for Figure 139; to Miss Helen M. Fiske for several drawings and to Mr. George Bond, Mr. Vivian Floyd, Miss Ruth Trueblood and Mr. Charles H. Frazee for permission to photograph microscopic slides; all of these are credited in connection with the several illustrations. A few illustrations have been copied from different sources and are acknowledged in the accompanying cut legends. I am under special obligations to Prof. David M. Mottier, of the Indiana University, and to Prof. J. F. Thompson, of the Richmond, Indiana, High School, who have read all the proof. Their suggestions have been very valuable and I have been able to turn them all to account. I assume all responsibility, however, for both the subiect matter and the method of presenting it.

I take pleasure in adding to the list of books given on page VII of this preface at Prof. Mottier's suggestion, Stevens' Introduction to Botany. D. C. Heath \& Co.

DAVID WORTH DENNIS.

Earlham College, June, 1903. 



\section{CONTENTS.}

\section{Adaptation to Light.}

Lesson.

I. The Disposition of the Branches of a Beech Tree 1

II. The Tree Grown in the Open Country and the

Forest Tree.................... 3

III. The Branching of a Fir-Tree............ 6

IV. The Branching of the Elm............. 8

V. Unequal Lighting.................. 9

VI. Pendant Branchlets.................. 11

VII. Horizontal and Vertical Branches........... 12

VIII. The Behavior of the Petiole.............. 14

IX. The Behavior of the Petiole. The Maple Spray.. 15

X. The Aspen. The Prickly Lettuce............. 16

XI. The Shape of the Leaf-Blade ............ 17

XII. The Rosette Leaf-Arrangement . . . . . . . . . 21

XIII. The Stem's Main Duty................ 21

XIV. The Sleep of Plants . . . . . . . . . . . . 24

XV. The Leaf-Arrangement of the Beech Tree .... 27

XVI. Leaf-Arrangement.................... 28

Pollination.

XVII. Self-Pollination.................... 32

XVIII. Staminate and Pistillate Flowers. A Monoecious Species................... 33

XIX. The Advantage which the Monoecious Species Has. .......................... 35

XX. The Dioecious Species ............... 36

XXI. Flowers in which the Pistil Appears First . . . . 37

XXII. Flowers in which the Anthers Appear First .... 38

XXIII. Flowers and Insects. Bees ............... 40

XXIV. Flowers and Insects. Butterflies and Moths ... . 41

XXV. Symbiosis.-"Reciprocity." ............. 42

XXVI. How the Ants Are Kept Out ............ 44

XXVII. Flowers that Never Open .............. 45

XXVIII. Results of Experiments in Cross and SelfPollinated Plants of the Same Species. . . . . 46

XXIX. Why Flowers Are Showy............... 47

XXX. Why Trees Have Not Showy Flowers ........ 48 


\section{Adaptation to Climate.}

Lesson

XXXI. Storms ...................... 49

XXXII. Annual Herbs . . . . . . . . . . . . . . . 50

XXXIII. Biennial Herbs . . . . . . . . . . . . . . . 51

XXXIV. Perennial Herbs. Solomon's-Seal . . . . . . . . . 53

XXXV. Deciduous Forests. . . . . . . . . . . . . . . . 54

XXXVI. Evergreen Leaves . . . . . . . . . . . . . . . 55

XXXVII. Buds........................ 57

XXXVIII. The Persimmon Tree. A Special Case . . . . . . . 59

XXXIX. The Influence of the Wind ............ 60

\section{The Leaf.}

XL. The Foliage Leaf. .................. 62

XLI. One Duty of Green Leaves.... . . . . . . . . . . . . 64

XLII. Leaves in the Role of Spines.............. 65

XLIII. Leaves in the Role of Bracts . . . . . . . . . . . . 66

XLIV. Leaves in the Role of Sepals and Petals .... . . . 67

XLV. Leaves in the Role of Stamens ............ . 69

XLVI. Leaves in the Role of Pistils ............. . 70

XLVII. Leaves in the Role of Bud-Scales. . . . . . . . . . . 71

XLVIII. Leaves in the Role of Bulb-Scales . . . . . . . . . 72

XLIX. The Pappus of the Dandelion ............. 74

L. The Blossom End of the Apple ......... 75

LI. Leaves in the Role of Tendrils ............ 77

LII. How Tendrils Behave................ 78

LIII. How the Bean Finds its Pole.............. 79

\section{Seed Dispersal.}

LIV. The Multitude of Plants. The Struggle for Existence..................... 80

LV. The Winged Seed of the Linden ........... . 82

LVI. Other Seeds with Wings ............. 83

LVII. The Dandelion's Parachute ............. 84

LVIII. Other Pappus-Bearing Seeds. . . . . . . . . . 87

LIX. Some Adaptations of the Thistle.......... 88

LX. Smallness of Seeds and Spores............ . 89

I.XI. The Spanish Needle . . . . . . . . . . . . . . 91

LXII. Other Seeds that Cling................ 93

LXIII. Currents of Water.................... 93

I.XIV. Fruit. The Service of Animals that Eat it.... 94 
L.Y. Nuts and Animals................... 95

LXVI. Special Contrivances.................. 96

LXVII. Special Contrivances.................. 98

LxviII. A Seed-Dispersal Table .............. 99

\section{Plant Societies.}

LXIX. Water Plants . . . . . . . . . . . . . . . . . . 101

LXI. Microscopic Plants ................... $10 t$

LXXI. One Plant Adapted to Live in Water.......... 105

LXXII. Desert Plants. . . . . . . . . . . . . . . . . . . . 109

LXXIII. Adaptation to Moisture. Land Plants ......... 111

LXXIV. Some Advantages of Mass Life. Society Life . . 112

LXXV. A Walk in the Woods. Forestry ............. 113

\section{Stems.}

LXXVI. The Fibro-Vascular Bundle................115

LXXVII. The Arrangement of the Fibro-Vascilar Bundles in Exogens..................... 117

LXXVIII. Growth of Wood in an Exogen............ 119

LXXIX. Quarter-Sawed Oak .................... 123

LXXX. Heart-Wood. . . . . . . . . . . . . . . . . . 124

LXXXI. Stem Disguises .................. 126

LXXXII. Why the Yellow Violet Comes so Early in Spring ................

LXXXIII. Bark ..........................

LXXXIV. Ashes....... . . . . . . . . . . . . . 129

LXXXV. The Root ........................ 130

LXXXVI. Why Clover Helps the Soil.............. 132

\section{Uses of Plants.}

LXXXVII. Plants and Starch . . . . . . . . . . . . . 134

LXXXVIII. Plants and Food ...........................

LXXXIX. Plants and Clothing, Medicine, etc. ......... 136

XC. Lumber and Fuel ................... 137

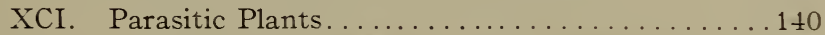

XCII. The Plant's Chief Work. Saprophytic Plants ...14t

XCIII. Chlorophyll .................... 146 


\section{Protoplasm.}

XCIV. Differences Between Animals-and Plants . . . . . . 148

XCV. The Respiration of Plants .............. . 150

XCVI. The Cell ....................... 151

\section{How Plants Multiply.}

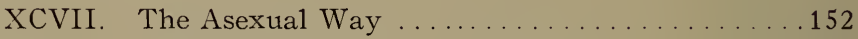

XCVIII. The Sexual Way . . . . . . . . . . . . . . . . . . 156

XCIX. Growth from the Cell to the Tree . . . . . . . . . . . 164

C. Cell Duties in a Many-Celled Plant..... . . . . . 164

CI. Young Plants...................... 166 


\section{NATURE STUDY.}

\section{ONE HUNDRED LESSONS ABOUT PLANTS.}

\section{LESSON I.}

\section{Adaptation to Light.}

The Disposition of the Branches of a Beech Tree.

Figure 1 shows a beech tree in its winter condition. It will be noticed that its lower branches droop; higher up they are horizontal; higher still they rise. Why is this? It cannot be that gravity alone makes the lower branches droop for it acts on all alike. Look more closely and see if the disposition of all the branches of the beech tree is not such as to get its leaves to the light to the best advantage. During all our observations on trees we should test the following: The one main purpose of the stem of the tree, its trunk and its branches, is to get its leares to the light.

Exercise: Every pupil should draw a beech tree as accurately as he can, but it should show the disposition of the branches above referred to. "A pencil is a good eye." Examine also a sun flower to see if it gets its leaves to the light in a similar manner; do the petioles of the lower leares droop; and those of the middle leaves grow in a horizontal direction while those of the uppermost leaves rise? 


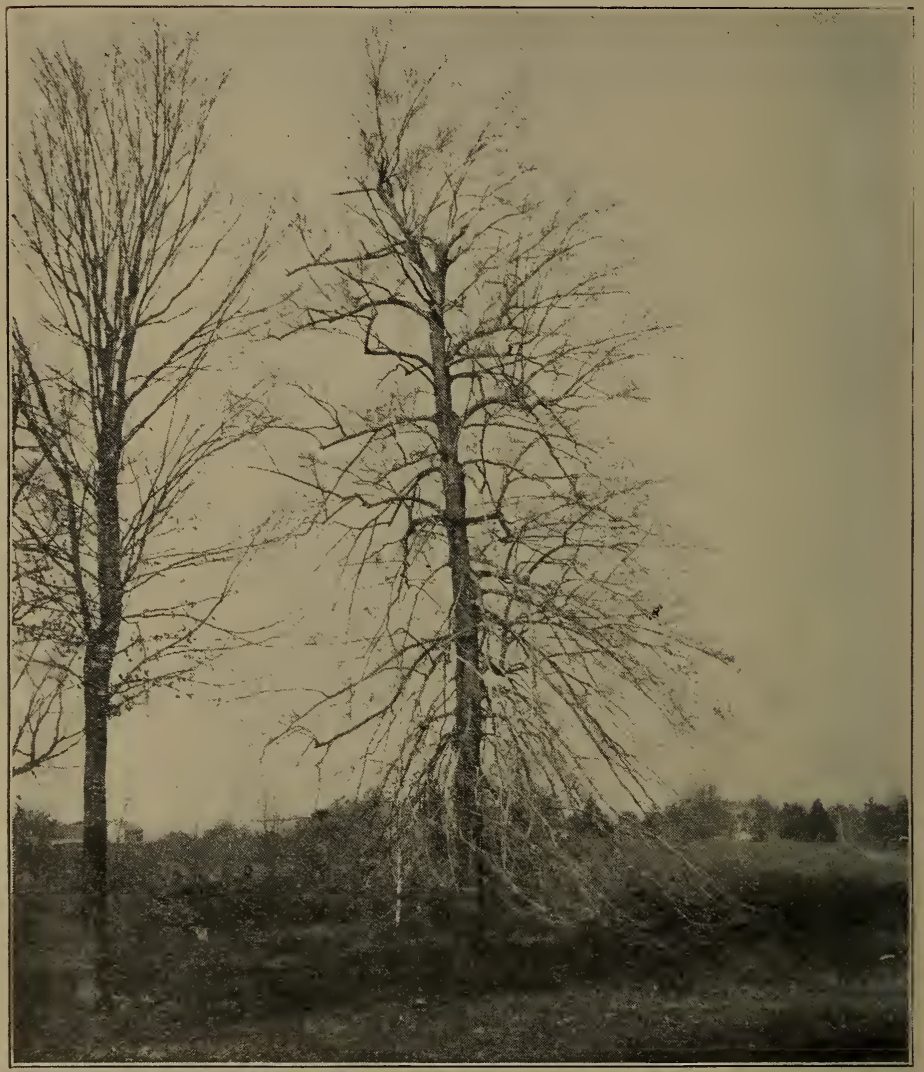

Fig. 1.

A beech tree showing how its branches get their leaves to the liglit; the lower droop, the mirdle grow straight, and the upper rise. 


\section{LESSON II.}

\section{Adaptation to Light.}

The Tree Groun in the Open Country and the Forest Tree.

Visit a walnut, oak, ash, or wild cherry tree that has grown in the open country and one that has grown-in the

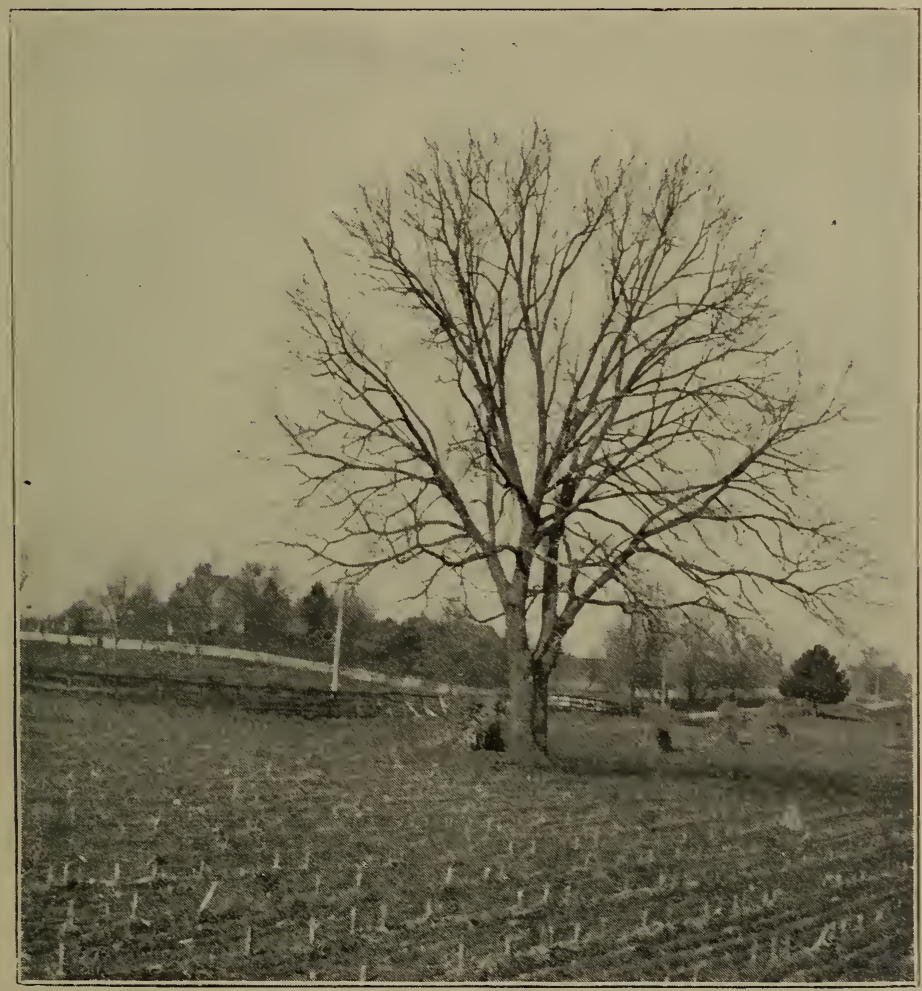

Fig. 2

This walnut tree grew in an open field; light called and its branches responded ni all directions. It was photographed at the same distance as Figure 3 . 
forest. How high is the tree in each case? How high is the first branch? It will be seen that in the open, every branch has responded to the influence of the light, has lived and

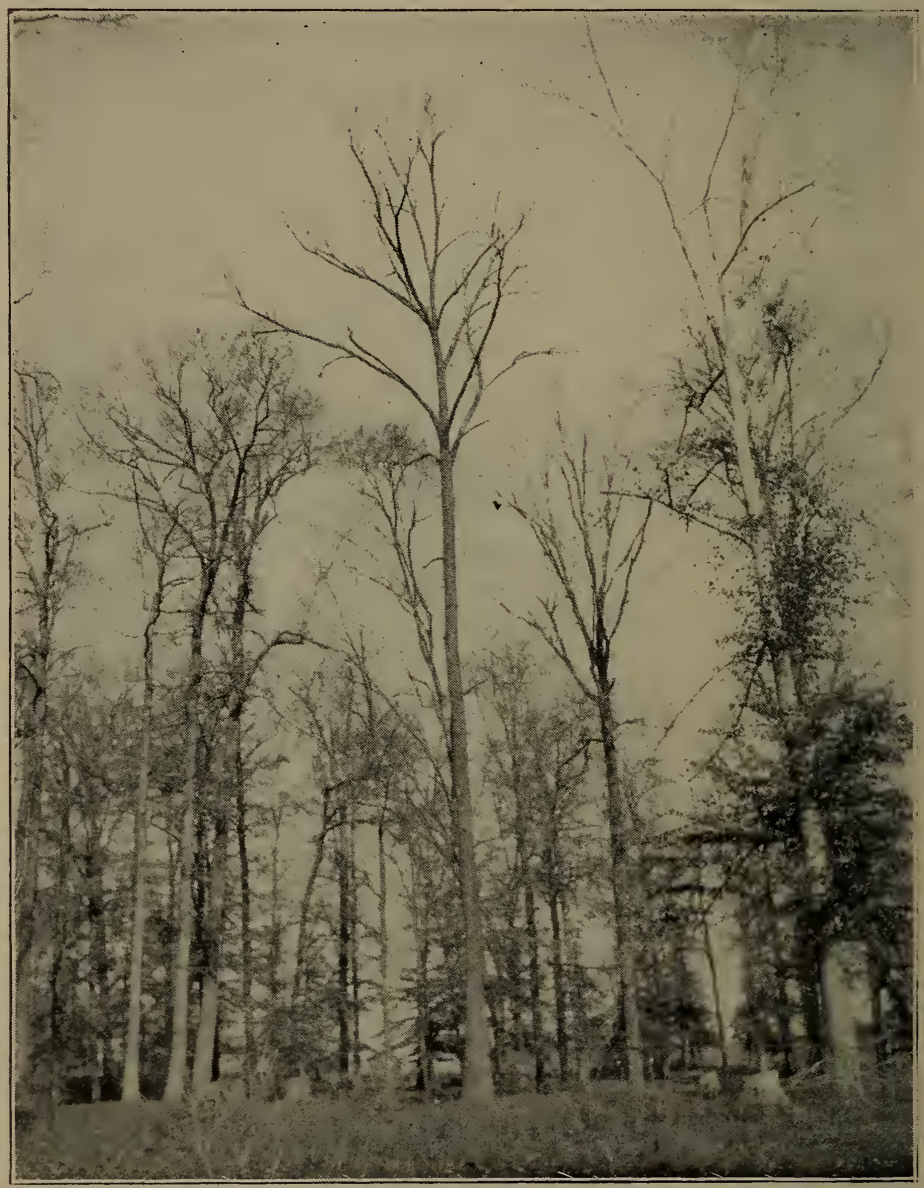

Fig. 3.

This walnut tree grew in the woods; light was to be had from above only; its lowest, shaded limbs died; it is a tall tree. 
has grown vigorously toward the light; horizontal branches are sometimes found as large as considerable trees in the forest. In the forest, neighboring trees have shut out the light and the lower branches have died; the highest branches, called upward still by the light, have grown and grown until the result is what we call the monarch of the forest. Fig 2 is a walnut tree grown in a field; Fig 3 is a walnut grown in the forest. These photographs were made at the same distance from the trees and correctly represent their dimemsions. The circumference of Fig 2 is $93 / 4$ feet; that of Fig 3 is $43 / 4$ feet. So the country tree is much the older. The forest tree is, however, much taller and its lowest limb is much higher. In the pine forests of Europe, it is a business for some women, children and old men to cut off the under branches that have died in the shade and gather up others that have fallen and bind them in bundles for kindling purposes.

Exercise: Find and draw a tree that has grown alone in the country.and one of the same kind grown in the forest, care being taken to draw them to a correct scale. Measure both trees just as they grow.

\section{How to Measure a Growing Tree.}

First, measure the height of, your eye on the tree trunk, and mark the spot c. Walk back 100 feet from the tree to e and set up a pole between you and the tree so you can just see the top of the tree $\mathrm{d}$ over the top of the pole a. Mark the point on the pole $\mathrm{b}$ between your eye and the spot $\mathrm{c}$. Now measure the distance ab; we will suppose it to be 6 feet. Measure the distance eb from your eye to $b$; we will suppose it to be 10 feet. Now the distance dc is as many times ab as 100 feet is times eb. This is ten; therefore the 
tree is 10 times $6=60$; add to this the height of your eye, 4 feet, and you have 64 feet, the height of the tree. Or if you understand it-eb:ec::ab:dc. 10: 100::6: height of the tree above your eye.

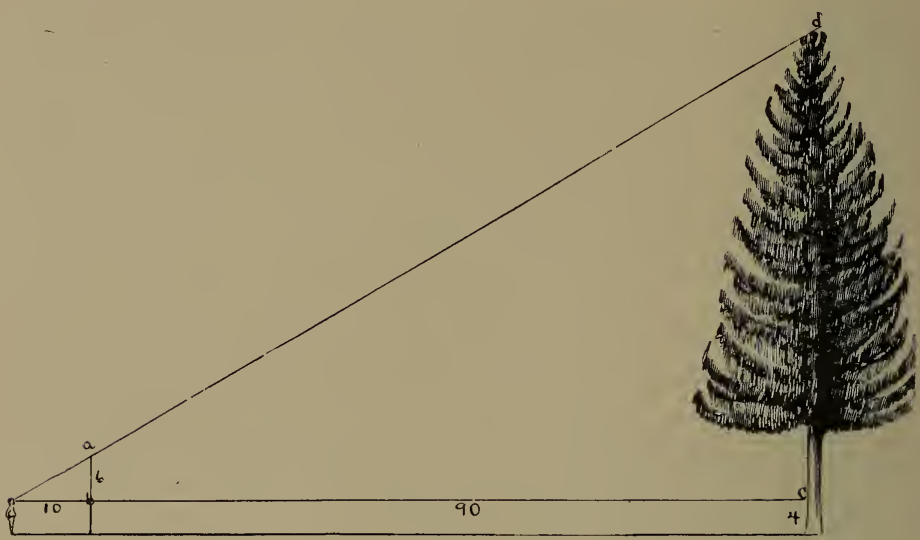

LESSON III.

Adaptation to Light.

The Branching of a Fir-Tree.

Figure 4 is a fir-tree. You can tell a fir-tree from a spruce or hemlock by its leaves which have no petioles, but are attached to the branch by a slightly enlarged disk. Notice how perfectly conical its top is; the light makes it so. Go under the tree, close to the trunk and look up. You will see that the branches are bare except at the extremities. The leaves have all died where they were in shadow. Because the branches grow gradually shorter from below upward, the upper ones cannot shade the lower at their ends; here the leaves grow. When a tree has one main branch from root to top as this tree has, we call its branching 
excurrent. But it is far less valuable for you to remember this than it is for you to understand that this is one way for every branch to get some of its leaves to the light.

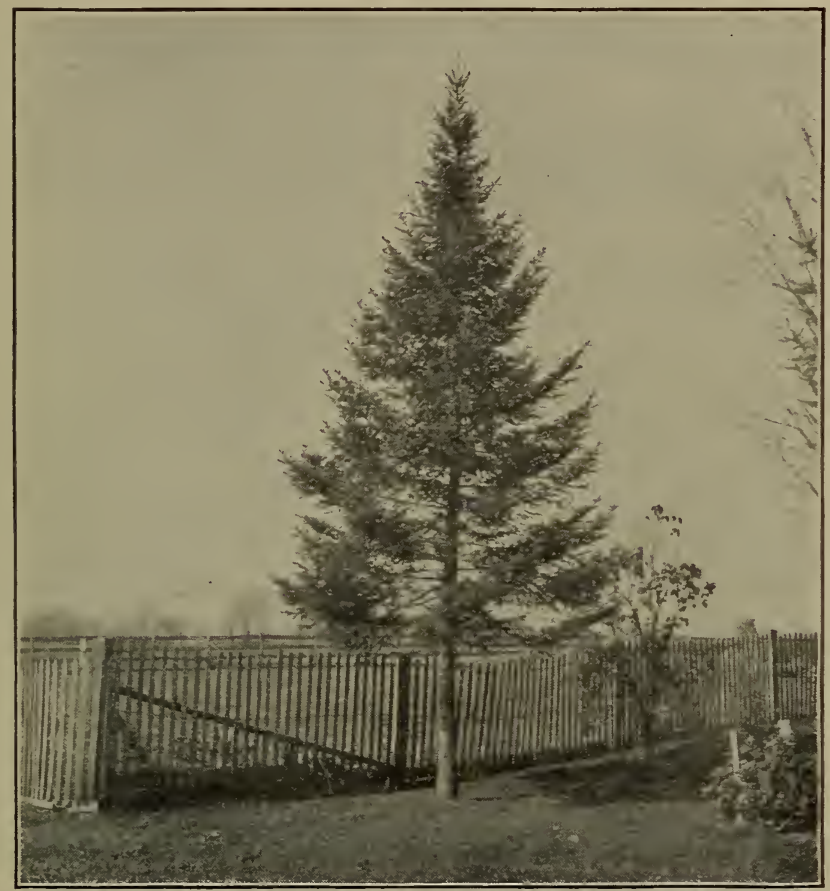

Fig. 4.

A fir-tree; excurrent branching; every branch reaches a little farther than those above it and so all get the light.

Exercise: Find a fir-tree and sketch it to a correct scale; go back to the beech again and see if its branching is also excurrent. See if you can find a fir-tree, the branches of which droop like those of the beech. 


\section{LESSON IV.}

\section{Adaptation to Light.}

\section{The Branching of the Elm.}

Figure 5 is an American elm in its winter condition. Notice that there is no main trunk above its lowest branches. Find the tree growing out by itself where every branch has

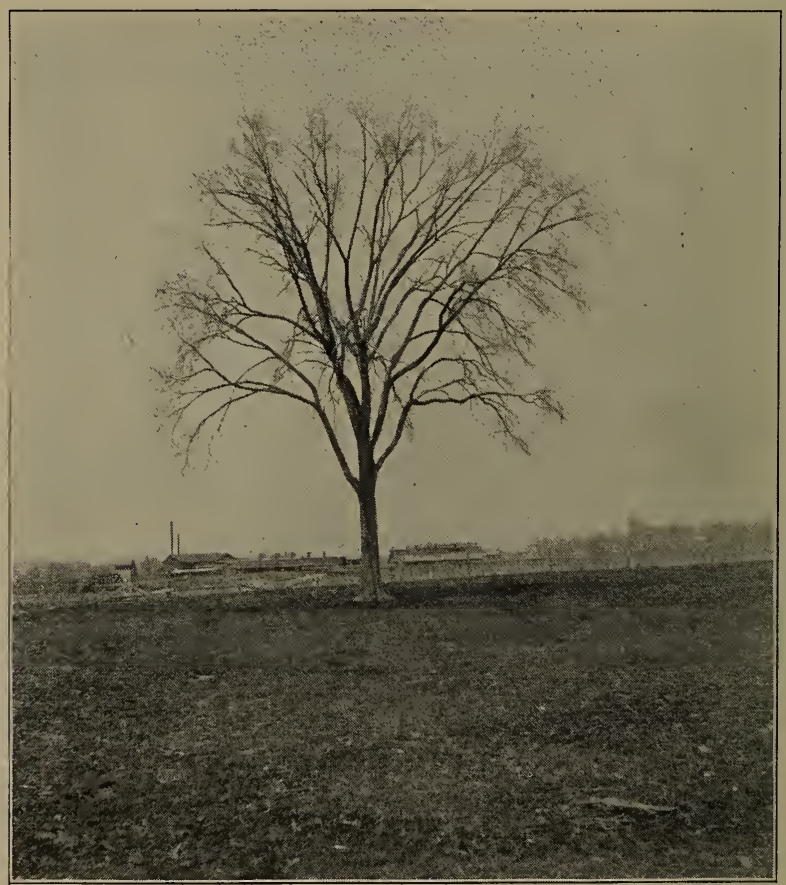

Fig. 5 .

The elm; deliquescent branching.

an equal chance at the light. When a main trunk divides up into two or more somewhat equal branches and these 
branches divide in somewhat the same way, we call this method of branching deliquescent. But the important thing for us to consider is whether every branch grows in the direction that will most quickly and certainly bring its leaves to the light. If the attraction of the light is the determining thing and there is a flood of it in all directions should we not expect a symmetrical top like this?

Exercise: Draw the elm showing its manner of branching. Find twenty different kinds of trees and determine for each of them whether the branching is most like the fir or the elm. Is the apple excurrent or deliquescent in its branching? The cedar?

\section{LESSON V.}

\section{Adaptation to Light.}

\section{Unequal Lighting.}

You are sure to see lack of symmetry in a tree, grown where one side is in light and one in shadow. Figure 6 shows a pitch-pine that has grown in a clump of evergreens. The main branch on the light side is 18 feet long. The longest branch on the other side is only 4 feet. A wild cherry tree growing between a linden and a sycamore near my home, is flat because it is shaded on two sides and not on the other two; its expanse from the light side to the light side is 40 feet while from the shady side to the shady side is only 20 feet.

Exercise: Find a tree somewhere so grown that it has little light on one side; it may be on the edge of a forest or 
on the outside of a group of trees or near a building. Measure its expanse of branches and draw it to a scale. Find

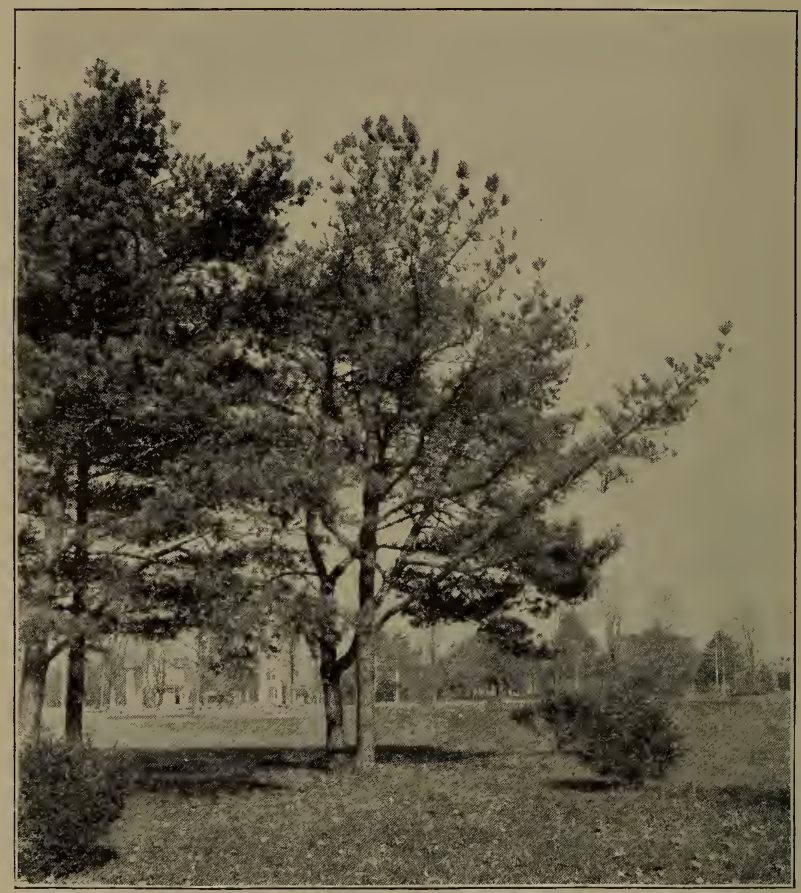

Fig. 0 .

The pitch-pine; the branches on the shady side are to those on the sunny side in lengih as $4: 18$.

enough such trees so that you will feel sure that the amount of light is one important thing in determining vigor and direction of growth.

Consider the lilies of the field, how they grow. 


\section{LESSON VI.}

\section{Adaptation to Light.}

Pendant Branchlets.

Notice Figure 64, Lesson XXXIX, and you will see that the circles of limbs are some distance apart; this leaves light spaces between them in which pendant branchlets have grown down and brought their leaves to the light. Find a Norway spruce and see that this is one of its characteristic habits of growth. You can tell a spruce from any tree that closely resembles it by the short, brown stems of its leaves. These pendant branchlets of the spruce give it a peculiar appearance in the distance. It should be one aim of our nature study work to name as many tiees as we can by their figures at a distance of fortv rods or so. The European larch has the same habit. It can be told from the tamarack, the tree that looks most like it, by its pendant branches. 


\section{LESSON VII.}

\section{Adaption to Light.}

\section{Horizontal and Vertical Branches.}

Figures 7,8 and 9 show three branches of Norway spruce; 7 grew directly upright; 8 shows a side view, and 9 the view from below of horizontal branches. The vertical branch is round; the leaves grow on all sides of the branch; they

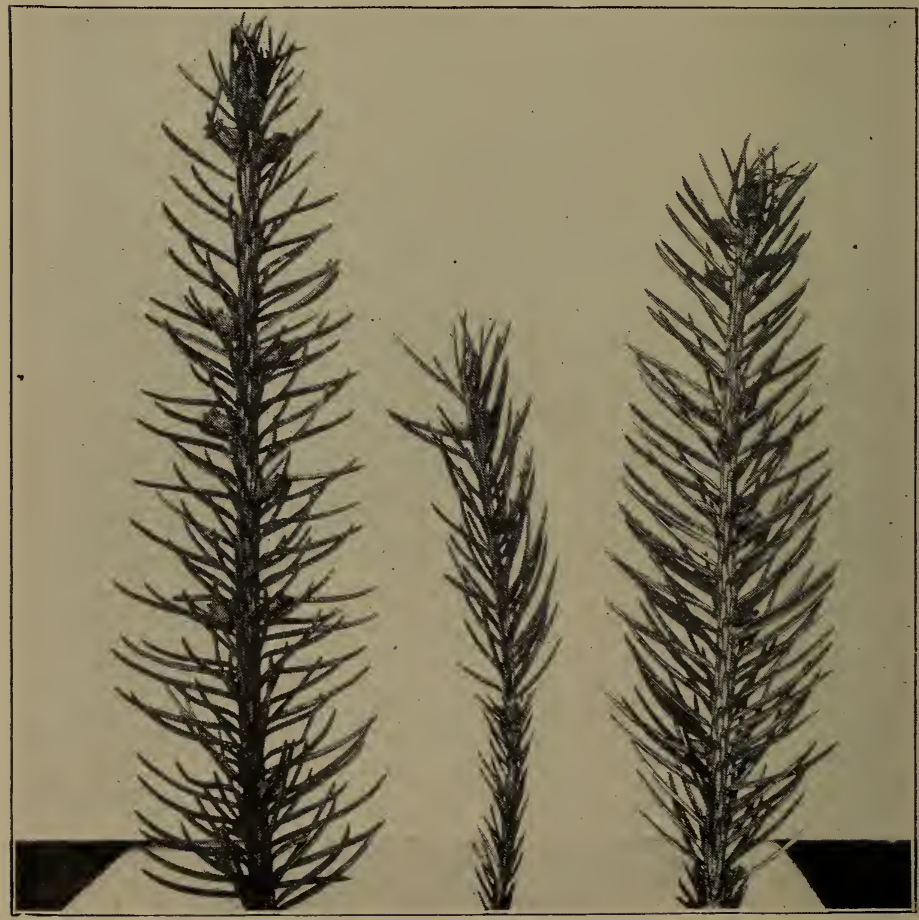

Fig. 7.

Fig. 8 .

Fig. 9.

Fig. 7. A round spruce branch; it grew upright and had light in all directions; Fig. 8"was horizontal and is flat: if turned through 90 degrees it would appear as wide as 7 or 9 . Fig. 9 was horizontal and is seen from below. 
grow in like manner on all sides of the horizontal branch but the under leaves come around to the side in order to get to the light. The same lesson may be equally well learned from a hedge that is just ready to be trimmed; some of the long, fresh shoots will be found growing straight up, and,

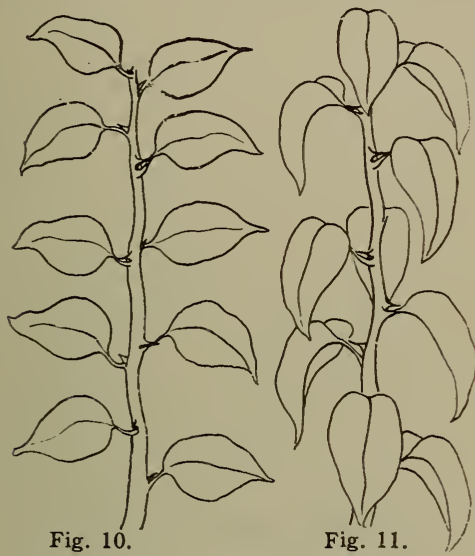

Fig. 10, a hedge branch that grew horizontal. It is flat. Fig. 11, a hedge branch; it grew upright and round. Drawn from nature by Miss Helen M. Fiske. as there are eight rows of leares on the stem it will appear round in full leaf, Figure 11; other branches will be found that have taken a horizontal direction and the leaves of these will have crowded together on the two sides and the branches will appear flat, Figure 10. Apple or peach branches will show the same thing, only there are but five vertical rows of leares on these branches.

If a two-ranked stem like beech, elm or hazelnut is studied it will be found that on a horizontal branch the leaves lie in the plane of the branch -look at right angles to it. On a rertical branch so grown that its light comes from abore the leaves have turned ninety degrees on their stems and face the tip of the branch.

Examine and see if it is the petiole that brings the leaves into these varying positions.

Notice that the leaves of the spruce are short and narrow and that there are many vertical rows on the branches with the leaves close together; the hedge has broader and longer leaves with fewer rows and the leaves in its rows much farther apart. Does this ratio hold generally for leaves; the wider and longer the leaves the fewer the rows and the farther apart? 


\section{LESSON VIII.}

\section{Adaptation to Light.}

\section{The Behavior of the Petiole.}

Examine a pumpkin-vine; it will be found that the petioles that come out on the upper side grow straight and spread their leaves out directly above; but petioles coming from the under side curve round and then grow out at the angle best suited to bring their blades to the light.

Examine a morning-glory or any other sort of twining vine; the petioles that leave the vine on the side next to the support all bend around so as to bring their blades to the light. Make the same study of a Virginia creeper growing on the side of a house. Is not the petiole of a leaf a contrivance to bring the blade to the light? Does it not grow straight or crooked, long or short, up or down or out, in order that it may do this? Pull a branch from the Lombarciy poplar; its branches cling close to the tree,-grow almost straight up. Have the petioles all brought their blades around so as to face the light? 


\section{LESSON IX.}

\section{Adaptation to Light.}

\section{The Beharior of the Petiole. Maple Spray}

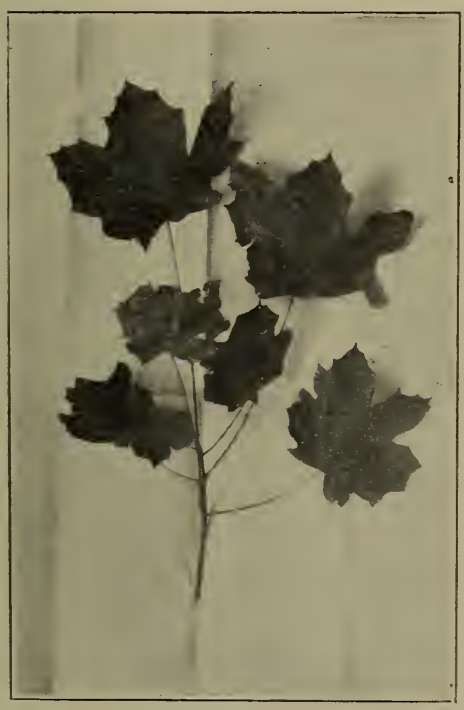

Fig. 12. petioles of lower leaves.
A maple spray, showing the longer

Figure 12 shows a maple spray. Study this figure with a maple spray before you. Study it at the tree; for the direction of growth, or the length of a petiole will often be determined by the shadow of leaves on a neighboring spray or on neighboring trees. Compare the maple spray with the beech spray, Lesson XV. Notice that on the maple branch there are four rows of leaves while on the beech branch there are but two. Notice again that beech leaves on the same spray cannot shade each other, that the maple leaves can and that they escape this calamity by the varying length of their petioles and their direction of growth. It must be some trouble and expense to a leaf to grow a long petiole, and if nothing is gained by it why should it do su? Do not pass from this lesson till you can see why the beech does not need long and short petioles, while the maple does. Study Lessons IX and XV together. 


\section{LESSON X.}

\section{Adaptation to Light.}

The Aspen. The Prickly Lettuce.

The aspen, the Carolina poplar, the Balm of Gilead, the Lombardy poplar and a few other rare poplars have the petioles of their leaves flattened vertically so that the leaves quiver in the slightest breeze. Study this feature of the aspen tree if possible. Scott, in order to tell how perfect the calm, says,

\section{"Scarce the frail aspen seemed to quake."}

This quaking permits the light to fall on leaves that otherwise would be in shadow.

The common prickly lettuce furnishes an interesting study; its leaves turn 90 degrees on their axes near the stem so that the leaf stands edgewise; they also turn so as to point in a general north and south direction from which it is often called the "compass plant." The effect of both these movements is to lessen the amount of light they receive. We must not get the notion that the more light the better for a plant, for plants can get too much light as well as too little; in tropical and semi-tropical countries plants have many ways of dodging or tempering the extreme light, see Lesson LXXII and especially the cross-section of a purslane leaf, Figure 117. 


\section{LESSON XI.}

\section{Adaptation to Light.}

The Shape of the Leaf-Blade.

Figure 15 is a leaf of a cut-leaved maple. Figure 12 shows leaves of the Norway maple. Go close up to the Norway maple and see it "as the squirrel sees it." Its branches are bare; now visit the cut-leaved tree; its branches are all cov-

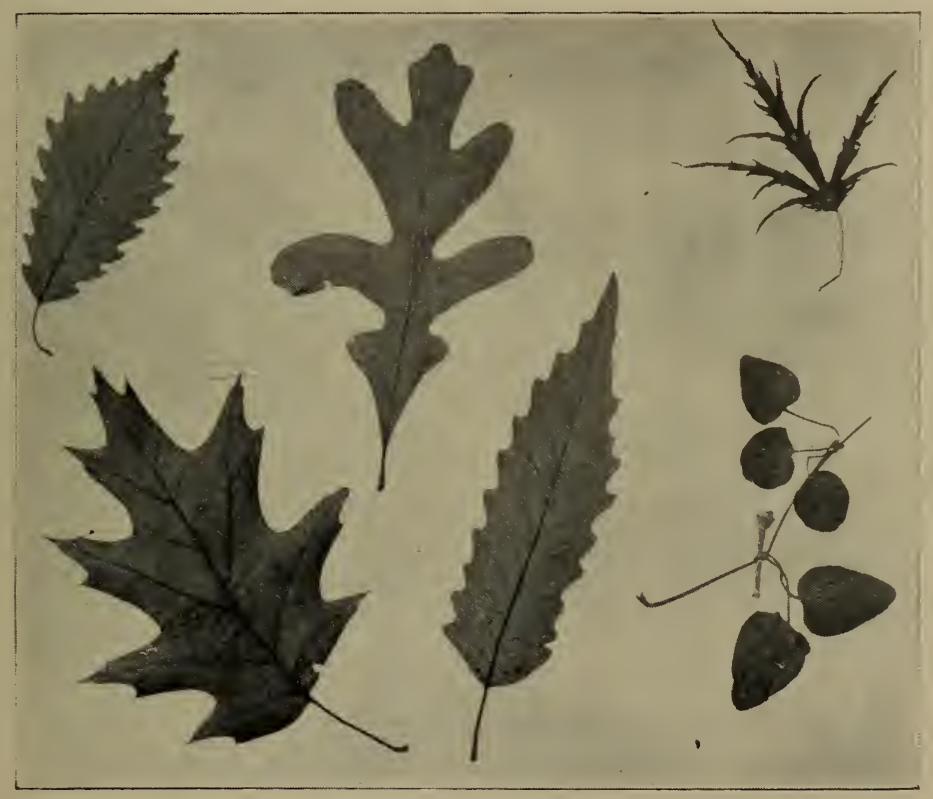

Fig. 13.

Fig. 16.

Fig. 14.

Fig. 17.
Fig. 15.

Fig. 18 .

Figs. 13 and 17 . Notched, pinnately veined leaves of yellow chestnut-oak. Fig. 14. Round-lobed leaf of white oak. Fig. 15. Cut-leaved maple leaf. Fig. 16. Awned, lobed leaf of red-oak. Fig. 18. Pinnately compound leaf of clematis.

ered with small branchlets, bearing many leaves. Is not the reason for this that the sunlight sifts through between the leaf-lobes of the cut-leaved maple, while the broad leaf 
of the Norway maple shades the main branches so that leaves cannot grow on their branchlets?

Exercise I: Estimate the number of leaves on a Norway maple and a cut-leaved maple of the same size. Have we not here on one tree a large number of leaves with small

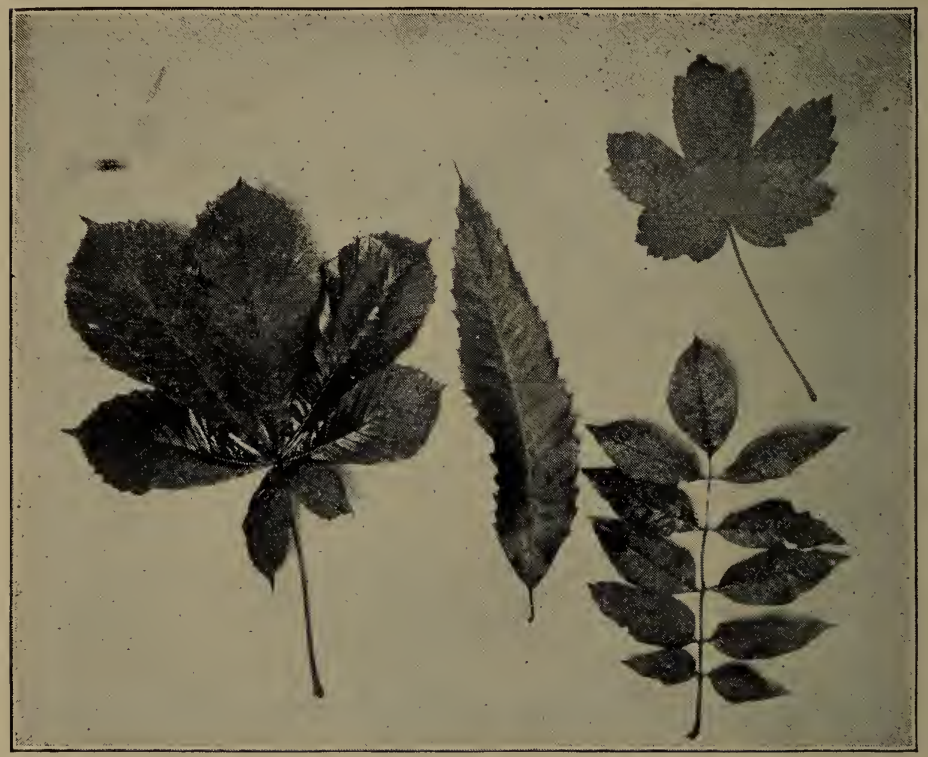

Fig. 19.

Fig. 20.

Fig. 21.

Fig. 22.

Fig. 19. Palmately compound leaf of horse-chestnut. Fig. 20. A chestnut leaf.

Fig. 21. The palmately lobed leaf of the sycamore-maple. Fig. 22. A mountain-ash, odd-pinnately compound.

working surface doing for one tree what a much smaller number of leaves with large blades do for another?

When the thermometer is 100 degrees in the shade, try the shade of these two trees. Try the shade of the locust, ash, walnut or Kentucky coffee tree in the same way; all of them have pinnately compound leaves somewhat like Figure 22. The light can filter through between the leaflets. 
The pine has needle-shaped leaves; has it more leaves than the sycamore? Try to estimate the number of leaves on trees about the same size. Try also the shade of the pine. The light can sift through between its needles to leaves below.

Exercise II: Find young trees, five to fifteen feet high,

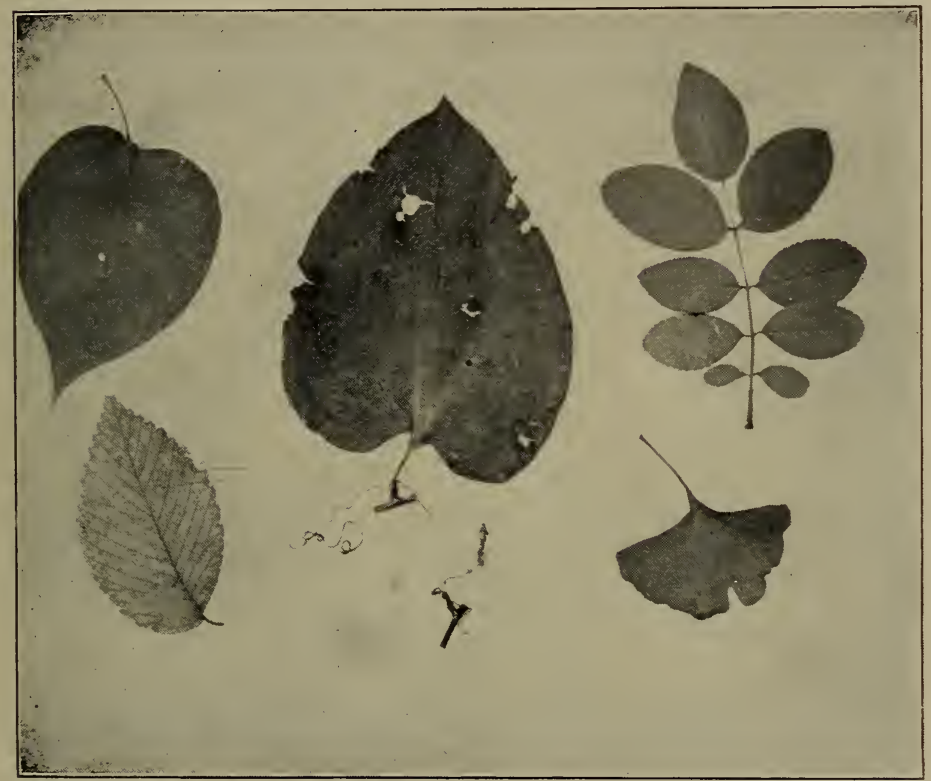

Fig. 23.

Fig. 26.

Fig. 24.

Fig. 25.

Fig. 27.

Fig. 23. Entire, heart-shaped leaf of lilac. Fig. 24. A greenbriar leaf showing stipules changed to tendrils. Fig. 25. A stipulate leaf of rose. Fig. 26. Oblique leaf of American elm. Fig. 27. Parallel-veined leaf of ginkgo.

growing in the shadow of a forest. Why have they larger leaves than similar undergrowth where the light is stronger? See if it is possible to make out a ratio between the size of the leaves and the intensity of the light; that is, that a larger leaf in a weaker light is required to do as much work as a smaller leaf in a stronger light. 


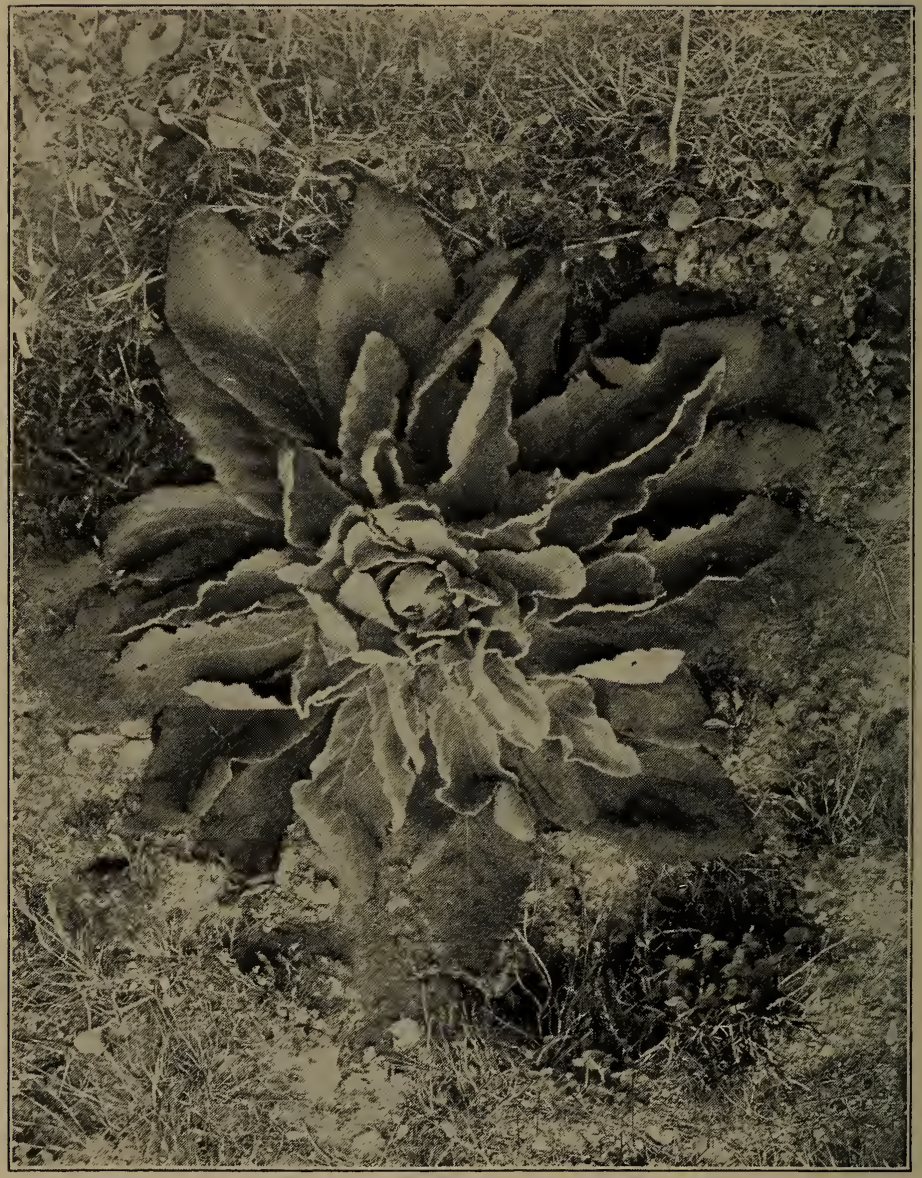

Fig. 28.

The rosette leaf-arrangement. A mullein of the first year 


\section{LESSON XII.}

\section{Adaptation to Light.}

\section{The Rosette Leaf-Arrangement.}

Figure 28 shows a mullein at the close of the first season of growth. Such a mullein can be found in October. Three things are to be noticed; each leaf grows out between two of a lower circle; the upper leaves are smaller than those below them so they do not shade them much; the upper do not lie flat as the lower do and for this reason shade the lower less. How many leaves in the mullein, Figure 28 , can get the light? How many in the mullein you are now stuciying and comparing with the cut? Draw accurately, as to direction of growth and size, the leaves of the mullein you have found. The mullein, thistle, cabbage and many other herbs are biennials; that is, they require two years to mature sceds. During the first season they store up the food which they will use the next in maturing the seed. A necessary part of the work of preparing the food stored in the root is done in the leaf, see Lessons XCII and XCIII. The October mullein is getting ready for the stalk and seeds of next year. Figure 54 shows the seed bearing mullein of the second year.

\section{LESSON XIII.}

\section{Adaptation to Light.}

\section{The Stem's Main Duty.}

The stem, (in the case of a tree, the trunk and branches, ) holds the leaves up to the light; this main duty imposes upon it the additional duty of bringing nourishment and moisturt up from the ground and of supporting the top againse 
storms. It may be noticed that trees grown in rich soil have much larger and taller trunks and branches than those grown in poor soil; oak forests in sand, as those at Oak Bluffs, Mass., are barely a third as high as those of our northern states. As one travels toward the north, trees become smaller and smaller until they at last trail beneath the snow. One notices the same thing in ascending a mountain; our prairie sunflowers in western Indiana and Illinois are fifteen feet high or more; as one goes west he sees

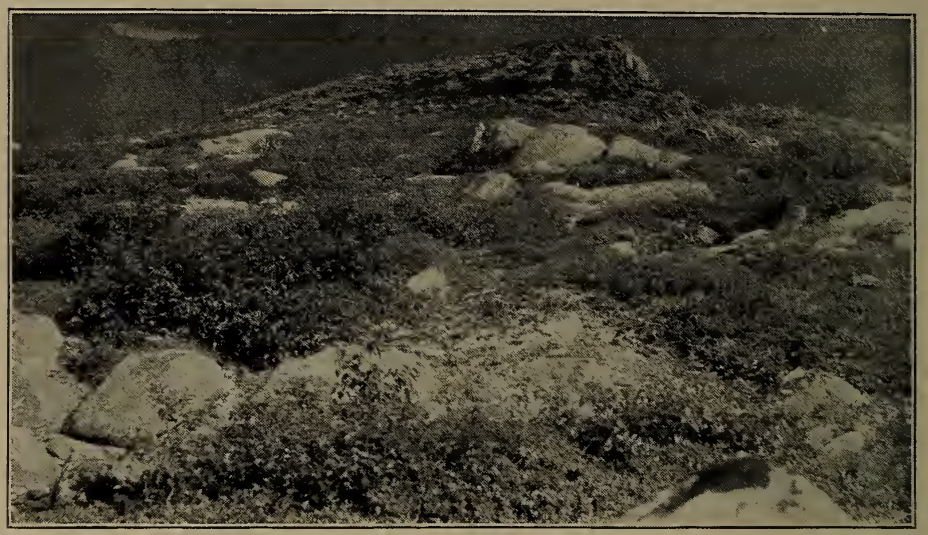

Fig. 29.

Birches on Mt. Katahdin. Photographed by Prof. J. F. Thompson.

them becoming lower and lower until at Denver they are three feet; as he ascends Clear Creek canon the same shortening goes on; ascending Gray's Peak one comes to brook plains carpeted from the melting snows on one side to the melting snows on the other with apparently stemless flowers, the prairie sunflower and its congeners from the plains. This seems to indicate that the stem is a great convenience under favorable conditions such as our rich soil affords, a necessity to be sure for large growth, but not for existence 
as"roots, leaves and flowers are. Varying conditions of soil and climate do not permit a plant to avail itself of the sunlight to the same measure, so the stem varies as its environment varies.

Exercise: Compare plants of the same species grown in different soils. When opportunity offers make the same observations while ascending a mountain.

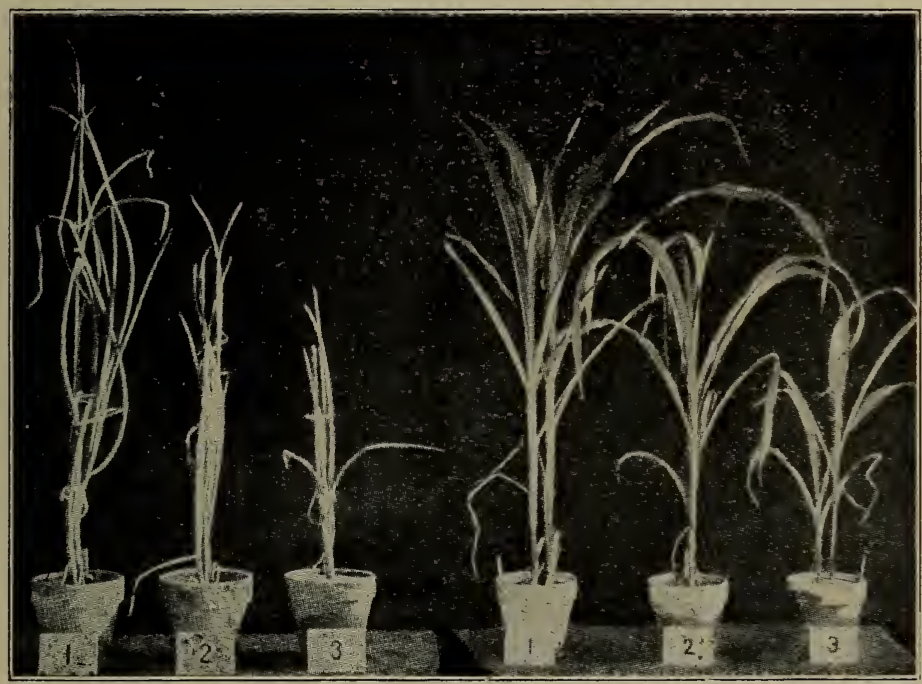

Fig. 30 .

Onions and corn growing in loam, clay, and sand to show influnece of soil. From the Proceedings of the Indiana Academy of Science for 1902, by Prof. H. B. Dormer.

Figure 29 shows birches growing on top of Mt Katahdin, Maine. They are not small because they are young, but because the climate compels them to be. The main stem has become a rootstock from which the dwarf branches grow.

Figure 30 shows on the left three onion plants, one grown in loam, one in clay and one in sand; on the right are three stalks of corn similarly grown. The effect of soil need hardly 
be commented upon. The conditions of moisture, temperature and light were the same for all.

Exercise: Try raising potted plants in different sois. Try the effects of various fertilizers on plants. The secret of variations giving the fine greenhouse plants is due sometimes wholly to the fertilizer.

\section{LESSON XIV.}

\section{Adaptation to Light.}

\section{The "Sleep" of Plants.}

It will be shown, Lesson XCIII, that plants utilize sunshine in their work by day. Stems and branches hold their leaves up to the light and each petiole grows so as best to bring its blade into proper relations to it. Figure 31 shows an Abutilon photographed on a sunny day at noon. Figure 32 shows the same plant in the same situation at 10:45 p. m. Every leaf droops. The day expanse was 14 inches; the right expanse, 9 inches.

Exercise: Grow squash, pumpkin, cucumber, etc., as potted plants and measure accurately the positions of their leafblades at midday and at midnight. The same measurements may be made on shrubs that grow in the yard. A good one to measure is redbud. Make also day and night examinations of bean and pea, growing in the garden. In the day time, every leaf is alert and adjusted to the light. Can it be that plants sleep and wake, work and rest?

What causes the leaves to assume these different posi- 
tions? We are accustomed to say that it is the stimulus of the light; but this Abutilon assumes the erect position before it recomes light. It begins to awaken about $4 \mathrm{a}$. $\mathrm{m}$. and

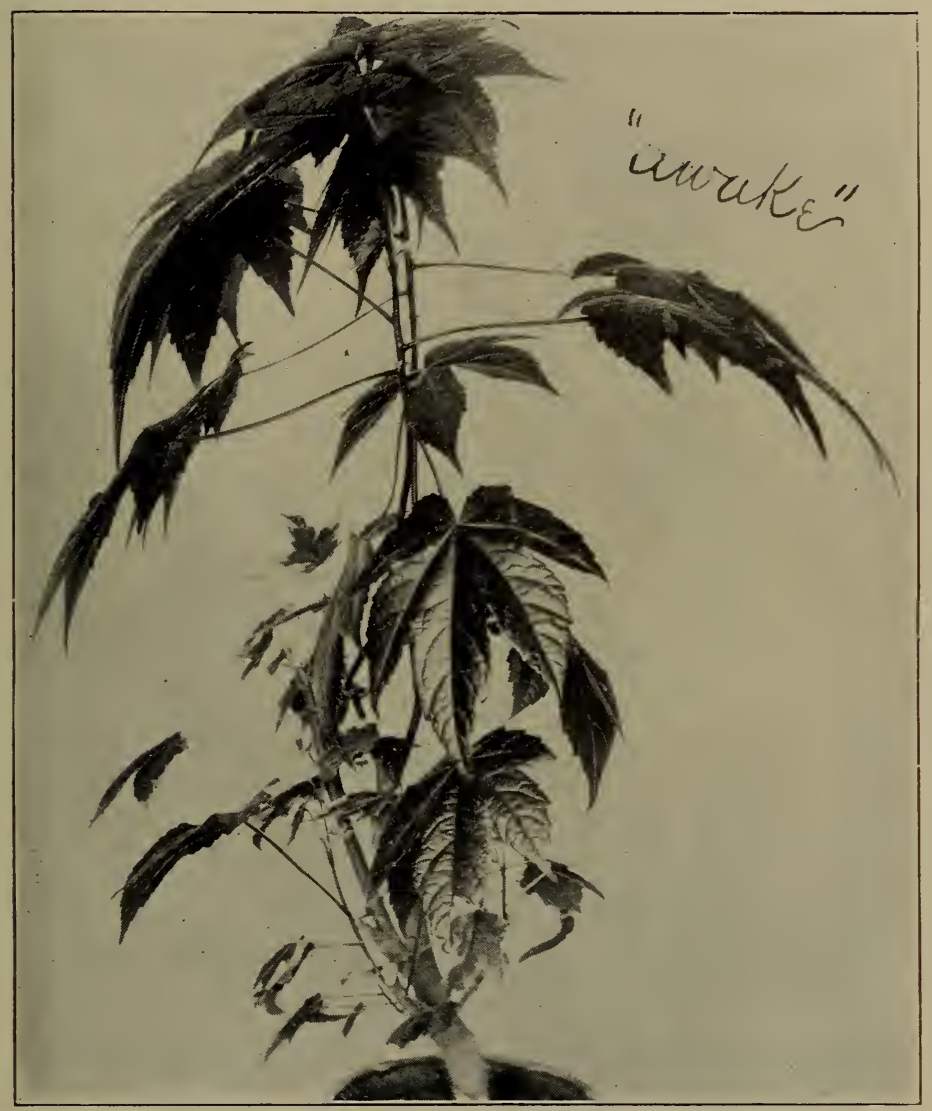

Fig. 31 .

Abutilon, photographed at noon.

is fully awake when it is light (January, 1903). It wakens up in a dark room into which no ray of light comes, at its usual waking hour. 
These night and day movements of plants are called nyctitropic; they may be studied to advantage in clover

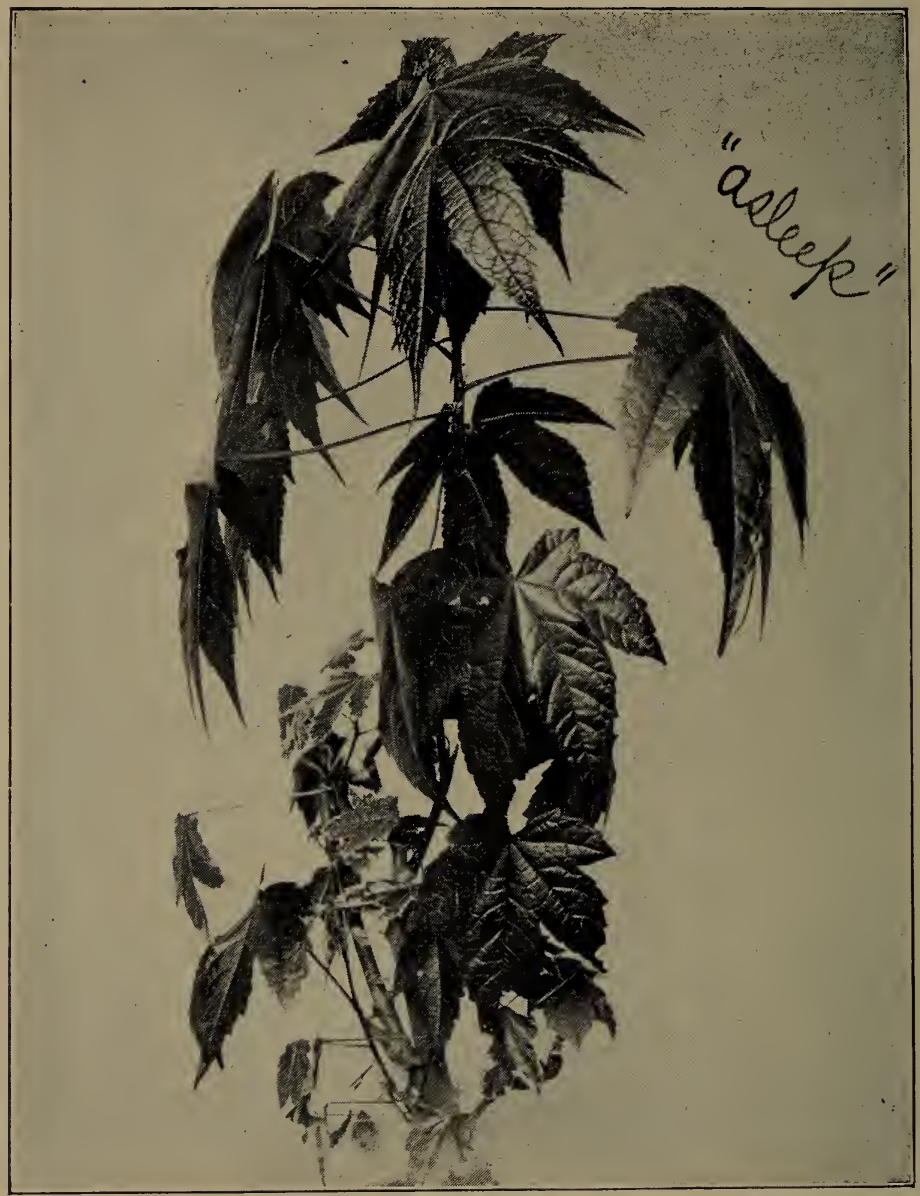

Fig. 32.

Abutilon, photographed at 10:30 p. m.

and Oxalis. In Oxalis the leaves fall from the horizontal position until they rest against the stem; in clover on the 
contrary two of the three rise and bring their upper faces together while the third leaf rises in such a manner as to cover the two somewhat.

Campbell says these movements are to diminish the radiating surface and prevent the loss of heat, but the Abutilon, clover and Oxalis all make these movements in a room that remains at the same temperature. Whether the action was at first caused by the alternation of light and darkness or by day and night changes of temperature or by both, the habit is so established that the movement is carried on, for a time at least, at a constant temperature and in total darkness.

Examine leaves also at midday on a very bright day and see if they respond to the stimuli and change their positions in the presence of too much light and heat as well as too little.

\section{LESSON XV.}

\section{Adaptation to Light.}

\section{The Leaf-Arrangement of the Beech Tree.}

An elm will do for this lesson as well. The leaf-arrangement and bud-arrangement, when no buds are suppressed, are the same for the same tree. The buds generally appear in the axils of the leaves, that is, just above the attachment of the leaves to the stem. It will be seen that the beech spray in full leaf is flat, that the leaves grow on opposite sides only; that there are two rows of leaves only on each branch; that consecutive leaves are 180 degrees apart; that if a string is passed through a beech branch from a leaf to those above it in order, the third leaf is over the first as shown in Figure 33. By this arrangement no leaf-blade can ever shade another on the same branch. For this reason they do not need long petioles to bring them to the light. Notice that they do not have long petioles. 
Test this proposition on every plant you can find: the petiole of a leaf has for its main duty the task of bringing the blade to the requisite amount of light.Compare Lesson IX

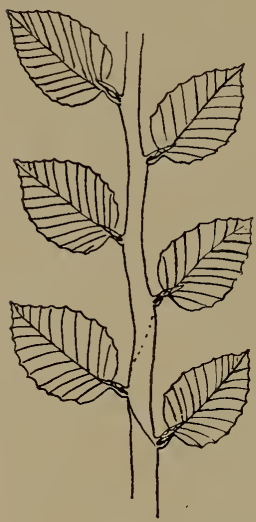

Fig. 33.

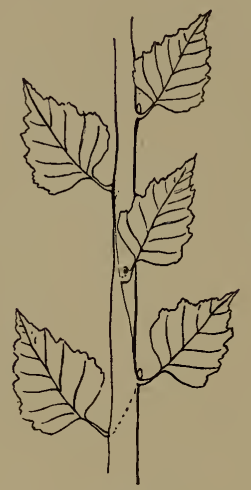

Fig. 34.

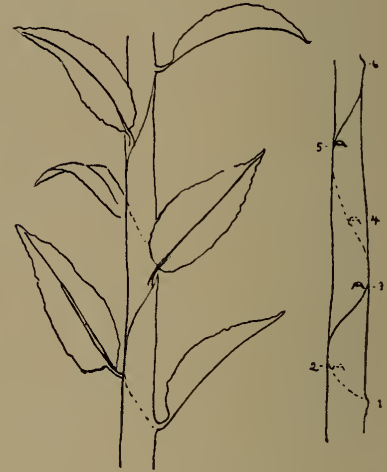

Fig. 35 .

Fig. 36.

Fig. 33. A two-ranked beech branch. Fig. 34. A three-ranked birch branch.

Fig. 35. A five-ranked apple branch. Fig. 36. A way to determine leaf-arrangement. Drawn by Miss Helen M. Fiske.

Exercise: Draw a beech or elm branch. The drawing should show for the purposes of this lesson that the petiole is very short and that the leaves are two-ranked.

\section{LESSON XVI.}

\section{Adaptation to Light.}

\section{Leaf-Arrangement.}

In previous lessons reference was made to the tworanked leaves of beech, the eight-ranked leaves of hedge and the five-ranked leaves of apple. It was necessary to do this in order to study the light adaptations.

Exercise I: Get straight young branches of elm, beech, 
mulberry, and hazelnut and compare them with Figure 33. This is the simplest of all leaf-arrangements. There are two leaves in one round; the leaves are 180 degrefs apart and there are two vertical rows on the stem. Notice now that the arrangement of the branches is the same on those trees; notice that the bud-arrangement is the same; that buds and 1 ranches are alike just above leaves; this rcsition of the

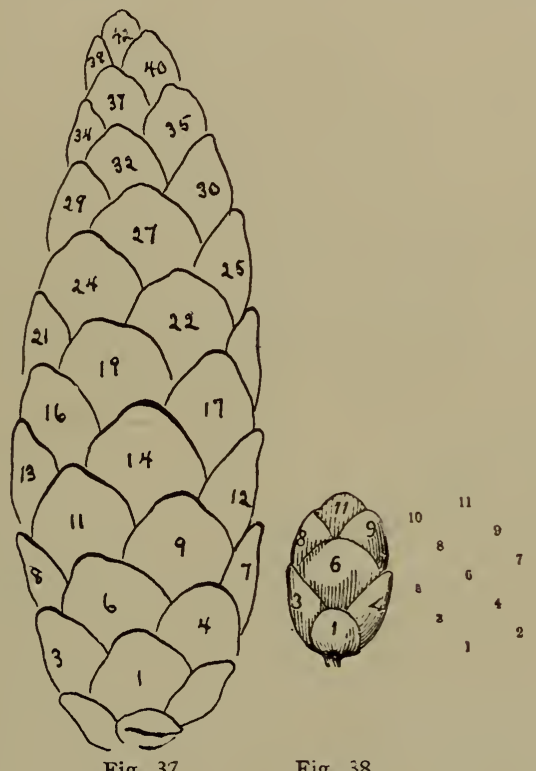

Fig. 37.

Fig. 38.

Fig. 37. A thirteen-ranked pine cone. After Gray.

Fig. 38. A fire-ranked tamarack cone. After Gray.

branches can be seen more easily on some branching annual like the clematis or ragweed.

Leaves, then, have positions in which they grow; so have buds and branches; this has reduced the study of disguised leaf forms to a science instead of a notion. Position is the determining element. It is important for the student to learn this. 
Exercise II. Get short, straight, young branches of birch and also some of the tall, rough, triangular sedge grasses; cut these off very close to the ground and examine

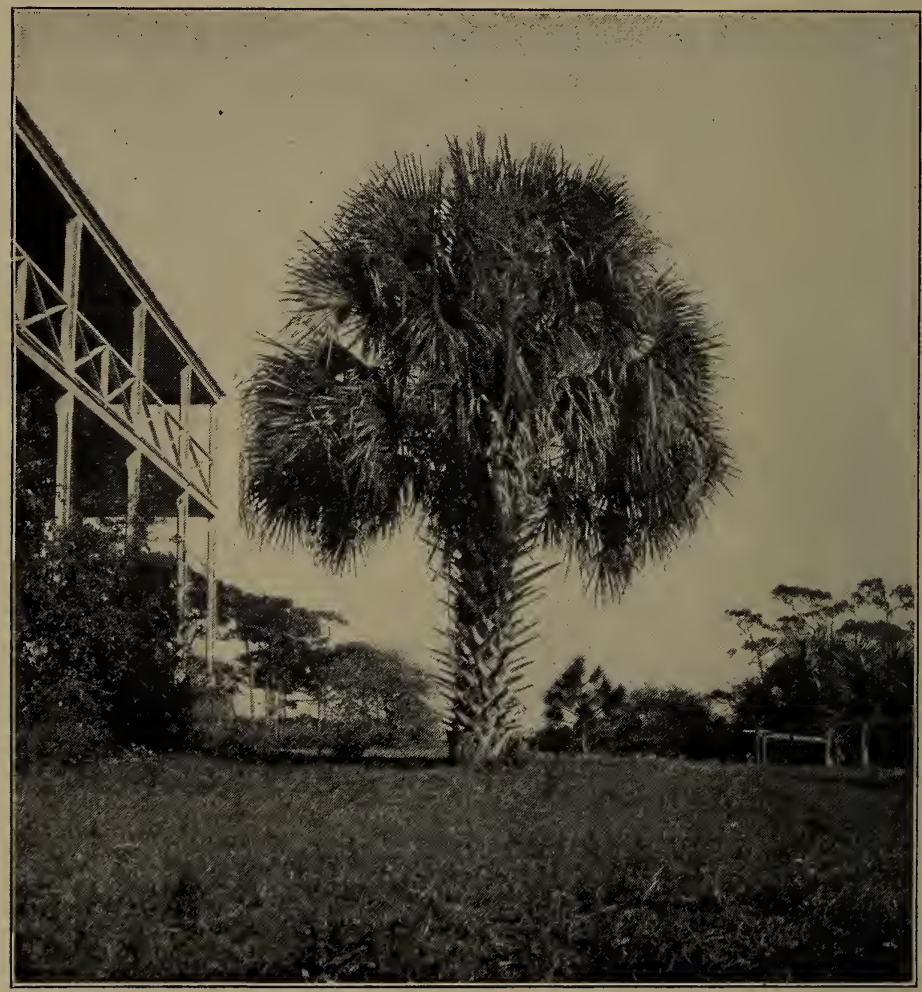

Fig. 39.

A cabbage-palm-Melbourne, Fla.

the sheathing leaves at the base. Compare their leaf-arrangement with Figure 34 . Notice that there are three leaves in a round, that any two consecutive leaves are therefore one-third of 360 degrees, or 120 degrees apart. This will be much more difficult than exercise I. If you 
fail try exercises III, IV and V first and then return to II.

Exercise III. Get straight water sprouts of peach, cherry, plum and quince and cones of the larch and tamarack. Compare them with Figures 35, 36 and 38. Pass a string as shown in the cut. Notice that the sixth leaf is over the first; that the string to reach the sixth must pass twice around the stem. There are then five leaves in two rounds; or the consecutive leaves are 2-5 of 360 degrees, that is 144 degrees apart.

Exercise IV. Get similar branches of hedge, holly and plantain and compare them with Figure 11, and make calculations as before. How many rounds does the thread make before reaching the leaf directly over the first? How many leaves does it pass? What is the angular distance between consecutive leaves? How many vertical rows are there on the stem?

Exercise V. Get a cone of white pine and make out the arrangement in Figure 37 and make calculations as before. Answer the questions for the white pine given at the close of Exercise IV.

Notice that all these different leaf-arrangements are so many ways plants have to accomplish the one purpose of getting their leaves to the light. Figure 39 is a cabbagepalm. What has its trunk to do with getting its leaves to the light? The long petioles of the leaves? The arrangement of the leaves? The frayed out ends of the leaves?

"Next to moisture, light is the most powerful external factor in giving shape to plants. Warmth sets the machinery of the plant in motion and regulates in the highest degree its development and activity but does not affect form. Light, as also water, exerts a commanding architectonic influence in the upbuilding of the plant body."-Schimper. Plant Geography as Influenced by Light. 


\section{LESSON XVII.}

\section{Pollination.}

\section{Self-Pollination.}

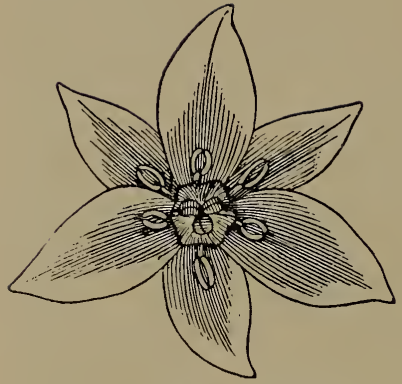

Fig. 4u.

A complete flower; three sepals, the smaller outer leaves; three petals, the longer inner leaves; six stamens and a pistil of three united carpels having three recurved stigmas. After Gray.
Figures 40 and 45 show flowers with sepals, petals, stamens and pistils. In Figure 40 the stigmas are recurved and at the center. Every one has seen the f owder, often yellow, which the stamens bear. Figure 41 and 42 show photographs of some of this dust taken with a microscope; the figures show the grains many times as large as they really are. These grains of powder are called pollen. It has often been shown that plants will not bear seeds unless this pollen falls on the stigma of the pistil. This process is called pollination. Figure 41 shows 2 pollenyrain, the wall of which has opened and the co itants of which are growing down through the top of the style toward the ovary.It does notcease to grow C'C $\mathrm{n}$ until it reaches the egg-cell of the ovary when one of the pollen nuclei unites with the egg-cell and fertilization is complete. When the stamens that furnish the pollen grow in the same flower with the stigma on which they fall, we call the process selfpollination. When the stamens grow in one flower and the stigma on which their pollen falls g ows in another flower, we call the process cross-pollination. Flowers which have both stamens and pistils are perfect flowers.

Exercise: Find a half dozen kinds of flowers that are perfect. Count the stamens and stigmas in each so as to b? 


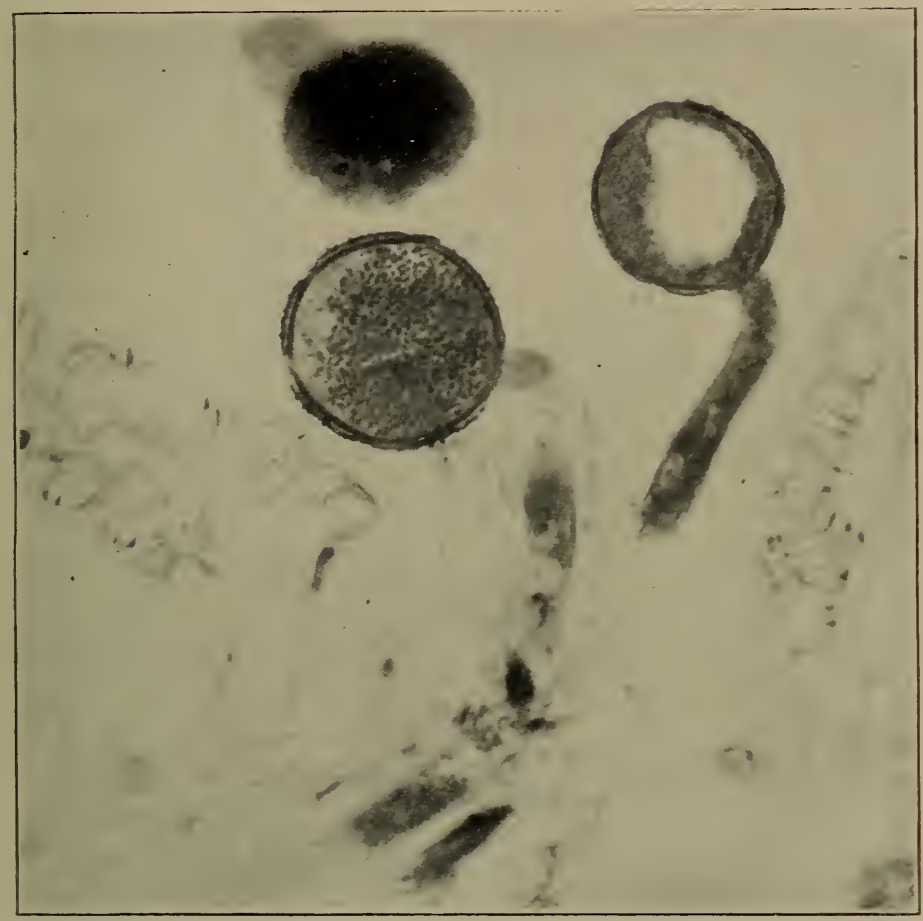

Fig. 41.

Two pollen-grains that have alighted on a stigma of purslane; their pollentubes are growing down toward the egg-cell in the ovary. From a slide by Mr. Virian Floyd. x 300 .

sure the flower has both and sketch them, showing just the right number.

\section{LESSON XVIII.}

\section{Pollination.}

Staminate and Pistillate Flowers. A Monoecions Species.

If a flower contains stamens but no pistils, we call it a staminate or sterile flower. There are many such flowers in 
a single tassel of corn. If a flower contains pistils but no stamens we call it a pistillate or fertile flower. The silks that corn bears where the ear is to be, are parts of fertile flowers.

We name all those plants that we think sufficiently re-

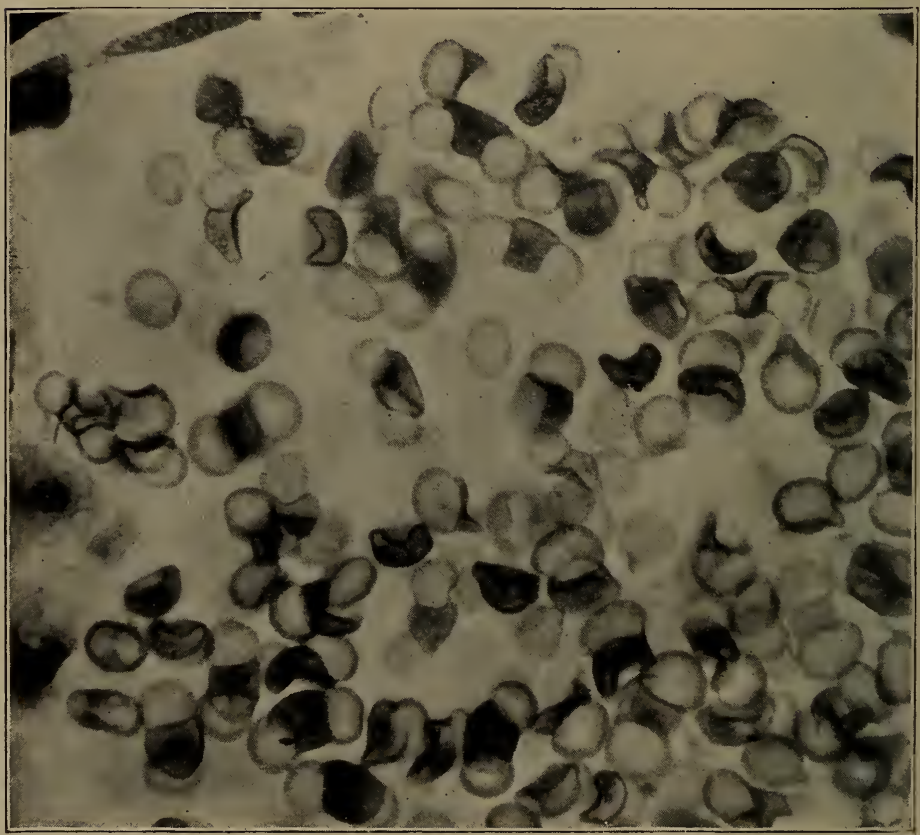

Fig. 42.

Pollen-grains of white pine with an air balloon at each end. $x$ by about 400 . semble each other to have descended from a single seed or from common parents, a species. Corn, the marsh-marigold and the red maple are examples of species. When the staminate flowers grow on one part of a plant and the pis-. tillate on another, as in the case of corn, we call the species a monoecious species. When the stamens grow on one plant and the stigmas on which the pollen falls grow on 
another, we have cross-pollination, in which different individuals take part as well as different flowers. Yellow and white corn will, as is well known, mix across a road; this is because pollen from the tassels, the stamen bearing flowers of one kind, falls on the stigmas of the other kind. It is said that it will not do to plant watermelons and pumpkins in the same patch; the pollen from the pumpkin blossoms will get on the stigmas of the watermelon blossoms and the melons will be ruined. Broomcorn and cane cannot, for similar reasons, be raised near each other. These are cases of cross-pollination between different species. Cross-pollination between individuals of the same species seems to result in stronger plants. Many experiments have been tried that show this; see Lesson XXVIII. We would be justified in concluding that it is so because nature has taken such pains to bring cross-pollination to pass.

\section{LESSON XIX.}

\section{Pollination.}

The Adrantage which the Monoecious Species Has.

The tassels containing many staminate flowers grow on the top of the corn stalk; the chances are that the pollen will be carried by the wind obliquely and that it will reach the pistil of some other stalk and so produce cross-pollination between flowers of two individuals. If the pollen grew in the same flower with the silks this would be far less probable. It may be said that the monoecious arrangement favors cross-pollination from plant to plant and is therefore a help. The ragweed furnishes another fine illustration of this. The sterile flowers grow in long racemes at the top of the weed. It is a habit some boys have to scrape up between 
their fingers the yellow dust and its receptacles from the sterile flowers. Where do the fertile flowers and seeds of the ragweed grow? At least they grow somewhere lower on the weed than the sterile flowers do. The wind carries the pollen everywhere and doubtless effects cross-pollination from plant to plant generally.

\section{LESSON XX}

\section{Pollination.}

\section{The Dioecious Species.}

It often happens, as in the case of the mulberry, that ail of the trees do not bear seeds. This may be because one tree bears only pistillate flowers and the other only staminate flowers. The first kind is said to be a fertile, pistillate or female tree, the second a sterile, staminate or male tree. A pistillate tree will only bear when there is a staminate tree somewhere near enough to send pollen to its stigmas.

Exercise: Find a mulberry tree that bears and see how far it is to a pollen bearing tree. It would manifestly aid the wind in bearing the pollen long distances if the pollengrains were winged. This is often the case. Figure 42 shows the winged pollen-grains of white pine.

Herodotus makes note of the fact that the Egyptians had a yearly festival, in which they went to the desert and brought sterile palm branches and waved them over the fertile trees they had planted along the Nile. By this means they could give all their space to the growing of trees that would bear. It would be interesting to know how they came by the knowledge that such action would cause fruit to grow, long before we knew the office of pollen in fruit production.

Exercise: See if box-elder is a dioecious species. Is red 
Cedar? Is Ailanthus? Is the Persimmon? Is any willow you know?

The pldin advantage of the dioecious arrangement is that cross-pollination is the only kind that can occur; but it seems to be a law that every advantage has its accompanying disadvantage; the disadvantage in this case is that only part of the trees can bear fruit.

\section{LESSON XXI.}

\section{Pollination.}

Flowers in whrch the Psitil Appears First.

Common plantain is a weed every one knows; it has a rosette of tough broar leaves from which it sends up a long spike of flowers. This spike blooms from the bottom up. In any given flower the pistils ripen before the stamens do; it is therefore entirely impossible that any stigma should receive pollen from a stamen in the same flower. Protogyny is the term we use to describe this arrangement; the word means pistils blooming first. This is one of many ways by which nature provides for cross-pollination. If the lowest flowers on any stalk are fertilized at all it must be with pollen from another plant; it is often coubtless true that higher stigmas receive pollen from other plants. That the ripe pistils are above the ripe stamens favors this. The growth of the plants in societics a'so favors it.

Some species of plantain may be found blooming all summer long. Sketch a spike when the ascending circle of protruding stigmas has reached the middle of the stalk with the circle of stamens below it. 


\section{LESSON XXII.}

\section{Pollination.}

Flowers in which the Anthers Appear First.

The fireweed, Epilobium, is not so common as the plantain. I have, however, seen it blooming in many parts of the country, late in August. Its time for blooming is given from July to September. It has a pink-shaped blossom with a reddish-purple color. It is some four feet high and very striking. Its anthers come out first, the stigma being bent quite out of the way, and discharge their pollen and wither; the pistil now becomes erect; the anthers of its own blossom having withered, only cross-pollination can occur; bees carry pollen from one flower to another and thus pro-

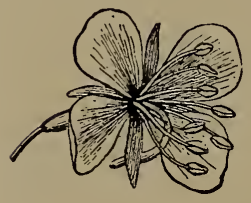

Fig. 43.

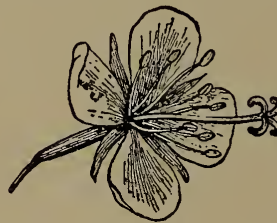

Fig. 44. duce cross-pollination. Fig. 43, after Gray, shows the ripe stamens and the recurved, unripe stigma. Figure 44 , also after Gray, shows Fig. 43. Fireweed blossom; stigma green and the erect ripe stigma
recurved, stamens ripe. Fig. 44. Fireweed; stigma ripe and erect; stamens withered. After Gray.

and withered stamens.

Figure 45 shows two blossoms of Amaryllis. The one on the right has ripe stigmas and withered stamens; the one on the left unripe, recurved stigmas and ripe stamens. Notice the white stigma quite below the anthers in front of a petal. Notice that it is not divided. Nine days later when its own stamens were wholly withered it had bent up to about their position so that an entering insect would brush it and its three stigmas were fully ripe and unfolded. The stamens being now mature in the left blossom are in a position to be brushed by an entering insect. 


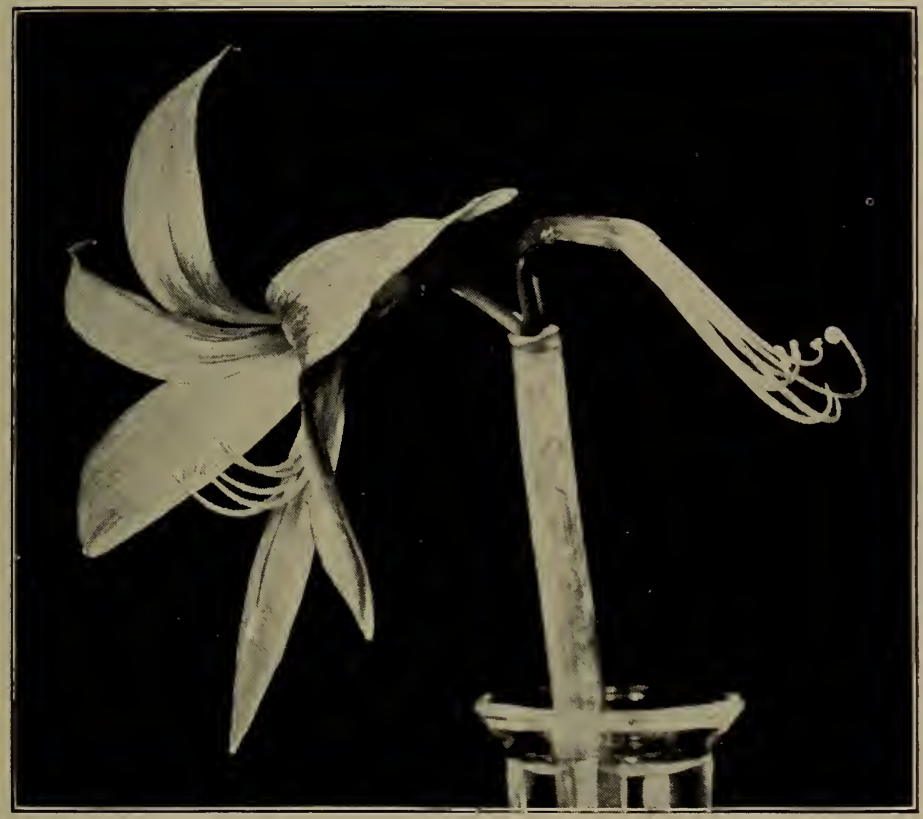

Fig. 4 j.

Two blossoms of Amaryllis; the stamens and pistils show the same thing as Figures 43 and 44. 


\section{LESSON XXIII.}

\section{Pollination.}

\section{Flowers and Insects. Bees.}

A fine beginning of the study of this relationship can be had by the careful study of the parts of a bean blossom; after which the visits of the bees to the blossoms must be

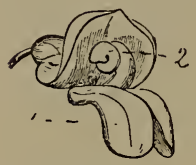

Fig. 46.

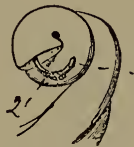

Fig. $4 \%$.

watched. The wings of the bean blossom (1),Figure 46 , furnish a landing place for the bee; it must land here in order to get Fig. 46. A bean blossom; 1, the wings on
which the bee lights. 2, the keel in which are the stamens and pistil. After Gray.

Fig. 47. Bean blossom. The weight of the bee on the wings causes the stigma 1 , and the hairy, pollen-laden style 2 , to come out of the keel.The stigma strikes the bee and picks up pollen from another flower. The blow makes its own pollen fall from the style cn the bee for the next flower he visits. After Gray.

the honey. The style, stigma and stamens are enclosed in the keel. The stamens early shed their pollen which lodges on the hairy style near the stigma, Figure 47. The weight of the bee on the wings presses the style and stigma out in such a manner that the stigma picks up pollen from the bee's body that came from another flower and at the same time the style scatters down on the bee its pollen to be carried to the stigma of the flower next visited.

Exercise: Press down on the wings of the bean blossom where the bee must light and watch the naked stigma and pollen-laden style come out. Cipher out the entire machinery and watch the bee's visit. .

\section{GLEICH UND GLEICH.}

"Ein Blumenglokchen

Vom Boden hervor,

War fruh gesprosset

In lieblichem Flur;

Dan kam ein Bieschen

Und naschte fein:

Die mussen wohl beide

Fur einander sein."
A tiny hare bell

In the meadow grew up

And hung out enchanting

Its little, olue cup;

A bee came and sipped

Of its sweets raintily;

They must for each other

Goethe. 


\section{LESSON XXIV.}

\section{Pollination.}

Flowers and Insects. Butterflies and Moths.

Adaptations between flowers and insects to produce crosspollination are very numerous and common. Some of them

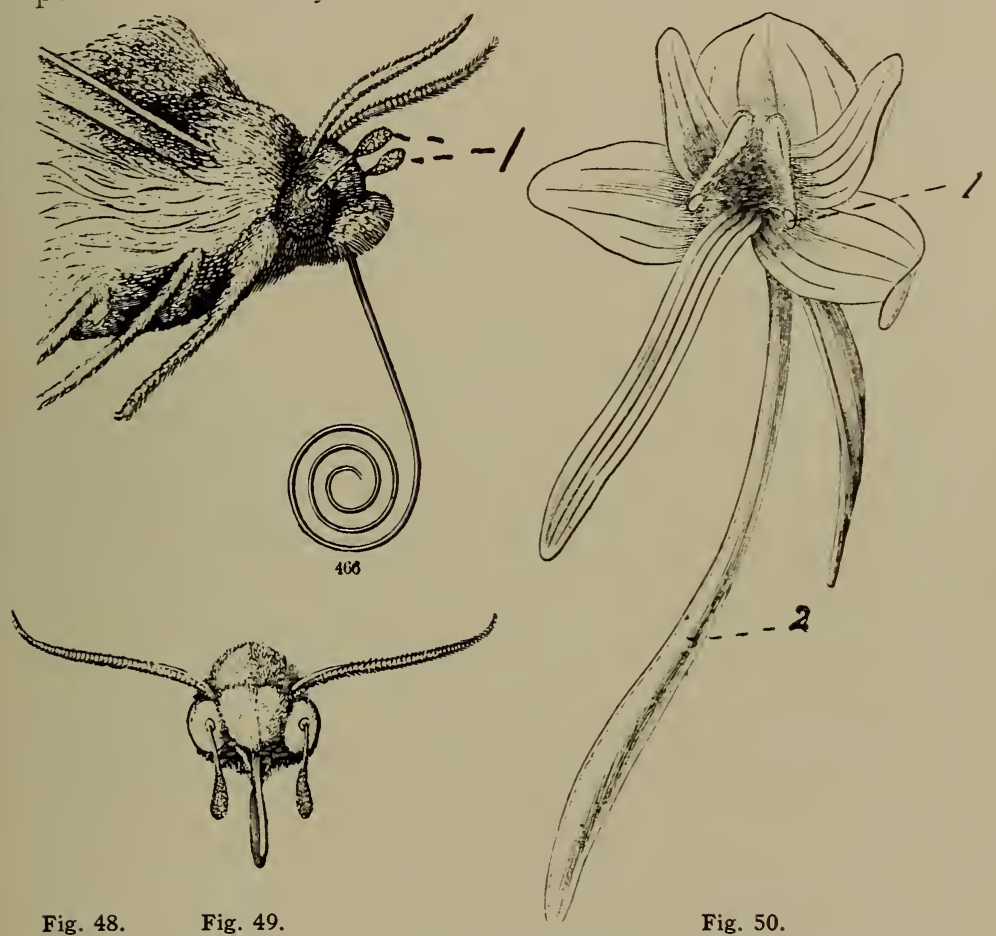

Fig. 48. Fig. 49.

Fig. 50 .

Fig. 48. Head of a moth. Its long tongue enables it to reach the nectary of an orchid shown in 2, Figure 50. Pollen masses 1, of Figure 50, adhere to the moth's eye by the disk; they are thus carried to the flowers subsequently visited. Fig. 49, the pollen masses by their gravity, turn down so as to reach the stigmas of flowers later visited. After Gray.

Fig. 50. An orchid blossom, after Gray. Its pollen mass adheres to the moth's eye by a glutinous disk, 1 , while the moth is getting nectar.

are very complex andinteresting, as, for instance, the lady'sslipper, which will only let a bee out of the "slipper" along a road that forces it to rub first against the stigma and pollin- 
ate it and then against the stamens and gather pollen for the next flower. The relations between certain other orchids and moths are as remarkable.

Figure 50 shows one of the orchids. The nectar is at the bottom of the long spur 2. The moth's tongue is just the instrument to reach it there. The opening into the nectary is so small that ants cannot enter; this is the case with many flowers; ants have no wings; they cannot fly from flower to flower and carry pollen for cross-pollination; it is therefore as necessary to keep ants out in some way as it is to attract bees, butterflies and moths.

Notice the flower again; at 1 there is a glutinous disk that carries many pollen-grains on a long stalk. These two disks are so situated that when the moth is taking nectar they will touch and adhere to its eyes as shown in Figure 48. Gravity then pulls them around to the position shown in Figure 49. When the moth visits succeeding flowers these will be thrust down to the concealed stigmas and cross-pollination will take place. Coordination is common between the various parts of one animal or plant, as for instance the tiger's claws and teeth go with the savage disposition; but here moth and flower fit each other like the nose and the spectacles. How came this fitness to pass? The way to study this question is to notice from year to year carefully all similar relationships and see if they do not finally fall into a system.

\section{LESSON XXV.}

Pollination.

Symbiosis._-"Reciprocity."

Bees get pollen and nectar for the hive from the flowers. 
Flowers get the inestimable advantages of cross-pollination from the bees. The relationship is one of mutual helpfulness. Symbiosis means life together. Butterflies and moths get nectar and pay for it with service in cross-pollination. The world of life is full of instances like this. The raspberry and cherry feed the bird and the bird plants their seeds in distant soils. The kingfisher digs the hole in

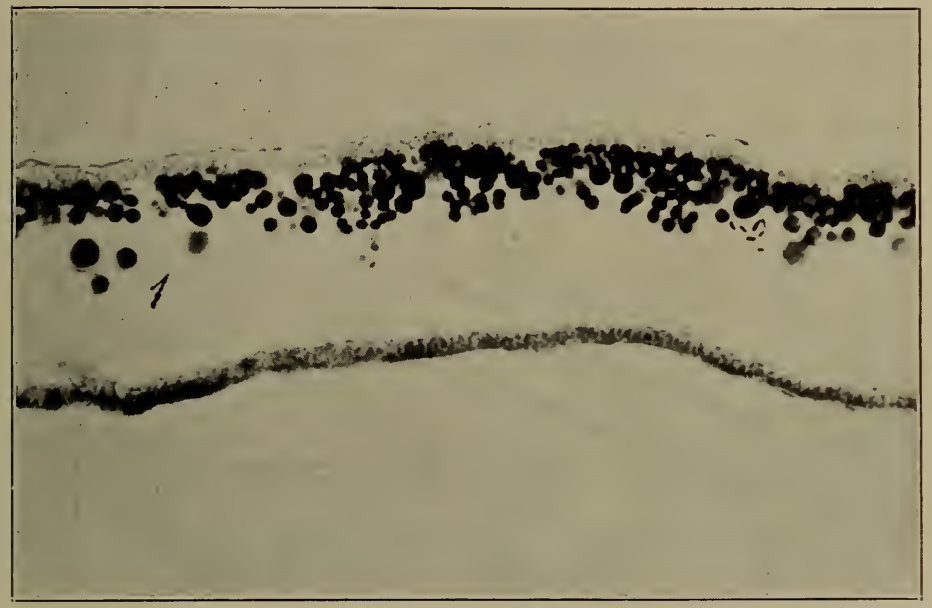

Fig. 51.

A cross-section of lichen, showing its compact upper and lower layers to prevent drying out; its inner reservoirs for moisture, 1 , and the symbiont within 2, the round, black cells. Their real color is green.

the bank and the bumble-bee has been known to occupy it with him and keep the small boys and other enemies away. The rattlesnake and the prairie-dog sometimes live together for similar reasons. The lichen has imprisoned a green plant between its leathery exteriors. The lichen holds the green plant up to the light, gives it support and protects it from the drought on rock or tree, while the green plant gathers food for both.

Exercise: Cut a lichen in two with a sharp knife or razor 
and notice the green strip between the two white ones. Figure 51 is a photograph of a cross-section of a lichen and its imprisoned alga. The alga has been taken from the lichen and reared separately; so it is an independent plant. What is the relationship between man and the domestic animals and plants? That is, are man and corn mutually helpful? Are men and horses?

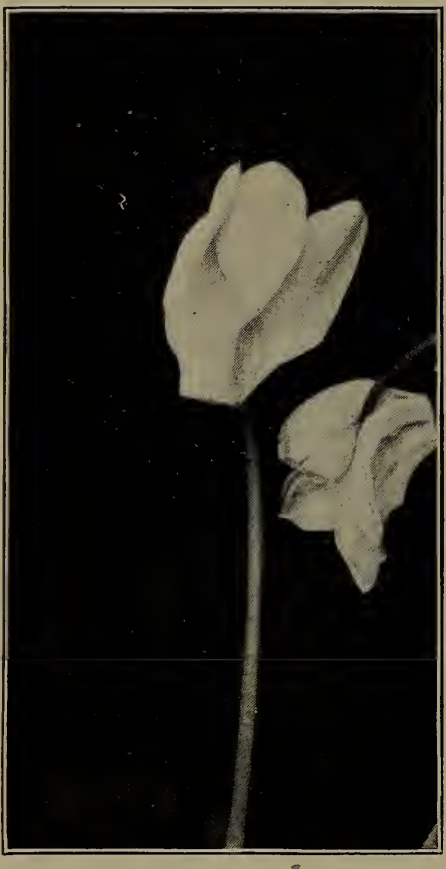

Fig. 52.

Cyclamen blossoms. The flower nods and the floral envelopes turn back up in such a manner that the entrance of ants or rain into the blossom is impossible. The lines in the petals shown in the blossom to the right were caused by eosin absorption. the nectar; sometimes the nectar is shut in and the door will

\section{Pollination.}

Flowers and Insects. How the Ants Are Kept Out.

One common way is given in Lesson XXIV. There are several other ways; the plant is sometimes surrounded by a water cup,- the teazel is an example. It sometimes is covered with bristly, downward pointing hairs in some part; sometimes these hairs are sticky and impede or even catch the ant; sometimes the plants are slick and the ant, in her efforts to stick on, pierces the skin of the plant and a viscid juice turns her back or catches her; sometimes the flowers are nodding and she can't crawi down to the edge of the corolla or calyx limb and safely turn and crawl back up to

\section{LESSON XXVI.}


not open except to the knock of the friendly bee.

Exercise: Be on the watch for all these methods of arresting the ant. See if you can find a smartweed that grows both on land and in water, having a water cup to keep ants away when it grows out of the water, which it leaves off when it grows in water. Read chapter III of Sir John Lubbock's "Ants, Bees and Wasps."

\section{LESSON XXVII.}

\section{Pollination.}

Flowers That Never Open.

Pollination sometimes occurs in a closed flower. This must always be self-pollination. The anthers that furnish the pollen and the stigma on which it lodges must belong to the same flower.

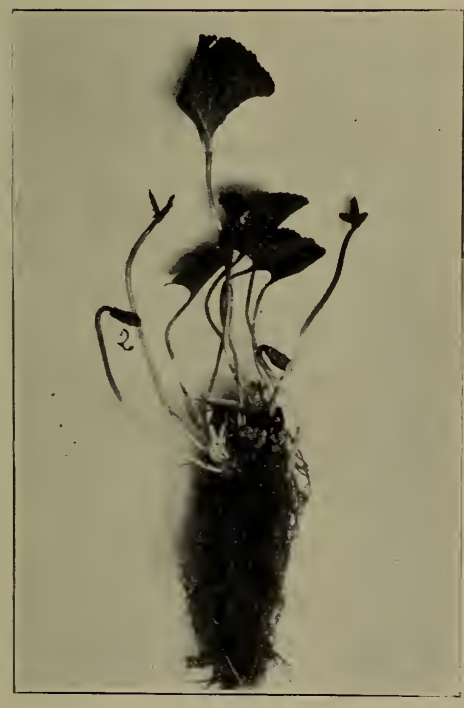

Fig. 53.

A violet plant dug in December Large pods of cleistogamic flowers, 2 , and pods of other ordinary flowers opened, 1.
Exercise: In the spring, examine every sort of violet that you can find, especially those that seem to have no stems; you will find a second kind of blossom concealed by the leares hard to find, but which bears nevertheless, more seeds than the flowers you have always known, Figure 53. These blossoms never open. There are flowers belonging to sixty different genera that are self-pollinated without opening. Cleistogamy is the name given to self-pollination in closed flowers. 
Some of the advantages of cleistogamy are: 1. Pollination is sure to occur. 2. It is not necessary for the flower to provide so much pollen. A cleistogamic flower grows some 400 grains of pollen; flowers which depend on insects to carry their pollen produce many times 400 and other kinds of plants yet to be described, see Lesson XXX, so many that the number can be estimated, not understood. Here, as elsewhere, advantage and disadvantage are balanced. The cleistogamic plants are weak. It is believed that they lack a factor that is necessary to their higher development. For some unknown reason, copulating cells from individuals of a species diverse in their origin give a strength and variety not otherwise to be had. Many simple plants and animals reproduce by division of the parent; but these do not improve; they live on and on at one dead level. Some eggs will grow into new individuals without fertilization; we call the process parthenogenesis, but the parthenogenetic species does not improve from generation to generation. A capital exercise for any one provided with a microscope would be, to estimate the number of pollen-grains in a cleistogamic flower of violet, an anemophilous flower like pine and an entomophilous flower like clover.

\section{LESSON XXVIII.}

\section{Pollination.}

Results of Experiments in Cross and Self-Pollination Plants of the Same Species.

Darwin raised 73 morning-glory plants from seeds produced by cross-pollination and in the very same soil 73 plants from seeds produced by self-pollination; these sets of 73 plants both belonged to ten generations. The height of the first 73 was to the height of the second 73 as 100 to 77 . So the crossing made stronger plants. 
His crossed and not crossed plants of the ninth generation bore seed by weight as 100 to 61 . These experiments confirm what we should expect from the fact that nature takes such pains to produce crosses and the further fact that crossing actually takes place among all higher plants.

Exercise: Cut the tassels from a few hills of corn before it ripens so that you can be sure cross-pollination from plant to plant, must occur. Dust the pollen from its own tassel on the silks of a few other stalks in the same row growing cloce by and see which makes the hest corn.

\section{LESSON XXIX.}

\section{Pollination.}

Why. Flowers Are Showy. Entomorhlous Plants.

The word entomophilous means insect-loving. It is applied to all those plants that depend on insects to carry their pollen. Such plants have bright colored flowers. Examples are red clover, white clover, morning-glory, hollyhock, snapdragon, Catalpa, etc., all showy flowered plints, ali jients the tlowers of which attirict general attention. It is beiieved that they are showy in order that the insects may see them. Why should tliey provide pollen and nectar for the insects and then not inform the insects in some way where they are? The odor of the flower serves the same purpose; a single flower might grow where the bee could not see it; in this case the odor alone tells the tale. We learned in Lesson XXVII that flowers that never open are inconspicuous. They are so inconspicuous that although they grow on our well known and universally loved violets, very few people indeed ever saw them. No doubt it is greatly to the advantage of flowers that do not depend on insects to help them to be inconspicuous. 
Exercise. Keep a list all summer long of the plants you see visited by insects. See if you can find out how it is necessary for the insect to become covered with the pollen and, also, to brush it on the stigmas of the flowers they afterward visit.

\section{LESSON XXX.}

\section{Pollination.}

Why Trees Have Not Showy Flowers. Anemophilous Plants.

The word anemophilous means wind-loving. It is applied to all those plants that depend on the wind to carry their pollen. This includes most of the forest trees north of the Ohio river. Most people do not know that our beeches, oaks, hickories and pines, etc., ever bloom at all, but if we examine them in the spring we shall find that they produce countless millions of pollen-grains; enough, so that a single tree can give them to the wind and fill all the air for long distances. The trees are tall; they can take advantage of the wind as low herbs cannot. It is a considerable tax on a plant to produce large, showy blossoms. Why should they do this when they have a perfectly adequate way to get all done that insects could do?

Exercise: Make a list of anemophilous plants. You may at first write in this list all plants with inconspicuous flowers, then notice to see whether bees visit them and if they do, note this fact. You cannot learn too soon that all our distinctions and cividing lines are artificial and for our convenience. You can not help observing, if you look, that many plants are crossed both by wind and insects and that self-pollination often occurs by the agency of both 
insects and wind and also in the very same plants without the agency of either of them. Let apparent inconsistencies be an incentive to you to look again. Sooner or later you will find that the sum total of the influence of wind and insect is to produce cross-pollination.

\section{LESSON XXXI.}

\section{Adaptation to Climate.}

\section{Storms.}

Stand by the window and watch a tree when the fiercest storm is on; see how trunk and branches and leaves, if there are any, yield to the storm. Where is the strain greatest? Is it not just at the ground? And yet is not this just the place where a sound tree never breaks? Did you ever try to split a stump? When the sound tree must fall does it not always break a few feet above the ground or else blow up by the roots? How does it come that the strongest place in a tree is the place of greatest strain and danger? Watch a very small tree, only two or three years old, in a storm. Does it not yield to the strain, even to the extent of bending over to the earth sometimes? Would this not have a tendency to twist the grain at the ground and make the grown tree stronger there? The storm then strengthens most where it threatens most.

Try to split a tree that has grown for a long time on the edge of a forest on the windward side and another that has grown in the middle of the forest; which splits the more easily? Why?

In parts of Europe, large areas are planted in trees. Hills and mountains are kept covered in this way by forests. As one ascends the Brocken he sees every few hundred feet, a 
small, fenced area. Trees are being sprouted in these to te planted out subsequently at the same altitude. They are raised from the start, subject to the same tempests, rairs and temperature that will surround them when they are trees, and in the same kind of soil.

\section{LESSON XXXII.}

\section{Adaptation to Climate.}

Annual Herbs.

In the northern United States, the growing season is practically between March and November. During the winter the temperature may fall to 20 degrees or more below zero. Most indigenous plants have habits which especialiy adapt them to this. Consider a tender herb like the rasweed; as winter approaches, it must cover itself with a clotting that can resist this cold and the accompanying wet, or die. I presume most of us think it dies, but that is not quite the case. It selects a small part of itself which we call the seed, to which it gives a covering adequate to withstand all the exigercies of winter and keep the embryo within alive. To have protected its entire body or even the main part of it would have been very expensive and, although some plants do this, if all plants did it we would have to have far fewer plants for there would not be room for them in the world.

One way then to meet the conditions of winter is to reduce life to the compass of the embryo and wrap it up securely with the food necessary to start it in the spring.

The beans we eat, the corn, the wheat, contain an embryo in every grain. Every one of them is a plant reduced to its winter condition.

Exercise: Make a list of fifty plants that live through 
the winter in their seeds only. In making this list, you must know from careful examination that the root as well as the top, dies. While this is true of the mullein or thistle that bears seed, it is not true of all mulleins or thistles.

\section{LESSON XXXIII.}

\section{Adaptation to Climate.}

\section{Biennial Herbs.}

A biennial plant is a plant that lives for two years only; that requires two years to bear seed. The root in all cases survives the first winter and the seed the second. The thistle, mullein, dandelion, turnip and cabbage are examples. The mullein does not grow a long stem the first year. This is an adaptation to the winter it must pass. It grows flat on the ground, Figure 28, and has a thick covering of branched hairs. These may serve to temper the light of the sun; to hold dampness away from the surface of the leaf so that when it freezes it makes a cloak to keep the leaf warmer than it would be if naked, to check transpiration, or to protect the mullein from enemies that would otherwise eat it. The chief adaptations of the wild biennials like the mullein and thistle, to climate are that they grow only a short stem the first year, and they shrink to the dimensions of seeds the second.

Exercise: Make a list of biennial herbs. Watch marked plants and see that they die when they seed at the end of the second year. Figure 54 shows a two-year-old mullein at seeding time. Compare it with Figure 28. 


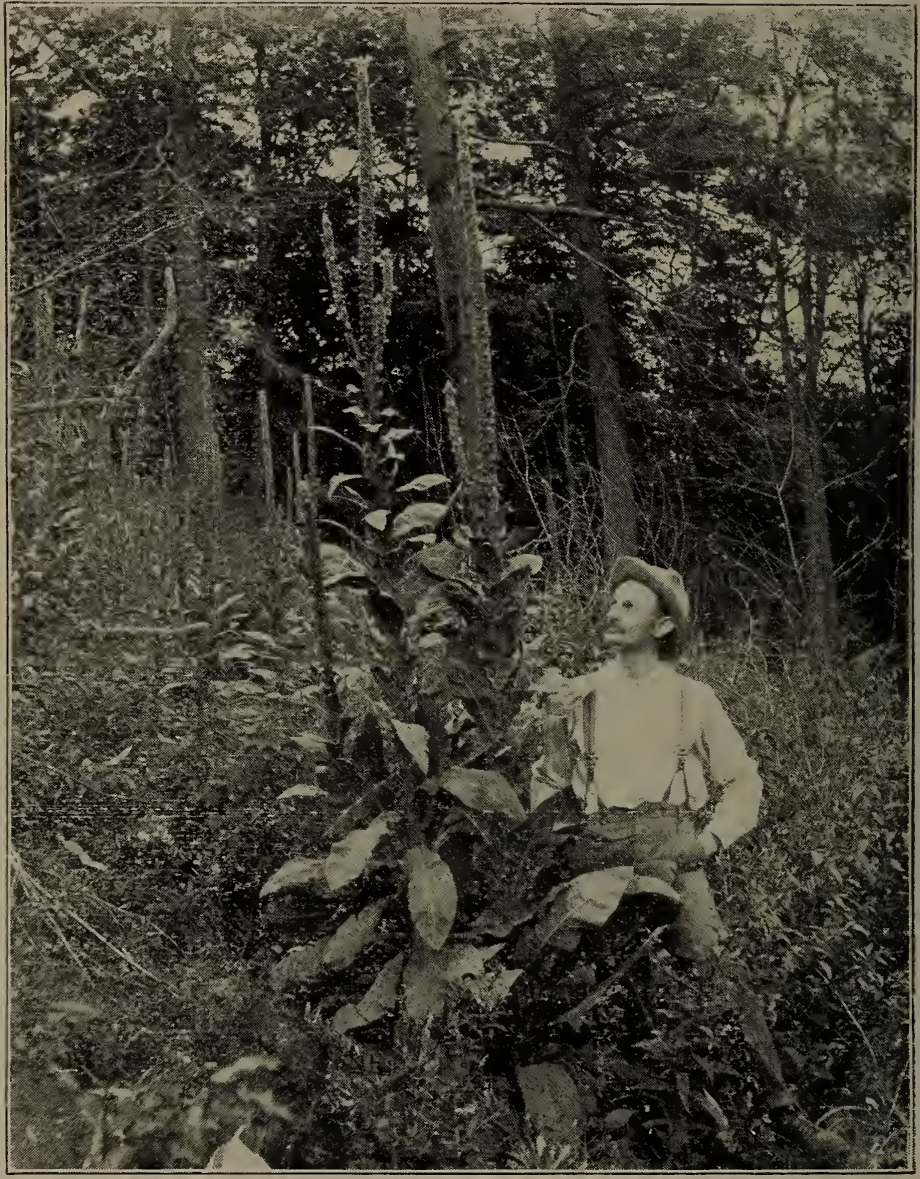

Fig. 54 .

A two-year-old seed-bearing mullein. Photographed by Prof. J. F. Thompson. 


\section{LESSON XXXIV.}

Adaptation to Climate.

\section{Perennial Herbs. Solomon's-Seal.}

You must know this intercsting plant if you do not. Figure 55 shows the underground stem with its peculiar seals, the places where the plant grew in previous years, and a terminal bud. The seals mark the place from which the

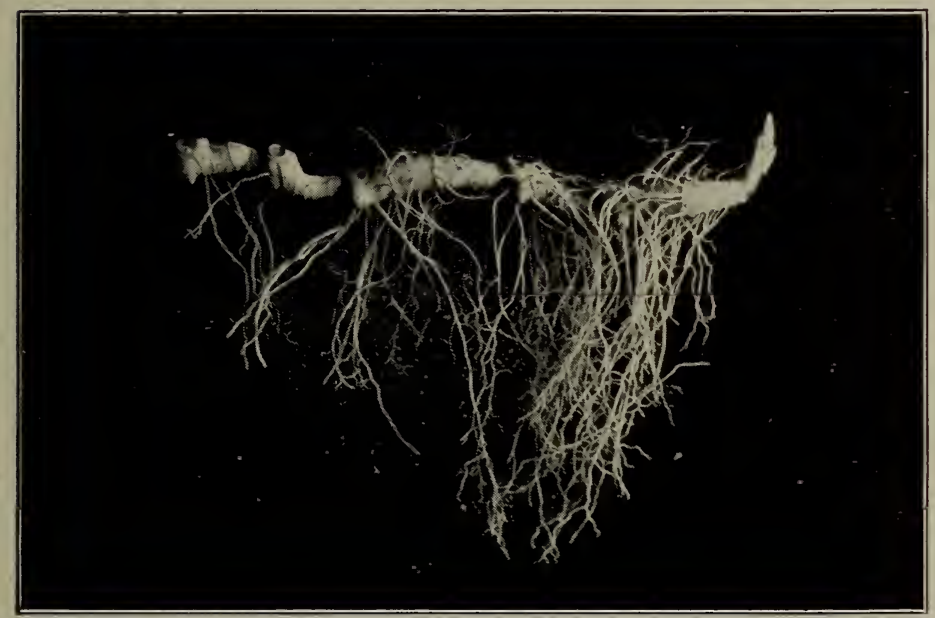

Fig. 55.

Underground stem of Solomon's-seal. The scars or "seals" are shown above where the above-ground stem grew one, two, three and four years ago.

aerial stem broke off last year and for the three years before. The root-stock is dying at the left. Its adaptation to winter manifestly is that it dies down to the ground at its approach and lives only in its underground stem and its seeds.

Exercise: Make as long a list as you can of plants in your vicinity that live through the winter by dying down 
to the ground only; it may help a little to ask, do ferns do this? Does bloodroot do it? Does blue-grass?

\section{LESSON XXXV.}

\section{Adaptation to Climate.}

\section{Deciduous Forests.}

The falling of the leaves in autumn is one of nature's great phenomena. To one born in the tropics, where verd-

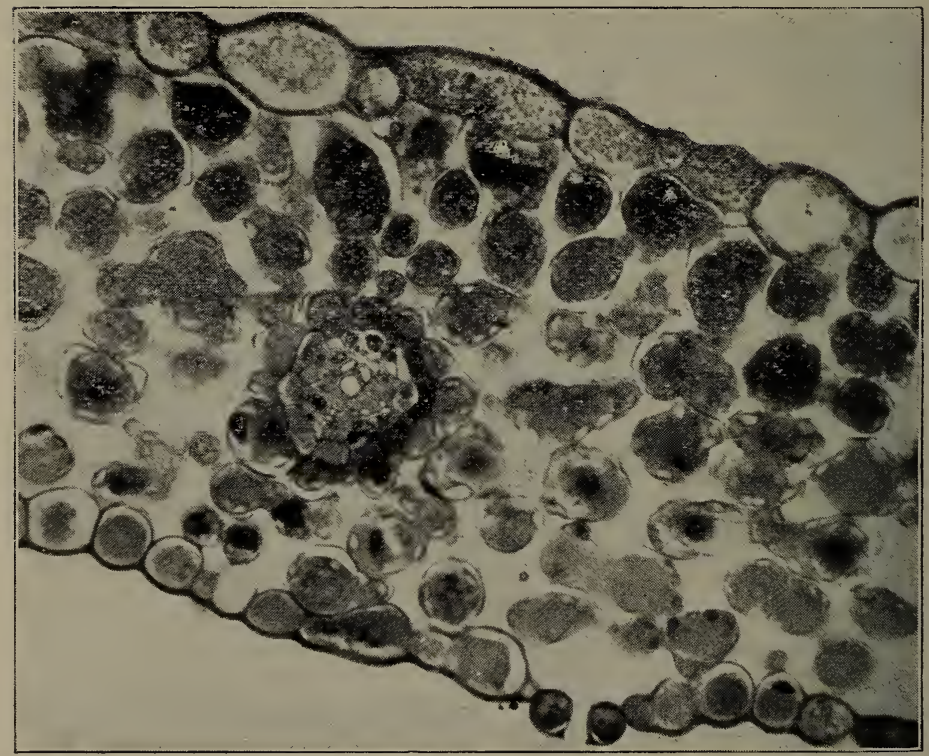

Fig. 56.

A cross-section of a deciduous leaf, a fern leaf; a stoma is shown open below. All the cells between the two layers of epidermis are working cells as their chlorophyll granules show. $x$ by about 200 .

ure is perennial, nothing is more striking. We are used to it and the strange thing for us would be for them not to fall. 
The falling of the leaves is a preparation for, an adaptation to winter.

Two choices are open to a tree: one is to so cloak its leaf surface that it can resist the cold of winter; the other is to shed its leaves. Each plan has its advantages and disadvantages; each has been followed by successful species. The sycamore saves itself the trouble and expense of protecting its leaves by shedding them; but when spring comes, it must spend many days of its precious time in getting its leaves back again ready for work. Figure 56 is a crosssection of a leaf that perishes as winter approaches; notice how thin is the outside protecting envelope. One of the stomata for admitting air is shown, open below. All the cells between the upper and lower layer are working cells. They are supplied with sap by means of the leaf's veins, one of which is shown near the middle of the section.

Exercise: Collect a half dozen different kinds of evergreen and as many deciduous leaves and see which will tear the easier.

\section{LESSON XXXVI.}

\section{Adaptation to Climate.}

\section{Evergreen Leaves.}

The pine has taken the second plan, mentioned in the last lesson: it protects its working cells. Notice again, how tough its leaves are. Find out anew that its outside covering is tougher than that of the leaves of deciduous trees. Figure 57 is a cross-section of the half of a leaf of the Scotch pine. You can tell this tree because it has reddish branches: it has leaves about three inches long and two in a bundle. Its leaves are covered with a white powdery substance and have a grayish green appearance. Notice how thick are the 
walls of the outside row of cells and also of the cells next to it except in the places where the leaf mouths for the admission of air are. Notice that this second layer is three cells thick at the corners. It would be difficult to find anything more remarkable in its adaptations, its fitness, than the pine leaf is. The cells from the protecting outside layers

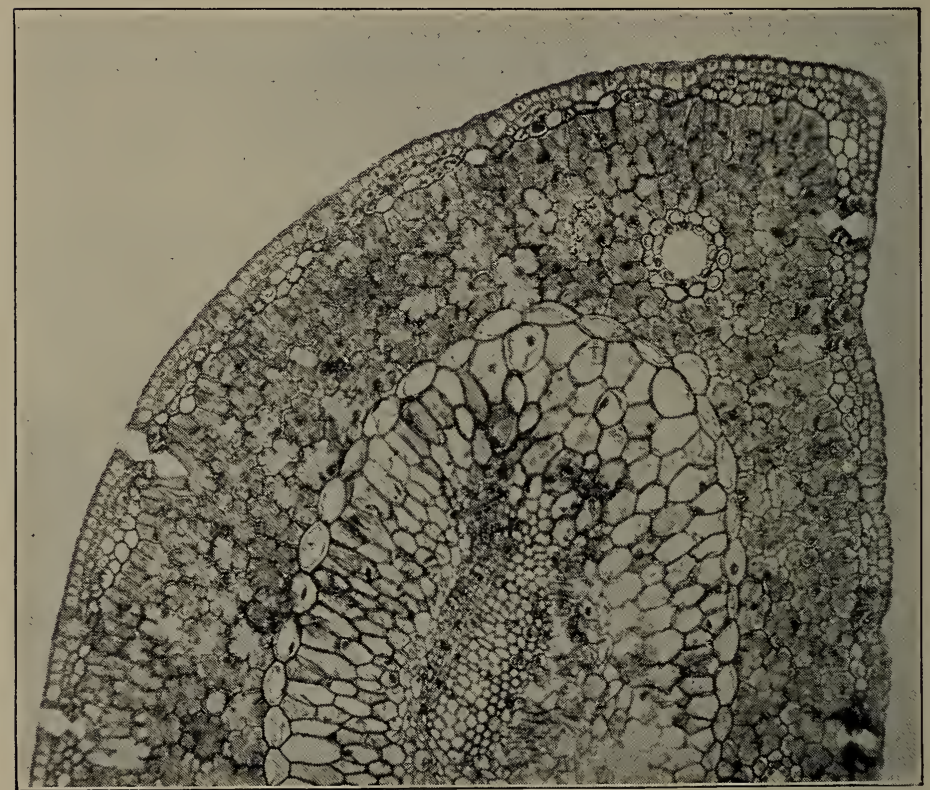

Fig. 57.

A cross-section of pine leaf. It shows from without in, 1, a thick walled epidermis; 2 , a thick walled hypodermis, both pierced by the stomata; 3 , chlorophyllbearing cells, to be known by their infolded wal s. They contain a resin duct, near the corner; a chain of bundle-sheath cells, 5, surrounding a fibro-vascular bundle. $\mathrm{x}$ by about 100 .

to the large empty row, the bundle-sheath, are working cells; they contain the green of the leaf, called chlorophyll. These green granules require surface positions on the cell wall in order to work. The cells have their walls infolded to increase the surface to which the chlorophyll granules 
may cling. These cells of the pine are packed very close together in pavements one akove another throughout the length of the leaf, with a slight sface between for air, in

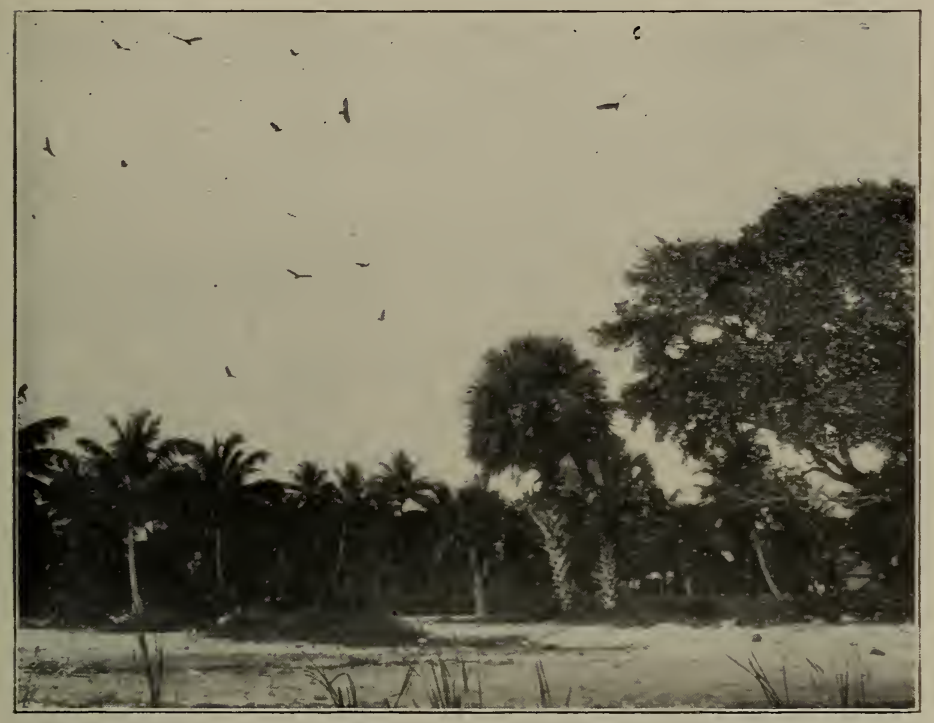

F.g. 58 .

An evergreen forest.

order to save space, so precious because it must be protected, at such cost to the tree. Figure 58 shows an evergreen forest. It and Figure 3 are December pictures; the one a Florida and the other an Indiana landscape.

\section{LESSON XXXVII.}

\section{Adaptation to Climate.}

Buds.

It seems to us that buds, as we see them in winter, are necessary to trees; that they are to be expected; a matter of 
course; so they are in our climate; the tender, growing points of a tree must be protected against the rigors of winter. There is no reason for such buds, and there are none, where there is little or no change of climate.

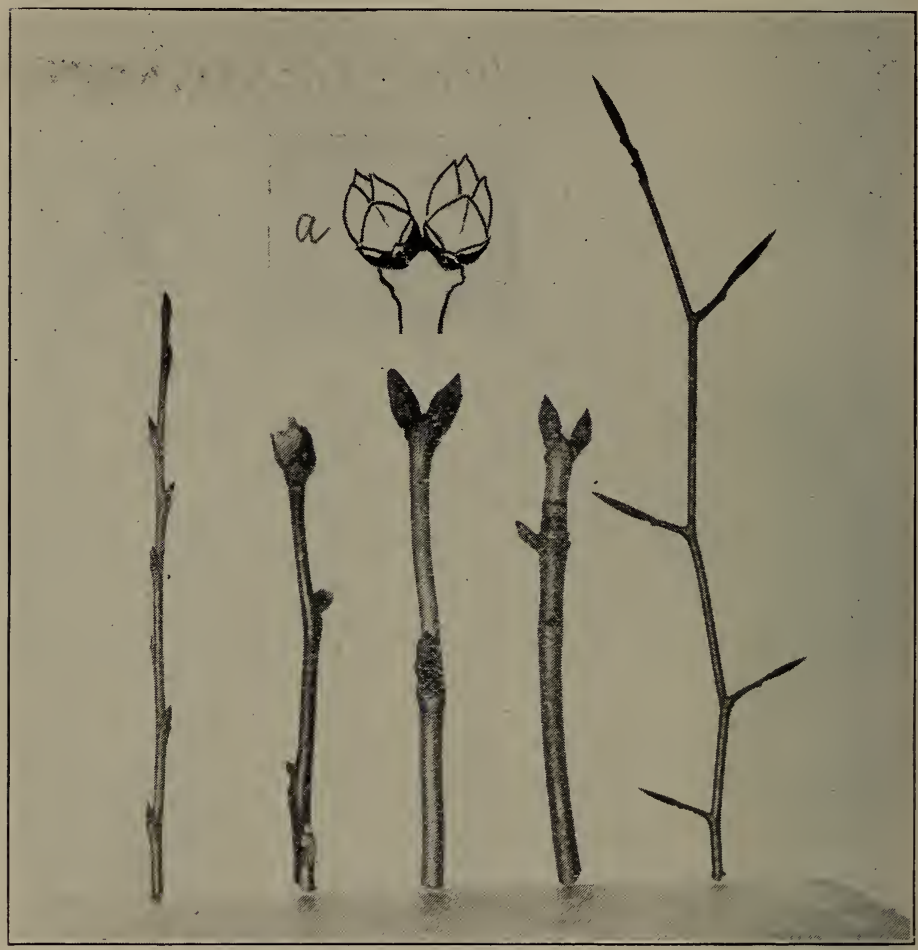

Fig. 59.

Fig. 60.

Fig. 61.

Fig. 62.

Fig. 63.

Fig. 59. Apple buds, five-ranked. Fig. 60. Large, well protected hickory buds. Fig. 61. Lilac buds; scales opposite; this is well shown in 61 a. Fig. 62. Buckeye buds. Fig. 63. Beech buds.

Exercise: Gather some large buds from hickory, buckeye or horse-chestnuts; count the scales that protect the living parts. Are there hairs in the bud to add to the warmth? Is there a varnish or any other means to prevent the bud 
from getting wet? Gather walnut, beech, lilac and maple buds. What difference is there in arrangement on the stem? Is it the same as the leaf-arrangement? Where are the buds of sycamore? Locust? Is there any tree in your vicinity that conceals its buds under the bark? Consult the accompanying Figures, 59 to 63 .

An interesting phenomenon one may occasionally see is due to latent buds. The early buds of willows are sometimes killed in spring by frost; the trees have the power to produce branches in this case by means of the latent buds; but considerable time is required to bring them on; so the willow's second spring dress comes later than the leafing out of the forest trees. It is as if it had resolved not to be caught the second time.

During the winter of 1900-1901, most of the sycamore buds were killed by the severe cold; in the spring the few buds that had escaped leafed out and after two weeks or more latent buds were developed on the other branches and the two sets of leaves of different sizes could be distinguished until midsummer.

\section{LESSON XXXVIII.}

\section{Adaptation to Climate.}

The Persimmon Tree. A Special Case.

Examine carefully several branches on which persimmons grow and you will find that they grow on branchlets that have grown the same year. This is greatly to their advantage during winter. Fruit can hardly be killed when it does not exist. The winter might be so cold as to kill the tree; but if it is not, the branches of the year will grow out and put out flower buds and flowers and bear fruit. This is a great advantage and would leave the persimmon quite ahead in the struggle with frost, only it must take also its 
disadvantage, which is that a much longer time is necessary in which to mature its fruit, and so it may be caught by the frost.

\section{LESSON XXXIX. \\ Adaptation to Climate. \\ Influence of the Wind.}

Figure ( 4 shows a Norway spruce. It grew in an open space where light could be had in all directions. It should

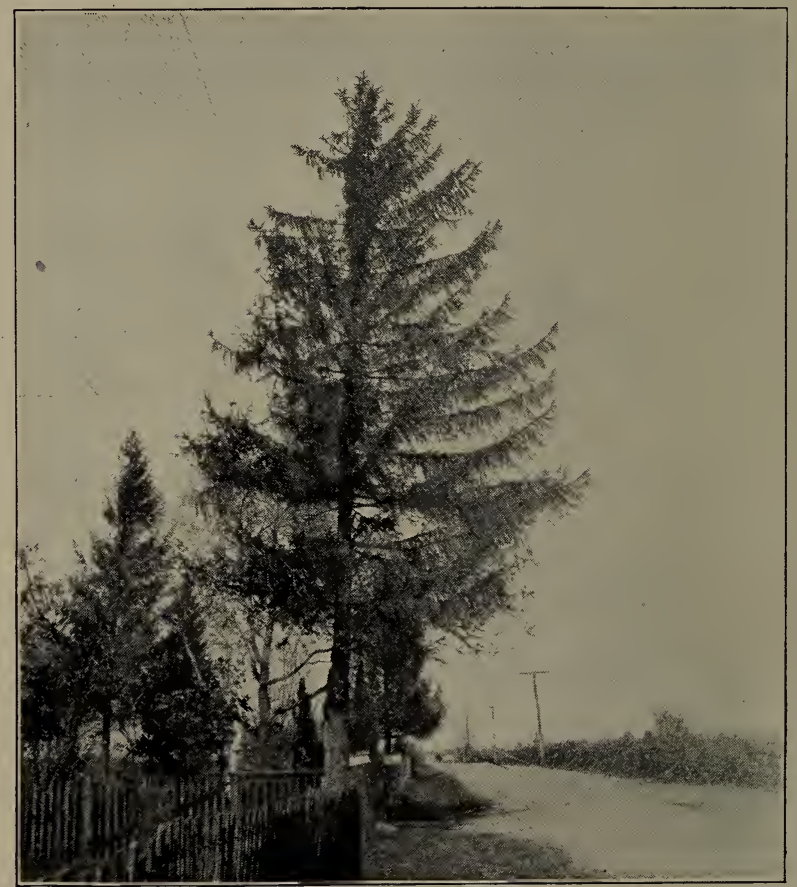

Fig. 64.

Norway spruce; branches longest on the leeward side.

have been as symmetrical as the fir in Figure 4 is. Notice 
that the branches are longer on the right hand side. This was the northeast side of the tree. To the southwest there is an open space of several miles; prevailing southwest winds have thrown the symmetrical light influence out of balance. They have lessoned growth on the southwest side and increased it on the northeast side. In many countries the winds are stronger and they blow much more steadily than with us; in such places exposed trees lean and stretch their long limbs in the direction the wind blows in a very striking

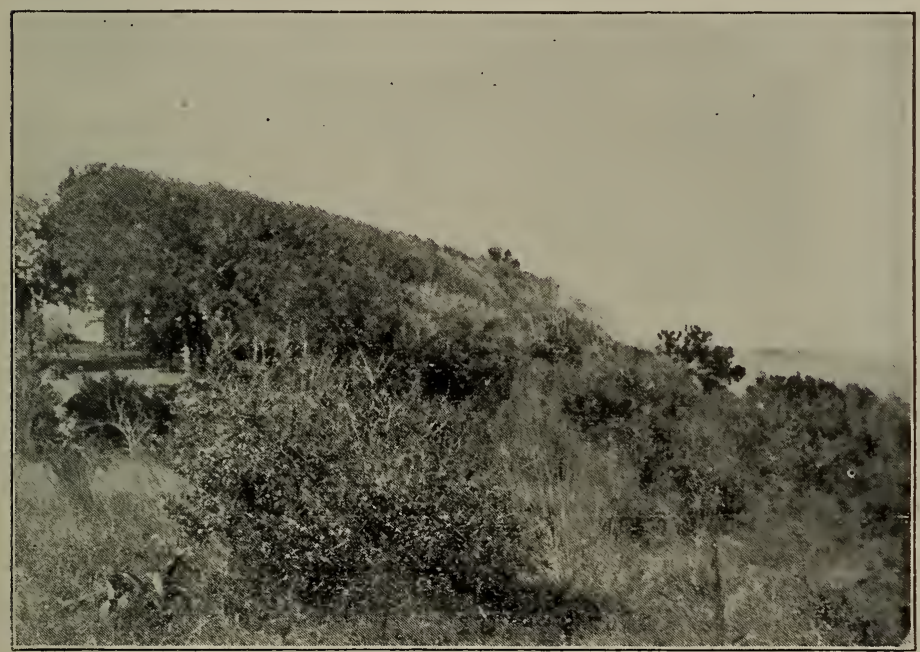

Fig. 65 .

A live-oak forest leaning from the seaward, windward side. Melbourne, Fla. View from the south.

manner. Figure 65 shows a live-oak forest near Melbourne, Florida, every tree of which leans very strongly from the ocean, the direction from which the prevailing winds come. Figure 66 shows a single oak from the same forest photographed from the other side. Neighboring trees made it impossible to get the entire tree in the picture. That it leans from something is, however, evident. 
Exercise: Find twenty-five exposed trees and see if you can determine by a study of them that the prevailing winds

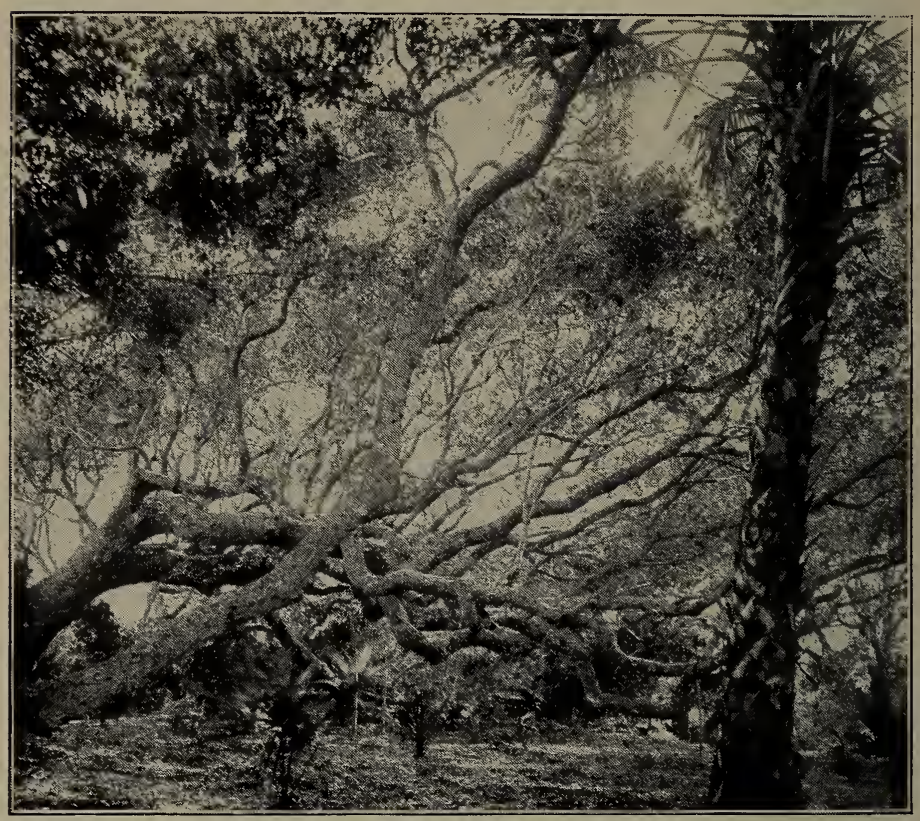

Fig. 66 .

A single oak of the forest shown in Figure 65. View from the north.

have modified their growth; look in places between forests that act somewhat funnel-like in directing the wind.

LESSON XL.

\section{The Leaf.}

\section{The Foliage Leaf.}

The most conspicuous thing in the plant world is the green leaf,- the foliage leaf, as we call it. A complete foliage leaf 
has a blade, a petiole, and stipules. Figure 31 shows all these parts; Figures 24 and 25 show the stipules. when there is more than one blade, we call the branched leaf compound, Figures 19 and 25. When these are arranged as in Figures 22 and 25 we call the leaf pinnately compound. When they are arranged as in Figure 19 we call it palmately compound. Figures 20 and 21 show leaves pinnately and palmately veined.

Foliage leaves have many different forms: Figures 12 to 27 show a few of them. It is important for us to consider in the presence of every tree, every plant, how its leaves, considering form, size, number and arrangement have successfully solved the problem of getting to the light. We must learn to consider green leaves as light traps; they cannot discharge their most important duty, photosynthesis, without the light. If we cannot understand this duty now, we need not be too much disturbed; no one fully understands it. See Lessons XCII and XCIII. It is enough for our purposes now to know that no tree can live without, at some time of the year, an expanse of gresn, which in our latitude, the leaves furnish.

Exercise: Learn to tell trees by their leaves. Begin with the commonest tree in your neighborhood. Collect, press, catalogue and draw accurately its leaves. Question yourself about the leaf's apex, its base, its margin, its lobes, if it has any, and its leaflets, if it is compound. Is its surface rough? Try the slippery-elm. Is it hairy? Try the white poplar. Is it smooth? Is it shining? Is the color the same above and below? Try the silver maple. Is it petiolate? Has it stipules? Is it thick or thin for a leaf? Tough or tender? What comparative advantage or disadvantage has the tree from every quality of its leaves? 


\section{LESSON XLI.}

\section{One Duty of Green Leaves.}

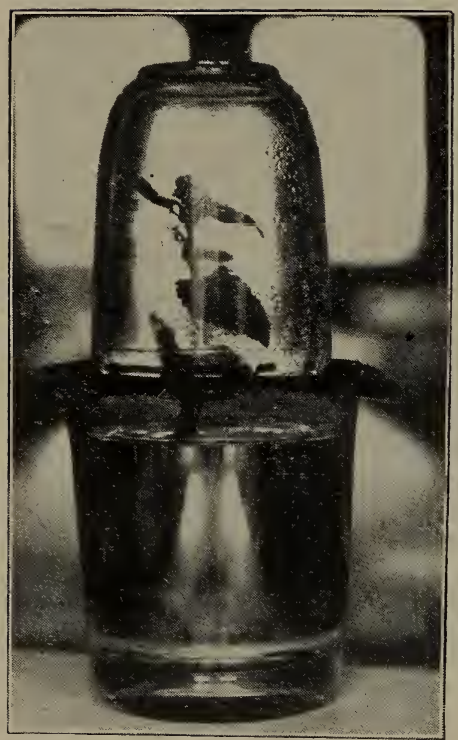

Fig. 67.

Leaves giving off moisture. Transpiration.
Figure 67 shows a fresh, green growing end of a plant which was cut off obliquely and smoothly from its stem and thrust through a card board into a tumbler of water and covered with a second dry tumbler. The leaves have given off water which has collected in droplets in the upper tumbler. This action of the leaf is called transpiration.

Exercise: Prepare an apparatus like this and after some two days try to form an estimate of the amount of moisture given off by all the green leaves off by all the green leaves of the great forest, or grass covered plain. You must not experiment alone furnishes, but it is interesting to consider to how great a thing our experiment points. The air cannot for many reasons be so dry where forests are as it would be without them. We must of course, notice that the conditions of our experiment are not those of a growing plant. Our cutting absorbs from water, not from the soil, with its varying degrees of moisture; it absorbs through its cut end, 
not through roots. The air in the tumbler where the moisture is given off soon becomes saturated with moisture, which the air surrounding forests and plains rarely is. What our experiment shows is the fact of transpiration.

\section{LESSON XLII.}

\section{The Leaf.}

Leaves in the Role of Spines.

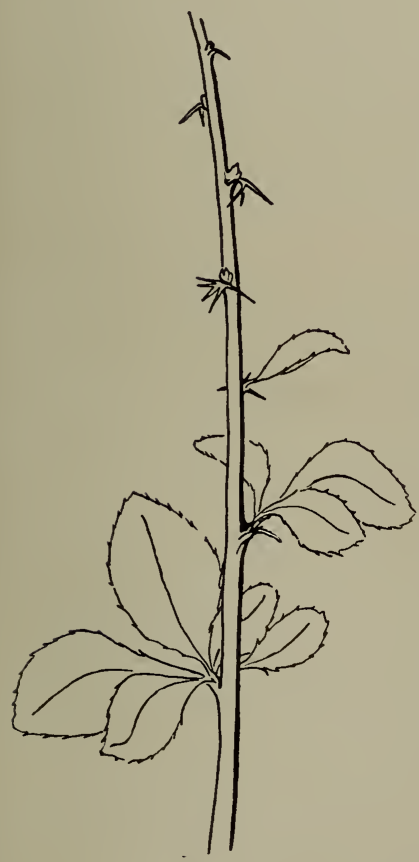

Fig. 68.

A barberry spray; leaves become thorns.
Leaves sometimes become spines; we know this because we find the spines in the position of leaves or of stipules. We know it also because we find all degrees of transition from leaves to spines. The leaf of the thistle is armed with spines. The barberry bush shows all stages in the transition from leaf to spine, Figure 68. The locust has a pair of spines at the base of its leaf in the place of stipules. The prickly ash shows a similar modification. The English holly has spines on its lower leaves; these continue as high up as a cow can reach; above this it has no spines. Southey writes of this tree:

'Below, a circling" fence, its leaves are seen" Wrinkled and keen,

No grazing cattle through their prickly round Can reach to wound:

But as they grow where nothing is to fear,

Smooth and unarm'd the pointless leaves appear." 
Spines become gradually larger until we at last begin to call them thorns; but size does not determine; spines do not become thorns; thorns are modified branches. In the same way we determine the nature of tendrils, Lesson LI, we can tell whether we have thorns or spines in a given case. Do they come off with the bark and have they the position of leaves? Then they are leaves. The position of a branch or a permanent union with the wood declares them thorns.

Exercise: Examine haws of all sorts, the honey-locust, the prickly ash, and determine whether their sharp appendages are in the positions of leaves or branches; whether they come off with the bark or are a part of the wood of the plant.

Prickles such as one finds on the raspberries must not be confounded with leaf-spines. They are emergencies in the nature of highly complex and hardened hairs.

\section{LESSON XLIII.}

\section{The Leaf.}

\section{Leaves in the Role of Bracts.}

Notice the leaves of mullein, Figure 54 . It will be seen that they decrease in size from below upward. They finally become so small that the photograph does not show them. They are mingled among the flowers all the way to the top of the stalk. These reduced leaves we call bracts. They surround dandelions and can be seen reflexed in Figure 88 . A whorl of four surrounds a group of dogwood blossoms. In this case they are very showy to attract insects. A beautiful blossom in early spring, the liverleaf that grows from a bunch of last year's three-lobed leaves has a whorl of three green bracts so close to the flower we call them sepals some- 
times; the only harm that comes from this is, it confuses us if we are hunting in a key for the name of the plant. No one can tell every time where bracts leave off and sepals begin; no more can he tell where leaves stop and bracts begin.

We will have accomplished the purpose of this lesson when we see by a study from plants themselves that bracts are only reduced leaves.

Exercise: Begin with the daisies and find as many flowers as you can that are surrounded by one or more whorls of reduced leaves. What is the chaff of oats, wheat, rye, barley, timothy hay and other grasses? See if they are not bracts, little leaves in among the flowers.

\section{LESSON XLIV.}

\section{The Leaf.}

Leaves in the Role of Sepals and Petals.

When a whorl of bracts,-reduced leaves, grows very close to the flower we change its name and call it a calyx; and instead of bracts for the separate parts, we say sepals; sometimes the sepals are green; often they are white, yellow, etc., and give its color to the flower, in part, just as the bracts themselves are colored white sometimes, as in dogwood. They are sometimes as small as the separate hairs of the dandelion's down; again they are larger than ordinary leaves as in the lily. Position alone determines whether or not they are sepals. Many flowers have just two whorls of floral leaves, Figure 40; in this case we call the outside whorl a calyx and the inside whorl a corolla. The separate 
leaves of the corolla are called petals. The sepals and petals of flowers exist under many disguises; they are grown together sometimes. One is entirely suppressed sometimes, in which case we call the one that is left the calyx; the petals often grow on the sepals; sometimes the petals are very unlike as in the bean, Figure 46 , the snapdragon, and many other flowers; so are the sepals. You will often have difficulty in determining which are sepals and which petals. Do not become discouraged at this; experts have difficulty; if you are interested in the naming of flowers you are ready for a work on systematic botany. Gray's Manual is a very good one. Details that would guide you in every case are too numerous for a book like this to give them.

The purpose of this lesson is to point out that sepals and petals whatever their shapes or disguises, are modified leaves. If it seems to you that it is impossible that organs like the spurs of many flowers can be leaves, two things will help you: Study spurs in all sorts of spurred and irregular flowers and see if you cannot arrange a list in which they become simpler and simpler until they fade out; study a very complex flower in younger and younger stages until they are so small you require a lens to see them; are the flowers more regular as they become younger? Are the petals and sepals more alike? We apply this term irregular to flowers that do not have all the separate parts of the same whorl alike. 
The Leaf.

\section{L.ESSON XLV}

\section{The Leaf.}

\section{Leaves in the Role of Stamens.}

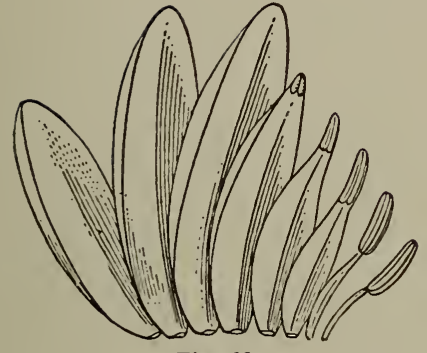

Fig. 69.

The water-lily's petals become stamens. After Gray.

We need in this lesson to know what a stamen is. Figure 69 shows a complete stamen at the right: its stem, its lower part, is called the filament; the enlarged upper part is the anther; the anther bears the pollen; see Lessons XVII and $\mathrm{XX}$. Is the stamen a modified leaf? Students where water-lilies are to be had are especially fortunate for this lesson. Go to the waterlily and see if you do not find something like Figure 69. Here is a gradual transition from a perfect stamen, right hand figure to a perfect petal, left hand figure. Other flowers will show the same thing. I have often seen it in roses. Examine the peony and you will certainly find it.

Exercise: Look at the ends of the innermost petals of roses for anthers on their tips. Gather some wild roses; try to estimate the number of their stamens; compare them with cultivated roses; have the wild rose stamens become petals under cultivation? Cultivation (plenty of rich plant food of the right quality) changes the stamens of many flowers into petals. This is another reason why we think stamens are modified petals. It must not be concluded that in the cultivated flower there is a petal for every stamen in the wild state and no more. 


\section{LESSON XLVI.}

\section{The Leaf.}

\section{Leaves in the Role of Pistils.}

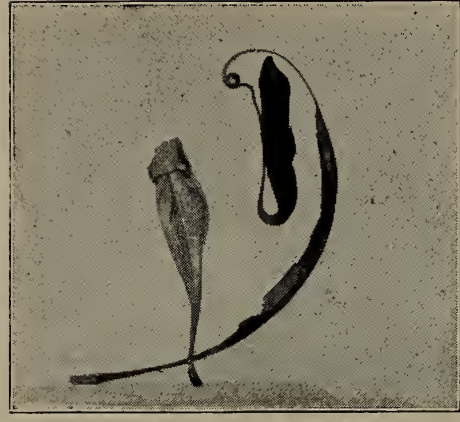

Fig. 70.

A foliage leaf functions as a pitcher and tendril. a, An East Indian leaf; $b$, ordinary pitcher-plant leaf.
We have seen, Lesson 43 , that leaves gradually change on the same flower stalk into bracts; and that bracts as insensibly become sepals; sepals in turn become petals which again may become stamens. We have also seen that leaves become spines sometimes and we shall see in Lesson LI that they become tendrils. In the pitcher-plant they become pitchers, Figure 70. In a curious plant in North Carolina leaves become traps in which flies are caught. In many plants leaves become scales. All these organs: prickles, tendrils, stamens, pitchers, scales, and the highly specialized foliage leaf itself, are doubtless end results in the transformations of a common leaf-like form. Spines would have to go back to or toward this primitive structure before they could become tendrils or stamens. For the same reason stamens do not generally become pistils; they would need to go back in most cases and set out on the new road which ends in pistils. This is what we should expect, and it is what we generally find.

Exercise: Look on double flowers of all sorts for pistils at the center and see if in many instances they have not become petal-like or even in extreme cases, green leaves again. Find some if you can that are rolled somewhat pistil fashion and with a "style-like apex." Do not be in a 
hurry to reach this or any other conclusion to which your books point. Look often and long and let conclusions grow. Examine the petalloid stigmas of the common blue flag.

\section{LESSON XLVII.}

\section{The Leaf.}

\section{Leaves in the Role of Bud-Scales.}

It will be useful to study this lesson in the spring when the dogwood begins to grow. You will find that growth from below pushes the scales up and four large petaloid leaves take the place of the scales of the flower bud. These were described in Lesson XLIII, and called bracts; the dogwood thus furnishes us evidence that bracts and scales are alike modified leaves - the scale in this instance is the tip of the leafblade; it cannot grow and its death produces a notch in the apex of the dogwood's bracts. It clings on for a while, brown, while the bract is white or greenish white.

It is sometimes the stipules of the leaves that form the bud-scales. This can be well seen in the forming of new buds of the magnolia in the fall. It again happens that the bud-scale is the petiole of the leaf. If a sweet buckeye can be found, its bud-scales will show that they are reduced and modified petioles because some of them will be tipped with the remains of the leaflets of its palmately compound leaves. Another reason why we think bud-scales are modified leaves, is, the scales are arranged on the buds in the same order that the leaves are on the stem. Consult Lessons $\mathrm{XV}$ and XVI on leaf-arrangement.

Exercise: First learn Lesson XVI thoroughly so you can quite understand the two-fifths arrangement; next examine the arrangement of the petals on a rose or apple blossom and see if it is not the same; now examine the arrangement 
of the scales on rose or apple buds and you will find that the arrangement is the same.

Exercise II: Watch the formation of beech and tulip buds and their openings in the spring and see if you can find any reason why their scales are stipules.

Exercise III: Watch the unfolding of lilac buds in early spring and you will see every stage of transition from scale to leaf. See if you can tell by the veining of a lilac budscale that it is a modified leaf-blade. Note especially the arrangement of leaves on lilac; the leaves are opposite and successive pairs are at right angles to each other. Notice now the arrangement of the bud-scales; is it the same? See Figure 61 a.

Exercise IV: Examine a spray of arbor-vitae. Its leaves are reciuced o small green scales closely appressed to the stem; see if there are not two kinds, one on the side and one on the edge of the flat branch. Examine also a spray of cedar for leaves reaticed to scales. What are the budscales of the Norway maple?

\section{LESSON XLVIII.}

\section{The Leaf.}

\section{Leaves in the Role of Bulb-Scales.}

A white lily bulb will serve us best for this study. Figure 71 shows one taken up in November,-a good time to study this lesson; any time in Autmn will, however, do. The scales at the bottom are the bases of leaves in which food has been stored up to help in making stem, flowers and seeds the coming year. The leaves which are still green at the top and still function as foliage leaves, are pale and thickened at their bases and function as storehouses of food, - a function of leaves not hitherto noted. Probably there is no leaf that does not in some part and at some time, hold some stored food. 
Exercise: Cut across an onion; does each of the several concentric circles you see represent the base of a leaf in

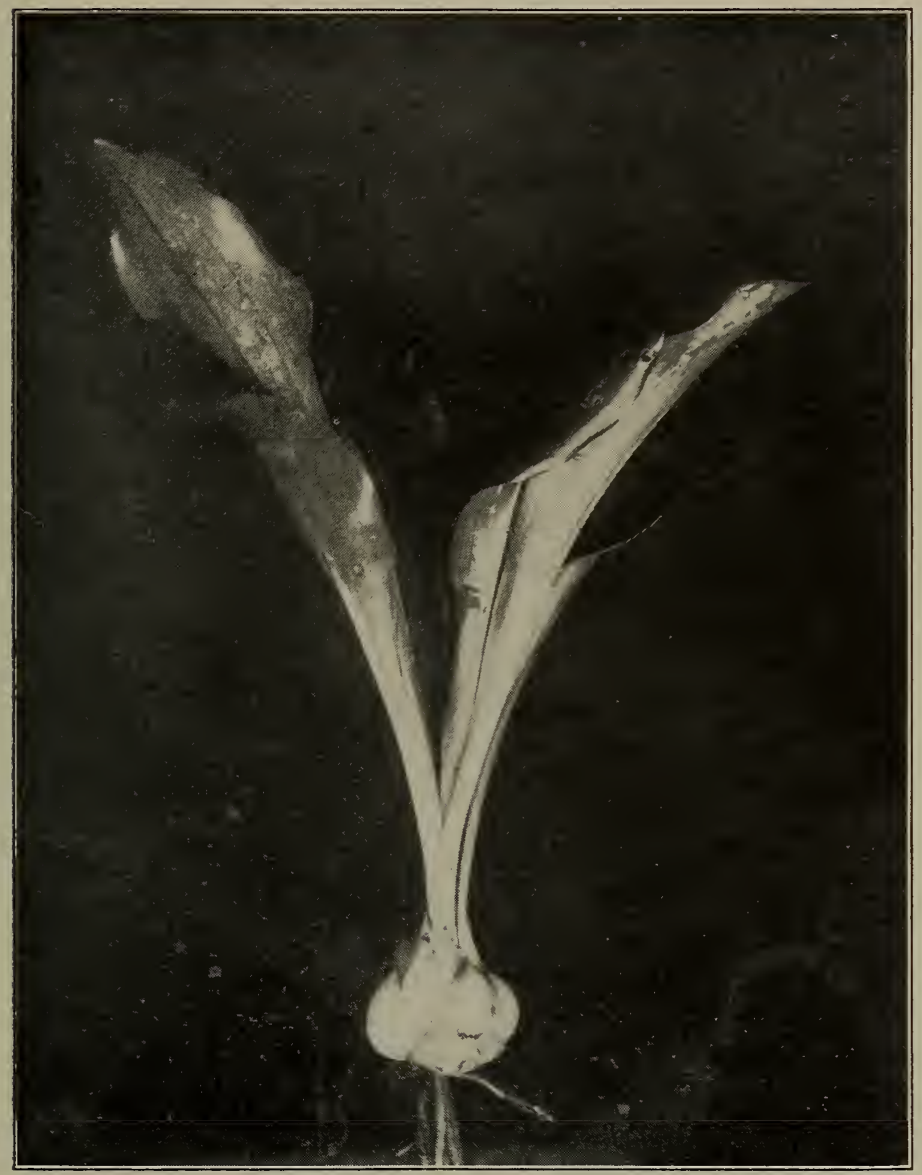

Fig. 71.

A lily bulb; leaves as storehouses for food.

which food is stored? Go for answer to the young growing onion and see if you can trace its leaves to circles in its bulbs. 
LESSON XLIX.

The Leaf.

The Pappus of the Dandelion.

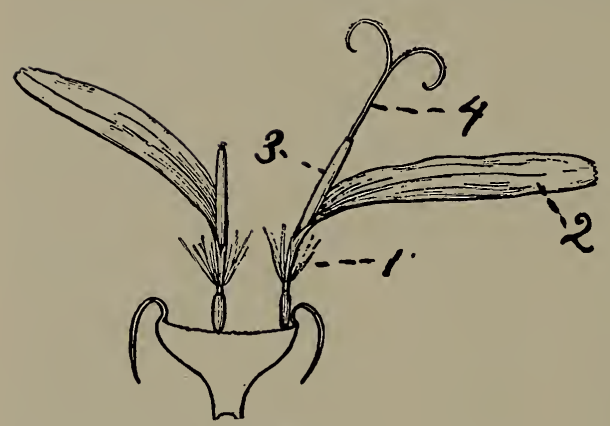

Fig. 72.

A dandelion flower. 1, calyx; 2, corolla, 3, stamens; 4, pistil. After Gray.

Exercise: Get a dandelion that has just fully bloomed; cut the large head in two from above downward so as to split the stem on which it grows. Look at the cut half of the large is not composed of separate flowers, many of which look like Figure 72. Compare this part by part with the simple flower in Figure 40 and with the separate parts of a springbeauty. You will see the same number of separate whorls in them; sepals, petals, stamens, pistils. Similar parts are similarly named in the two figures. The outside member of the dandelion flower is very unlike that of Figure 45, and of flowers generally, but we have already learned that position determines; form cannot, for forms are as different almost as different kinds of flowers. This dandelion down, then, is a modified calyx. But as we have already learned that a calyx is a whorl of modified leaves we are, therefore, justified in concluding that the down which we find on the dandelion seed and which occurs with modifications on many kinds of blossoms is an extreme modification of leaves. 


\section{LESSON L.}

\section{The Leaf.}

The Blossom End of the Apple.

What are the dead brown appendages at the blossom end of the apple? They seem to be leaf-like; perhaps they are the tip of the calyx.

Exercise: When the apple blooms next, examine the blossom carefully. The parts of the apple are present in the blossom. Some parts of the blossom are dropped, some remain and grow greatly. Mark one definite apple blossom and watch it every day until it becomes a small apple and you cannot help learning that the calyx closes in about the pistil and at last fuses with it and then both thicken together. As the calyx consists of modified leaves and the pistils of modified leaves it must be that the edible portion of an apple consists of modified leaves. You can watch the modification all the way from the leaf to the apple.

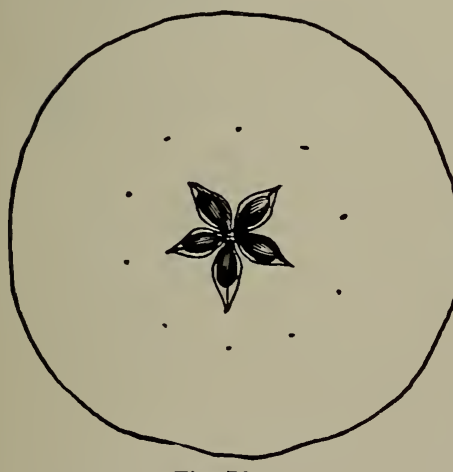

Fig. 73.

A cross-section of apple. Drawn by Miss Helen M. Fiske.

Cut an apple across midway between stem and blossom and scrape a little from next to the core; now scrape a little from next the peeling; which is softer and tenderer? See if you can tell by any appearance where the outside and inside meet. compare your cut apple with Figure 73. The leaves that went to make the apple's pistil were wrapped with the upper side in and when the leaves of the calyx were bent together their upper sides were also in. 
In eating the apple then you eat the upper side of the calyx leaves and the under side of the pistil leaves. Notice carefully this figure (Fig. 74) of the upper and under side of a leaf and see what difference the two sides present. The upper side at least makes apple pupl that is firmer than the under. The upper side of the leaf is the compact side; the lower is the spongy side.

Exercise: Pull some raspberries and blackberries yourself. Does a portion of the top of the flower stem come off with the blackberry that stays on with the raspberry? When we eat a blackberry we are eating a part of the stem that has become fleshy. Examine the seeds of the black-

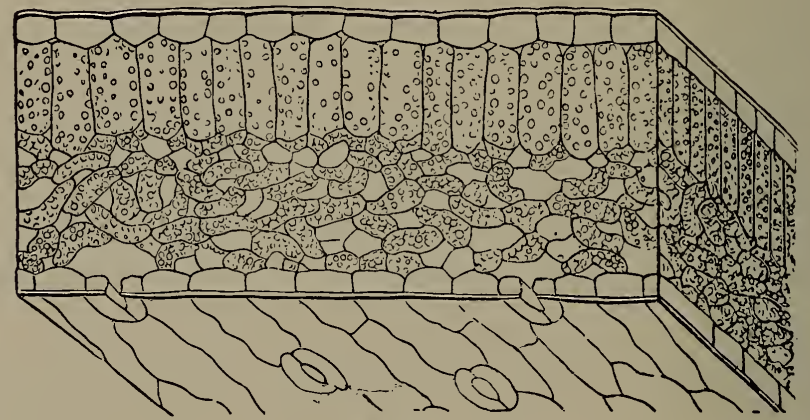

Fig. 74.

A section of a leaf. The lower side is spongy. After Gray.

berry and see if the separate seeds are not made on the plan of a cherry, a stone within and the fleshy part without. The cherry has no bloom on it when ripe as the apple has; it is the ripened pistil alone. This pistil leaf has greatly thickened; the outside which is the under side of the leaf has become fleshy and the inside which was the upper side of the leaf has become the hard stone.

Exercise IV: Study walnuts, strawberries and pears from the first appearance of the flowers until they are fully formed and see what their several fleshy parts are. Try to 
learn what parts of the st€m or flower has become tle edible portion of every fruit you eat.

\section{LESSON LI.}

Leaves in the Role of Tendrils.

Figure 24 shows us a greenbriar leaf. Its stipules have abandoned the office of foliage leaves and are entirely given up to support; they appear as tendrils. Sometimes tendrils are modified branches. If they grow out from the wood so as not to strip off with the bark they are modified branches instead of leaves. Compare the distinctions between prickles and thorns, Lesson XLII.

Exercise: Find out by this "rule what tendrils are in grapevines.

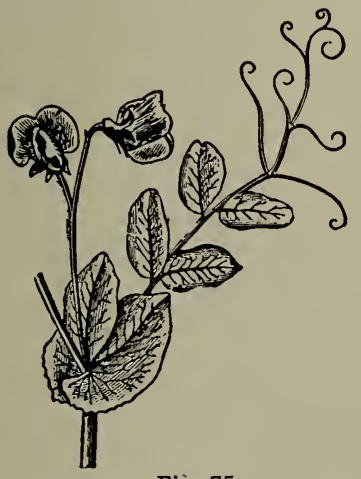

Fig. 75 .

Figure 75 is a leaf of a gardenpea; notice that in this case the leaflets of its compound leaf are, several of them, converted into tendrils and that its stipules have grown to the size of leaves to discharge the duties of the green leaf, which the leaflets have laid down in order to support the plant. Examine the sweet pea plant carefully. It has given up its leaflets A garden-pea leaf. From for tendrils also, but instead of
arnes's Plant Life. enlarged stipules for leaf surface, it has expanded appendages along its stem; Figure 76. 


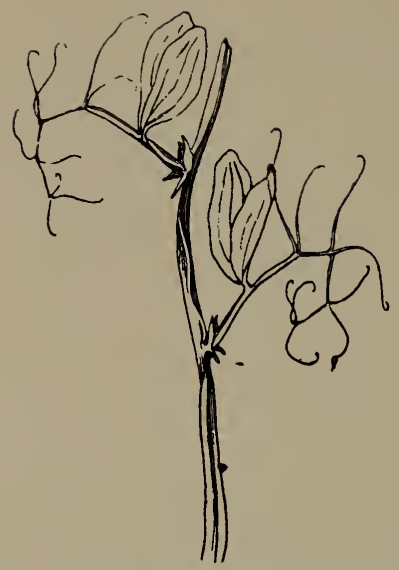

Fig. 76.

Another way to tell whether a tendril is a modified branch or leaf is by its position. Remember a branch generally grows from a bud in the axil of a $1 \in$ af,- that is, from the stem just above the leaf. Figure 77 shows a tendril of passion flower in this position. It is, therefore, a branch, not a leaf.

Exercise: Find some tendrilbearing plant not here mertioned and ascertain by one or the other, or both, of the above A sweet pea leaf. Drawn from rules, whether its tendrils are
nature by Miss Helen M. Fiske. modified leaves or branches.

\section{LESSON LII.}

\section{How Tendrils Behave.}

Exercise: Find some tendril-bearing plant and note in what direction some tendril points that is nearly grown, but has not yet begun to twine itself about an object. Watch it every ten minutes for a few hours; does it move around in a circle or an ellipse? What can it be doing? Is it hunting for something about which to twine? Let the tendril itself answer; bend a twig over so it will just lightly touch the tendril near its tip and see if it does not stop its movement in a circle and begin to twine about the twig. How long is it before the tendril has taken strong hold on its support? 


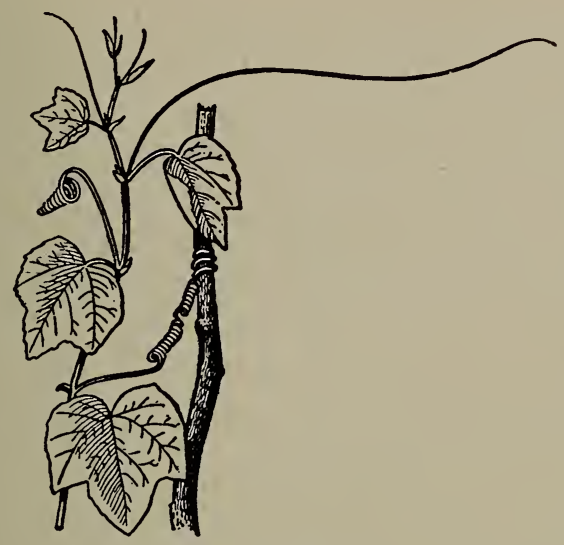

Fig. 78.

A tendril coiled between plant and support. To pull the plant nearer to the support? To enable it to yield a little in the storm? After Gray.

Examine several tendrils that have taken fast hold on some object and see if Figure 78 represents them correctly. What are the coils between the plant and its support for? Let the tendril again answer; watch its action in a storm and see if the purpose of this can be to yield somewhat to the pull of the leaves so that it may not be suddenly snapped off. May it also

be to pull the plant and support closer together?

\section{LESSON LIII.}

\section{How the Bean Finds its Pole.}

Plant twenty or more twining beans, corn-field beans. As soon as they come up put poles down for them to climb, some five inches away and on all sides of the beans. Watch the beans as they grow and see if they grow up and reach out in some direction as if hunting something. Mark the direction in which they point from hour to hour and see if they swing round in a circle in search of their pole. Do they grow a little longer and reach a little further every round? When they have almost reached the pole at a distance of several inches remove it and see how far the beans can reach. Of course the same experiment can be tried with 
morning-glories or any other sort of twining plant; it would be very profitable to try it with several twiners for comparative study. These experiments could be tried on the farm or in the garden in spring at very little cost of time. Let the results grow with the season. If the bean fails to find a pole within supporting distance, does it bend to the ground, establish a new base and begin to hunt in its new territory as before?

\section{LESSON LIV.}

The Multitude of Plants. The Struggle for Existence.

Count the grains on what you think is an average ear of corn. I have just found 400 well developed grains on a single ear. This means that one grain can become 400 in one year and this 400 can become $400 \times 400$ or 160,000 the second year; and these $160,000 \times 400$ or $64,000,000$ the third year; 25,600,000,000 the fourth year. One bushel will yield as many bushels as one grain will grains; so one bushel will yield 25,600,000,000 bushels in four years.

The earth's land surface is $52,500,000$ square miles. One bushel will plant eight acres and eighty bushels will plant 640 acres, or a square mile and to plant the whole earth would require $52,500,000 \times 80$, or $4,200,000,000$ bushels. One bushel of corn would yield enough corn in four years to plant the whole earth more than six times over.

Read the chapter, "The Crowd of Animals," in Jordan and Kellogg's "Animal Life."

Exercise: Estimate the number of beechnuts on a beech tree and allowing that each tree will begin to bear at thirty years old and bear at the same rate, how long would it require for the descendants of one tree to occupy the entire United States allowing 1,000 square feet to each tree? Read Chapter III, of Darwin's "Origin of Species." Natur- 
alists are agreed that every living species, if its food did not fail and it had no casualties from climate or enemies, could in a short time occupy all the available space. This fact makes the struggle for existence inevitable.

Count the seeds of several plants and the eggs of several different birds and insects and calculate their rate of increase and see if you cannot verify this conclusion. In this struggle for existence between plants, every slight help, every noticeable adaptation is important. A plant that has some advantages in the scattering of its seeds might win in this struggle, while other plants without these advantages, however slight they may seem, might fail. We are now to study several ways by which seed dispersal is brought to pass. The, student should not forget while working out these lessons that he is dealing with one of the means by which the plant in question has successfully held its own through the ages in the midst of a multitude of plants that would have crowded it out if they could; in the midst of many animals that have lived off of it in part at least, and in the midst of forces,- - heat, light, moisture, soil, gravity, etc., that have never been considerate of it in any way.

All the preceding lessons on adaptation to the light, and all the succeeding lessons on various topics may be profitably considered with reference to the struggle for existence. Indeed, whatever the book or lesson, if it concerns itself with any plant or animal it cannot help aiding you in your study to remember: this species has existed on the earth through its ancestors from the beginning. What qualities, what adaptations does it possess that have aided in this long and successful struggle? No one can fully answer this question nor 'does any one know all the conditions that might help to the answer. The question is not suggested because it is easy, but because it is important. Because men are work- 
ing on it and because it will help any one to interpret what he sees.

\section{LESSON LV.}

Seed Dispersal.

The Wind. Winged Seeds.

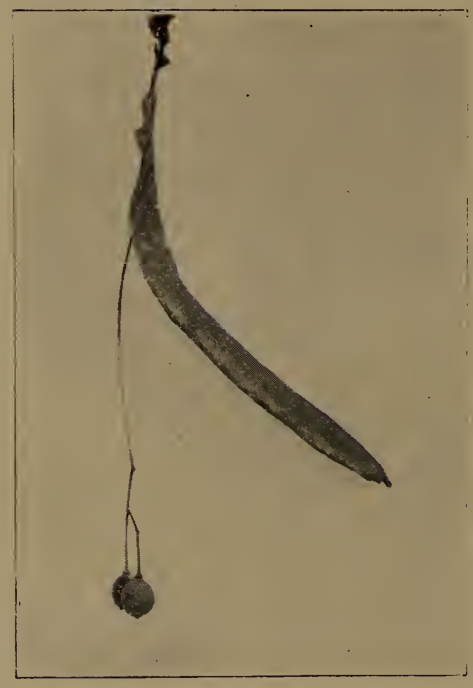

Fig. 79.

Wing-like bract of linden seed.

Figure 79 shows the fruit of the linden, often called linn. This is found hanging on the tree from August to December.

Gather the fruit when it is ripe and compare it with the figure. Drop it from a height when the wind is blowing and when there is no wind. Why does it whirl as it falls? Notice that the leaf-like bract clings to the peduncle for half its length and then leaves it at an oblique angle. Put it down and see whether it lies flat on the ground. Does it lie $i_{n}$ such a manner that the wind can easily get under it to pick it up and carry it further?

Gather in the autumn a quart of the seed of sugar-maple. When the wind is blowing, let a boy who volunteers to do so, sow a hand full from the top of the house. Every one who sees will be surprised and pleased. Go to the east side, the leeward side of a maple forest late in the fall and see the sowing of young maples the wind has effected a quarter of a mile or more from the trees. 


\section{LESSON LVI.}

\section{Seed Dispersal.}

Other Seeds with Wings.

Exercise: Gather as many as you can of the following tree seeds: ash, hop-tree, Ailanthus, (tree of heaven), waterbeech, ironwood, Catalpa and pine. The pine seeds will be found in the space just above the spreading scales of the
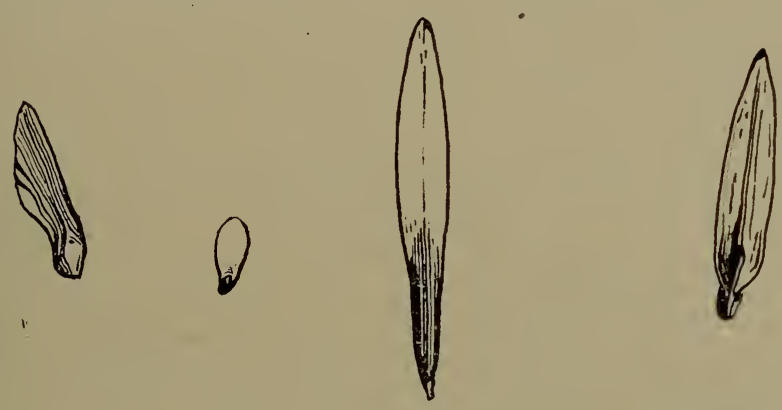

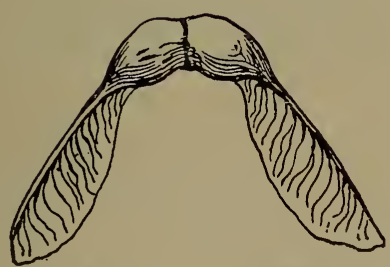

Fig. 80.

Fig. 84.
Fig. 81.

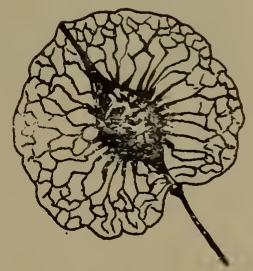

Fig, 83. Fig. 86.

Fig. 80. Winged seed of water-beech. Fig. 81. Winged seed of pine. Fig. 82 . Winged seed of ash. Fig. 83. Winged seed of tulip. Fig. 84. Winged seed of maple. Fig. 85 . Winged seed of ironwood. Fig. 86. Winged seed of hop-tree. Drawn from nature by Miss Helen M. Fiske.

two-year-old pine cones. The Catalpa seeds will have to be taken out of their long bean-like pods. All these seeds may be gathered in autumn. The seeds of the elm may be added to this list if they are gathered in the early summer 
Compare your seeds with Figures 80 to 86 . Describe them in words or sketch them or write out a description of all of them, giving special attention to the differences between them. What trees or plants do you know by their seeds? Increase this number all you can and you will be doing very valuable nature study.

When these seeds dry, do they warp in such a manner as not to lie flat on the ground? How does this help them? In North Carolina a pine forest will very soon thickly cover an abandoned field. How do the seeds get there? Read Thoreau's essay, "The Succession of Forest Trees," in "Excursions."

\section{LESSON LVII.}

\section{Seed Dispersal.}

\section{The Dandelion's Parachute.}

Figure 87 shows many dandelions bearing seeds. Each seed is provided with a parachute to carry it to some distant home. You must consult Figure 89 with dandelion seeds in your hands. How high is the $s t \in m$ that carries these seeds? Measure it and see if it is not a foot or more. You have played with these hollow stems many times, making them into fantastic curls. What are these long stems for? The dandelion flower bloomed right on the ground, did it not? The flower was very heavy; it would have taken a much stronger stem to hold it up than the dandelion has; besides. the flower is much safer on the ground than it would be a foot above it, and it can do its work just as well close to the ground. But the seeds to be well scattered must be given to the wind above the grass in which the dandelion grows so that it may not catch and entangle them close to the home blossom, so also that the wind can the better get hold of them. We need not go away from home for wonders; there is. 
not in all the earth a creature more wisely cared for than the dandelion that grows at every door.

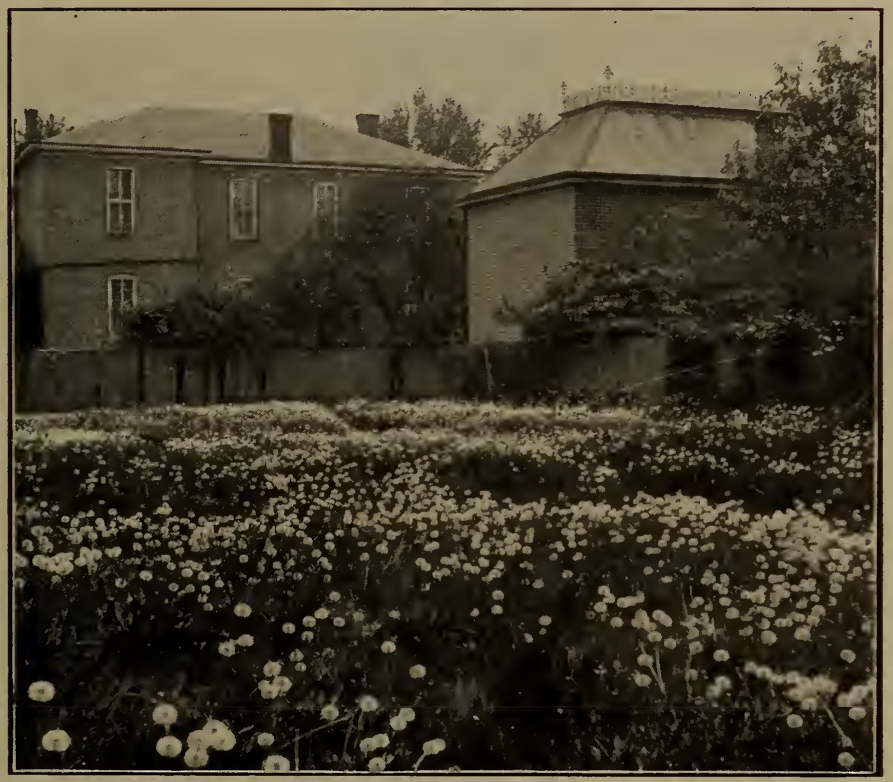

Fig. 87.

Dandelions in fruit. Photographed by Prof. J. F. Thompsor

"O'er land and sea I traveled wide, My thought the world could scan, But wearily I turned and cried Oh little world of man.

"I wandered by a green woodside The distance of a rod, My eyes were opened and I cried Oh mighty world of God."

Exercise: Mark a dandelion as soon as it blossoms so that you cannot mistake it for another. Watch it every 

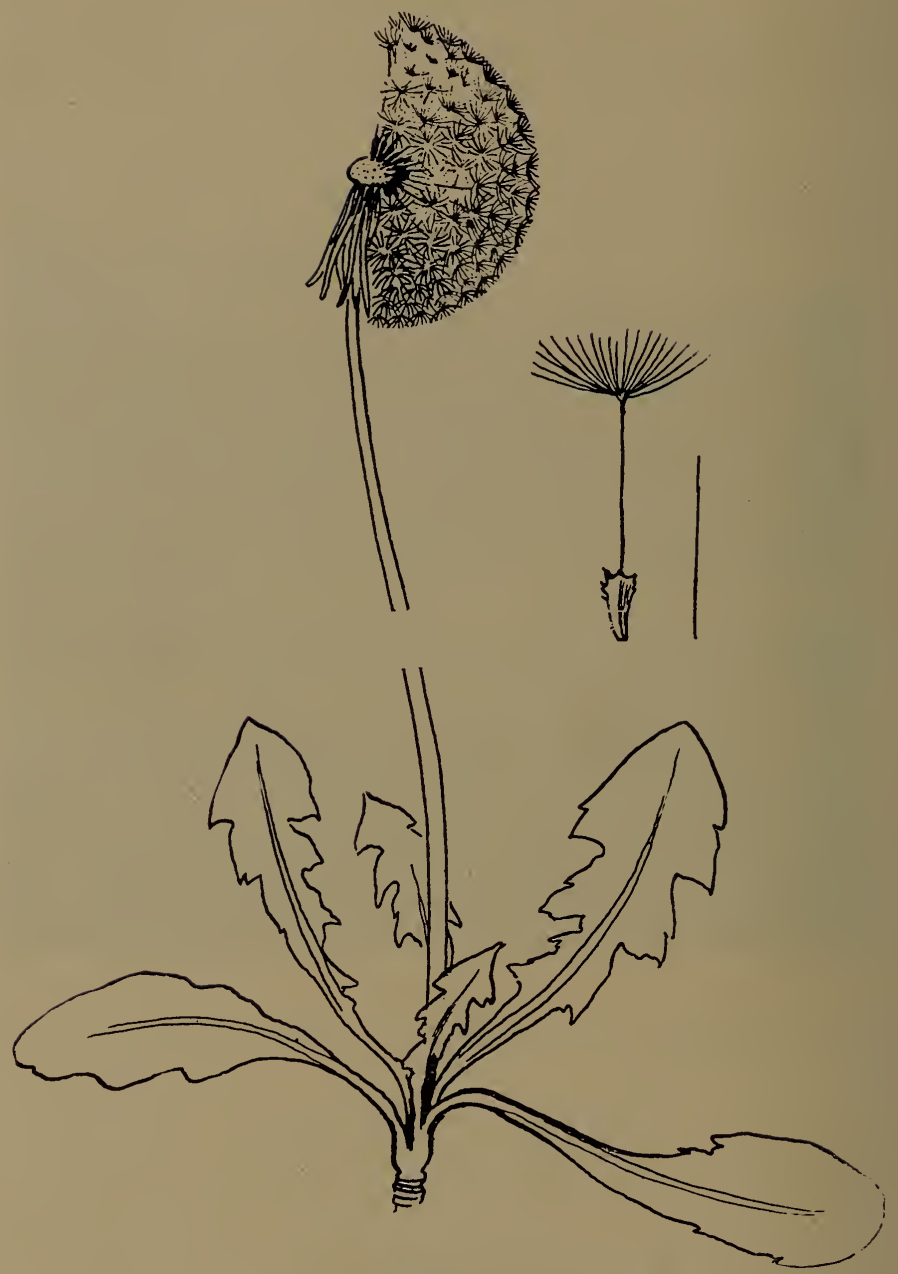

Fig. 88.

Fig. 89.

Fig. 88. Dandelion plant. Fig. 89. Dandelion seed. Drawn by Miss Helen M. Fiske.

few hours night and day, and see how quickly when the right time comes, it shoots up and sends its seeds on their dandelion mission. 


\section{LESSON LVIII.}

\section{Seed Dispersal.}

Other Pappus-Bearing Seeds.

Figure, 92 is a seed of a thistle; I isure 93 of ironweed; Figure 90 of clematis; Figure 91 of milkweed. Compare them all with the seeds themselves. Find all the seeds you can that have some kind of hairy arrangement to make them

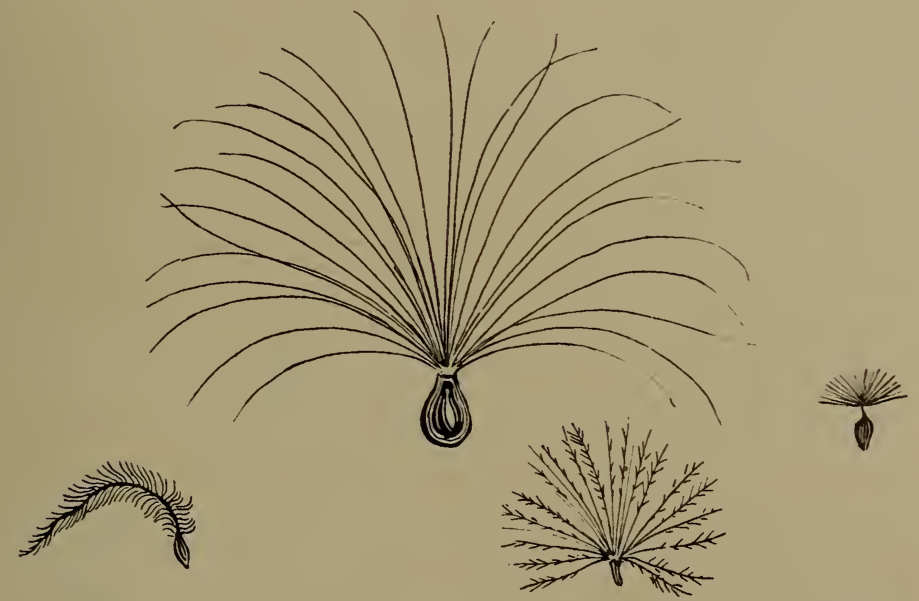

Fig. 90.

Fig. 91.

Fig. 92 .

Fig. 93.

Fig. 90. Clematis seed. Fig. 91. Milkweed seed. Fig. 92. Thistle seed. Fig 93. Ironweed seed. Drawn by Miss Helen M. Fiske.

light enough for the wind to carry them. Make collections of these seeds for your home or school in small covered glasses, jelly glasses will do, all correctly labeled with the time and place of gathering them and if you know it, the time of blossoming. 


\section{LESSON LIX.}

\section{Seed Dispersal.}

Some Adaptations of the Thistle.

The thistle has no friends in the world; it has taken care of itself for so long that it does not expect anything else; it will be worth while for us to find out how it does this.

Do not try this lesson without thistle seeds that you have gathered for yourself. Notice how very small the seeds are. Collect enough seeds of thistle to weigh a grain. Get your druggist to weigh them for you; break them off from the hairy balloon before weighing. Do not think that it makes no difference how small the seeds are; this is one of the thistle's important secrets of success in the world. If the seeds were larger they could not be sent so far even in its matchless balloon. You must not think that for thistles or men there is an advantage without a disadvantage. This small seed contains all that the thistle that is to be, heirs from its parent thistle. It will take it a long time to get a start. Go again to the pasture where you gathered the seeds and you will see thistle rosettes flat on the ground; they are one-year-old thistles. They have to work a year to make up for the small start they had in the world. Consult Lesson XII on mullein. They are storing food so they will be able to grow a stalk and bear seeds next year.

Every one knows the thistle is armed with prickles; these serve to defend it through the two whole years it requires for maturing its seed.

Exercise: Find in summer the smallest thistle you can. Mark it so you can't mistake it and watch its growth from time to time till it bears seeds the following year. 
To learn what its balloon is, see Lesson XLIX.

Read Burns's poem, "The Daisy."

"The flaunting flowers our gardens yield

High sheltering woods and wa's maun shield;

But thou beneath the random bield

$O^{\prime}$ clod or stane,

Adorns the histie stibble field

Unseen, alane."

\section{LESSON LX.}

\section{Seed Dispersal.}

Smallness of Seeds and Spores.

As we saw in the last lesson, smallness of seeds has its advantages. The seed of corn is much larger than that of the thistle. How much larger? Would you rather I would tell you or would you prefer to balance them on as delicate a balance as you can get and find out for yourself?

Because of this good start the corn has in the world, it can be planted in May and it will mature in early autumn. We sow oats in April and harvest it in July. Because smallness or largeness of seed has each its advantage, plants have carried both to remarkable extremes.

The fern gains in smallness by not producing seeds at all, but spores, which grow in spore cups collected into little fruit-dots generally on the under side of the leaf. These fern-spores are so small one can only see them with a microscope. They float in the air as a part of its impalpable dust. They often light on the perpendicular, Fig. 94.

Fern rootstock with fertile and sterile fronds. After Gray. 
they grow into small, kidney-shaped bodies, quite unlike ferns. These bodies bear on the under side rootlets, which enable them to cling to the rock, and male and fernale cells which unite and form embryos. Fern seeds then are not carried to this apparently inhospitable home, but young ferns are formed there by a minute cell of the fern, which it sends out by the wind for this purpose. The fertilized cell grows at cnce, and so has no need of seed coats for its protection.
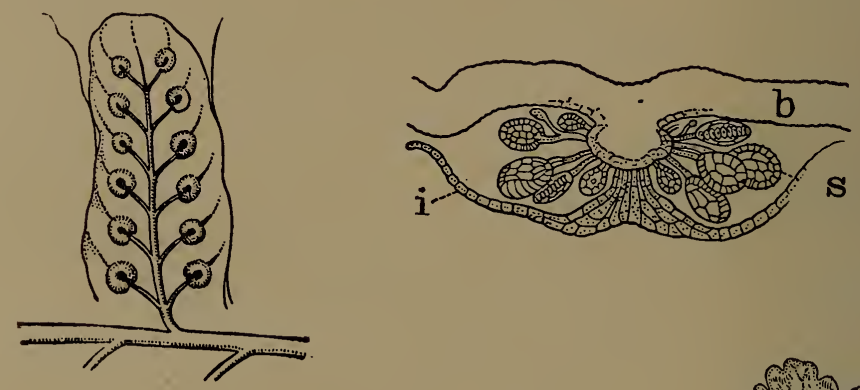

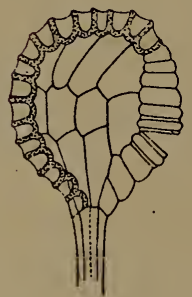

Fig. 95.

Fig. 97. $\quad$ Fig. 98.

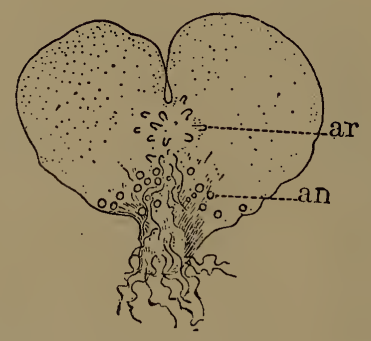

Fig. 96.

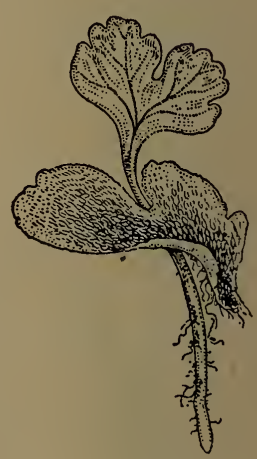

Fig. 99.

Fig. 95. Fruit-dots of Figure 94. After Gray. Fig. 96. Cross-section of a fruit-dot of Figure 94. Fig. 97. Sporangium of Figure 94. After Gray. Fig. 98. Prothallium bearing archegonia, antheridia and rootlets. After Gray. Fig. 99. A young fern plant. After Gray.

Exercise: If you cannot learn all this lesson now, you can see the fruit-dots on the under side of the fern leaf, Figures 95 and 100. You can visit the greenhouses and see 


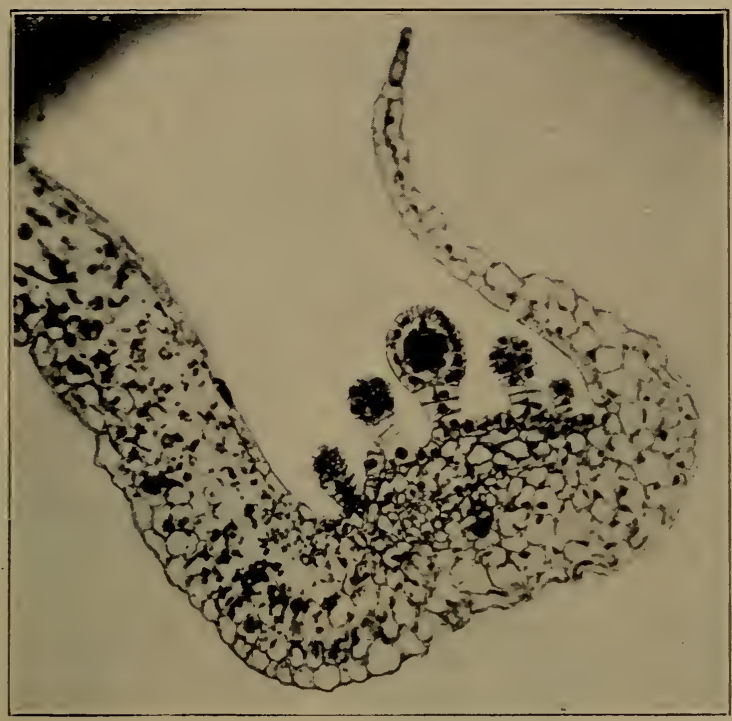

Fig. 100.

Section of fruit-dot and indusium of maiden-hair-fern. $\mathrm{x}$ by about 100 .

young ferns, prothallia, they are called, the word is plural, its singular is prothallium, Figure 98 ; and sometime you can see through the microscope the sporangium, Figure 97 , and the spores it contains. You can learn also from this lesson that when you see a plant able to live so extraordinary a life as the fern does on a rock, it is in some way specially fitted to its kind of life.

\section{LESSON LXI.}

\section{Seed Dispersal.}

\section{The Spanish Needle.}

We have seen that seeds are variously winged and are scattered by the wind, Lessons LV and LVI, that they are borne up by buoyant, hair-like appendages, by means of which the wind carries them, Lessons LVII and LVIII. 
Sometimes they cling by special contrivances with which they are provided, to men or animals, and are carried long distances. The common Spanish needle is one of these, Figure 101. Notice that the barbs extend away from the point of the needle, fish-hook-like; they go in easily, but come out with difficulty. Can any instrument be more nicely adapted to carry out its purpose than these Spanish

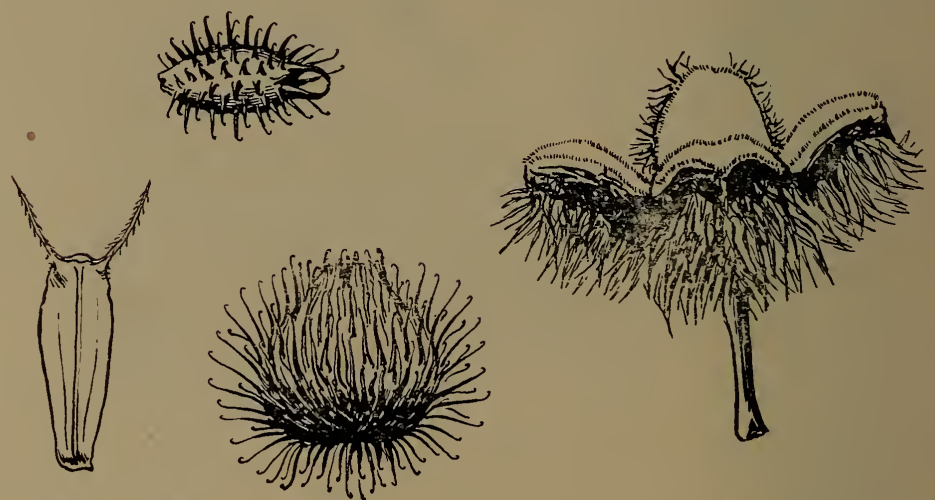

Fig. 101. Fig. 102. Fig. 103.

Fig. 104.

Fig. 101. Spanish needle. Fig. 102. Cockle-bur. Fig. 103. Burdock-bur. Fig. 104. Chestnut-bur. Drawn from nature by Miss Fiske.

needle points? How came this weed to be thus provided for? When you have really seen into a case of fitness like this, you have as much right as any one to ask this question; You had better answer it wrong than not to try to answer it at all.

Exercise: Collect as many kinds of Spanish needles as you can. Are these barbed bristle-points in or out as the seed grows on the stem? How should they be, considering the interests of the Spanish needle? Do Spanish needles sink or swim in water? How long will they swim? Do they have a seed coat that keeps them from becoming soaked for a considerable time in water? Do they grow in great abundance in corn fields that are often overflowedby streams? 


\section{LESSON LXII.}

\section{Seed Dispersal.}

\section{Other Seeds that Cling.}

Collect cockle-burs, Figure 102, burdock-burs, Figure 103, sticktights, chestnut burs, Figure 104, bed-straw seeds and as many other prickly seeds and burs as you can. You can get a pocket lens that will magnify five or ten diameters from the Bausch and Lomb Optical Co., Rochester, N. Y., that will greatly help you. Talk over with one another the differences between these seeds and their adaptations for sticking. Cockle-burs are very abundant along streams in my neighborhood, where they orerflow their banks; are they in yours? Answer all the questions for cockle-burs that are given for Spanish needles in Lesson LXI, especially the question, how many days will it swim? How long will it float in a water current and how far will the current of your swollen stream carry it in this time?

\section{LESSON LXIII.}

\section{Seed Dispersal.}

\section{Currents of Water.}

It is intimated in Lessons LXI and LXII that Spanish needles and cockle-burs are distributed by currents of water as well as by clinging to men and animals. Go along your nearest stream and get acquainted with as many plants as you can that grow abundantly and mainly, or altogether there; do not be discouraged if you cannot name them all, only be sure that you know them. You will be almost sure to find the great ragweed.

Exercise: In October gather a quantity of the seeds of the great ragweed or some other river plant bearing smooth seeds. Will these seea's float? How long will they float? How fast does your stream flow in time of flood and how 
far could these seeds be carried before they will sink? When the seeds have floated as long as they will, will they still grow if you dry them and plant them? If you try these things yourselves, you will not need to be told that currents of water plant seeds in very distant soils. Suppose a new made island is one hundred miles from land. In how many ways that you can think of could seeds get there? Could birds carry them in mud that clings to their feet? Read "Occasional Means of Distribution" in Chapter XII of the "Origin of Species."

\section{LESSON LXIV.}

\section{Seed Dispersal.}

Fruit. The Service of Animals that Eat it.

Crows assemble together sometimes to the number of 200,000 or more and roost through the winter in the same trees; such a place is called a crow-roost. There is a crowroost in Arlington Cemetery near Washington, D. C. In $1889 \mathrm{Mr}$. Walter B. Barrows collected all the droppings of the crows from two square feet, and in this material he found 4,764 seeds of plants brought there by the crows. He estimates that on the ground of the entrie roost there were $700,000,000$ seeds; enough to sow a thousand acres as thickly as wheat is sown. These were the seeds of stone-fruits, like cherries, sourgum, sumac, etc. The birds had eaten them for the fleshy part. The stones had prevented the seed from being destroyed by the digestive process.

In many parts of our country the mistletoe is found. It grows on branches of oak, elm and other trees many feet from the ground. It could not spread if its seed were not sown in these inaccessible places in some way. The seeds are gummy and cling to the bills of the birds that are eating them. The birds then fly away, wipe their bills on the 
limbs of distant trees and so plant the seeds where they can grow Figure 135 shows a section of an oak branch through its own wood and that of the mistletoe growing on it. How are the seeds of raspberries, blackberries, mulberries, wild cherries, Virginia creepers, etc., dispersed? Next time you see a bird eating a cherry don't hurry to throw at it; think of this vast and mutually beneficent relationship between plants and birds. The plants feed the birds and the birds plant the seeds for new plants. Is it not a wise, fair arrangement? Consult Lessons XXV and LXV.

\section{"-LESSON LXV.}

\section{Seed Dispersal.}

\section{Nuts and Animals.}

Have you noticed that walnut trees often grow along fence rows? They are planted there by some animals, especially the squirrel; but as he, for some reason, never returned to claim his hoarded treasure, it has grown into a tree.

Exercise: What birds or mammals feed on acorns, beechnuts, hickory-nuts, chestnuts or hazelnuts? What birds or other animals hoard them for winter use? All these biras or other animals sometimes bury or drop them at distances greater or less from the tree that bore them. Here is our wise arrangement again ; it is wiser than we think. It is not artificial. Both parties are vitally interested in maintaining it. In Thoreau's essay, "The Succession of Forest Trees," referred to above, Lesson LVI, he shows that in a neighborhood of oaks and pines, if the pine forest is cut down, an oak forest will take its place because squirrels, birds, etc., will carry acorns to the site of the original pinery. If the oaks are cut down the wind will sow pine seeds where the oaks had been. Thoreau credits Linnaeus with saying, "While the swine is rooting for acorns he is planting acorns." 


\section{LESSON LXVI.}

\section{Seed and Spore Dispersal.}

Special Contrivances.

Everyone must know that if you touch one of the ripe seedpods of a touch-me-not, it bursts with a suddenness and

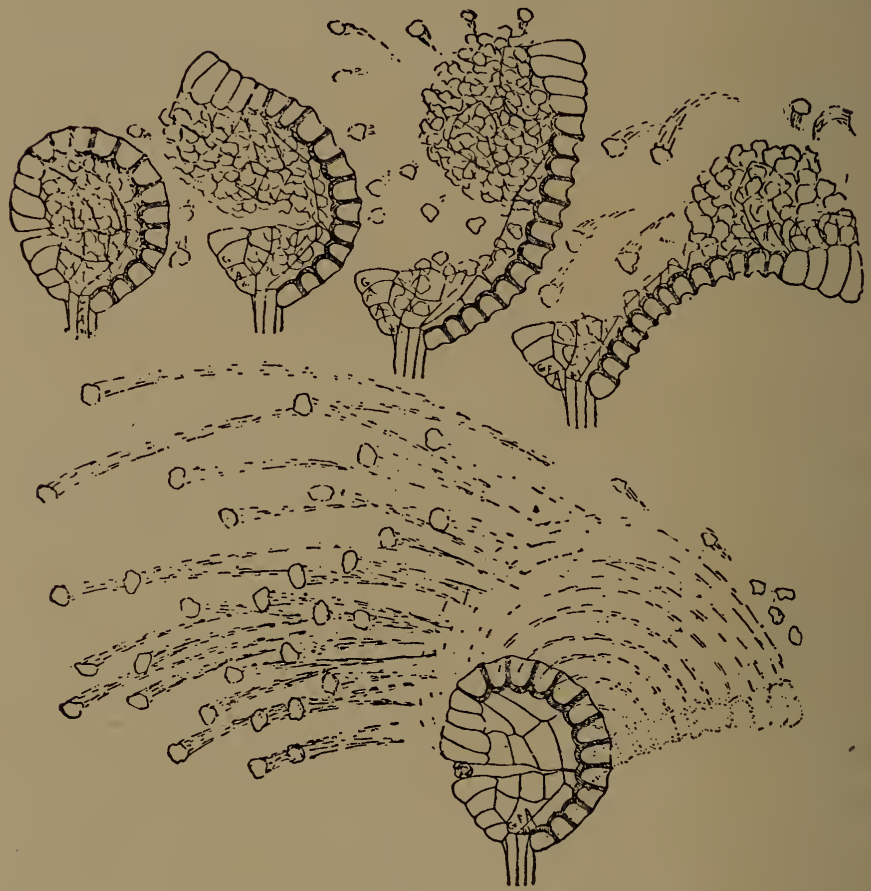

Fig. 105.

Fern spore-case discharging spores. After Atkinson.

force that send the seeds to considerable distances. The seed-pods of some other plants do the same thing-as, for instance, the fireweed, which thus gives its sail-provided seeds to the breeze.

Spores are sometimes scattered by similar means.

Figure 105 shows a sporangium of fern, greatly magnified. 
It will be seen that at the left side in the figure, the cells change in character; here the adhesion is less than otherwheres in the outer circle; the contrivance bursts here; when the cells of the outer ring dry out, their walls tend to collapse and the outer walls being thinnest, give way and a united pull is exerted; suddenly the spore-case bursts and scatters the spores to the wind.

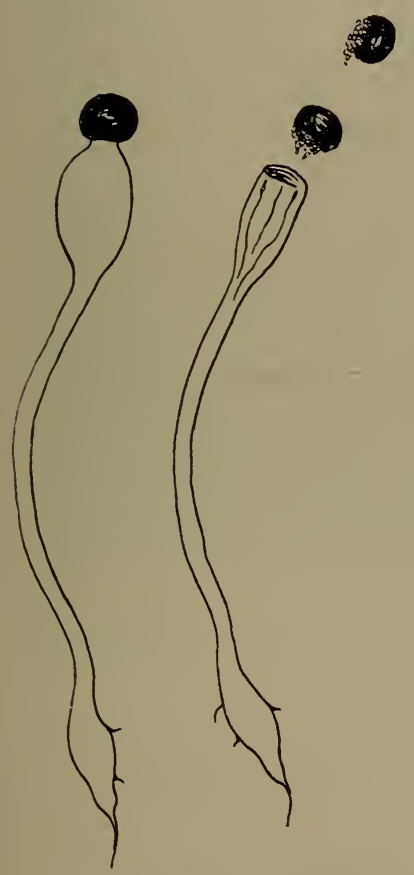

Fig. 106. Fig. 107.

Fig. 106. Pilobolus crystallinus, a mould that has no common name. See text. Drawn by Miss Fiske. Fig. 107. Pilobolus shooting its spore-case into the air and scattering spores. Drawn by Iiss Helen M. Fiske.
Exercise: Get some stable manure and put it on wet blotting paper under a bellglass. This compost contains spores of a white mould that will cover it all over in two or three days. Generally after this dies, in about nine days after the preparation is set, a mould of smaller growth comes up, Figure 106. The black cap at the top is filled with thousands of spores too small to be seen with the naked eye. When the spores are ripe, the enlarged portion of the stem swells out and pulls the part in the spore cap out forcibly and suddenly, sending the cap two feet or more into the air. The spores are caught by the wind and scattered over the grass. Stock eat them and they pass through their digestive organs without damage and if they have warm, wet weather for a few days they grow and ripen again 
in the droppings of the stock. Everything about their growth can be seen under a bell-glass, except the spores, which require a microscope. They will shoot off their little cannons, hundreds of them and cover the interior of the bell-glass with their little black caps. Get a high bell-glass if you can and see how high they can shoot. A curious thing about the shooting is, the caps always turn over, as shown in Figure 107, and land on the bell-glass spore-side up. When this shooting occurs in the open air the caps, on account of their heavier specific gravity, fall away from the spores and leave them to be scattered by the wind.

\section{LESSON LXVII.}

\section{Seed Dispersal.}

\section{Special Contrivances.}

A walnut is round and can roll long distances on a hillside. Many seeds are rendered conspicuous by being bright colored. This is true of the seeds of dogwood, black haw, wild cherry, and of berries and stone-fruits generally. Black seeds with the snow for a background are especially conspicuous. This is, of course, to attract the birds and effect the dissemination of seeds.

Tumbleweeds break off close to the ground; the weeds are generally round in shape. The wind starts to roll them and sometimes heaps them against obstacles in large heaps; as they roll the seeds are sown over the ground. Figure 108 shows pampas-grass; its tassel shaped tops break off and are carried in the same way, sowing their seed as they go. 


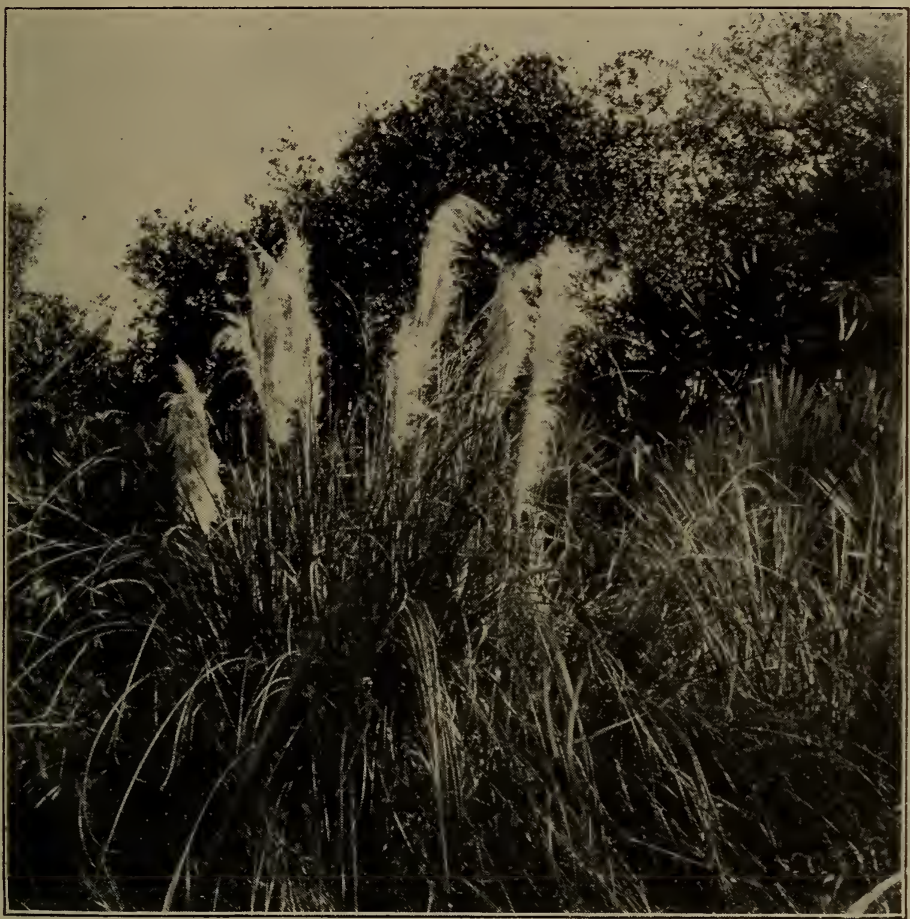

Fig. 108.

Pampas-grass; the tassel tops break off sooner or later one way or ancther and the wind scatters the seeds.

\section{LESSON LXVIII.}

\section{Seed Dispersal.}

\section{A Seed Dispersal Table.}

Sometimes edible fruits contain seeds the covers of which are indigestible; these are swallowed by birds and animals 
and dropped with their ejecta, Lesson LXIV. Sometimes as in the case of nuts and grain the seeds eaten are destroyed, but the plants bear far more than they need and many are dropped by animals by accident, Lesson LXV. Some seeds are winged, Lessons LV and LVI; some have hairy appendages, Lesson LVIII; some have hooks on the pods, which contain them, Lesson LXI; some float, Lesson LXIII, and some have special contrivances, Lessons LXVI, and LXVII.

Exercise: Try to find a plant with no special help for seed scattering.

Exercise: Fill out the following table for every plant in your neighborhood as the years go by.

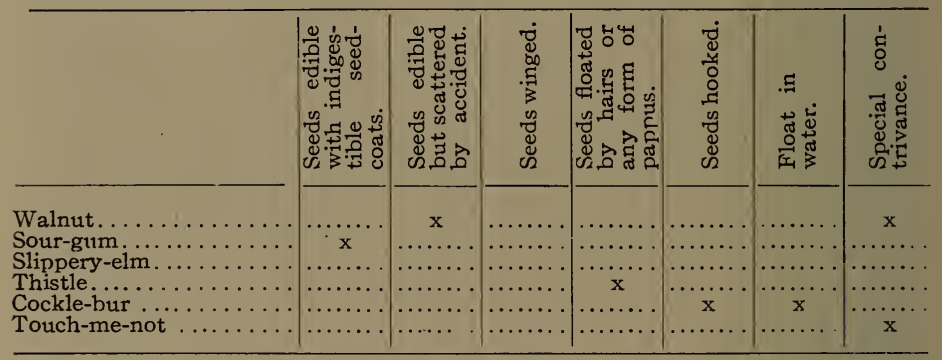

Read Chapter IV in Sir John Lubbock's “Flowers, Fruiis and Leaves." 


\section{LESSON LXIX.}

\section{Plant Societies.}

\section{Water Plants.}

Exercise: Visit several forests, especially to see if you find considerable numbers of the same kinds of trees growing in them. Do you know of a maple forest? a beech forest? an oak forest? Where can you find many willows, sycamores, sassafras, gum or other sorts of trees growing together? Do you know of a society of lilies, ragweeds, mallow, blue-grass, cockle-burs or wild roses anywhere? A group of similar plants we name a plant society. Figure 110 on St. John's river, Florida, is a palm society. This island of palms is known as "North Indiana Field." It is surrounded by shallow water in which reed societies grow. Locate as many plant societies within a half mile of the school-house or your home as you can.

Figure 109 shows four societies: lilies in the foreground, then reeds; then willows; then deciduous forest trees, oaks. Why do these plants grow together? What advantages come to them because they grow together? Do not be in a hurry to answer these questions. Do not think that you or any one else can fully answer them. You will one day travel in warmer countries than this; in colder; in dryer; in higher. There are places in your neighborhood that are dryer than others; places that have a different soil from others. The south side of a hill is warmer than the north. From what you see at home and away you may easily learn that some plants grow in the water only or in very wet soils. 


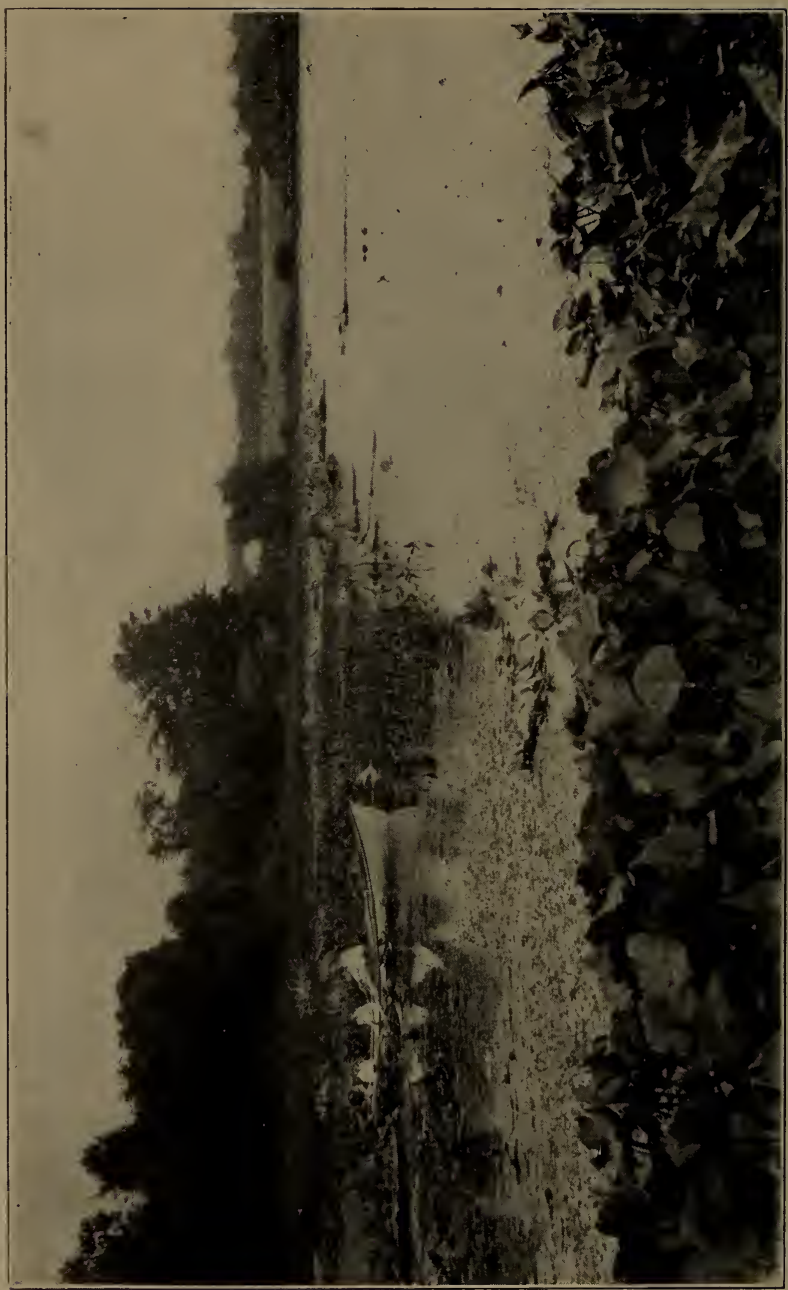

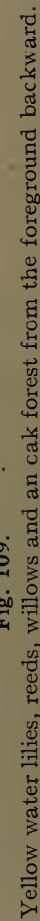

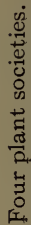


These are called water plants, hydrophites; pond-scum, stonewort, duckweed, and white and yellow water-lilies are examples.

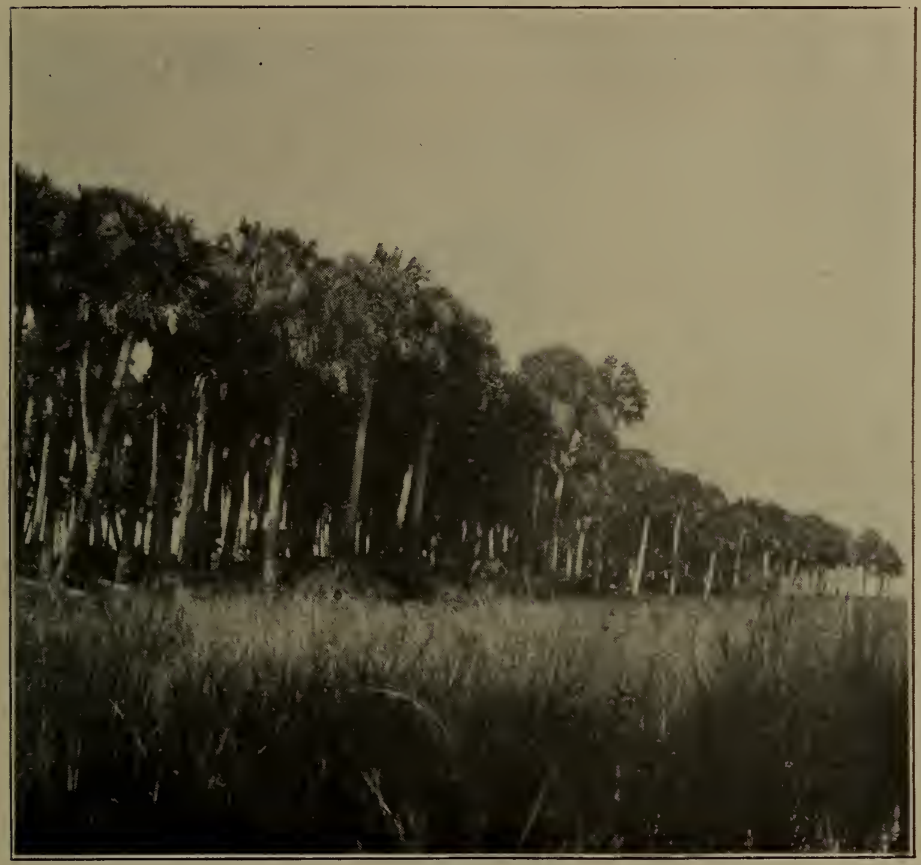

Fig. 110.

A palm society and a reed society.

Exercise: See how many different plants you can find that are free-swimming. 


\section{LESSON LXX.}

\section{Plant Societies.}

\section{Microscopic Plants.}

All natural waters, ponds, streams, lakes and the ocean itself, contain plants and animals so small that single individ-

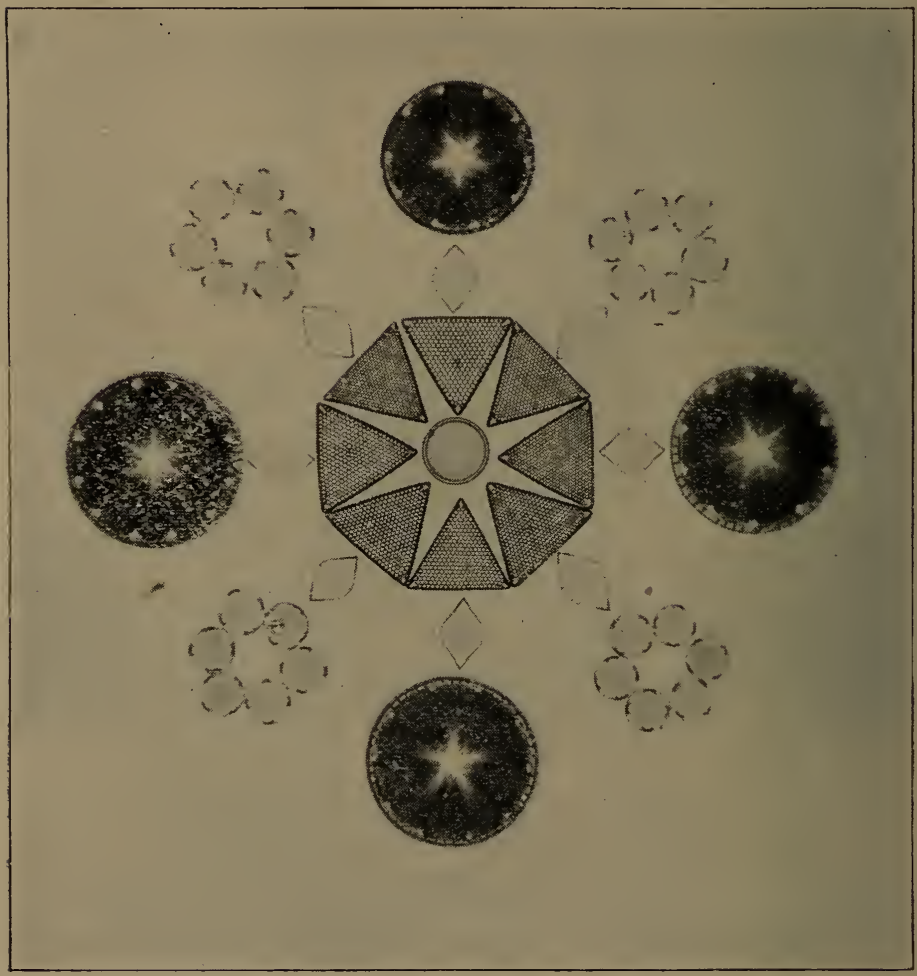

Fig. 111.

Diatom shells. One of J. D. Moeller's slides, loaned by Bausch and Lomb Optical Co., and photographed with their one-inch photo-objective. $\mathrm{x}$ by about 60 . uals can only be seen by the microscope. This life is called Plankton. Diatoms, shells of which are shown in Figure 
111, belong here. In all our streams, stones and sticks will be found covered with a gelatinous, sleek, yellowish-brown layer; this consists of millions of diatoms; there are also numberless free-floating forms; their walls are made of the same material that sand is, - silica. These plants have died in lakes and bays in past ages in such numbers as to make rock formations several feet in thickness and many square miles in extent. The shells are sometimes so small, Figure 112 , that $41,000,000$,000 can occupy a single cubic inch. Many kinđs of diatom shells are beautifully sculptured, and have been much studied on this account. Thousands of different kinds have been described and figured.

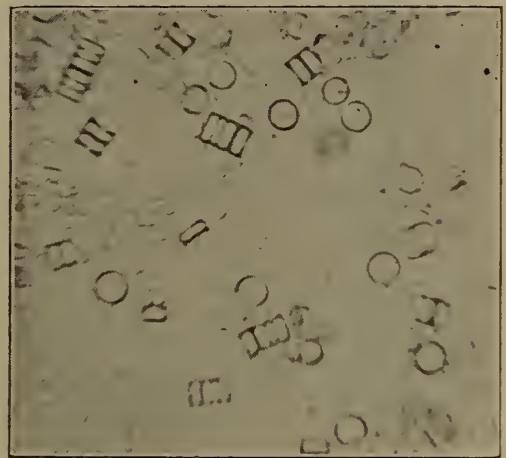

Fig. 112.

Infusorial earth. These cylindrical diatoms shown from both the side and the end are so small that $41,000,000,000$ can occupy one cubic inch. $x$ by about 500 .

Exercise: In March every stone and blade of grass in a stream near my house is covered with this yellowish-brown growth to the thickness of half an inch or more. Find this, pass it through your fingers, and if possible, look at a little of it under a microscope. The quantity of microscopic life in a lake or other body of water is important, for it determines the amount of higher life-fishes, for example, that it can support.

\section{LESSON LXXI.}

\section{Plant Societies.}

One Plant Adapted to Live in the Water.

Figure 113 is a view near Syracuse, Ind., in a bay of Turkey lake. In the view here shown there were hundreds of 


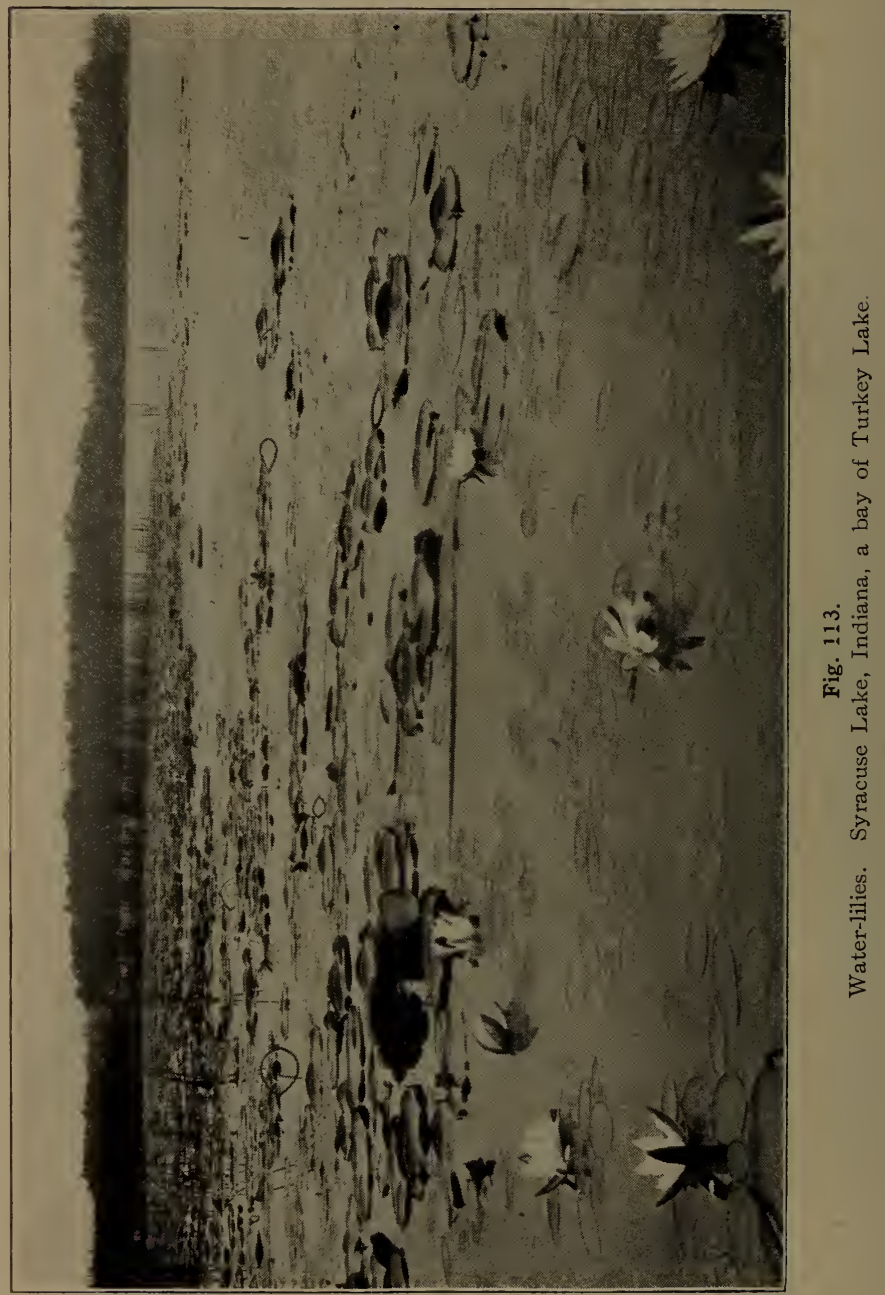


water-lilies. The lake was of varying depth from one to something like four feet. These large leaves and flowers grow from rootstocks buried in the mud at the bottom of the lake in which the food necessary to produce them had been stored up. In this way the stem is preserved from all danger. The leaves and flowers all seem to have stems just long enough to bring them to the top of the water. Pull

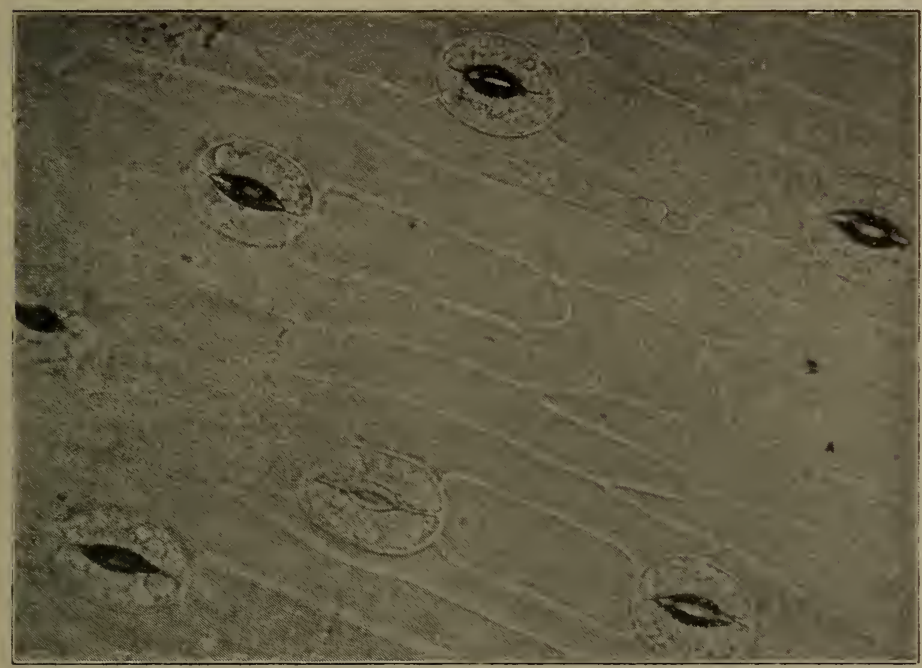

Fig. 114.

Surface view of stomata and epidermis of the pie-plant. x about 200 .

some of them up or row out to where the water is clear enough to permit you to see the bottom, and you will find that they are much longer than long enough to reach the water's surface; the extra length of the flexible stem enables it to bring leaf or flower to the top in varying depths; they can thus ride on the crests of the highest waves that are likely to come on the lake. They are buoyed up by aircavities that make them lighter than the water. These 
cavities serve also to conduct air down to the stem. Figure 115 shows such cavities in a kindred species. Figure 114 shows the stomata of leaves under a high power of the microscope. It is through these openings that air enters the leaves. In Lesson XXXV there is a cut of a crosssection of a stoma. Most leaves have these openings more numerous on the under side. This is, of course, not possible for the water-lily; its stomata are all on the upper side; an adaptation to its life in the water.

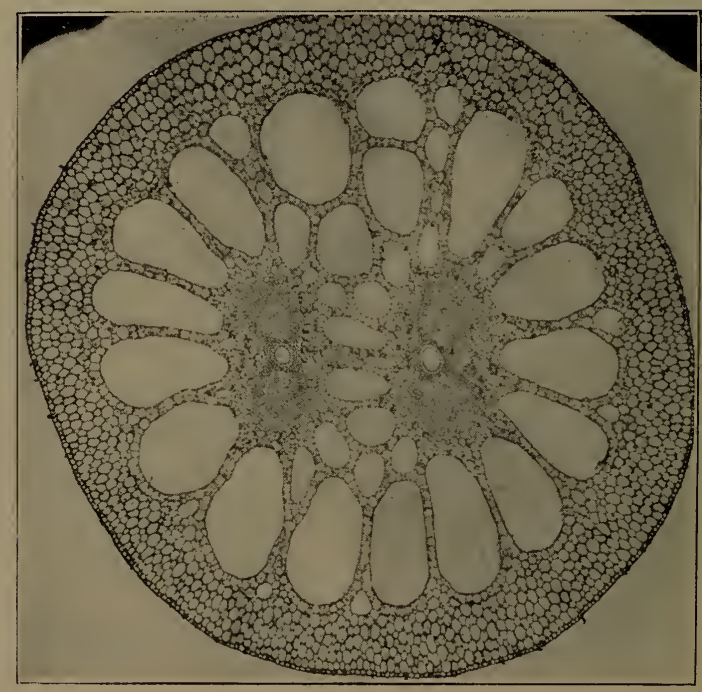

Fig. 115.

Brassenia; cross-section showing air-spaces from stomata to parts under water. $\mathrm{x}$ by 20 .

Exercise: Find water-cress and compare its stem for stiffness and toughness with the stem of several air-plants of about its size. Take stonewort from the water or any other plant that grows upright in the water, and try to make it stand erect on land. Its weak stem is nicely adapted to support in the water, but it cannot stand in air. 
Plant Societies.

\section{LESSON LXXII.}

\section{Plant Societies.}

\section{Desert Plants.}

No life is possible in an entire absence of water,' but certain adaptations enable plants to live for long periods

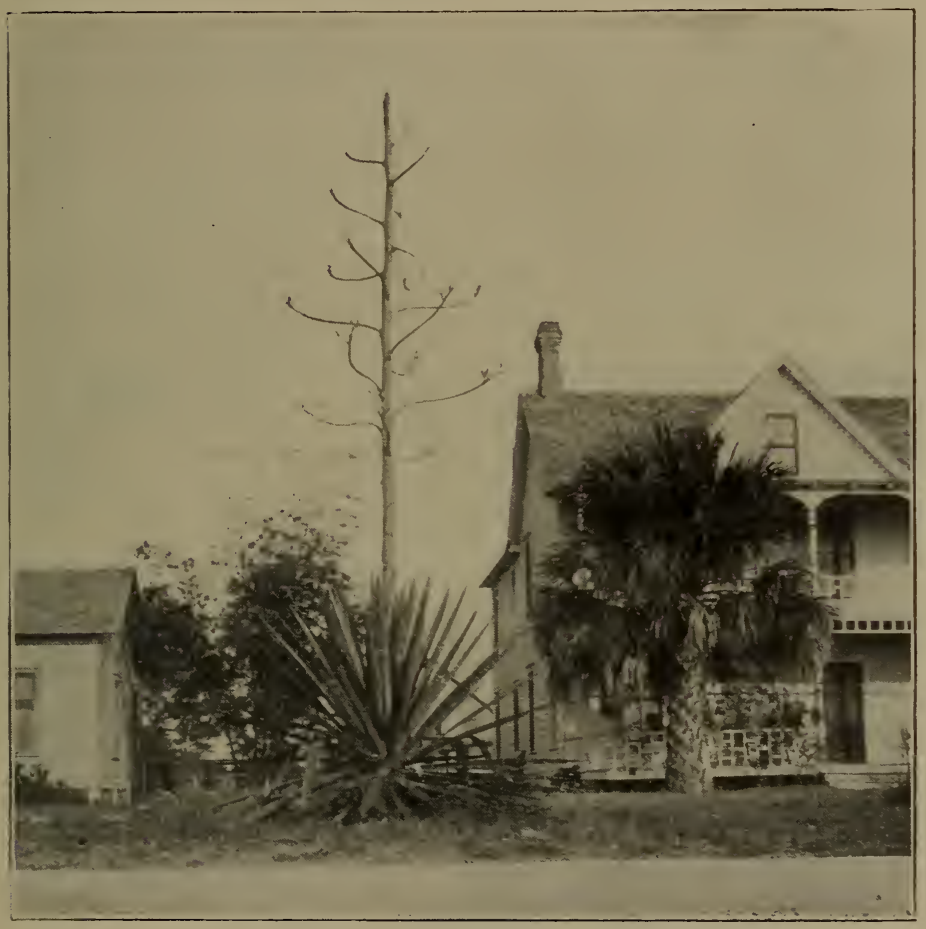

Fig. 116.

Agave sisalina. nearly ready to flower. One million seven hundred thousand dollars worth of sisal hemp, the fibers of Agave have been shipped in a year from Progreso. Notice the 3-8 arrangement of its flowering branches; the 9 th over the 1 st.

without rain. They sometimes have, under a tough and close exterior which reduces transpiration to a minimum, 
spongy tissues adapted to hold water for a long time. The lichens that grow everywhere on stones and trees have these qualities to a considerable extent. The century-plant is one of the most widely known plants that has its home in arid regions.

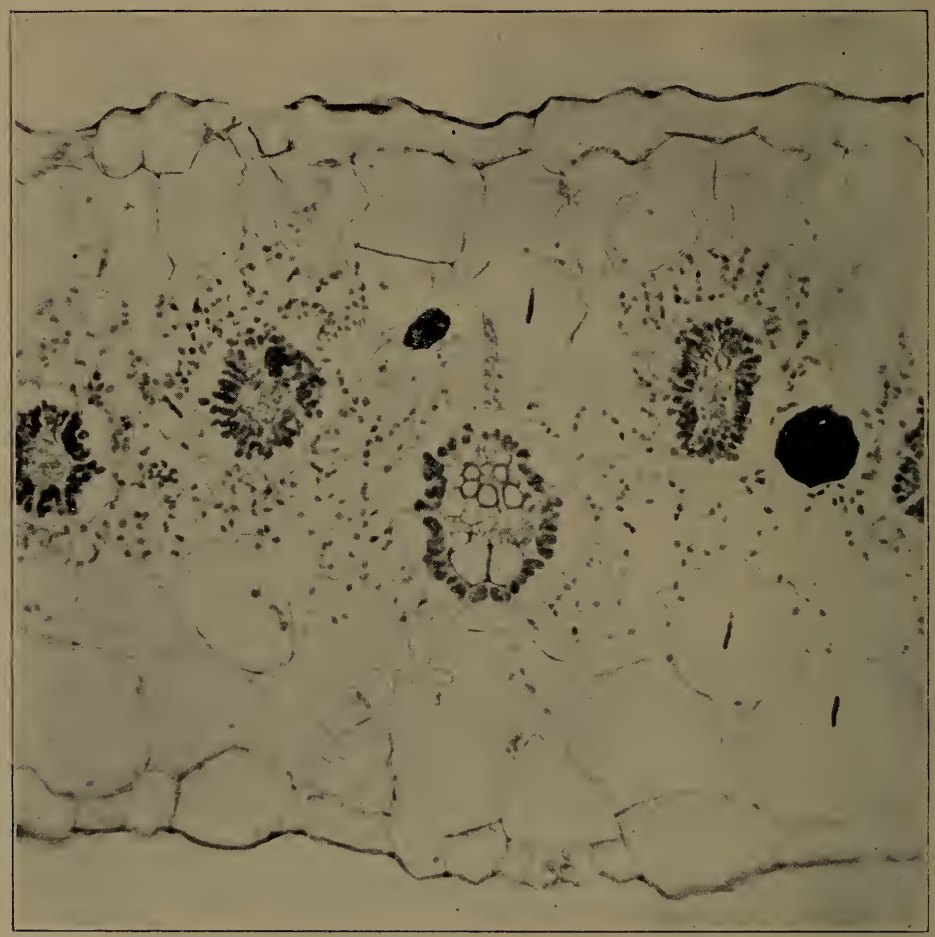

Fig. 117.

Cross-section of a purslane leaf. Notice the large reservoirs for water, between epidermic and chlorophyll cells. Does purslane flouish in dry weather? $x$ about 200.

Exercise: Cut across an Agave leaf and notice the leathery outside to check the escape of moisture, the spongy inside to contain it and the strong spines to ward off the 
attacks of browsing animals. Notice the reduction of surface in proportion to the size of the plant. Why do corn blades and mosses roll on a dry day? How does this affect the exposed surface? If it reduces it, it checks to that extent the escape of much needed water. Figure 117 shows a cross-section of a leaf of purslane; a widespread plant that flourishes in the dryest season we have, and that every gardener knows is not easy to kill out; our figure shows why; the large cells labeled 1, are water reservoirs. These adapt the plant to our August weather.

Read Charles Dudley Warner's "My Summer in a Garden" for a lierary man's view of "pusley."

\section{LESSON LXXIII.}

\section{Plant Societies.}

\section{Adaptation to Moisture. Land Plants.}

Between the reed growing in the water and the cactus on the arid plain, we have plants adapted to all degrees of moisture. Mosses grow best where the soil is wet. In a very rainy country like Scotland this may be on the tops of high hills. Cattails and other reed like plants grow in a foot or less of water or on the muddy shoals that immediately surround water. Willows and sycamores grow in soils that may be termed anything from damp to dry; while many grasses and herbs and forest trees and shrubs grow in soils that we call swampy and on dry hills as well if precipitation is distributed somewhat evenly throughout the year as it is in most of the United States. Conditions like ours are termed mesophytic conditions and the plant societies are called mesophyte societies. As compared with the extreme water plants and desert plants, ours are vastly greater in variety, in abundance, and luxuriance of growth. 
The great characteristic of mesophytic vegetation is its expanse of green leaves. Figures 2 and 3 show us mesophytic landscapes in their winter condition. The backgrounds of Figures 109 and 113 in their summer condition.

\section{LESSON LXXIV.}

Plant Societies.

Some of the Advantages of Mass Life-Society Life.

1. Cross-pollination with all its advantages occurs when large numbers of plants grow together.

2. Small patches of herbs might be wholly stripped of seeds by animals and the species might thus be stamped out in a community, while larger areas could supply the demand and still have seed enough left. This reason applies, of course, to ravages of insects as well as other animals.

3 . Forests often resist a storm that easily uproots single trees that are larger and stronger, but unsupported.

4. The competition of forest life brings every tree that survives to its best.

5. The leaves that are shed and the limbs that fall make a covering for the ground that helps to retain moisture.

6 . The combined shade of a forest also helps to retain moisture.

7. Is a tree warmer in the forest than in the open field?

8. Do the conditions mentioned in 5 , make the soil richer in the forest than it is about a tree in the open field? 


\section{LESSON LXXV.}

\section{Plant Societies.}

\section{A Walk in the Woods. Forestry.}

Select for this walk a day when the ground is sufficiently dry after copious rains have fallen. Get entirely out into a primitive forest. Leaves and sticks will be found entirely to cover the ground to the depth of several inches. Rake these aside and see how they conserve the moisture, prevent quick evaporation. Visit a large tree that has blown up recently by the roots; estimate how deep in the ground the roots certainly go. Is not each one of these roots and rootlets a water way to conduct the rain down into the ground? Does the forest not make of the ground a gigantic sponge that receives and retains water which would otherwise hurry back to the rivers and oceans? At another time visit an old mill site that no longer has water enough to run it. How many of these can you hear of in the neighborhood. Find out from the oldest settler about the springs that now are dry. Visit one. How many spring-houses are there in the neighborhood that now are without springs? It does not follow from all this that no forests should have been cut down. We had to have much of the ground for grain, but it does follow that we need forests; more than we have. They should be planted on the hills, the poorest land. We should begin to learn that before long we shall be compelled to plant forests as the old world has had to do. 


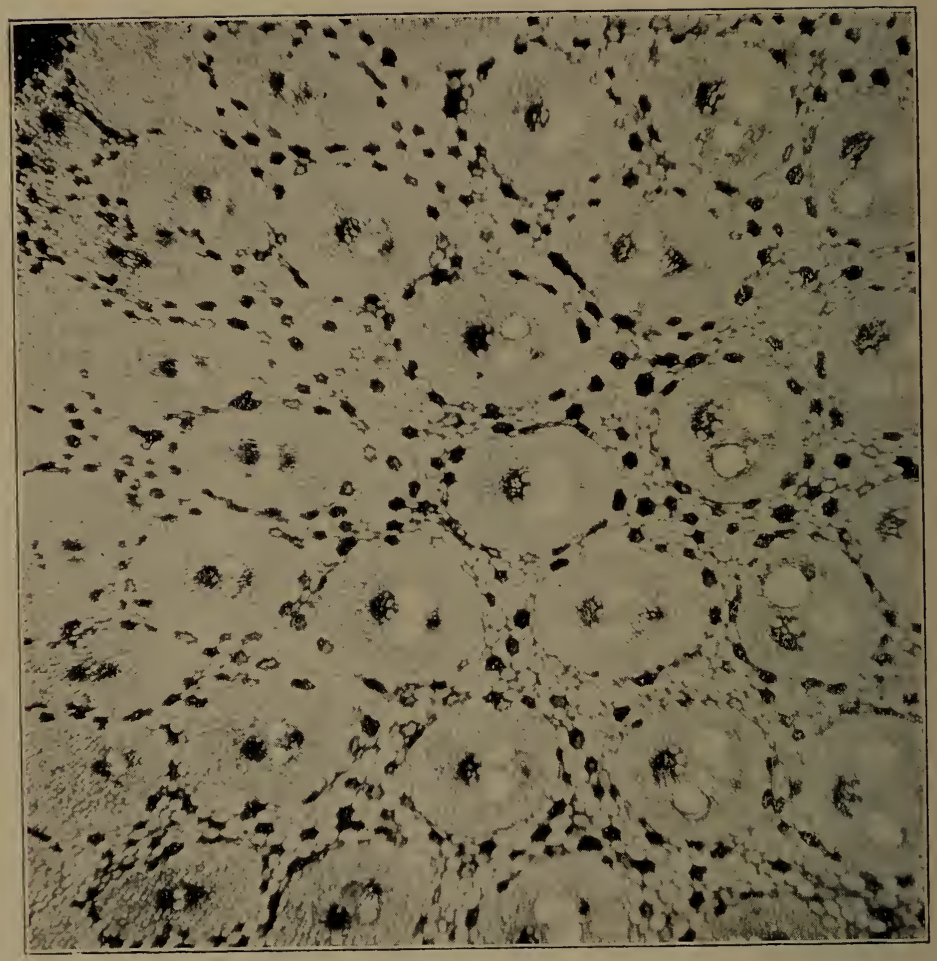

Fig. 119.

A cross-section of smilax stem showing the bundles scattered in the pith. $\times 30$. 
Stems.

\section{LESSON LXXVI.}

\section{Stems.}

The Fibro-Vascular Bundle.

Every one has whittled a cornstalk and seen the strings tougher than the pith, irregularly distributed through it.

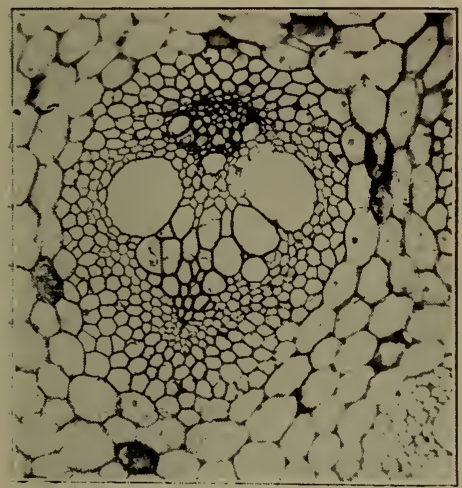

Fig. 118.

A fibro-vascular bundle of smilax. See text. $\mathrm{x}$ by 80 .

These are called fibro-vascular bundles. Figure 118 is a cross-section of such a bundle from smilax. It contains large vessels arranged in the shape of a $\mathrm{V}$, through which the sap rises to the leaves and flowers above. Beside the large conducting tubes two other kinds can readily. be distinguished, the small, thick-walled fibres, enclosing the rest and some irregularsized tissue which is generally to be found on the side of the bundle next to the bark; in this bundle the upper side, the open angle of the $\mathrm{V}$. This is called the sieve tissue.

Exercise: Cut off stems of the following plants: corn stalk, Trillium, lily and geranium, and set them in bottles of water that has been colored with a little eosin,--red ink will do. After a few hours, and then daily for several days, take some of them out and split them lengthwise and see if you can determine that the sap is rising through these fibro- 


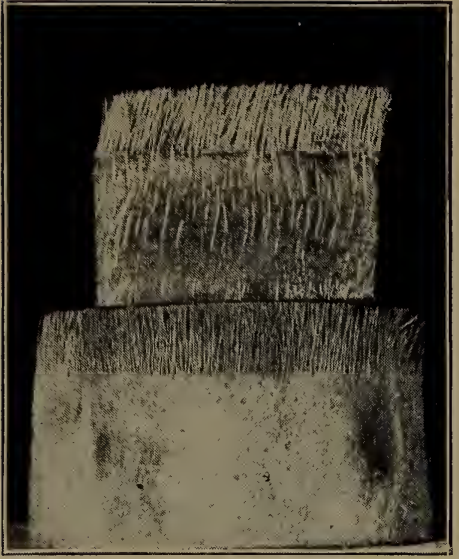

Fig. 120.

Brushes made from the stem of the saw-palmetto. The pith has been combed out and the fibro vascular bundles are tough enough to be useful as brushes. These brushes are made in Melbourne, Florida. vascular bundles. Let some of these stems have white flowers on them and see if, after a time, the red color does not appear in the veins and veinlets of the floral leaves. With a microscope the vascular tissue can be traced all the way into sepals, petals, stamens and pistils; you can often trace it all the way by the tracks of red with the naked eye. The right flower in Figure 52 was striped in this way within three hours after it was placed in the ink.

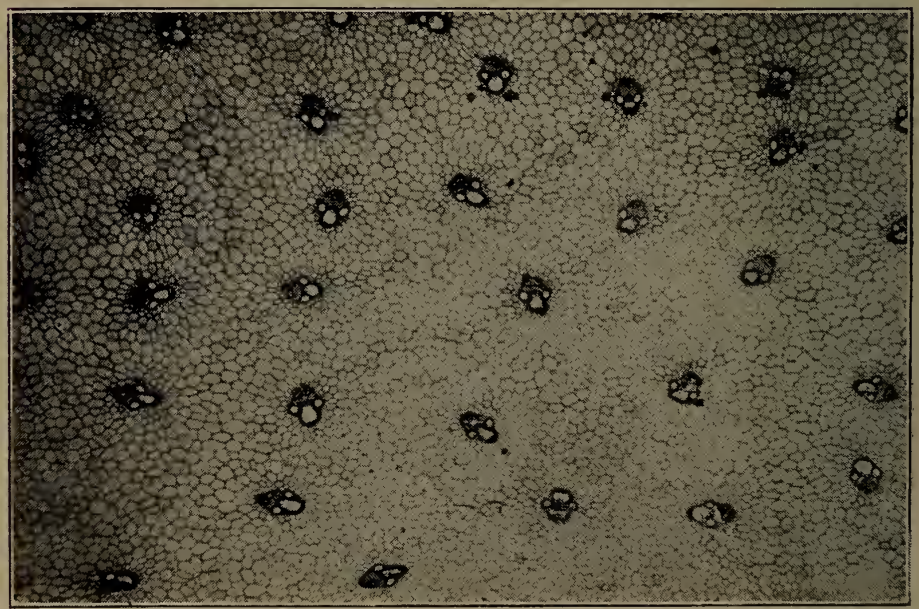

Fig. 121.

Corn bundles distributed irregula rly as in smilax and palm $\mathrm{x}^{-}$about 30 . 
Exercise II: Get a geranium leaf and break its petiole by a steady pull, but do not allow your hands to separate more than a quarter of an inch. The vascular ducts in the geranium are wound about by spiral bands tougher than the rest of the tissues; these will uncoil and the lower end of the petiole will be suspended by these coiled threads.

\section{LESSON LXXVII.}

Stems.

The Arrangement of Fibro-Vascular Bundles in Exogens.

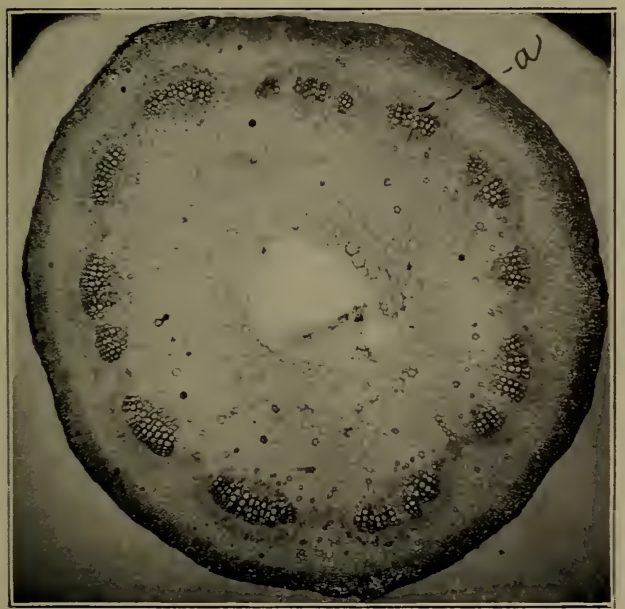

Fig. 122.

Cross-section of geranium stem. Fibro-vascular bundles in a definite circle with pith cells (medullary rays) between. $\mathrm{x}$ about 18 .
Cut across a geranium stem one year old and compare the cut end with Figure 122. The wedgeshaped bundles a, are fibro-vascular bundles. Notice that they are arranged in a circle around central pith in the geranium stem while they are irregularly s c a t t e r e d through the pith in the corn and smilax stems. This arrangement of the fibro-vascular bundles in rings is seen in all our forest trees; it is the exogenous structure, the pine structure, the oak 


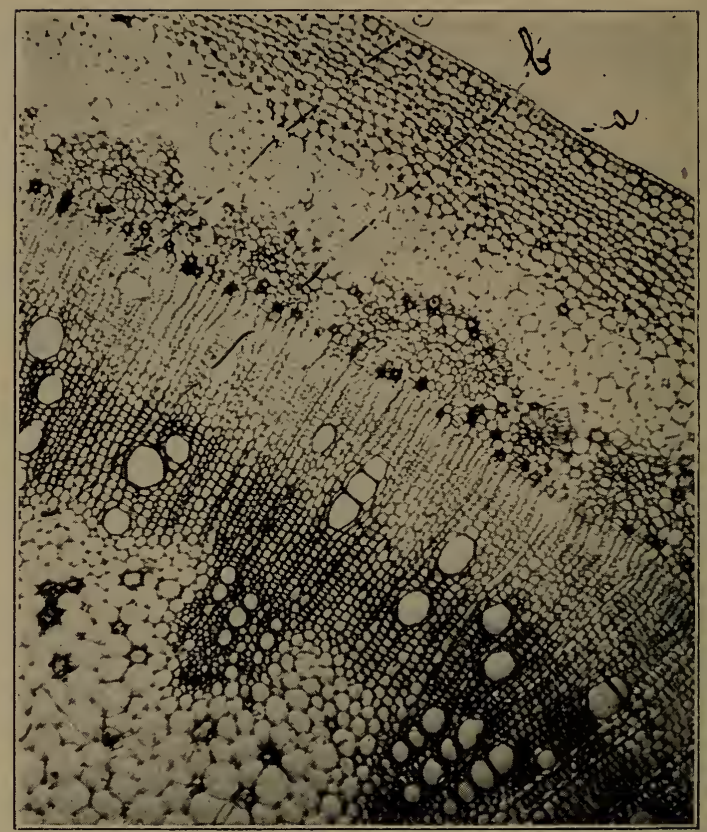

Fig. 123.

A fibro-vascular bundle of Figure 122, more highly magnified. Pith at the left, then wood, cambium $\mathrm{c}$, and outside of it the various elements of bark.

structure. Compare the next lesson. The irregular disposition of these bundles in smilax and corn pith acquaints us with the palm structure, the endogenous structure. 


\section{LESSON LXXVIII.}

\section{Stems.}

The Grouth of Wood in an Exogen.

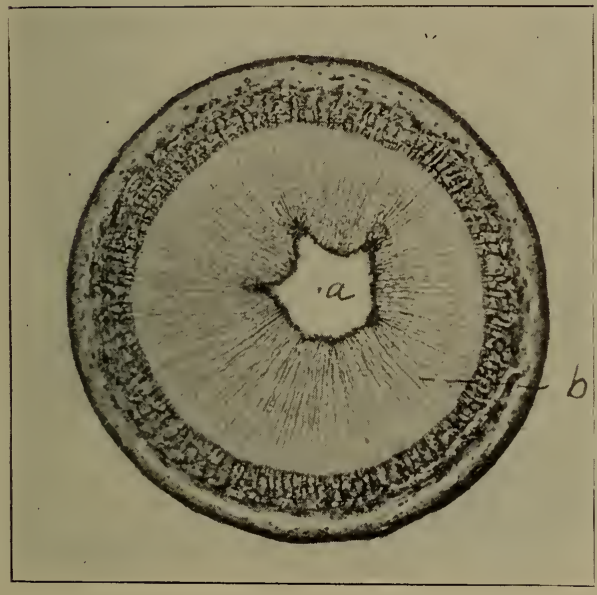

Fig. 124.

4 cross-section of a one-year-old stem. It shows from within out pith, wood crossed by medullary rays and bark. slide and photograph by Mr. George Bond. $\mathrm{x}$ about 18.

Cut across a oneyear-old stem or branch of almost any tree; Figure 124 is taken from willow. Compare your cross-section with it. There is a center of pith nearly white, a; a ring of wood made up of the woody part of fibrovascular bundles, $b$; and a ring of bark. Figure 123 shows a fibro-vascular bundle in detail and we cannot learn about growth in a tree without a little study of it. The part from c, to b, containing the large clear openings, is wood tissues; from $c$ to $\mathrm{a}$, is bark tissues. Growth occurs at c, here the wood thickens on its outside and the bark on its inside; $c$, is the cambium layer. Figure 125 is a three-year-old stem. The pith is the white center; the wood is the three definite, half-inch, light rings that surround the pith; the dark, outer portion is the bark; the lines that mark so sharply 
the divisions between the three portions of wood are caused by the fact that the cells are small and thick-walled in the fall when growth stops and large and thin-walled in the spring, when growth begins. The rings of growth accord-

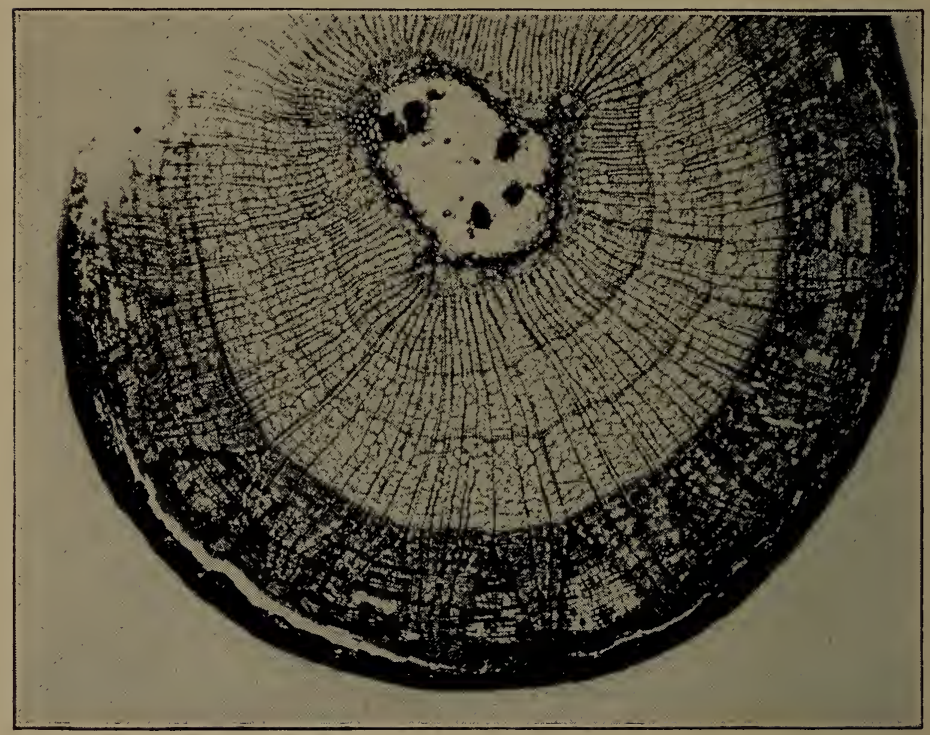

Fig. 125.

A three-y ear-old exogenous stem. It shows in addition to what Figure 124 does, the three rings of growth. $\times 18$.

ingly, however numerous they may be, are made up of circles of the wood portion of the fibro-vascular bundles, and each ring stands for one year's growth.

Exercise for a school: Saw off a section from the largest $\log$ in the neighborhood. Find out from a carpenter how to polish and varnish the end. Count the wood rings, every one of which stands for a year of growth. Now count from the outside 411 rings and mark the ring that shows how large the tree was when America was discovered; mark in 
the same way its size when Washington was inaugurated, when Lincoln spoke at Gettysburg, etc., for other impor-

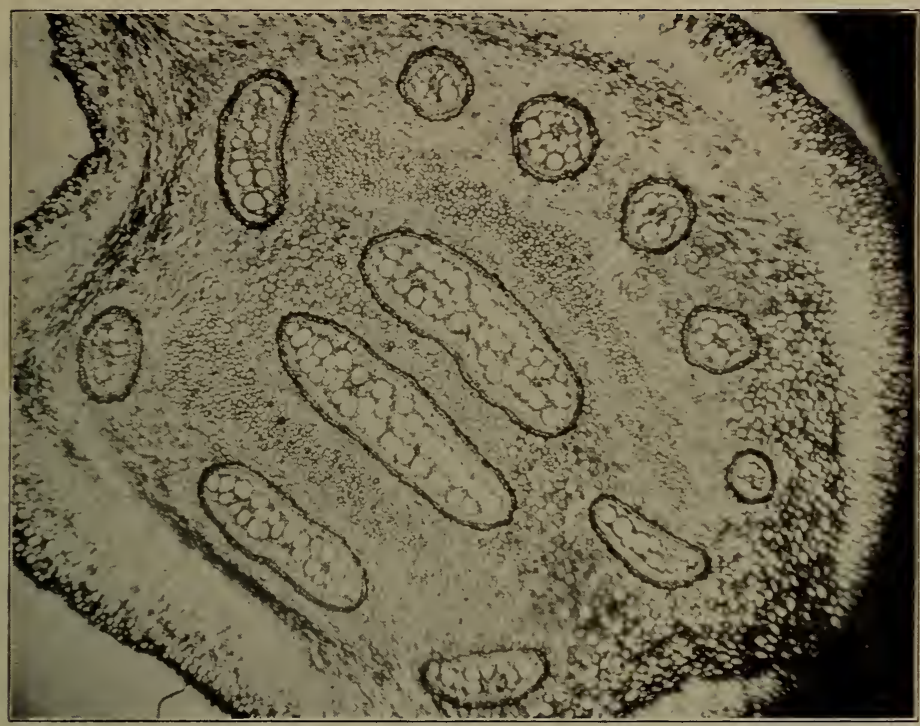

Fig. 126.

A cross-section of a rootstock of fern showing its bundle-arrangement $\mathrm{x} 18$.

tant events of our history. There is such a section of a large tree in the South Kensington Museum on which more than a thousand years of English history are chronicled. 


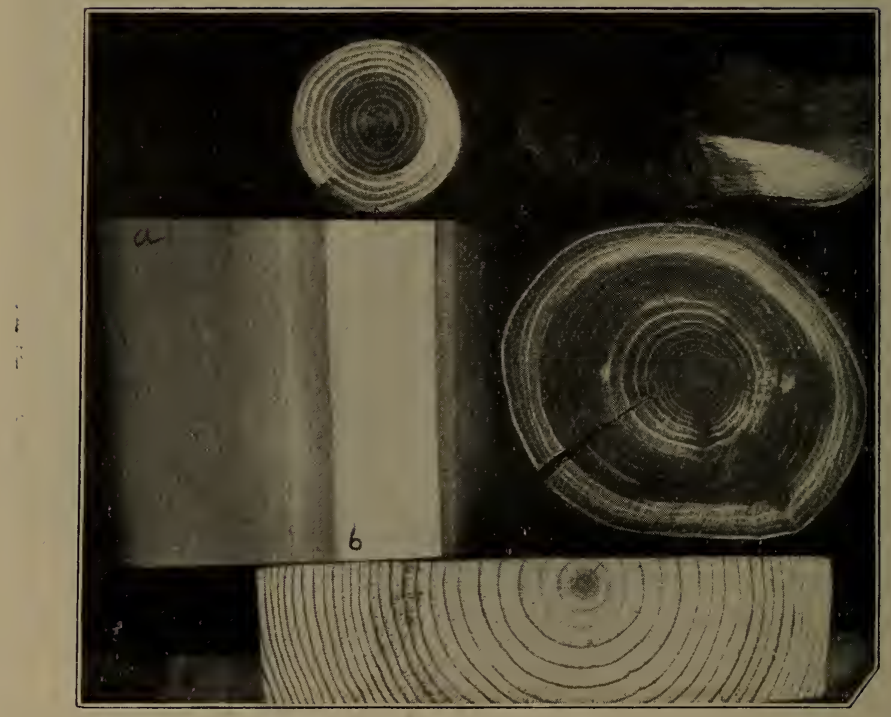

Fig. 129.

Fig. 128

Fig. 127.

Fig. 127. The heart-wood, a, sap-wood b, and bark of poplar (tulip). Fig. 128 . Rings of growth in red cedar. Fig. 129. Rings of growth in the hickory. All these above a pine board that shows rings of growth well 
Stems.

\section{LESSON LXXIX.}

\section{Stems.}

\section{Quarter-Sawed Oak.}

Notice in the cross-section of oak and mistletoe, Figure 135, upper piece, there are radiating lines which run out from the pith toward the bark. These are called medullary

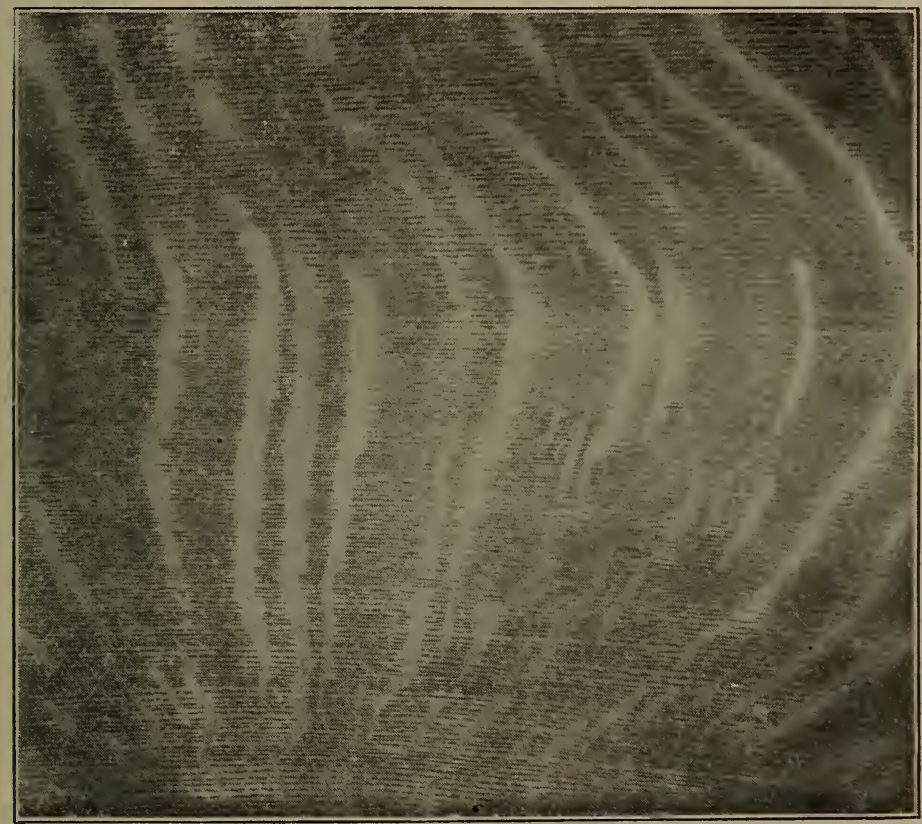

Fig. 130.

Quarter-sawed oak. The wide, perpendicular markings are the medullary rays as they appear in a radial section.

rays. Quarter-sawed oak is oak that has been so sawed that the saw passed in the plane of these rays; that is from the pith to the bark. The log is first quartered then a board or two is sawed off from the side of a quarter and 
when the grain begins to run out a triangular piece is cut off thicker at the bark so as to again bring the saw into line between the pith and bark. Figure 130 shows a quartersawed plank. These peculiar markings are caused by the medullary rays. When the tender end of a growing shoot is examined it is found to be all pith. The fibro-vascular bundles grow up later in the pith; this leaves pith cells between fibro-vascular bundles. These are the medullary rays. They do not look like the wood-cells and although single cells cannot be seen by the naked eye, masses of them can be.

In Figure 122 the pith between fibro-vascular bundles shows well the medullary rays. As these bundles become more and more numerous the medullary rays become narrower and narrower; the radiating lines in Figures 124 and 125 show medullary rays as they appear in cross-section.

Exercise: Sketch medullary rays as they appear to the naked eye in cross, radial and tangential sections of some wood. A radial section is made when the knife or saw extends from the pith to the bark. A tangential when it is at right angles to a line from pith to bark.

\section{LESSON LXXX.}

Stems.

\section{Heart-Wood.}

Find a tree somewhere that is hollow at the butt and yet is still apparently growing and healthy. The wood usually found at the tree's center, and that has rotted and disappeared in this case, is the heart. See Figure 127 for the heart-wood a, the sap-wood b, and the bark of the poplar, (tulip). If you are not perfectly familiar with heart and sap-wood, cut into a tree or large limb and see the difference in color of the two. Notice that the sap-wood is softer 
than the heart-wood; it is also lighter; the reason for this is the tissues of the sap-wood are younger and thinner walled. The heart-wood is not alive.

Layer by layer the wood-tissues grew when the tree was young as explained in Lesson LXXVIII. The innermost

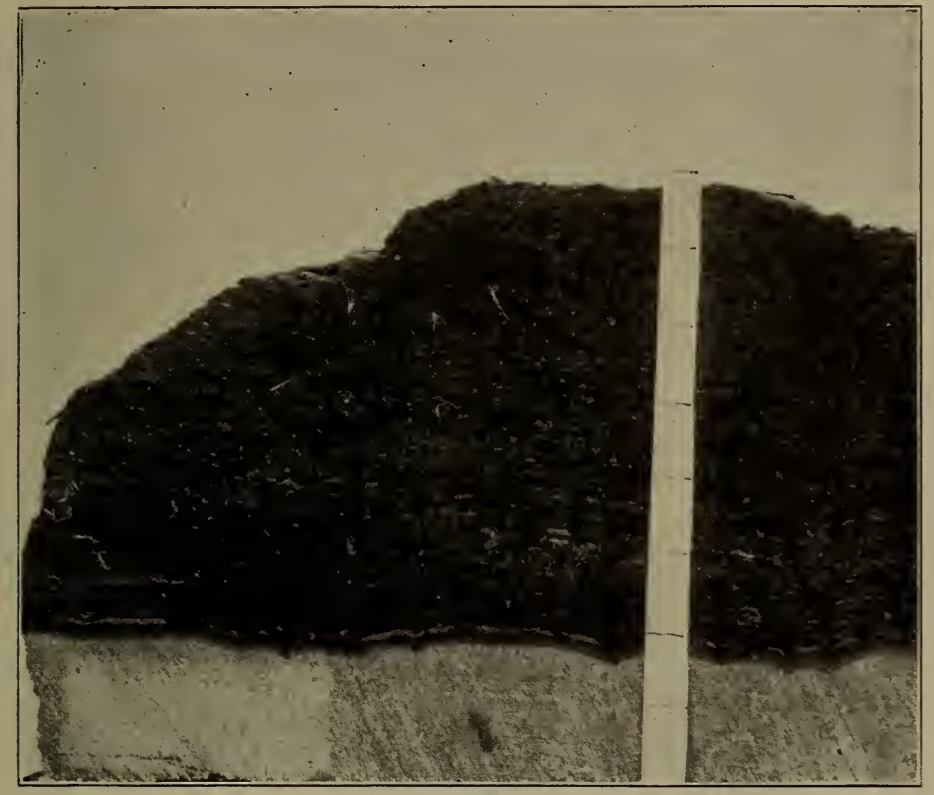

Fig. 131.

Bark of Sequoia. In this piece it is six inches thick. The marks on the white strip are one inch apart.

layers were of course the older. Finally layer by layer it began to die on the inside, as it grew on the outside. Life and death have thus followed each other from within out, always separated by about the thickness of the sap-wood. Holmes says:

"In fact there's nothing that keeps its youth

So far as I know but a tree and truth." 
It would seem from the above that a tree does not keep its youth. Life is confined to a narrow zone on the inside of the bark and the outside of the wood. The heart is the ancestry of the living wood; the dead outer bark of the living bark. The wood entombs its forefathers; the bark in one way or another sheds them. The entombed heartwood strengthens the tree against storms. The bark dead, but not yet shed, protects it against blows and cold and heat and wet and bark-eating animals. Figure 131 shows the bark of the Sequoia gigantea, the big tree of California. This specimen is six inches thick.

Exercise: Determine the number of years of growth of any tree; wet or varnish a smooth cross-section and you will be able to count its rings of growth.

\section{LESSON LXXXI.}

\section{Stems.}

\section{Stem Disguises.}

A stem bears leaves, and roots grow out from it. These offices declare a vegetable stucture, a stem. It does other things, as for instance, it serves as a storehouse for food; other parts of the plant do this also; but only a stem bears leaves and roots. Armed with a dictum like this we can recognize it under its varying forms. Figure 55 shows an underground stem. It has its advantages in the struggle with frosts and storms and rabbits; but the giants of the vegetable kingdom have got on otherwise. This was not a winning way. The stem is prostrate on the ground sometimes; this is the case with the stem of the saw-palmetto; 
it floats under water sometimes, as in the case of Chara; it climbs by many methods, but all climbers are dependent. The princes of the vegetable world relied on none of these methods. At great expense to themselves they stand among their equals. The vine can only go where the oak has first gone.

Exercise: Find the stem of fern, Solomon's-Seal, bloodroot, violet. Is the Irish potato a stem or root? the sweet potato? the artichoke? the Indian turnip? Those are stems that bear buds or leaves.

\section{LESSON LXXXII.}

\section{Stems.}

Why the Yellow Violet Comes so Early in the Spring.

"Of all her train the hand of Spring

First plants thee in the watery mould,

And I have seen thee blossoming

Beside the snow bank's edges cold."

Our common violet blossoms early also. The goldenrod does not bloom until autumn. We are entitled to ask why; but the plants themselves are the only authority on the subject.

Exercise: In early spring, gather the following flowers, dig every one up by the roots: Spring-beauty, windflower, liverleaf, pepper-and-salt, lamb's-tongue, trillium, violet, bloodroot, crowfoot and twinleaf, and any other kind of flower you can find blooming with or before them. Do they all grow from bulbs or thickened rootstocks or roots? Some underground source of nourishment? Can this be the reason why they can bloom so early? Does the crocus come early and from a bulb? Does the tulip? Does the lily-of-the-valley come from a rootstock?

Provided as all these plants are with nourishment on 
which to grow they can bloom at once as soon as spring opens. Starting with only the patrimony of a small seed, of course the ragweed must have a long time in which to develop green leaves and roots and gather the necessary food for the exhausting process of seed-bearing. It should further be noted that all these spring flowers are content with small stature. If they wasted their substance in growing large stems they could not bloom so early.

But why should these spring flowers be in such a hurry? Several considerations are worth while in answer. If all plants grew at once and in similar places, there would not be room for them all. Where do you find these little spring flowers? Is it not in the woods and before the trees get their leaves? They must make hay, their flowers and seeds, while the sun shines. Three weeks later and they could not see the sky at all. It is by fitting in to this one little niche of place and time that they can live at all. Patrimony, haste and smallness give us the fleeting beauties of our April days.

You may sometime visit a tropical forest, that is always green and growing and so forever casts its dense shadow. You will find no spring-beauties or any other kind of flowering herb there. Everything that flowers, has had to climb as the forest climbs. Instead of small shrubs and annual herbs, you will find vines that can mount up to sunlight on the top of an Amazonian forest.

\section{LESSON LXXXIII.}

\section{Stems.}

Bark.

If the birch tree is in your neighborhood notice that the bark easily strips off in horizontal strips. Find a shagbark hickory and notice that its bark peels off in vertical strips 
that come loose first at the bottom. (Is this to make climbing the tree difficult for the protection of the nuts?) Notice that the sycamore occasionally sheds its bark and comes out in a new dress. What is cinnamon? Notice the ironwood and see that its bark is shredded up and down the stem, the strings being very fine. Notice the bark of the sour-gum, persimmon, sugar, elm, oak, locust and walnut and see if they are not variously cracked and split up. How many trees can you tell by the bark? It would be fine nature study work for you to learn to tell them all this way.

Why is the bark not as thick as the wood if a layer grows every year, as explained in Lesson LXXVIII. Why does the bark split on the tree in these various ways? The tree has a bark when it is very young. Its outer bark is dead; as the tree grows would it not be obliged to split? The bark of some trees clings much longer than that of others, but sooner or later and for one cause or another, the outer bark of all trees is lost.

Exercise: Compare for thickness of bark red-oak, sugarmaple, beech, walnut, tulip and sycamore; trees of about the same size should, of course, be selected.

\section{LESSON LXXXIY.}

\section{Stem Structure.}

\section{Ashes.}

Every one knows that when we burn wood we have ashes left. Ashes consist of minerals of one sort and another. In the pioneer days there was a "hopper" at every house, in which ashes were leached to get "lye" for soap making. The "lye," "alkali," "potash" of the ashes acts on the grease in such a way as to make soap and glycerine. We sometimes, when rainwater is scarce, make use of ashes to soften hard water, that is, to take the lime and magnesia out. 
The mineral matter of plants is absorbed from the soil in the water. The water escapes in transpiration and leaves the mineral matter behind. Consult again the lesson on transpiration, Lesson XLI. All summer long water, containing mineral matter, is absorbed by the roots of plants and given off in the form of vapor by transpiration, leaving considerable quantities of minerals in the plants. The same quantity of beech leaves burned in October will leave two and a half times as much ashes as if burned in May. Plants cannot grow and mature if they be deprived of these minerals; that is, if they are supplied only with distilled water. Plants deprived of potash lose the power to make starch. If they are deprived of iron the green coloring matter does not work properly. The living matter in plants always contains phosphorus and sulphur. We do not know all the duties of all the minerals in plants. Scouring-rushes owe their roughness to silica in the stem. This protects them somewhat from animals that would eat them. Some grasses are protected in the same way.

\section{LESSON LXXXV.}

The Root.

The forms of the root are simpler than those of the stem. Why is this so?

The turnip, the radish, the parsnip, etc., have one main descending root called the tap-root with subordinate branches. Other plants have many co-ordinate roots growing out from the stem in all directions. Roots are sometimes thickened and contain nourishment stored up for the plant the following year, as in the case of the carrot, rhubarb, etc., or for new plants as in the case of dahlia or sweet potato. It may give us some trouble to determine whether these underground forms are stems or roots. If they bear 
buds like the Irish potato and artichoke, they are stems. If they bear leaves like the onion, lily and the rootstocks of ferns, Solomon's-seal, and bloodroot, they are stems.

Another office of the root is to hold the plant to the soil or other support. The power of the root to force its way through the hard earth is remarkable. The acirancing root

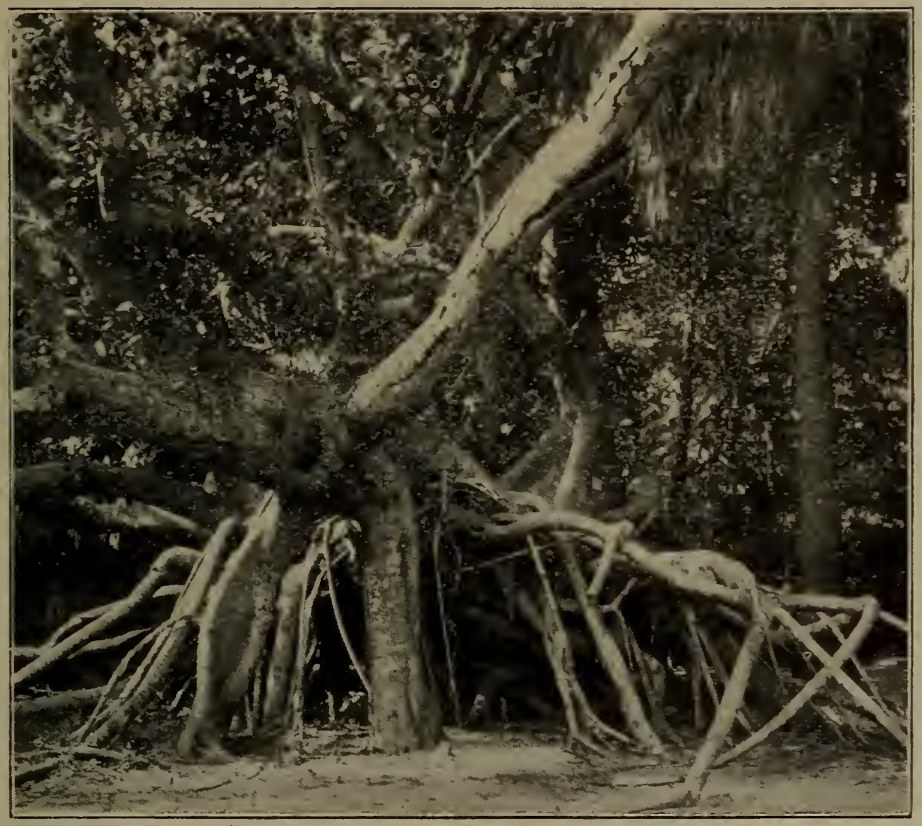

Fig. 132 .

Aerial roots of rubber-tree, Palm Beach, Florida.

is preceded by a root-cap which protects the growing point as it advances and penetrates the earth in its front. The poison ivy is held to its support by aerial roots that grow from the stem above ground. Aerial roots may be seen in Indian corn, in the rubber-tree of Florida, Figure 132, and in the famous and everywhere pictured banyan of India. 
The roots of this tree descending from branches form additional trunks so that one tree may make a colony covering as much as ten acres.

Still another office of the root is to absorb moisture; this is done by the young root-hairs which are produced continually on the younger parts of growing roots. These hairs come with the leaves and possess in the aggregate a surface in proportion to the leaf surface. This is why it is so difficult to successfully transplant a plant in full leaf. The absorbing root surface is lessened greatly by the injury to root-hairs, while the transpiring leaf surface remains the same. If plants are transplanted in the fall or spring, only so much leaf surface is called out when the growing time comes as corresponds to the root-hair absorbing surface.

\section{LESSON LXXXVI.}

\section{Why Clover Helps the Soil.}

It has long been known that clover rejuvenates the soil. Farmers sow it in worn-out fields. The reason why this enriches the soil has been lately found out. Bacteria live in the tubercles, Figure 133, that grow on the roots of the pea, vetch, clover and some other plants. They have power in their growth to take nitrogen from the air for food; no plant or animal can live without nitrogen. When this becomes scarce in the soil ordinary green plants cannot grow well as they cannot take nitrogen from the air. It is equally true that no living thing can exist without carbon. Bacteria, as has been shown, cannot get this from the air. The bacteria growing in the clover root give us a fine instance of symbiosis; the clover takes necessary carbon from the air for both itself and the bacteria. The bacteria take the necessary nitrogen for both themselves and the clover 
and when the clover is plowed under, all the nitrogen of both is handed back to the soil in their decay.

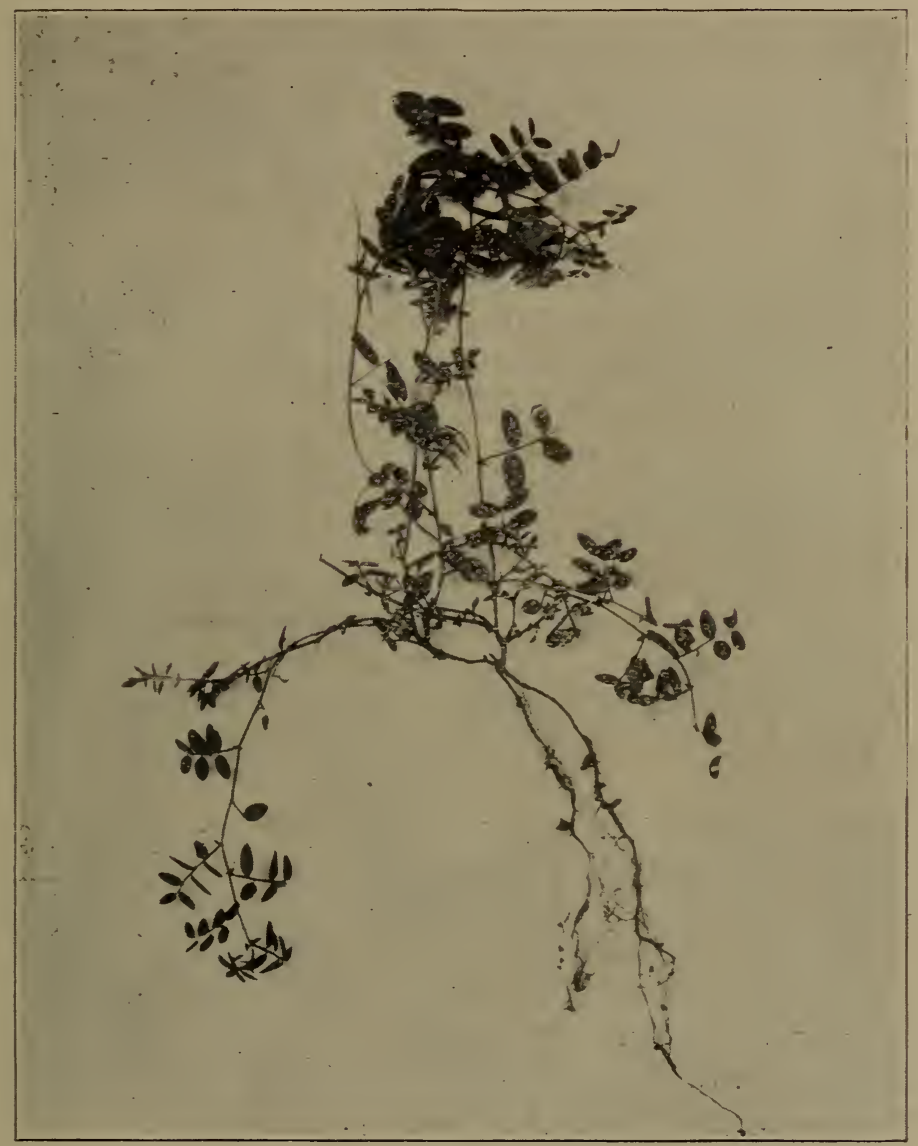

Fig. 133.

Vetch showing tubercles on its roots in which bacteroids live.

Exercise: Find these tubercles on the roots of clover, vetch or some other leguminous plant. 


\section{LESSON LXXXVII.}

\section{Uses of Plants.}

\section{Plants and Starch.}

We owe all our starch to plants. We obtain it from the seeds, stems, roots and leaves;our main supply comes from seeds. It is very easy to detect starch; it turns blue or black when treated with a solution of iodine.

Starch is insoluble in cold water; a seed may therefore get wet and dry without loss to its food supply. Plants, however, cannot take solid food; but starch is easily converted into grape-sugar, which is soluble. In every seed is a ferment which at the right temperature and moisture can affect this change. The brewer takes advantage of this; he sprouts his barley and corn and lets the young plants turn their supply of starch into grape-sugar; then before the growing embryo can feed on it he raises the temperature and kills the embryo. But suppose the embryo is not killed; then the liquid grape-sugar which the plant has made, flows to every part of it and is by its vital action converted into cellulose, the main substance of which wood is composed. Cellulose has exactly the same composition as starch. Six parts of carbon and five of water make starch: an insoluble, pulverulent powder. Six parts of carbon and; sixof water make grape-sugar; an easily soluble and therefore for the plant, easily transportable, substance. Six parts of carbon and five of water make cellulose, an insoluble substance, strong and durable as oak. Any one who has any penchant at all for

"Admirin' 'ow the world is made."

ought to quite master this adaptation. Starch is an insoluble substance that can be packed away in any available crevice. Properly add one part of water and it becomes 
soluble and can go to any part of the growing plant. When it gets to any desired part properly subtract 1 part of water and it becomes tissue, without which the plant as we know it, could not be. Sugar-cane is known nearly everywhere. If it were cut earlier it would contain starch only. Later its sugar would have gone to starch again in the seed, and to cellulose in its cell-walls.

Exercise: Get of your druggist four grains of potassium iodide and one grain of iodine dissolved in an ounce of water. Boil a little starch in water and put a drop or two of the iodine solution in the starch solution; it will turn blue. Now instead of the solution of starch, make a solution by boiling pounded grains of wheat, corn, oats, rye, rice, or bits of tapioca, in water. A drop or two of the iodine solution will turn any of these solutions also blue. Any seeds may be tried this way.

\section{LESSON LXXXVIII.}

\section{Uses of Plants.}

\section{Plants and Food.}

Of the three different kinds of food that we require, starch and sugar come entirely from the plant world. Our main supply of fats comes from animals; plants nevertheless furnish us much. Linseed-oil comes from flaxseed. Palmoil from the palm tree. Castor-oil from the castor-bean. Sweet-oil from the olive. The main supply of vegetable oil comes from seeds. Hickory-nuts contain much oil. Sections of the Brazil-nut under the microscope, show a large percent of oil. Peanut butter is now everywhere a commercial article. The manufacture of cotton-seed oil is a large industry.

What do you know of the beet-sugar industry? Of the 
sugar-cane industry? Of "home-made sugar," the maple molasses industry?

The third necessary food-stuff is protein. One main supply is from lean meat, but all sorts of grain give large quantities. The living part of the grain consists entirely of protoplasm and there is always protein stored up as food for the embryo in the seed. The inner cells of a grain of wheat are filled with starch, the row next the bran contains protein entirely.

Plants contain every kind of food necessary for life. Mushrooms consist almost entirely of protoplasm.

Exercise: Put a little of the iodine solution mentioned in Lesson LXXXVII on a bit of mushroom; it will stain it from yellow to brown according as the solution is weak or strong. It stains it the same color as it does your skin. Both are made of protoplasm. Many people eat mushrooms, but as there is a kind that is poisonous, no one should ever eat them unless he knows he has an edible variety.

\section{LESSON LXXXIX.}

\section{Uses of Plants.}

\section{Plants and Clothing, Medicine, etc.}

How many articles are you wearing now that are made of cotton? Find out how much cotton we raise in a year. Exchange greetings with a school in Georgia and get a cotton plant in return for some northern plant. Read the story of Eli Whitney. Raise cotton from the seed.

Find out from the oldest man in the community all about flax, flax breaking, hackeling, spinning and weaving. Read a description of the hemp industry in James Lane 
Allen's "Reign of Law." Study the straw hat industry; at least we know that plants furnish the straw.

It has also been shown that plants furnish us every sort of food we require, sugars, fats and albuminoids. They furnish us also an almost endless list of essences, condiments, stimulants, narcotics and poisons. Among these and in addition to them they furnish us many medicines. Treatises are written o:n this subject and courses of lectures are given on it in universities and medical schools. We are all acquainted with the use of slippery-elm bark, yellowroot, ginseng, and sassafras as medicines; some parts of many of our common plants are so used; may-apple, wild cherry, poke-root, Datura (jimson-weed Elecampane,,) etc. Many organic acids come from plants; citric from the lemon, tartaric from the grape, malic from the berries of the mountain-ash, and acetic from apples, grapes and many other sources. Wood-alcohol comes from beech wood, ordinary alcohol from grains and many other sources, and a large number of other alcohols are derived from plant products. The acids above named often combine with the mineral elements that come up from the soil and form crystals in the cells.

\section{LESSON XC.}

\section{Uses of Flants.}

\section{Lumber and Fuel.}

How many kinds of trees grown in your neighborhood are sawed into lumber? How many are cut into shingles? Which are used for fence posts? for telegraph poles? for barrel staves, heads and hoops? for ax handles? which for mallets and mauls? which are steamed and bent into bushel measures? which are generally cut for fuel? which furnish 
twigs for baskets? Gather a bundle of willow twigs. Notice that they are very brittle at the base and break off easily; but that they are everywhere else tough and flexible. We can study the uses to which plants are put and from these we can infer their properties, or we can study their properties and make out from this study the uses to which they may be applied. Which wood is used for furniture, and which is hard and will take a polish and is beautiful when finished, are questions that have the same answer. What forest-trees are most used for shade-trees is one with asking which are the most beautiful or of quickest growth or cast the finest shadow. Let the poplar and oak stand for the houses we live in. The sugar and beech for comfort in the home. The cotton and flax for clothing. The wheat and corn for food. The elm and sassafras for medicine and Whittier's "Palm" is not fable:

"Is it the palm the cocoa-palm,

On the Indian Sea by the isles of balm?

Or is it a ship in the breezeless calm?

"A ship whose keel is of palm beneath,

Whose ribs of palm have a palm-bark sheath,

And a rudder of palm it steereth with.

"Branches of palm are its spars and rails,

Fibres of palm are its woven sails,

And the rope is of palm that idly trails!

"What does the good ship bear so well?

The cocoa-nut with its stony shell,

And the milky sap of its inner celi.

"What are its jars so smooth and fine,

But hollowed nuts, filled with oil and wine,

And the cabbage that ripens under the Line?

"Who smokes his nargileh, cool and calm? The master, whose cunning and skill could charm

Cargo and ship from the bounteous pa.lm.

"In the cabin he sits on a palm-mat soft,

From a beaker of palm his drink is quaffed,

And a palm-thatch shields from the sun aloft!

"His dress is woven of palmy strands,

And he holds a palm-leaf scroll in his hands,

Traced with the Prophet's wise commands!

"The turban folded about his head

Was daintily wrought of the palm-leaf braid

And the fan that cools him of palm was made. 


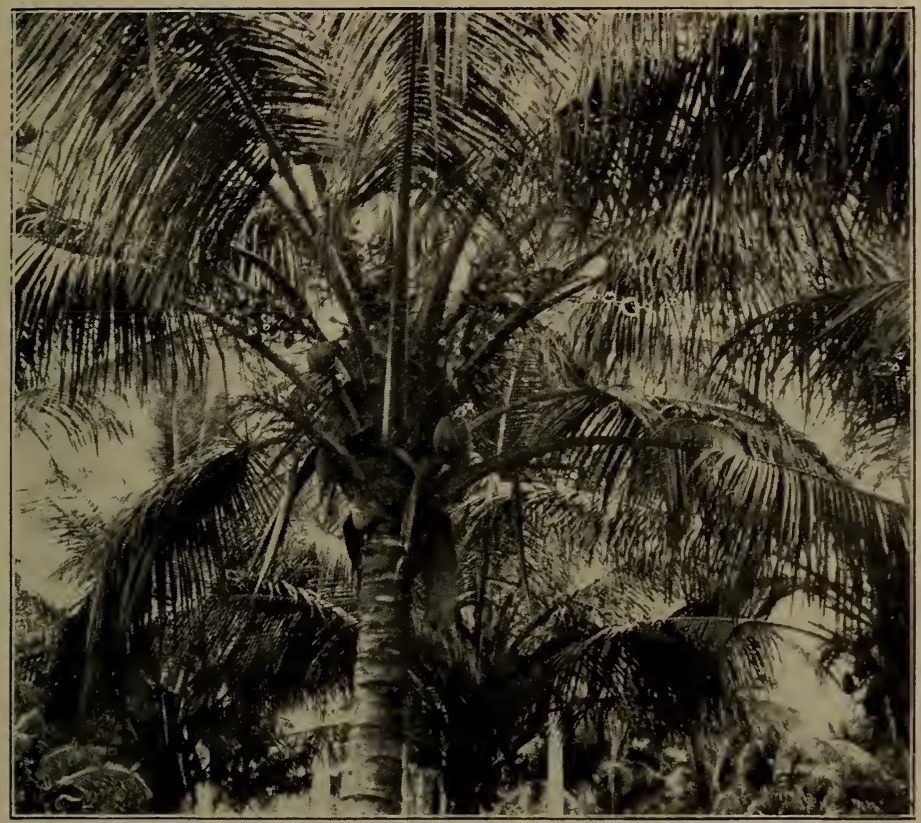

Fig. 134 .

"Of threads of palm was the carpet spun

Whereon he kneels when the day is done,

And the foreheads of Islam are bowed as one:

"To him the palm is a gift divine,

Wherein all uses of man combine,-

House, and raiment, and food, and wine!

"And, in the how: of his great release,

His need of the palm shall only cease

With the shroud wherein he lieth in peace.

.. 'Allah il Allah!' he sings his psalm,

On the Indian Sea, by the isles of balm;
"Thanks to Allah who gives the palm!":;"

Exercise: What plants do for us all the things the palm is said to do for the Indian? 


\section{LESSON XCI.}

\section{Parasitic Plants.}

Many plants cause disease in other plants by growing on or in them and living at their expense. Every one is familiar with the heads of black smut that live on wheat, oats

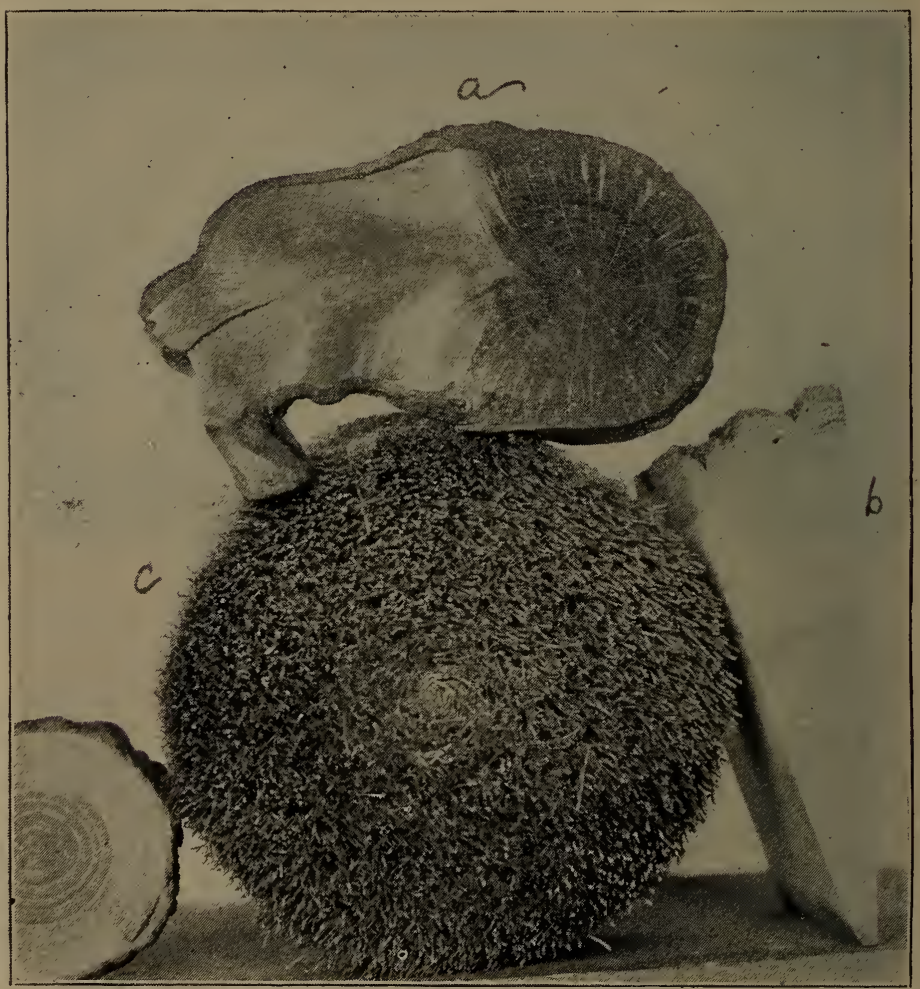

Fig. 135.

a. A section through a branch of mistletoe growing on oak; the mistletoe is to the left, the oak to the right. Mistletoe is a green-leaved parasite, lives on crude ascending sap it gets from the oak's fibro-vascular bundles. Chlorophylless parasites strike through the bark only and live on the living matter of the plant in the cambium layer; b shows an end view of Figure 127. c is a palmetto:brush giving an end view of the listles (fibro-vascular bundles). 
or corn. The shepherd's-purse that grows everywhere is often infested by a white rust; this same rust grows on radishes and causes the blossoms, seeds and leaves to swell greatly by the multiplication of its organs of reproduction within the tissues of the radish.

Cluster-cups, very beautiful under a low power of the microscope, grow on gooseberry and other sorts of leaves.

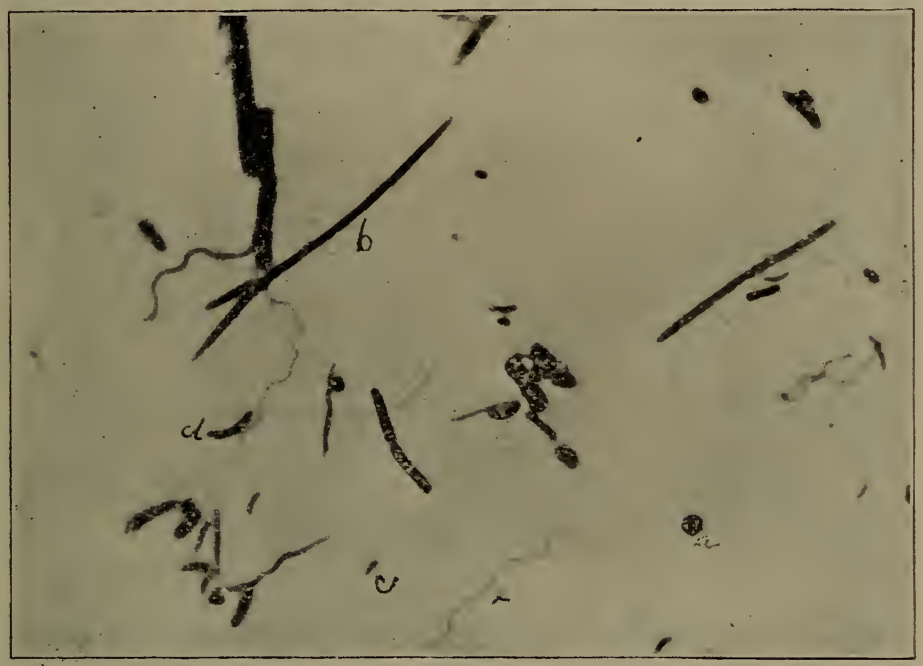

Fig. $1: 6$.

Forms of bacteria; a, globular; h, a long rcd; $c$, a : hort rcd; d, a kent rcd; e. a spiral. $\times 2000$.

Lilac leaves are often covered by a grayish powder which is seen under the microscope to be a parasite. Blackberry leaves are often covered with a red rust which is a parasite. A study of these plants requires a knowledge of how to use the microscope, but their large colonies can usually be scen with the naked eye and we should learn how to recognize their presence in this way.

The disease germs known as bacteria, are microscopic 
plants. Figure 136 shows four different forms which they assume; they are globular, like $a$; long rods, like $b$; short rods, like $c$; bent rods, like $d$; and spirals like $e$. This photograph was made from tooth scrapings.

Figure 138, shows the bacillus that causes consumption. It was discovered in 1881 by Robert Koch, a German bac-

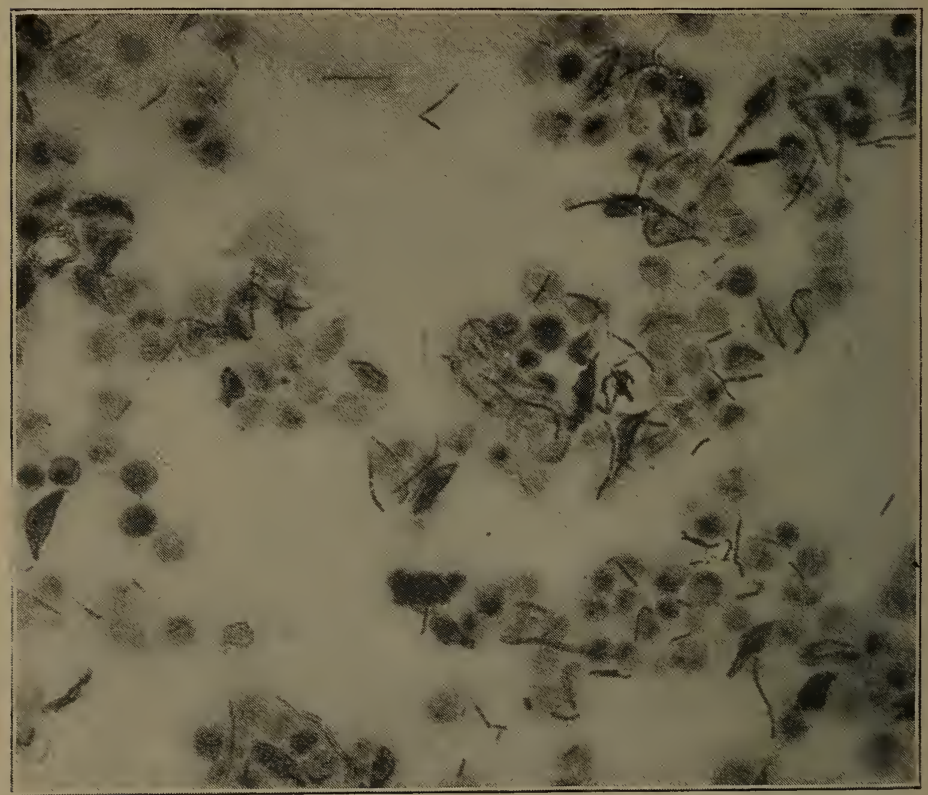

Fig. 137.

Anthrax being devoured by the white blood-corpuscles of a frcg. $\mathrm{x}$ about $4 \mathrm{CO}$.

teriologist. He has made it possible for us to make a certain diagnosis of this disease in its earliest stages and in many cases to arrest its development. Some knowledge of his life and labors should be known to every one.

Figure 137 shows the bacillus that causes splenic fever in process of being devoured by the white corpuscles of a frog's 
blood. A mouse if inoculated with this bacillus, dies of the disease. A frog does not contract it at all; the reason seems to be that the white corpuscles of the frog's blood eat these bacilli up. This bacillus forms spores when conditions for its living become unfavorable, as when its food begins to give out. These spores are able to resist a degree of heat and cold, which the bacillus cannot; these spores serve it as

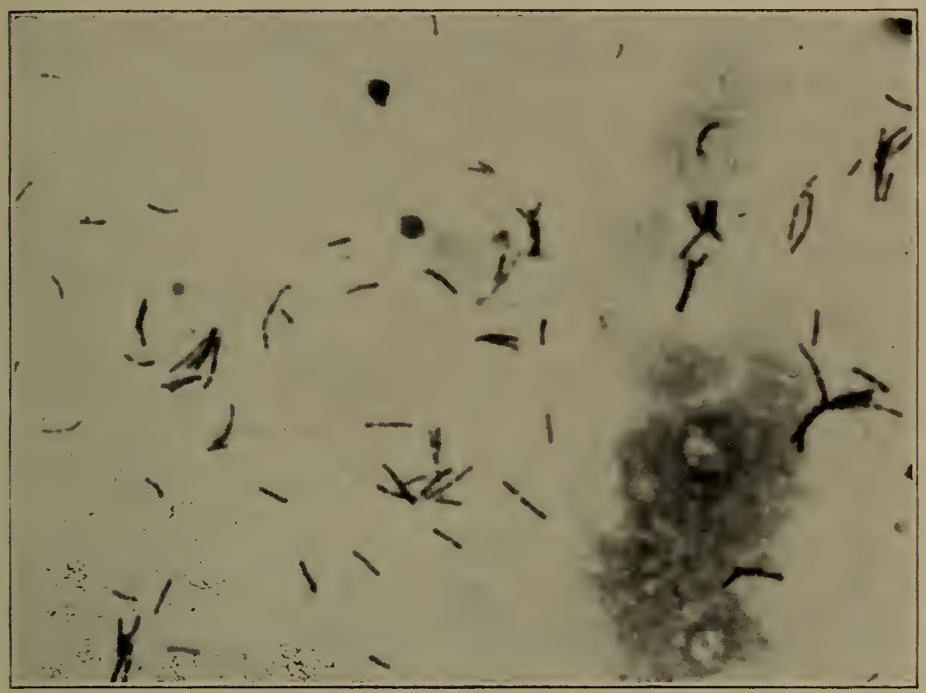

Fig. 138.

The long jointed rods are consumption germs. x 2000 .

the spores and seeds of higher plants serve them, that is, they enable it to survive extremes of heat, cold or dryness, which the bacillus itself could not. We owe to Pasteur, a French bacteriologist, the conquest of this disease, of the chicken cholera, of the silkworm diseases, and of hydrophobia. It was his work that first gave us the cause of fermentation and decay.

Read the "Life of Pasteur" by his son-in-law, V. Radot.

Parasitic plants should be distinguished carefully from 
epiphites; that is, plants which grow on but not into other plants. Epiphites owe support only to their hosts. Parasites owe sustenance also to their hosts. Tillandsia, Spanish moss, so common in Florida, is an interesting example of an epiphite.

\section{LESSON XCII.}

The Plant's Chief Work. Saprophytic Plants.

A plant is a machine for storing the energy of the sunlight. We can consume the plant, and its stored energy gives us strength; we can burn it in our fires and it gives us heat, which we can utilize to warm our houses or to do our work or to give us light. Coal is the plant-stored energy of past ages; this distinctive plant duty, the storing of energy, is done only. by green plants. Many plants have, however, become degenerate by feeding on organic food and leaving off entirely the storing of sunlight. Mushrooms, Figure 139 , are among such plants. They cannot grow on a mineral soil as green plants can. They do not need the light as green plants do. Mucor, the white mould one sees so abundant about stables, on foggy, wet summer days, grows vigorously in the depths of Mammoth cave, where no ray of light ever comes. These plants are destructive; they spend only; green plants are constructive; they make far more than they spend. This is the green plant's mission in the world. They constantly accumulate beyond their own needs what animals and chlorophylless plants spend.

Exercise: Go to a small stream in midsummer a half mile or so below a sewer mouth and note what grows in the water all the way up to and into the sewer. You meet first green and brown algae, scums and microscopic plants; next you see deep blue green plants in large masses; they are Oscillaria, mainly; they often so cover the bottom as to make the water appear black. You then find near the 


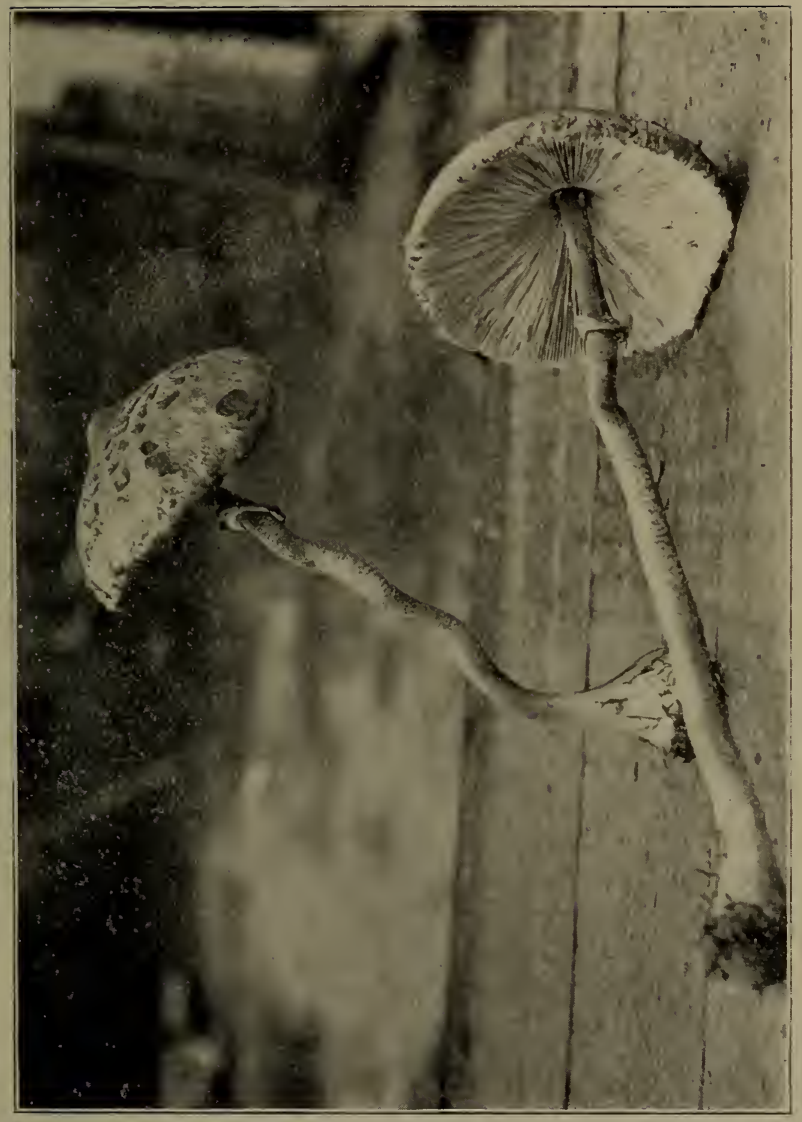

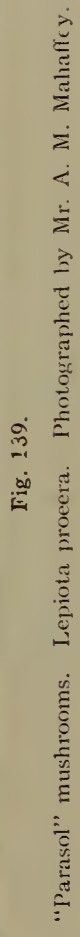


sewer's mouth and as far in it as you can see, white streamers that live on the decaying matter contained in the sewer water.

The mushroom and its allies are degenerate plants. They are not doing plant duty. If they live on living plants or animals, we call them parasites. If, like the mushroom, they live on decaying vegetation, or other dead organic matter, we call them saprophytes. The mushroom has chosen the line of least resistance which cannot be chosen by plant, animal or man, except at the expense of its birthright. The oak faced the strenuous life; the mushroom dodged it. Read the introduction to Hawthorn's "Scarlet Letter."

\section{LESSON XCIII.}

\section{Chlorophyll.}

The general green color of leaves is due to green granules in the cells. Figure 56 shows these granules. They are living bodies; they increase by division just as many low forms of life do. They are simply colored protoplasm. Alcohol will extract their color from them after which they can be stained other colors. The upper side of the leaf is greener than the lower because, for one reason, these granules are far more numerous on the upper side. They are so small that they can be seen with a compound microscope only. They can be well seen in leaves of moss simply by mounting the leaves in water. They can, of course, also be seen in all sections of green leaves or of other green parts of plants. They are very fantastically shaped in some of our commonest green pond scums, Figure 140.

The chlorophyll granules are the starch makers. They sometimes contain so much starch that a solution of iodine colors them so deeply as to mask their green. Starch is 
composed of carbon and water. These are in some unknown way brought together in chlorophyll granules. The carbon comes from the carbon dioxid of the air. The process is named from three Greek words, which mean a putting together in sunlight, photosynthesis. We ought sometime, to see these little granules, and find out how incalculably, unthinkably numerous they are in a single tree and to remember that it is to their combined action that the earth's organic upbuilding is due.

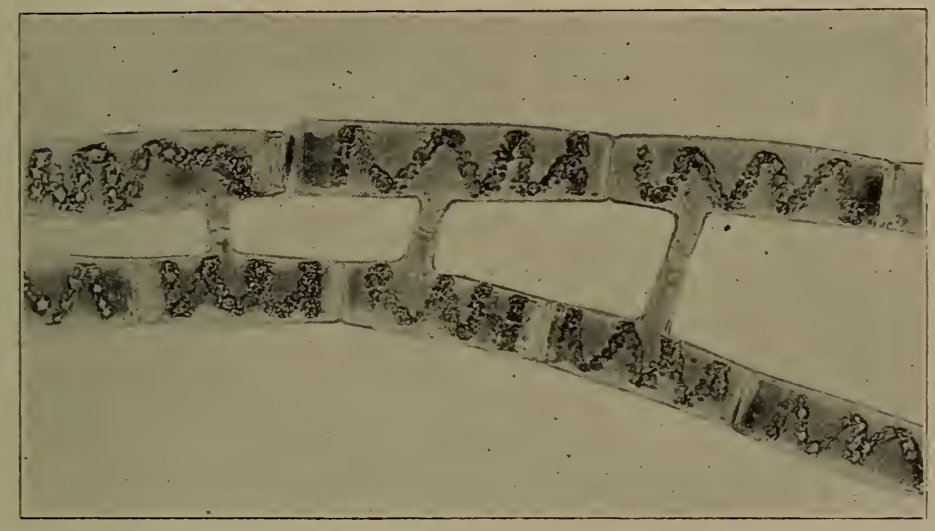

Fig. 140.

Filaments of Spirogyra getting ready fcr conjugation. The flaments can adapt themselves to the distance between them by length of tube. $\mathrm{x}$ about $1 \mathrm{CO}$.

Exercise: If the following experiment is difficult of performance, nevertheless it will help us to understand how it is learned that starch is made in the sunlight by the green leaf. Immerse a leaf from a potted plant, in Shimper's solution, see below, at about 2 o'clock p. m., and notice that it gives a starch color; the leaf should have been all morning in the sunshine. Keep the same plant in the dark from onc. morning until 2 o'clock the next afternoon and then im merse a leaf in Shimper's solution. It will show no starch 
at all, or very little. Now take a leaf and darken a spot on it between two slices of cork, thus, Figure 141, from 10

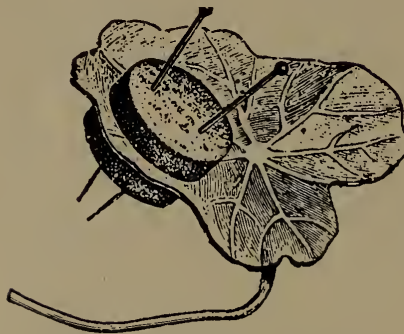

Fig. 141.

Method of shading a spot on a groiving liea ibetween I pieces jof cork. Atter Detmer.

o'clock until 2 the next day, keeping the plant all the time in the sunshine. Immerse this leaf as before in Shimper's solution and the starch color will show everywhere except in the spot covered by the cork, which had been in the dark.

Shimper's solution: Dissolve 8 grams chloral hydrate in $5 \mathrm{cc}$ of water and add to this $1 \mathrm{cc}$ of iodine solution; see Lesson LXXXVII for the formula of this solution.

\section{LESSON XCIV.}

\section{Protoplasm.}

- Differences Between Animals and Plants.

If one considers a cow and a tree the difference is plain enough; one is fixed, the other can come and go; one absorbs liquid and gaseous food only, the other can take solid food into its body and by processes of its own, reduce it to a liquid state; one can live on inorganic food alone, that is, what it gets from the ground, water and air; the other must live on organic food. The plant utilizes and stores the sun's energy; the animals utilize the energy of other animals or plants. The cow has a specialized nervous system. She knows, feels and wills. The tree seems to lack these things. These manifest differences between plant and animal life at their extremes all vanish as we approach the boundary line 
between them as we consider the more similar forms of both. Animals generally require organic food, but so also do all fungi, mushrooms, rust, smuts, mildews and moulds. Animals generally eat solid food and plants generally do not, but some plants like Venus's fly-trap and Drosera can surround and digest solid food. Plants are generally fixed to the soil where they grow, but so also are many kinds of hydroids, corals, sea-fans, etc., and many kinds of plants move freely at some stages of their lives, as freely as animals do. It has always been true that naturalists could not agree as to whether certain forms are animals or plants. From time to time it is agreed that certain forms hitherto regarded as belonging to one kingdom, shall be set down as certainly belonging to the other. It has often been proposed to have three kindgoms, a plant kingdom, an animal kingdom and a plant-animal kingdom; and this would long ago have been done but for the fact that it would simply have multiplied the difficulty by two; it is now impossible to determine in all cases whether a given form should be called animal or plant; if three kingdoms were recoginzed it would be impossible to distinguish animals from plantanimals and plants from plant-animals. The impossibility of separating plants and animals except by arbitrary bounds, is one reason why modern science recognizes the term Biology, the science of life.

That the animal moves is probably an adaptation to its food supply, which is, in general, solids that it must go to get.

That the plant is fixed is likewise perhaps an adaptation to the fact that its food-stuffs are liquids and gases that can and do come to it. 


\section{LESSON XCV.}

\section{Protoplasm.}

\section{The Respiration of Plants.}

It was thought for a long time that plants consume carbon dioxid in respiration and give off oxygen and that animals consume oxygen and give off carbon dioxid. This is wrong, but it is so nearly like something that is right that it is hard to correct. Plants retain the carbon of carbon dioxid and give off oxygen during the day time, but they do not consume the carbon in breathing; they make it into food on which both they and animals can live; they use it in their work of photosynthesis. The part of the plant, however, which lives must consume oxygen. During the night plants give off carbon dioxid as a result of their breathing just as animals do. During the daytime their breathing is disguised by the larger work they are carrying forward; during the day they give off carbon dioxid in respiration, but consume in photosynthesis more than they give off: Plants that are not green and cannot therefore do photosynthesis give off carbon dioxid all day long just as animals do.

Exercise I. Make lime-water by soaking a pint of lime in two quarts of rain-water a few days. Pour off the clear lime-water and keep it in a tightly corked bottle. Pour a little of this water into a test tube or homeopathic vial, breathe on it and shake it up and it will turn milky on account of the carbon dioxid in your breath. Now soak two ounces of peas by measure, in warm water over night and place them for twelve hours in a six-ounce bottle, well corked. Decant the air from this bottle into a little limewater as before and shake it; it becomes milky. The sprouting peas give off carbon dioxid also. 
Exercise II. To show that chlorophylless plants give off carbon dioxid, put a growing mushroom in a fruit can, seal it and after a day try the air of the can with lime-water.

Exercise III. Put a healthly potted plant in a fruit can, close the can tightly and set it where it is perfectly dark for twelves hours and test the air in it for carbon dioxid. If it is not put in the dark, carbon assimilation will disguise respiration; but the respiration will not be any the less real because it is disguised.

\section{LESSON XCVI.}

\section{Protoplasm.}

\section{The Cell.}

Among the great achievements of the nineteenth century is the discovery of protoplasm and the proof of its identity in animals and plants. Protoplasm has been defined as "the physical basis of life." We can, perhaps, better get at the fact if we say it is the thing that lives, the only thing. Protoplasm makes starch and fat, the cell wall in all its forms and all its varied cell contents. It is a granular, nearly transparent substance; it can surround a bit of food and digest it; it can grow and divide so that what was one individual, becomes two ; or what was one cell, becomes two, Figures 143 and 145. Two separate masses can combine so that two cells become one. Figure 140 shows two filaments of a common green pond-scum which have grown passage ways from one to the other through which the contents of two cells can unite; the process is going forward at the top of Figure 147; it is completed at the bottom of the same figure. Protoplasm is sensitive to heat and cold, to an electric current or any sort of bodily contact. It requires food and oxygen to carry on its life processes; it can work in the dark as well as in the light; indeed most of it 
is shut up in the more or less opaque walls of plant or animal cells and does its work there; it can carry on the processes of assimilation and excretion. It is contractile; it can slowly move about from place to place when free or it can move about within the cell wall that confines it. It can build cell by cell the oak or the elephant and it is its activities that enable all living things to do whatever they can do. It can surround itself with a wall of wood, of phosphate of lime as in bones, of silica. Goethe, who explained so well the transformations of the leaf, thought there must be somewhere a type plant by the modification of which all plants are made. This type plant, "Urpflanze," as he named it without seeing it, is the typical plant cell. When he sat in his gardens and talked about them but could not find them, millions of them clothed his trees from root to crown, for the green coating on bark and fences in damp countries and localities often consists almost entirely of them. Multiply them enough and modify them enough and the miracle of the vegetable world is all about us; and cells in the presence of the proper stimuli can be shown to be able to do this multiplying and modifying.

\section{LESSON XCVII. \\ How Plants Multiply.}

The Asexual Way.

Go first to the strawberry and see the runners, prostrate stems that grow out along the ground and take root at a suitable distance from the parent stem. This is one way that a plant can become two. Figure 142 shows a similar mode of multiplying in the water hyacinth, a plant found 
in abundance on the St. John's river in Florida. The petioles of the leaves swell out into large floats (a) and by their number and arrangement keep the plant upright and prevent it from sinking. The runner has sent roots down into the water six inches away from the parent plant. This plant has so spread over St. John's river as to seriously interfere with navigation and the government has made

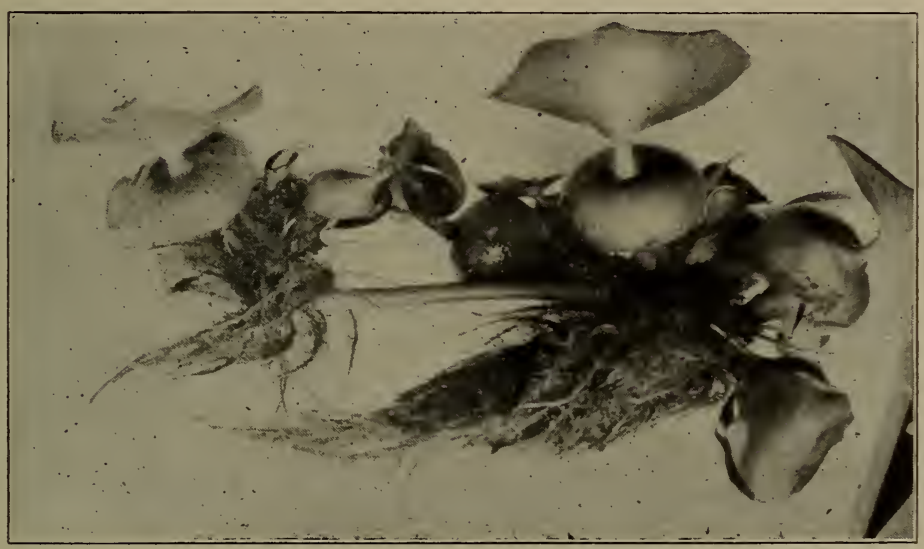

Fig. 142.

Water hyacinth. See text.

an appropriation for the year 1903 for the purpose of stamping it out.

Go next to the raspberry, or if you know it, to the walking-fern; the raspberry bends its tip over to the ground and the fern its to the rock wall on which it grows and they alike take root at a distance from the home-plant and one becomes two. Cut off a number of limbs from a willow and plant them along a stream; they will grow into trees. Are they new trees? Individuals? If they had grown on the old stem would they have been new trees? Is a tree a 
colony? Budding consists in taking uninjured buds from one tree and planting them under the bark of another tree. Grafting consists in taking little shoots from one tree and properly planting them in the limbs of another. Suppose wine-sap, bellflower and five other varities of buds are planted on the seven limbs of a seedling and grow into thrifty, fruit-bearing branches; what sort of tree is this? Is

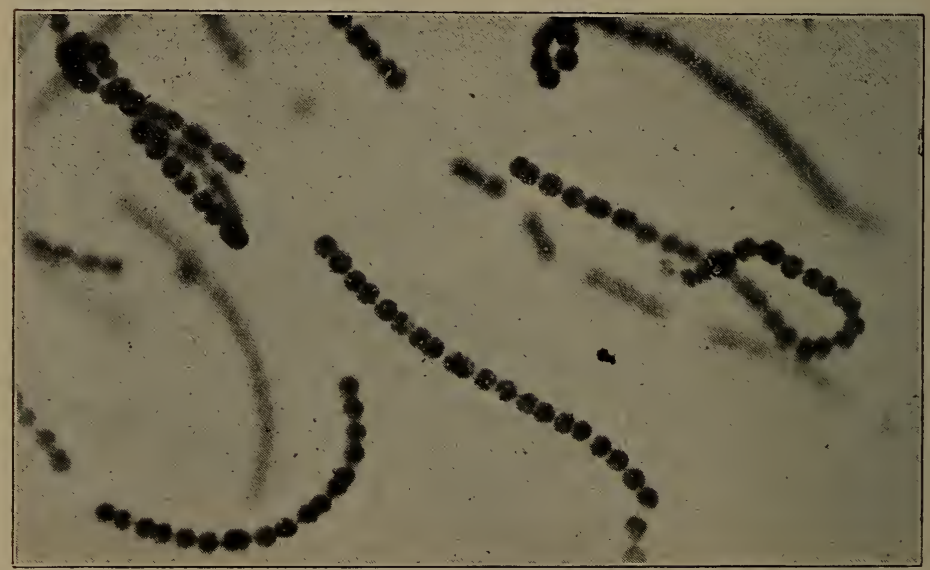

Fig. 143.

Filaments of Nostoc, a blue-green alga in process of cell division. $\mathrm{x} 400$.

it seven trees? Is every bud an individual in the colony that goes to make up a tree?

There are many one-celled plants that have only this asexual way of multiplying. Figure 143 is a blue-green alga that may be found in gutters, often along the street or damp places in greenhouses; it is called Nostoc. The cells of the filament here shown are in several stages of division. 


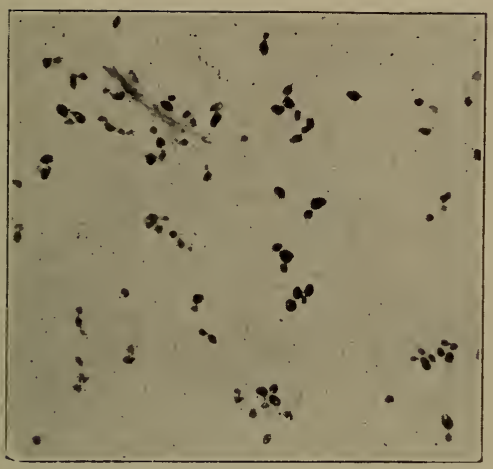

Fig. 144.

Yeast-cells in process of budding. See text. $\times 200$.
Figure 145 shows a parasite plant that is often found in sores on the body; it is often coughed up by patients suffering with sores on their lungs. Several stages of cell division can be seen.

Yeast owes its properties to a one-celled plant that lives and grows in suitable liquids. The yeast-plant has a peculiar way of dividing,

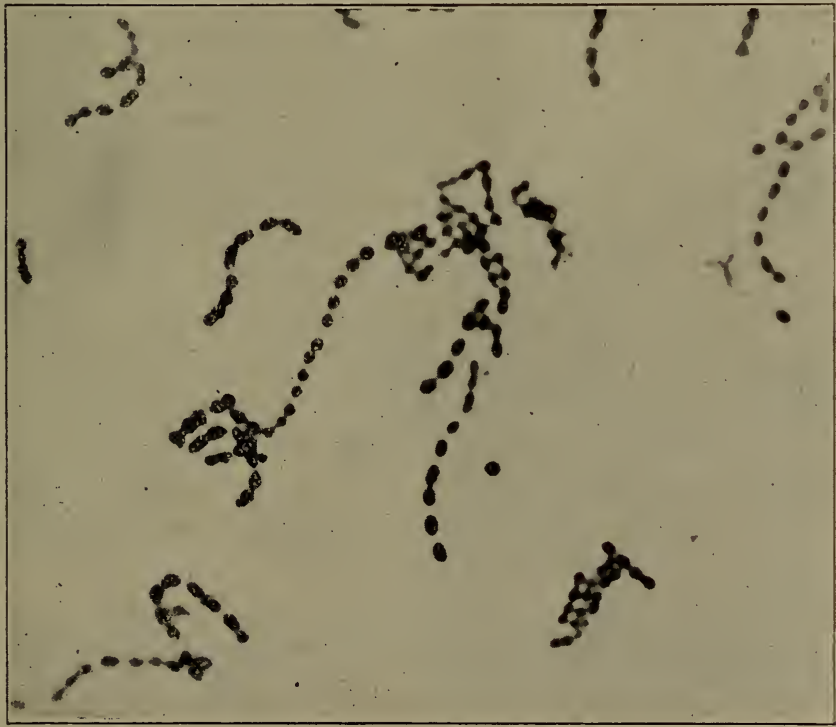

Fig. 145.

Filament3 of Streptococcus dividing. The kinship in form of Nostoc and Streptococcus is orie good reason for regarding bacteria as degenerate plants. Highly magnified. 
called budding, Figure 144; a very small bud appears on one side, which grows until it is as large as the mother-cell. It is called the daughter-cell; in actively "coming" yeast it often happens that a daughter-cell begins to bud before it separates from its mother. This is true of a grandcaughter and great granddaughter-cell also before any of them have let go, so that it is possible to get four or five generations in one picture.

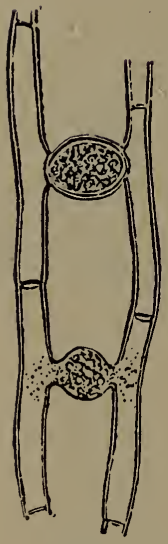

Fig. 146.

Rer,roduction by celi union on neutral
ground, no ground, no
distinction of male and female.

\section{LESSON XCVIII.}

\section{How Plants Multiply.}

\section{The Sexual Way.}

Another very different mode of reproduction is by the union of two cells one of which is known as the male cell and the other as the female. Figure 146 shows two exactly similar plant cells uniting on neutral ground. This is the simplest possible sexual multiplication. The new individual formed by their union will divide many times asexually to form new generations. In this instance it is not possible to say which is male and which is female, for both look and act exactly alike.

Figure 147 shows two cells uniting, but not on neutral territory. The cell contents of all cells in the left filament pass entirely through the funnel tube to the right filament. Both cells help to make the connecting tuke; they look alike, but do not act quite alike; there is physiological, but not ana- 
tomical, distinction of sex; the left filament is the male filament. The egg-shaped bodies in the female cells are

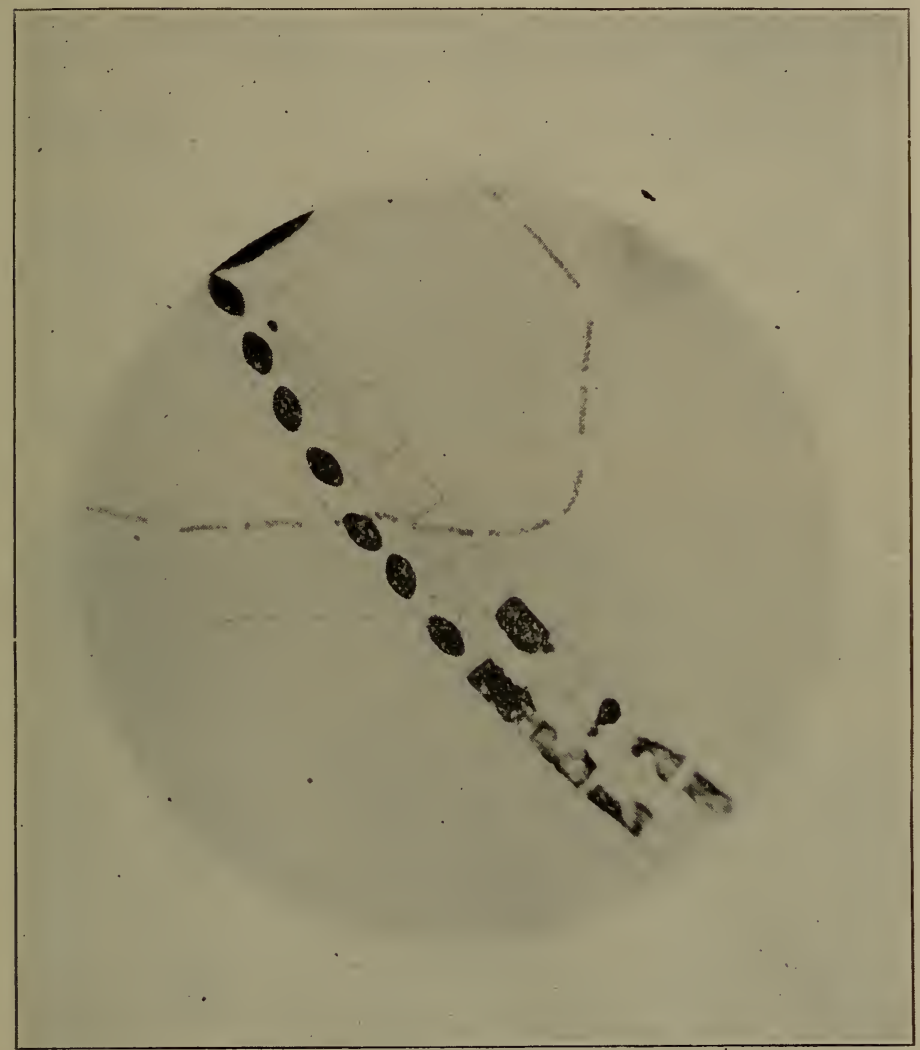

Fig. 147.

Spirogyra. Reproduction by cell union in the home of the femaie cell; physiological distinction of sex, not anatomical; the filaments look alike. $\times 200$.

new one-celled plants; the parent cell walls will decay and after a rest these will all grow by division into new filaments of pond-s?um. 


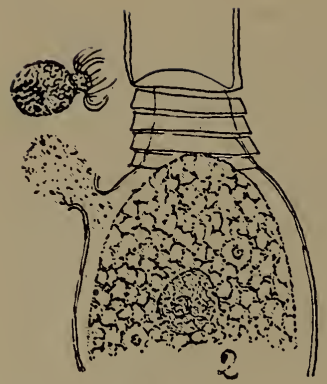

Fig. 148.

Oedogonium, a common green alga attached to sticks and stones. 1 , the small motile male cell goes to the large female cell. 2. Anatomical and physiologica distinction of sex. Atter Oltmans.

activity the male being the more active; in protective
Nature Study.

Figure 148 shows male and female organs of a plant in which there is anatomical, as well as physiological, distinction of sex; here the female cell not only stays at home and awaits the coming of the male, but it is larger, better fed and better housed.

Any number of illustrations could be added showing progress in dissimilarity between the male and female cells. This difference is in size, the male being the smaller; in

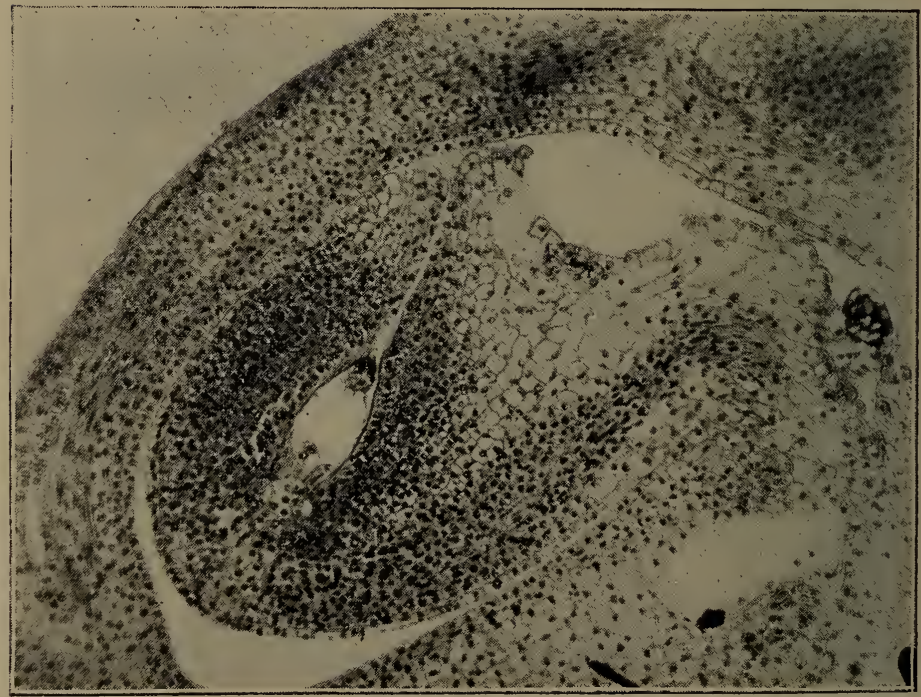

Fig. 149.

Section through the well-protected, well-fed home of a female cell of Erigenia. The section is through the micropyle through which the male nucleus enters. Slide prepared by Mr. Charles H. Frazee. x 100 . 


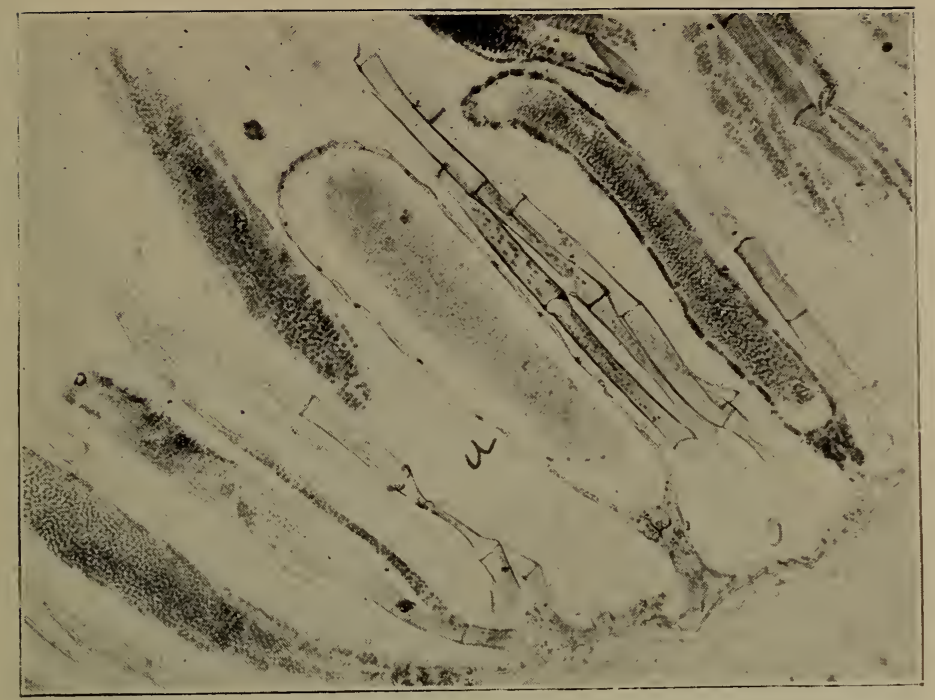

Fig. 150.

Cross-section of the summit of a male moss plant. a, ail antheridium containing perm-cells. x 200 .

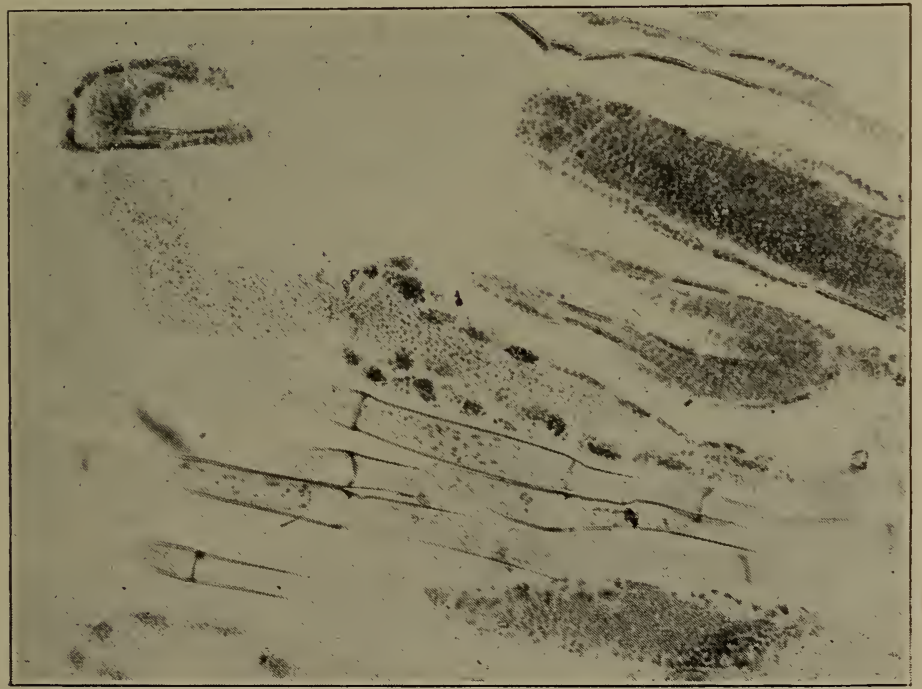

Fig. 151.

The same as Figure 150, with antheridium discharging sperm-cells. $\times 20 \mathrm{c}$. 
coverings and mode of nutrition, the female being the better cared for and better fed. Figure 149 shows the safe and well lardered house of the female cell of the harbinger-of-

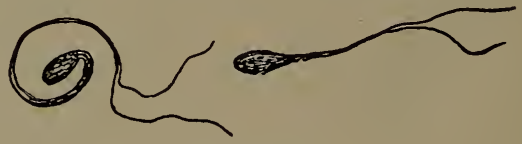

Fig. 152.

Two sperm-cells of moss very highly magni.ied. After Atkinson.

spring, Erigenia bulbosa. Figure 150 shows the summit of a male moss stem. (a) is a longitudinal section of an antheridium containing sperms. Figure 151 shows an antheridium bursting and dis-

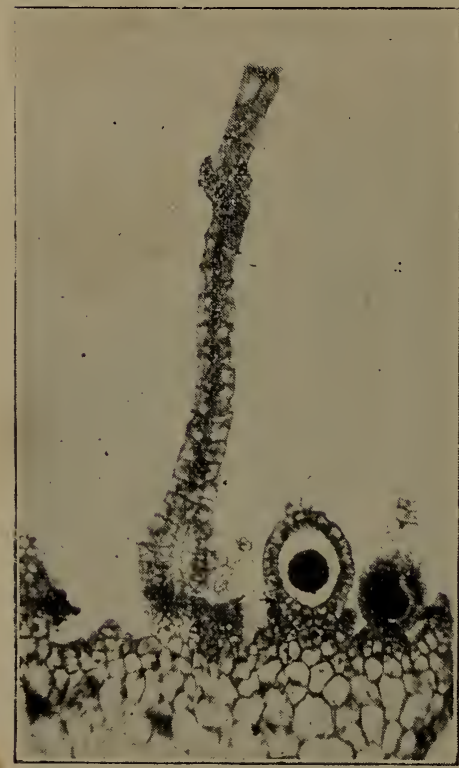

Fig. 153.

Archegonia of a liverwort, Marchantia; 1 , an almost longitudinal section through the entrance: 2 , passes through an eggcell. These are ver, similar to the same organs in moss. $\times 200$. charging the sperms. A simple sperm, when mature, resembles Figure 152. This swims by means of its cilia into the archegonium of the female moss head which closely resembles Figure 153 . It reaches the egg-cell at the bottom of the archegonium, and fertilizes it. It will be seen by these figures that among mosses the differences between the egg-cell and the sperm-cell are very great.

Figure 154 shows at (a) the fertilized egg-cell of the harbinger-of-spring.

A11 higher plants, mosses, ferns and flowering plants produce in one way or another and at one time or another in their life history, 
such a fertilized egg-cell, and from this cell new plants grow.

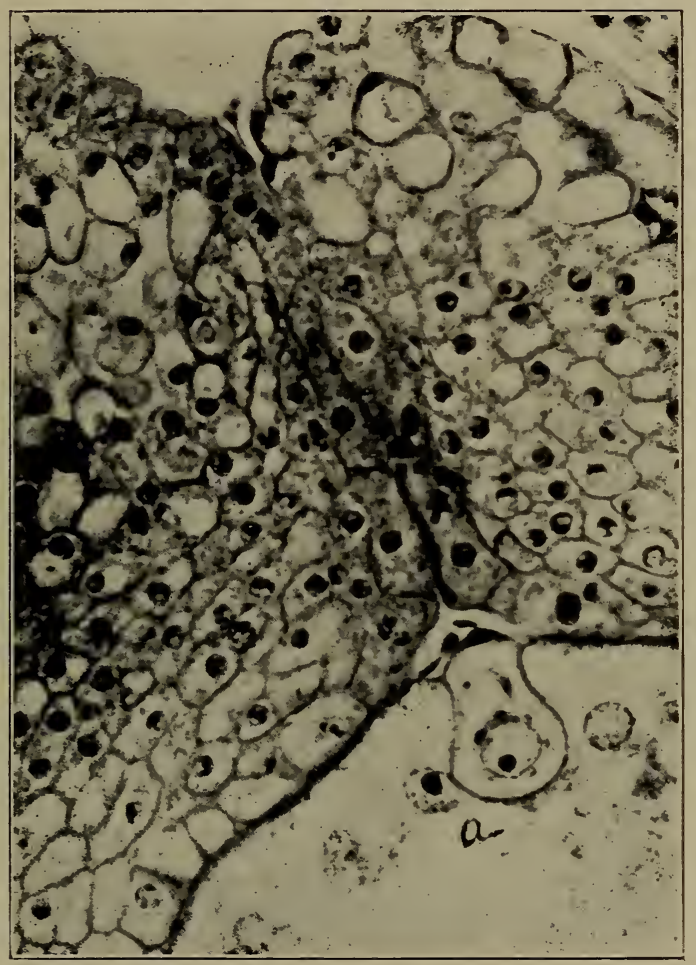

Fig. 154.

A section of a young plant of Erigenia bulbosa during the resting stage after the egg-cell had been fertilized. Slide prepared hy Mr. Charles Frazee. x 750 .

Figure 155 shows a young embryo of a smartweed; the fertilized egg-cell has divided twice so that it now consists of four cells. Figure 156 shows a stage considerably more advanced. It is thus by cell division, unequal growth, in different parts, unequal growth in the cells themselves, and 
the development of walls of varying thickness and quality, that the plant with its organs and tissues is matured.

It is worthy of note that the pistil which houses the female cell, the macrospore, grows at the center of the receptacle, in the direct line of the food supply; the stamens always grow to one side and are accordingly, never so well-fed; they

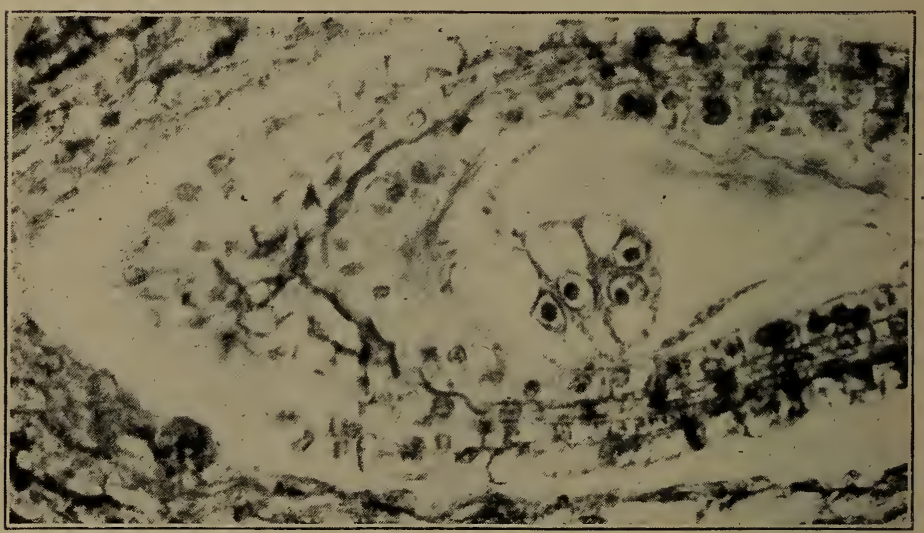

Fig. 155.

A young smartweed after the fertilized cell had divided and the two resulting cells had again divided. Slide prepared by Miss Ruth Trueblood. x 750 .

often grow on the sepals or petals or even on the ovary itself, and must be content not only with a side flow of sap, but they must share this side flow.

A fine study for any one with a microscope would be to determine the relative amount of conducting tissue that leads to a stamen and a pistil. To get the real ratio, these amounts should then be divided respectively by the number of pollen-grains the stamens bear and the number of seeds the pistil can bear. 


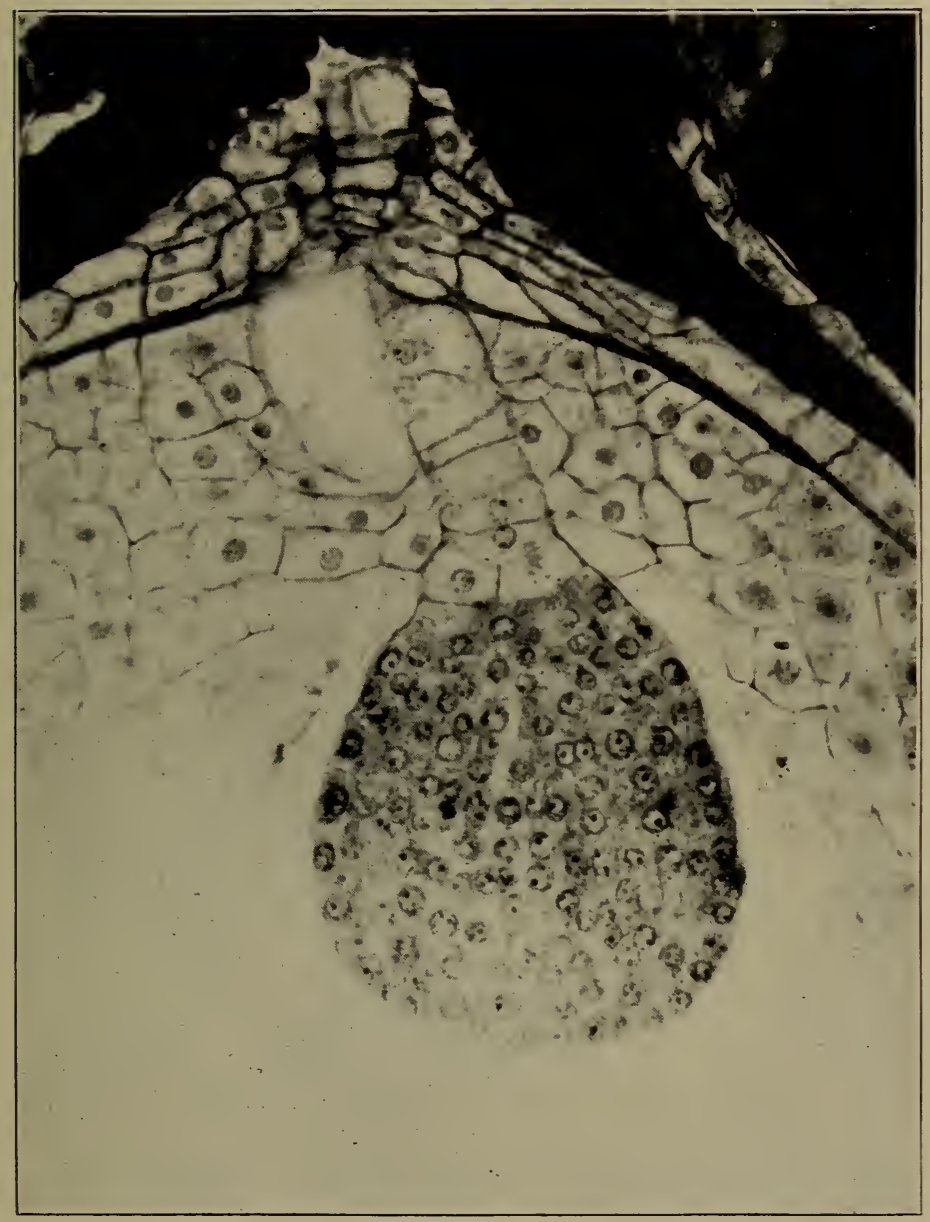

Fig. 156.

Many-celled stage of a young plant of twinleaf. Slide prepared by Mr. Charles Frazee. $\times 750$. 


\section{LESSON XCIX. \\ Growth from the Cell to the Tree.}

Cells have been shown in process of division. Sometimes they divide in one plane only and we have then a filament like Figure 143. Sometimes they divide in two planes only and we have flat plants of varying length and width but only one cell thick. Some moss leaves, except in the region of the veins are such structures. Sometimes cells divide in three planes and then we have figures of varying length, breadth and thickness like most of the plants we know. The almost infinite variety of shapes in plants arises from two causes. First, the cells divide in their different planes a different number of times, many divisions in one plane, giving length, fewer in another giving breadth, and fewer still in the third, giving thickness. Second, the cells themselves have three dimensions. They are solid bodies and they may grow to have very varying dimensions. The typical plant cell is globular, all its dimensions are the same. Plant cells vary in their shapes from this typical form so much that their shapes could not have been conceived of or believed to be if they had not been seen. The various accompanying microscopic figures show other cell shapes.

\section{LESSON C.}

\section{Cell Duties in a Many-Celled Plant.}

In a one-celled plant its life processes are all carried forward by the one cell. It must breathe; it must assimilate; it must construct a wall if it has one; it must store up food; it must contract if it is to have voluntary motion; it must reproduce. As soon as cell union comes, with a vital union 
between two or more cells, these duties can be divided out among many or fewer different cells; a tree, for example, has protective tissue, the bark, some cells of which do nothing else; it has conductive tissue that distributes sap to all parts. It has supporting tissues that discharge no other duties than that of holding the vital parts in position. It has secreting cells such as produce the milk of the mulberry, the resin of the pine, the nectar of the flower, etc. It has storage cells for starch, fats, crystals, etc. It has assimilative tissues and reproductive and many other sorts. This division of duties can be but slight in one-celled creatures. It can only be between different parts of the same cell which is generally too small to be seen by the naked eye. Cell union has its advantages and disadvantages. In Nostoc and other similar filaments each cell is independent except for purposes of defense and buoyancy. It is a sort of defensive alliance that leaves every member of the community free to manage its own internal affairs. The community life in Spirogyra has for its advantage the extra protection and support of the common wall. The disadvantage is that individuals are subject to the accidents of the colony. If we could study all plants gradatim from the simple onecelled Protococcus to the oak, we should find very gradual steps in the formation of what may very fairly be called the combined trusts that go to make the oak. The root trust gathers the food containing moisture from the soil and hands it on; it also holds the oak in place and lends its reservoirs as storehouses. The plant has so completely given over these duties to the root that it is dependent on it for at least two of them. The chlorophyll is a trust for storing the energy of sunlight, so complete that no other part of the plant can take its place even partially or temporarily. The great advantage of these combinations is without question; because all the plants which are large enough to be seen by the naked eye have adopted them, 
and the higher the plant in the life scale the more complete, numerous, and complex are these combinations. Plant organization has been long ages in perfecting the division of labor and the co-ordination of its tissues and organs. Society's organization may one day be equally just and perfect.

\section{LESSON CI.}

Young Plants.

Every one has noticed the difference between the green gosling and the white gander, which it becomes. A chick does not much resemble a chicken. There is a difference of like meaning and importance between young and old plants.

Exercise I: Plant cucumber, squash, pumpkin, and several kinds of muskmelon and watermelon seeds. As soon as they come up, if you see any remains of the seeds, remove them and try to tell by the young plants what each one is. Try when they have only two leaves; try again when they bear four leaves. Watch them as they grow. Visit patches of all these things growing in the field and see if you can distinguish them. You will learn by this exercise that young plants resemble each other much more than old ones.

Exercise II: Gather mulberry leaves from a large tree, but not on vigorous young shoots. Gather other leaves from young trees. The leaves on young trees are lobed; on old trees they are not.

Exercise III: Learn to tell several varieties of oak by the leaves. Try now to determine these several varieties when they are not more than a year or two old, and it will be clear that the young does not resemble the old and that the young of different species closely resemble each other.

Exercise IV: Take the most irregular flower you can find, a larkspur for instance, or locust, or bean blossom. 
Learn the shapes of all the petals of the adult flower. Now examine the petals in the bud. The lesson is the same, young petals resemble each other.

Exercise V: Notice the branching of a soft maple, called also a silver maple; its branching is deliquescent like that of the elm. Notice the branching of the sugar-maple; it is excurrent like that of the fir. Now find a young soft maple and you will find that its branching is excurrent, like the sugar-maple's. You will learn from this lesson that the young of one species sometimes resembles in one or more particulars the adult of another species. These are useful lessons in the science of embryology. It has been found out as a principle that the growing young that resemble each other longest are the nearest akin. Try your watermelon, two varieties of muskmelon and cucumber seeds again and see how old they are when you can easily distinguish the watermelon from the rest. How old are they when you can distinguish the cucumber? How old when you can distinguish the two varieties of muskmelon?

It is more than suspected when the young of any dominant species resembles the adult of another species that the first species is higher in the life scale; young frogs, tadpoles, resemble fish, which are lower in the life scale; young butterflies, caterpillars, resemble worms, which are lower. At any rate it will be valuable to observe carefully the plants you study at all available ages. Do all the "baby bean" work over again from these points of view. 
"Of what use are these prickly hairs that garnish the stem?"

The next day she showed them to him covered with a slight hoar frost which, thanks to them, kept at a distance, had not chilled her tender skin.

"Of what use in the fine days will be your warm coat wadded with down?"

The fine days came; she cast off her winter cloak and her new branches sprang forth free from this silken envelope, henceforward useless.

"But if the storm rages the wind will bruise thee."

The wind blew and the young plant, too feeble yet to dare to fight, bent to the earth and was defended in yielding.

Sointine in Picciola. 


\section{PART II.}

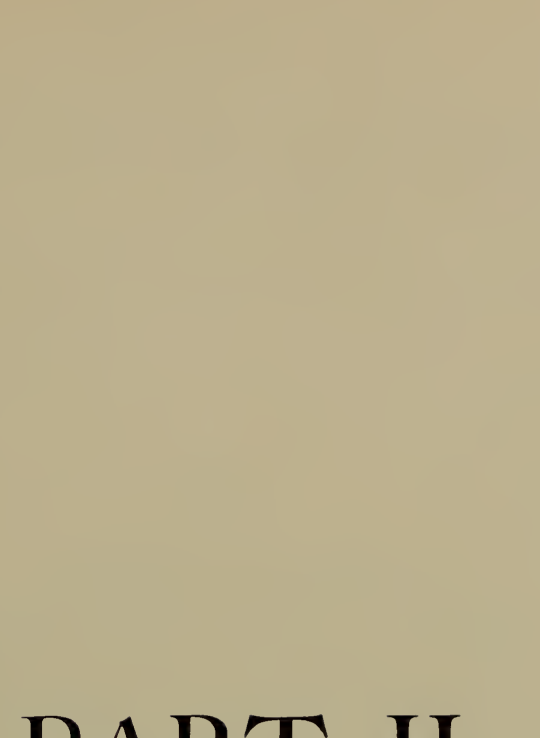

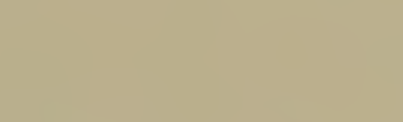

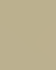

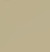

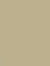

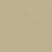

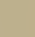

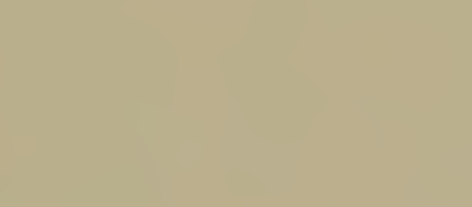




\section{CONTENTS OF PART II.}

Introductory. How to Study a Flower............ Page

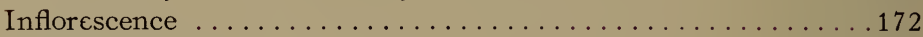

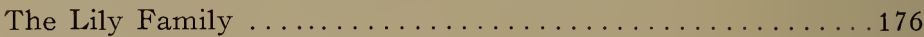

The Rose Family ............................. . 180

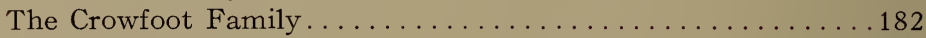

The Magnolia Family.......................... 183

The Barberry Family.......................... 183

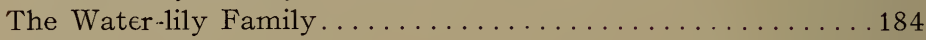

The Poppy Family ........................... 184

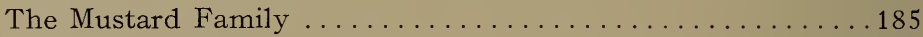

The Violet Family ............................ 186

The Pink Family ............................ 187

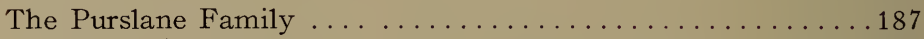

The Mallow Family .......................... 188

The Geranium Family.............................. 189

The Pulse Family ................................ 189

The Teasel Family................................ 190

The Thistle Family .......................... 191

The Nightshade Family. . . . . . . . . . . . . . . . . . 192

The Sage Family ............................. 193

The Pokeweed Family......................... 194

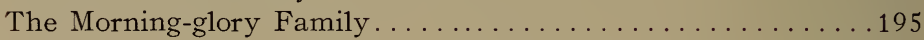

The Nettle Family . . . . . . . . . . . . . . . . . . . . . 197

The Sycamore Family . . . . . . . . . . . . . . . . . . 198

The Walnut Family.............................. 198

The Oak Family............................... 200

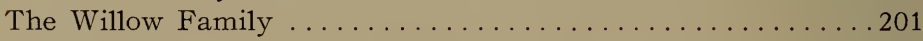

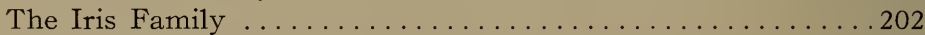

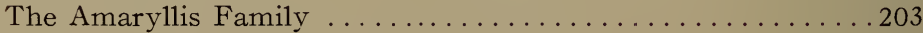

The Grass Family.............................. 203

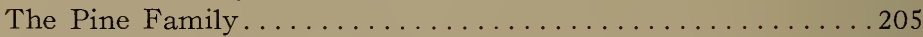

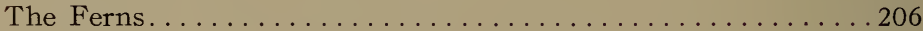

The Mosses...............................207

A List of Twenty-eight Other Families with One or More

Common Plants that Belong to Them..............208 


\section{LESSON CII.}

Introductory. How to Study a Flower.

Begin with a lily or a simple wild flower, as twinleaf, mayapple or spring beauty; a lens like Figure 157, which will cost fifty cents, or a simple dissecting microscope like Figure 158, which may be had of the Bausch and Lomb Optical Co., Rochester, New York, for $\$ 2.50$, and a pair of dissecting needles and a sharp knife will greatly help, and

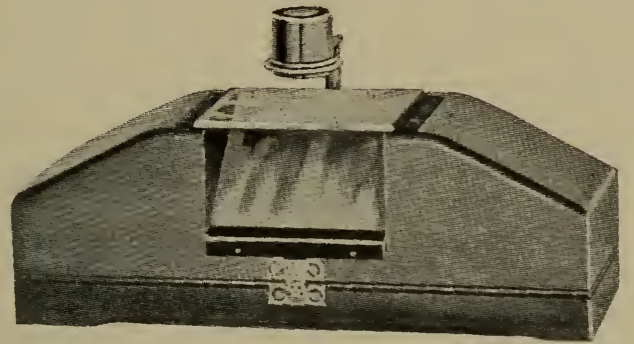

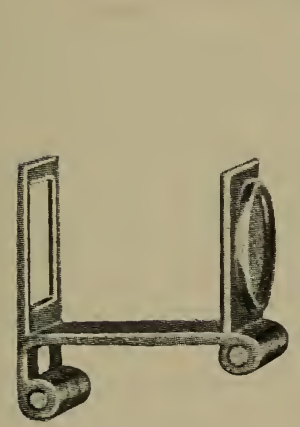

Fig 157.

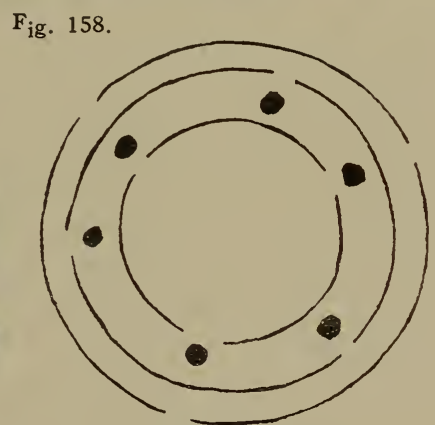

Fig. 158 1-2.

for many of the smaller flowers these things will be necessary. Don't hurry to cut the flower up; pull its sepals down without injuring them and see how many there are of them, whether they are free from the corolla and separate from each other or not, and make notes of every fact 
you are able to observe about them. It will richly pay if you will draw a sepal as accurately as you can. Next study the petals the same way and draw one if they are alike; if not draw one of each kind. Next study the stamens the same way; be sure as to whether these are alternate with the petals or sepals or both if there are twice as many; unless you are sure there are twenty or more, count them carefully. Do they grow on the calyx or corolla or pistil, or receptacle? Draw one. Next study the carpels. How many are there? Distinguish ovary, style, if any, and stigma. How many are there of each? Cut the ovary across and count the cells and the seeds in the cell and learn if you can where the seeds are attached to the ovary. Note their color, size, shape and number in a cell. Write out the number of sepals, petals, stamens and carpels thus, $3-3-6-3$ for the lily. Cut across an entire flower and make a ground plan of it thus, Fig. $158 \mathrm{1} / 2$ for the lily. What sort of stem leaves has the plant? What sort of root-leaves, if any? Draw one of every kind and press and preserve for study and comparison one of each kind. What peculiarity of color, odor, hardness, smoothness, etc., has any part of the plant? For example: The violet has a spurred petal; it has two petals hairy within; spring-beauty has a long, narrow pair of thick leaves; the corolla of narcissus has a crown, etc., etc. Compare every flower studied, with everyone previously studied. Do not leave off the study as soon as you have finished this inventory and found out its name. Compare other and younger plants of the same kind that have not yet bloomed; compare older ones or watch a growing one till it becomes old; gather the seeds from it at last and plant them and raise others. It is only as the years go on that we can become really acquainted with plants. When we have done all that we can by the methods of study here pointed out, there is yet the great subject of the minute anatomy of plants, and the physiology, 
each of which has its special methods and instruments for study that we cannot acquire away from a good laboratory. The distribution of plants is a matter of great importance, which can be begun in any locality. All these studies, if pursued with real plants, are interesting and instructive all along. Those who know most about plants, best know also that they can never know all about them. They do not, however, wish there was less to be known.

In the lessons which follow, some of the characteristics of a few common and well known plants will be considered with reference to their relationships. Gray's Manual describes one hundred and twenty-nine orders of flowering plants. These are also called families, each being named after some characteristic plant it contains; as, for instance, Plantaginaceae or plantain family. Plants should sometimes be studied with the name of the family to which they belong well in mind. A family can only be studied through the plants which it includes. It does little or no good to memorize the characteristics of a plant group in a book. These must grow in one's mind as he studies the plants of the group in connection with those of other groups. Nothing is claimed for these lessons unless they are studied in the presence of the plants themselves. If they are thus faithfully studied they cannot be otherwise than helpful. As a preliminary lesson it is necessary for us to consider some of the simpler forms of inflorescence.

\section{LESSON CIII.}

The Arrangement of Flowers on the Stem. Inflorescence. How Flower Clusters are Related.

When flowers or fruit are arranged on the stem as we see the wild cherry we call the cluster a raceme. Currents are so arranged. Tongue-grass has the same kind of inflores- 
cence; so have the flowers and fruit of pokeberry; so has shepherd's-purse. This arrangement is shown in Figure 159. It will be as good nature study work as you can do to make a list of all the plants that have their flowers arranged this way. The raceme has all its flowers on

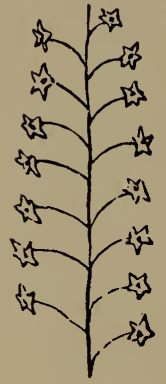

Fig. 159. Fig. 160

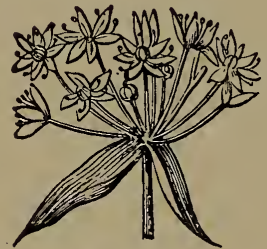

Fig. 162.

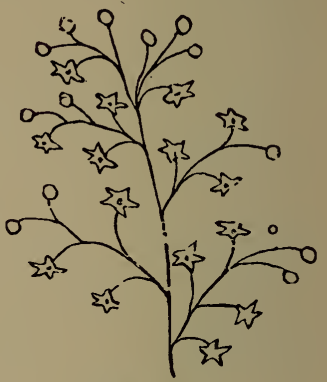

Fig. 164.

separate pedicels of the same length which grow out at different places along the flower stalk. When the springbeauties and the lilies-of-the-valley come again, see if they have this arrangement.

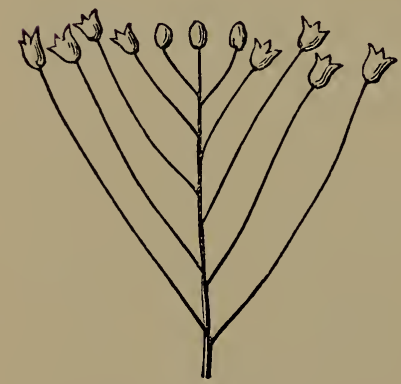

Fig. 161.

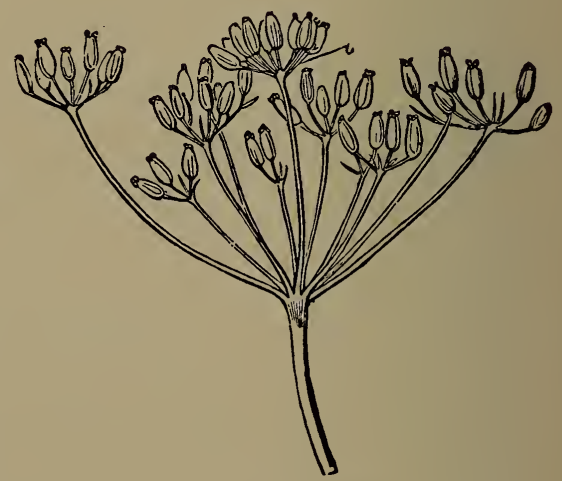

Fig. 163

Another common form of inflorescence is called the spike. It is shown in Figure 160. Look at the figures of the raceme and spike and see if you can tell how they are related to 
each other. The raceme becomes a spike when its flowers become sessile.

Figure 161 is a corymb; the raceme becomes a corymb when its lower pedicels become lengthened so as to bring all the flowers to about the same level. Try without reading further to look at Figures 159 and 162, and tell how the raceme is related to the umbel. A raceme becomes an umbel when its pedicels all grow out from the same place. There are many plants whose flowers bloom in umbels; the parsnip is one, Queen Anne's lace is another, pepper-and-salt, our pretty little harbinger-of-spring, is another. All these and many more belong to a considerable order of plants called the Umbelliferae. Many of the Umbelliferae bear compound umbels like Figure 163. A raceme becomes a panicle, Figure 164, when its pedicels branch so that each forms a small raceme. The flowers of oats form a panicle. When a panicle thickens by becoming much branched we call it a thyrse. The lilac and horse-chestnut are good examples.

Many flowers grow in heads, Figure

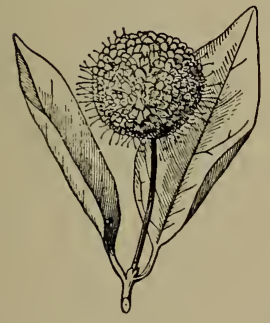

Fig. 165. 165. All the large order called compositae which contains the asters, golden-rods, dandelions, Spanish needles and many others grow so. The teasel sycamore and clover are other examples. See if you can tell from Figures 162 and 165 how the umbel might become a head. If its pedicels shortened till all its flowers became sessile it would form a head. What is the relationship between the raceme and head?

All these forms of inflorescence may be naked, that is, they may have no bracts in among the flowers. This is true of the shepherd's-purse and many other cruciferous flowers. If a spike has bracts in among its crowded flowers 
and if it hangs down,- -is pendulous,- - we call it an ament or catkin. The staminate flowers of many of our forest trees are in aments.

It is not the purpose of this lesson to multiply definitions, but to show kinship of flower clusters and the lesson is not learned until the student can look at the pictures and tell at once how all are related to the raceme and to each other; he must also be able to go to his flowers and pick out the several kinds. He will not have been long at this exercise before he will learn that the several forms shade into each other. Gradually the lower pedicels of the raceme lengthen until at last a corymb is the result; but no one can tell where one leaves off and the other begins. He will find in the lilac, the asters, the goldenrods and many other flowers, these forms mixed in every way. Nature does not always present the sharp lines our figures show so clearly. Everywhere her steps are so gradual that all careful students now have to think that her sharper distinctions have gradually grown up and presented us at last with all her varied forms. Try to interpret this:

A raceme - pedicels becomes a spike.

A raceme - rachis becomes an umbel.

A raceme + longer lower petioles becomes a corymb.

A raceme + branched pedicels become a panicle.

A raceme - rachis and pedicels become a head.

Flowers are, as every one knows, often solitary, that is just one growing at the end of a stem; this arrests the growth of the stem and is one form of determinate inflorescence. When a stem begins to bloom at the botton and continues to grow at the top, as the shepherd's-purse or plantain, it may bloom on as long as the season lasts; it is indeterminate.

If, however, a stem begins to bloom at the top and blooms downward, or if a flower cluster begins to bloom at 
the center and blooms outward, it cannot bloom indefinitely; its blooming in such cases is called determinate.

\section{LESSON CIV.}

\section{The Lily Family.}

The Liliaceae.

The Liliaceae. The Kinship of Plants: What it Means to Trace Kinship.

Every one knows the lily; it is famous in all countries and all literatures. The trillium, smilax, onion, star-ofBethlehem, grape-hyacinth, lily-of-the-valley, Solomon'sseal, asparagus, dog-tooth violet, and other less common plants belong to the lily family. Instead of saying calyx and corolla, we give one name, perianth, to both in the lily, because both are generally colored alike. The perianth consists of six floral leaves. There are generally six stamens and a three-celled ovary. Many of the liliaceae grow from some sort of underground fleshy part like the rootstock of Solomon's-seal, see Fig. 55, the bulb of the lily, Figure 71 , etc. This enables them to bloom early, compare Lesson LXXXII. It is also true that some of the lilies have the blossom already formed underground, so that when the warm days of spring come there is nothing to do but push them above ground and unfold them.

As the season advances, mark the spot where trilliums and dog-tooth violets grow and dig them up in September and every month thereafter to see the slowly forming, flower.

Series I. Seed-Bearing Plants.

Two series of plants are recognized; those that bear seed and those that do not. The lily bears seeds and so belongs 
to the first series, the Spermatophytes or seed-bearing plants.

\section{Classes.}

There are two classes of seed-bearing plants; those with one seed leaf called monocotyledons, and those with two called dicotyledons. The lilies belong to the monocotyledons, that is, they have but one seed-leaf. Every one should examine germinating corn and beans at several different stages to see the difference between plants with one and two seed-leaves. The bean is a dicotyledon. The lilies have stems like the smilax, palm and corn, see Lesson LXXVI. The leaves are generally parallel veined; compare the venation of the lily or dog-tooth violet with the maple, (palmately veined) and the beech (pinnately veined). It is important to notice also that the parts of the flower are generally in threes, as in the case of the lily, three sepals, three petals, six (two times three) stamens and a three-celled ovary.

\section{Families.}

These monocotyledonous qualities, the lily family shares with other monocotyledonous families, as the iris family, the amarylis family, the grass family and several others. Three lessons following this, Lessons CXXIX, CXXX and CXXXI will be about the blue flag, the amaryllis and the oats; and every one should note especially how they differ from the lily; this will be a beginning of acquaintanceship with family differences. The various families are made up of more or fewer groups each of which is called a genus (plural genera). The members of each genus are more nearly related than they are to the members of other genera; among the liliaceae the Solomon's-seal, the dog-tooth violet, the lily and the trillium represent four genera. These should be carefully compared with each other to get a 
notion of differences that are generic. Notice in Solomon'sseal that the bracts are not green but membranaceous, scarious we call them; that the stamens grow on the perianth, perigynous, that the perianth is united, cylindrical and six-notched at the summit, that the anthers open within, (introrse), and that none of these things are true of the others; they have no bracts, their stamens are hypogynous, $i$. e., they grow on the receptacle or at the base of the distinct segments of the perianth; that they open on the back or at the side or, in the case of the trillium, sometimes within.

\section{Genera.}

The Erythronium (dog-tooth violet) is distinguished in this group by a scape which comes from a solid bulb and bears generally a single flower and a pair of smooth shining leaves that sheathe the scape at the base.

The lily is borne on a leafy stem from a scaly bulb. Its perianth-parts are colored alike and wither.

The trillium bears three leaves in a whorl, its sepals are leaf-like and persistent; it has a solitary flower and its leaf-bearing stem comes from a tuber-like rootstock.

Compare the pistils of these four and any other liliaceous genera; compare their seeds. When we have come to look unweariedly and exhaustively at things, comparing one with another, we shall have one necessary accomplishment of the naturalist.

\section{Species.}

There are two common dog-tooth riolets, the yellow and the white. These are different species. Find them and make out all their differences. Which has leaves with few or no spots? Which has spreading stigmas? Which has teeth on the inner division of its perianth? These differences of color and slight differences of form when they reappear with considerable certainty in the descendents of 
each, constitute specie-distinctions. You will often have trouble in distinguishing species. Naturalists, however learned they may be, have this trouble. This is because species vary. If you seek seriously to know all the plants of your neighborhood by name you will quickly learn that species change. No one can define species with a definition that will always hold. Man is a species; one does not have to look long at a negro, an Indian, a Chinaman, and a white man to learn that species greatly vary. We call the different sorts varieties when they breed true, have a habitat of their own and between their home and the home of the species all the differences fade gradually out. There are many varieties of Indian corn known to all of us.

If now we label the yellow dog-tooth violet, it is, first: Erythronium americanum, this is its specific name. All the millions of individuals, its uncles, cousins and grandfathers, resemble it enough to be mistaken for it. They are its near kin. Its generic name is Erythronium. Its relatives of this degree are more numerous but less akin, have fewer points in common with it. Its order name is Liliaceae and of relatives removed so far there is an almost uncountable number of individuals but they have yet fewer points in common.

It belongs to the monocotyledons and at this remove, its relations again vastly increase, but they are less akin, the grasses are now among them.

The monocotyledons and the dicotyledons belong to the Spermatophytes. At this remove, all plants that bear seeds are akin to the dog-tooth violet. Finally it is a plant instead of an animal and this remove makes the number of its relations unthinkably great. It is alive instead of dead and this makes the animals more like it than minerals are. To classify is to trace out kinship.

Dog-tooth violet is a living thing, a plant, a spermatophyte, a monocotyledon, a liliaceous plant, an erithronium, 
an Erithronium americanum. If we know the meaning of these words they will all give us information about our plant.

"It is the naturalist rather than nature that draws hard and fast lines everywhere and marks out abrupt boundaries where she shades off with gradations.

One of the lessons which the philosophical naturalist learns or has to learn is that differences, the most wide and real, in the main, and the most essential, may nevertheless, be here and there bridged over by gradations."

Asa Gray in Darwiniana, page 289.

\section{LESSON CV.}

\section{The Rose Family.}

\section{The Rosaceae.}

The apple, peach, pear, plum, cherry, wild cherry, spiraea, Waldsteinia, strawberry, mountain ash, hawthorn, raspberry and many other common plants as well as the rose belong to this family. Find out the characteristics of this order by examining the flowers instead of reading from a book. Get a wild rose for your first lesson. How many petals has it? Are they all separate? Do they fall off or pull off in one piece or more than one? Do all the sepals grow together at the base? Are the stamens

Note-The order of these lessons has been determined by the sequence of Plant Families in Gray's Manual, except in the case of the Lily Family and the Rose Family. These I have placed first because they are well known, comparatively simple and can be had at almost any time of year either cultivated or wild.

In teaching, the order of these lessons is of so little importance that it should be determined solely by the ease of obtaining abundance of fresh material for study. 
few or many? Do the stamens and petals grow on the receptacle with the sepals and pistils or do they grow on the rim of the calyx tube? Are the pistils few or many? If you will answer these questions you will know some marked characteristics of the rose, the genus Rosa which gives its name to the family. If you memorize the following you will know words only.

The rosacae are plants with regular flowers; they have five petals and many stamens, all of which grow on the calyx tube: that is, they are perigynous. The pistils are one to many and except in apples, hawthorns and mountain ashes they are distinct. It is important in the study of this family that the student become acquainted with the receptacle,- the end of the stem on which the flower is borne. In spiraea, this is cup shaped, in the strawberry it is conical, fleshy and the seeds are imbedded in it; in the rose it is urn shaped; open the urn and find the carpels. In the apple the parts are differently arranged according to the age of the blossom or growing young fruit. The perigynous parts become epigynous (on the gynoecium or pistil instead of around it) by the growing together of the thickened calyx and carpels. In the raspberry the receptacle is conical but not fleshy; the fruit comes off and leaves it on the stem. In the blackberry it is fleshy and comes off with the fruit; is a part of it.

\section{LESSON CVI.}

\section{The Crowfoot Family.}

The Ranunculaceae.

The clematis, wind-flower, liverleaf, the meadow-rue, the rue-anemone, eighteen species of crowfoot, the marshmarigold, the columbine, yellowroot, larkspur, and other less common plants belong to this family. 
Any of these flowers will do for a study of the family. Several of them should be collected: This will be easy in the spring. The sepals, petals (if any), numerous stamens, and one to many pistils are all distinct and unconnected; This is why your systematic botany describes this family first. Nearly all of the family are herbs; the juice is colorless and generally acrid. The marsh-marigold is very common; it grows in wet meadows and marshes; often it covers several acres. Its gold on its background of green is very striking in April and May; its sepals are yellow; it has no petals. It is often cultivated as a potted plant. Its stamens are numerous and its pistils are about ten; it has large, roundish or sometimes kidney-shaped leaves.

The wind-flower, Anemone nemorosa blooms at about the same time. Hunt for it along the edge of the woods. It differs from the marsh-marigold in size, color, foliage and habitat. The sepals are white, generally tinged with purple or sometimes blue, the flower is on a long stalk remote from the involucre of compound leaves.

The liverleaf grows from a rosette of leaves on hairy stalks that lived over the winter. It has an involucre of simple leaves close to the flower. The flowers of this family are easy to study because all the whorls are separate and neither sepals, petals, stamens nor pistils are united among themselves. Many of them come early in the spring and most of them invite to study by their beauty.

There can be no pleasanter introduction to plants than through these flowers. Remember that when only one whorl of floral leaves is present we call it a calyx and its parts sepals and you cannot go astray. 


\section{LESSON CVII.}

\section{The Magnolia Family.}

\section{The Magnoliaceae.}

The Magnoliaceae are much like the Ranunculaceae in their flowers: The pistils, however, cohere and cover the receptacle. They are trees instead of herbs. We need to learn about this family because our beautiful and valuable tulip belongs here. We call it poplar, especially when we speak of poplar lumber we mean the lumber of the tulip. It is soft, light, durable, easy to work. Our fathers used to dig sugar troughs and watering troughs out of it. They split it into rails, hued it into timbers for their houses and barns and covered their buildings with shingles cut from it. Its large, bell-shaped, orange-marked corolla and its green leaves, truncated at the end, mark it very distinctly among trees. It has three reflexed sepals and six petals. Its stamens open cutward: Figure 83 shows one of its winged seeds hulled cut frcm its united carpels.

\section{LESSON CVIII.}

\section{The Barberry Family.}

The Berberidaceae.

We may acquaint ourselves with the Berberidaceae through the barberry bush (see Figure 68 for the leaves), or the twinleaf, one of our commonest spring flowers. The stamens are fewer than in Ranunculaceae, they equal the petals in number and are opposite to them. The sepals fall off as soon as the flower opens; so one often makes the mistake of calling the white petals the calyx. The anthers open by lids at the top; the pod also npens by a lid hinged 
at one side. The flower stalk is low and the flower an inch broad. The leaf is divided into half-egg-shaped leaflets.

The may-apple is an eratic member of this family, with stamens twice as many as the petals and not opening by lids at the top. It has a peltate leaf and a large fleshy berry.

\section{LESSON CIX.}

\section{The Water-lily Family.}

\section{The Nymphaeaceae.}

This family is close akin to the foregoing. Every one may have an opportunity to study it in the white waterlily which can be had in the markets where it does not grow. Consult Lessons XLV and LXXI.

Find the pistil and see that it is made up of many united carpels, that the stamens grow on it, and that the petals are in part adherent to it.

\section{LESSON CX. \\ The Poppy Family. \\ The Papaveraceae.}

We ought to know something of the Papaveraceae on account of the bloodroot. This flower is one of our early spring friends. It is solitary, white, has two sepals which fall when the fiower opens, eight to twelve petals and some twenty-four stamens. The pistil is one-celled but is made up of two carpels as we learn from the two rows of seeds on its wall. It grows from a short rootstock full of a red acrid juice. Its leaf is rounded and palmately lobed. 


\section{LESSON CXI.}

\section{The Mustard Family.}

\section{The Cruciferae.}

This family is a large one; to it belong the mustards, the cresses, the radish, cabbage, turnips, peppergrass, shepherd's-purse, sweet-alyssum, and many other plants.

It is what we call a very natural family, that is it is easily distinguished from other families by peculiarities that mark its relationships; when we distinguish plants by size, color, leaf-shape, etc., as we often can, we are guided by artificial marks as these give little hint of real relationships. An artificial key seizes on distinctions easily made out; a natural key, if one were possible, would guide us to the plant by its most significant marks of relationship; a scientific botany bases its distinctions on natural differences as much as possible; but because these are often not known, and often very difficult of observation, every key must be more or less artificial.

The Cruciferae have four petals arranged in the form of a cross: they have six stamens, four long and two short, tetradynamous, and the pod is a silique, long pod like mustard, or silicle, a short pod like that of shepherd's-purse. These pods are two-celled, separated by a thin partition. The flowers are so nearly alike that generic characters are taken from pods and seeds. An early spring flower, Dentaria laciniata, called in Gray toothwort and pepper-root, is a good plant on account of the larger flower it bears with which to begin an acquaintance with this family; the toothwort grows from a rootstock deep in the ground; it has a whorl of three much-divided leaves; the flowers are white or rose color. 


\section{LESSON CXII.}

\section{The Violet Family.}

\section{Violaceae.}

The violet needs no introduction anywhere. It comes early and stays late. Any one who will try, may acquaint himself with the parts of a flower through it as there can be no doubt about its identity.

The common blue violet, Viola cucullata, is taken for description. The sepals are five slightly united, auriculate, green and persistent. The petals are five, one of them spurred; the stamens also are five, the anthers grow slightly together over the pistil which is made up of three carpels. See the open pods at the right in Figure 53. The leaves and flower-stalks grow up directly from the underground rootstock. The species varies greatly; in color from deep violet blue to white; in surface from glabrous to villous-pubescent; in leaf-shape from roundish heart-shape to kidney-shape or crenate. See description of Figure 53 for its flowers that never open.

\section{LESSON CXIII.}

\section{The Pink Family.}

\section{The Caryophyllaceae.}

Pinks and carnations we all know and the chickweeds we all should know, they grow everywhere in damp grounds;low plants, about six inches high, with little star-shaped flowers. The sepals are four to five; the petals are four to five but so deeply two-cleft that they seem to be eight or ten. The plant can be told by its deep cleft white petals. 
The stamens are eight to ten or fewer; the styles are three rarely four or five, opposite the sepals; the seed-pod, however, is but one-celled; it contains many seeds. The leaves are opposite and on the common chickweed they have hairy petioles, on the great chickweed they are sessile.

\section{LESSON CXIV.}

\section{The Purslane Family.}

\section{The Portulacaceae.}

Two of our commonest plants belong to this family, purslane and the spring-beauty. We can well learn from them what an unsymmetrical flower is. Symmetry refers to number. The spring-beauty has two green sepals and generally five petals with a stamen on each petal claw. The style is three-cleft so we conclude the carpels are three. The formula, then is, for the flower, 2, 5, 5, 3 the numbers referring in order to sepals, petals, stamens and pistils. The flower is therefore unsymmetrical. Stonecrop is symmetrical; if you know it you should compare it with spring-beauty; it has sepals 4 or 5 , petals 4 or 5 , stamens 8 or 10 , (twice 4 or 5 ) and pistils 4 or 5 . Compare also a flax blossom the formula of which is $5,5,5,5$.

Purslane is a smooth, prostrate, thick-leaved, succulent plant, the bane of gardeners. It flourishes in the hottest part of July and August. See if its formula is 2, 5 or 6, 7 to 20,3 to 8 . Compare Lesson LXXII, especially Figure 117. 


\section{LESSON CXV.}

\section{The Mallow Family.}

\section{Malvaceae.}

Several very common plants belong to this family, the holyhock, common mallow, the Hibiscus, the velvet leaf, the bladder-ketmia and the Althaea. From some of these flowers we should learn what monadelphous stamens are. The word means of one brotherhood. A tube rises up from the short claws of the petals which bears the stamens. We should also learn what valvate in the bud and convolute in the bud mean. Valvate describes the sepals the edges of which just meet. Convolute describes the corolla the edges of which overlap in such fashion that each petal has one edge in and one out. We can also learn well from the Althaea, the holyhock and mallow what an involucel is. Look for a sort of secondary or exterior calyx 6 to 9cleft around the holyhock and Altheae, of three pieces around the mallow.

\section{LESSON CXVI.}

\section{The Geranium Family.}

\section{Geraniaceae.}

This family contains Oxalis or wood-sorrel, the touchme-not, the Pelargonium, the Geranium or cranesbill and the nasturtion, called also the Nasturtium, but this, one must not forget is also the generic name of the watercress.

The Oxalis may be studied as it grows wild almost everywhere and it can also be had at the greenhouse; it is 
symmetrical with the formula $5,5,10,5$. The carpels are united into a five-celled ovary. Find out how these open; it is unusual.

The nasturtion offers us a good opportunity to learn what an irregular flower is. When the parts of the same whorl are unlike we call the flower irregular. This is noticeably true of the petals of a pansy or violet; one is spurred. See if the sepals of the nasturtion are not unlike; see if the petals are not, and the stamens. Examine also the touch-me-not and see that it has a spurred sepal larger than the rest.

\section{LESSON CXVII.}

\section{The Pulse Family.}

The Leguminosae.

To this family belong the locust and the honey-locust, trees, the bean and pea, climbing vines, the redbud, a shrub, the Wistaria, a woody twiner, the white and red clover, sweet clover and alfalfa, etc., herbs. It will thus be seen that size and form have little to do with the make up of families. The flowers of this order have usually papilionaceous corollas and we should acquaint ourselves with this in the pea, bean, locust, redbud, etc.; they have five petals, the lower called the keel, carina, two side ones called the wings, alae, and a large enveloping one called the banner, vexillum, see Figure. We have seen monadelphous stamens in the Malvaceae; we may now see diadelphous stamens in the clover and alfalfa, or better still in the locust and pea as the flowers are larger; the word diadelphous means in two groups. Generally there are nine joined by their filaments in one group and one. alone or almost separate from the rest. 
We should also learn well what a legume is as this is the peculiarity that gires its name to the family. A legume is a one-celled pod, splitting into halves but bearing the seeds all on the rentral suture only, in one row. The pea and the bean pods are very familiar examples. Consult Lesson LXXXVI for a great service rendered the soil by the Leguminosae. In North Carolina peas are sown along with other crops and they restore the soil for them as clover does for us in the North.

\section{LESSON CXVIII.}

\section{The Teasel Family.}

\section{The Dipsaceae.}

The wild teasel may be seen everywhere along roadsides, in pastures and in untilled corners. Its flowers are in a dense, large head, conical-elliptical, surrounded by an involucre that is loose and longer than the head, but the stamens are not syngenesious. The plants are stout, coarse, prickly biennials. The fuller's teasel, supposed to be derived from this, has the points of its chaffy head, hooked, and is used for raising a nap on woolen cloth. The chaff of the wild teasel has long, tapering, straight points.

The calyx is coherent but has no pappus. The corolla is four-cleft, nearly regular, a fine purple in color. The numerous corollas give the head an appearance as pleasing as its many daggers will allow. The four stamens grow separate on the corolla-tube. 


\section{LESSON CXIX.}

\section{The Thistle Family.}

\section{The Compositae.}

The sunflowers, the asters, the goldenrods, the daisies, the burdock, the Spanish needles, the cockle-burs, the dog-fennel, the tansy, the ironweed, the yarrow, the everlastings, the chrysanthemum, the lettuce, the ragweeds and many other less known plants belong to this family. The dandelion may be found eight months or more of the year; hunt in it or the sunflower for these characteristics of the family: Flowers in a close head, surrounded by an involucre of many bracts, which are generally green and with stamens united by their anthers, (syngenesious). If the blossom of the dandelion is compared with Figure 72 a good beginning can be made with this family. It may be easily noticed that all the flowers of the dandelion are alike. Compare now the sunflower; two kinds will be found, the showy outside flowers with a strap-shaped corolla and the less showy flowers of the head with tubular corollas. Do asters, daisies and thistles resemble the dandelion or the sunflower most, in this respect? Much profit and pleasure could come from a comparison of all the compositae with the dandelion. Examine the involucre of the dandelion; is it green? compare it with the involucre of the common everlasting; is it green? compare the involucre of the bur-marigold, (common beggar-tick) generally called Spanish needle. Notice that the Spanish needle's involucre is very leaf-like, is expanded into a small blade, is veined like a small leaf, and helps us to see that the bracts of the involucre are reduced leaves. Compare Lesson XLIII.

Compare carefully the pappus on twenty different kinds 
of flowers belonging to the compositae; the Spanish needle, sunflower and dandelion would be very instructive in this respect. The dandelion has a hair-like pappus, Figure-89. The Spanish needle's is reduced in number to two or in some species to three or four, barbed stickers shown in Figure 101. The pappus of the sunflower consists of small scales which easily fall off. The chrysanthemum, ox-eye daisy, is entirely without pappus, i. e., apetalons.

Notice that the plaintain-leaved everlasting is dioecious, the cocklebur and ragweed are monoecious while the dandelion has perfect flowers. We will learn by this study how very different in many important respects are the flowers that are classed together in this family.

It is interesting that the prickly lettuce and many other compositae have all their flowers ligulate, the everlasting and some others have all theirs tubular, while the asters and a large number in addition have both ligulate and tubular flowers.

\section{LESSON CXX.}

\section{The Nightshade Family.}

\section{The Solanaceae.}

To this family belong, beside nightshade, the potato, the tomato, the tobacco, the ground cherry and the Jamestown weed ("jimson weed") Datura stramonium. Study these common plants for the order characteristics; having studied all but one see if you can tell by a further study of that one why it should belong to the same order. There will be real progress in the effort to do this.

Datura has a green, prismatic, five-toothed calyx, a corolla three inches long, white and five-toothed; there are five stamens on the corolla tube and alternate with its 
lobes. The fruit is a many-seeded capsule armed with prickles. Is it two or four-celled at the bottom of the capsule? At the top? The jimson is a tall, strong, illscented annual; smooth, with a green stem, leaves alternate, sinuate and toothed. The flowers grow in forks of the stem on short peduncles. Compare the nightshade and potato blossoms with this and each other, natt by natt, calyx, corolla, androecium, and gynoecium. The importance of doing this can hardly be overstated. No teacher and no book can do this for you.

\section{LESSON CXXI.}

\section{The Mint Family.}

\section{Labiatae.}

Study this family through the everywhere common catmint or the garden sage or the little gill-over-the-ground. Herbs with square stems opposite aromatic leaves, a more or less two-lipped corolla, four stamens, two long and two short (didynamous) or only two (diandrous) and a deeply four-lobed ovary with style rising between the smooth or only slightly rough seeds.

The much-used pennyroyal belongs to this fanily.

\section{LESSON CXXII.}

\section{The Pokeweed.}

\section{The Phytolaccaceae.}

The only plant described under this family in Gray's Manual is pokeweed. Whatever qualities this plant has are, therefore, the qualities of the family. We can learn accurately from the fruit or flower what a raceme is. The 
flower has five sepals, no petals, ten stamens, and five carpels united into a pistil of as many cells. The styles are ten. The dark purple berries are eagerly eaten by- the robins and thrushes and should be left, on unused ground, for bird food. The succulent stem six to nine feet high grows from a large, poisonous root used in medicine. Emerson's definition of a weed is "A plant whose virtues have not yet been discovered." Pokeweed has at least two known virtues and is therefore not a weed.

\section{LESSON CXXIII.}

\section{The Morning-Glory Family.}

\section{The Convolvulaceae.}

A very common plant cultivated for ornamental purposes, the morning-glory, a very useful herb, the sweet potato and a very interesting group of twining parasites, the dodders, belong to this family.

The morning-glory has a calyx of five long, narrow, imbricated (overlapping) sepals, and a corolla of five united petals. The corolla is purple, blue or white and funnelformed. When the parts of the corolla are united, we determine of how many parts it is composed by the number of its lobes or the number of seams by which it appears to have grown together. Try to determine the number of parts of several gamopetalous flowers in this way, as, for instance, the holyhock, the hibiscus, the pumpkin, the watermelon, cucumber, potato, ground-cherry, sage, catnip and sunflower and any other gamopetalous flower with which you meet. Much practice alone will help you in all cases to determine. The gynoecium, (a name for all the carpels put together) of the morning-glory is composed of three carpels. How can you determine this? Cut across 
the ovary and count the cells, this is one way. How many stigmas are there? This is another way. Is the ovary lobed to any degree? How many styles are there? Any one of these ways may mislead the beginner sometimes; the thing to do is to look at many flowers with care and compare your observations with what others have seen.

The sweet potato rarely blooms when it is raised for commercial purposes as it is with us. It furnishes a good example of a trailing vine that roots at the joints. See how many kinds of support you can find stems adopting; as, for instance, upright stems, the oak; right-handed twining stems, the morning-glory; left-handed, twining stems, the hops; (as one looks down on a twining hop it moves with the hands of a watch held face upward; as one looks down on a morning-glory it twines against the hands of a watch. The hop goes with the sun; the morning-glory against it. Does the bean twine like hop or morning-glory? The hop is called a sinistrorse climber, the morning-glory a dextrorse;) climbing by tendrils that are branches, grapevines; climbing by tendrils that are leaflets, the pea; climbing by tendrils that are stipules, greenbrier; stems that bend over to the ground for rest, the raspberry, etc. The sweet potato is propagated with us by means of slips raised in hotbeds. One bushel will produce from 3,000 to 5,000 slips (Bailey).

The dodder Cuscuta arvensis, frequents wet places. I have seen it along the flood plains of the Wabash at Peru and Terre Haute and I have no doubt it occurs all along the stream. It is a small, white, or yellowish-white-stemmed, leafless plant that twines about smartweed and other river-bottom plants, grows suckers on the side next to the host and lives at its expense. It has small whitish scales instead of leaves and all its floral organs are pale. The calyx has five obtuse lobes; the corolla lobes are acuminate, longer than the tube, inflexed. It has five stamens alter- 
nate with the corolla lobes; the ovary is two-celled, fourovuled. This description is written from Cuscuta arvensis; it will vary somewhat with the species of the dodder.

Notice how small is the stem and how large in proportion are the flowers and seed pods. The dodder has met the usual fate of the parasite; it gets digested food from its host and does not need foliage leaves; it has none; it has doubtless lost them from disuse; its pale scales are rudimentary organs. It has no roots extending to the ground for the same reason; and no stem to support it. It matures many seeds as this is its means of survival. It can cling, pierce its host and get food and reproduce. It is wholly a dependent, a degenerate. It is eminently adapted to its kind of life. It is not necessarily on the road to extermination but it is barred from the independent, aspiring life of the oak or thistle. It has been sentenced for laziness and theft to a sort of perdition, not to extinction. Don't seek for a permanent thousand-dollar clerkship for yourself or for your boy at Washington.

\section{LESSON CXXIV.}

\section{The Nettle Family.}

\section{The Urticaceae.}

The elms belong to this family. The slippery elm, called also the red elm, may be known among elms by its large, (four to eight inches) and very rough leaves, its slippery inner bark and its nearly sessile flowers. The bark is used in medicine. The leaves are oblique, Figure 26, alternate and two-ranked as are the leaves of all the elms. The American or white elm is somewhat commoner, especially in lawns, see Lesson IV, Figure 5. Its leaves are two to 
four inches. Its buds and branchlets are smooth and its branches never corky. Its fruit is winged all round notched at the apex and ciliate. Its flowers are on slender drooping pedicels.

There are two other, rarer elms, the cork or rock elm and the wahoo or winged, both of which have corky branches. The first of these has its leaf-veins nearly twice as close together as any other elm; about thirty in the cork-elm to seventeen in the American elm and the leaf is very smooth.

The English or field elm is sometimes met with as a shade tree; it has very small leaves, about half the size of the American elm.

The elm blossoms are polygamous; that is some are sterile and some are fertile and some are perfect. They have a four to nine-cleft calyx, four to nine stamens and a one to two-celled ovary; the seed is single,

The hackberry also belongs to this order; it bears a globular drupe (fruit with stone within) on a peduncle twice as long as the petioles of its leaves and can be told among our trees by this and its oblique leaves. Its polygamous-monoecious flowers have a five to six-parted calyx with five to six stamens and a one-celled ovary.

The osage orange, so extensively used for hedges, the mulberry, the nettle, monoecious or dioecious, the hop and the hemp, dioecious, all belong to this family and may be studied in comparison with other members of it.

LESSON CXXV.

\section{The Plane-Tree Family.}

The Platanaceae.

Our sycamore is our largest tree; it is common along all our streams; it is striking on account of its smooth, white bark and its large palmately veined, palmately lobed leaves. 
The petioles of the leaves cover and protect the buds as long as the leaves hang on. Its flowers are monoecious, in separate, naked heads. Scales are mingled among the flowers. The seeds are furnished with a ring of hairs about the base.

\section{LESSON CXXVI.}

\section{The Walnut Family.}

\section{The Juglandaceae.}

This family is made up of the hickories and walnuts. Of the walnuts there are two kinds common with us, the black walnut, with the unhulled nut round, and the white walnut, called also the butternut, with the unhulled nut elliptical, hairy, and glutinous; both kinds have alternate, pinnately compound leaves. The wood and the bark of the butternut are lighter colored than those of the black walnut, and, in general, have fewer leaflets on a leaf (five to seven pairs) than the black walnut ( 7 to nine pairs). All the trees of this family are monoecious, the sterile flowers being in catkins, (aments) and the fertile single or in small clusters. The fertile flowers of the walnut have a four-toothed calyx which bears four small petals; styles and stigmas, two. The sterile have a calyx three to six cleft and clinging to a bract, twelve to forty stamens.

There are two common shellbark hickories, one Carya alba, which bears a thin-shelled nut about an inch long and has from five to seven leaflets. The other, Carya sulcata has a nut one and a half to two inches long with a thick shell hard to crack; it has seven to nine leaflets. The sterile catkins are generally in threes. The fertile flowers have a four-toothed calyx and two to four sessile 
stigmas. There are also two bitternuts; one, called pignut, has from five to seven leaflets with the catkins and young leaves smooth. The nut is oblong or oval, one and a half to two inches long. The other is swamp-hickory with nut globular and about an inch long, and having seven to eleven leaflets. The catkins and young leaves are more or less pubescent. The bark of the bitternut does not peel off in strips running up and down the tree as it does in the shagbark. The walnuts and shagbarks are among our most valuable timber.

\section{LESSON CXXVII.}

\section{The Oak Family.}

\section{The Cupuliferae.}

The oaks, birches, beeches, the chestnut, the hazelnut, the water-beech, the ironwood, and the alders belong to the Cupuliferae. The word means cupule-bearing or cupbearing; it refers to the cup in which the acorns or nuts grow. This is made up of many small scales in the oak; the many scales form a sort of four-lobed involucre in the chestnut, and beech. The scale is leaf-like in the waterbeech, and a closed sack in the ironwood. The flowers are monoecious, the sterile in catkins, the fertile, solitary or variously clustered. It is quite impossible to get a knowledge of these small, inconspicuous green or greenish-yellow flowers without carefully examining them in the spring. The leaves of all this family are pinni-veined, see Figures $13,14,16,17,20$ and 26 . The birch may be known by its bark peeling off in horizontal strips, the ironwood by its bark shredded longitudinally, the oaks by the fact that they bear acorns; the hazelnut is a bush not a tree, and 
its nut is inclosed in leaf-like bracts. We should learn from this lesson what a cupule is-the cup of an acorn, what a pinni-reined leaf is. What a lobed leaf is (white and red oaks have them). What a serrate leaf is (the chestnut and beech have them). What a chestnut-bur is Fig. 104. What monoecious trees are. Lessons XVIII and XIX.

Red oaks, of which we have four, have their lobes awned; Figure 16. White oaks, of which we also have four, have their lobes rounded, Figure 14. Chestnut-oak leaves have their leaves notched not lobed. Figures 13 and 17.

\section{LESSON CXXVIII.}

\section{The Willow Family.}

\section{The Salicaceae.}

The willows and poplars belong to this family. The white willow can be told by its yellowish twigs, and the whitish under side of its somewhat short leaves. It is one of the largest willows we have, is often planted on lawns.

The black willow has foliage of a much darker green, and is the common willow along streams.

The long-leaved willow has the notches, serrations, far apart on its long, narrow, whitish leaves.

The weeping willow no one can mistake on account of its drooping branches.

The "pussy willow" (Salix discolor) can be told by its thick aments, oblong-cylindrical, close-sessile, one inch or more long, appearing before the leaves in earliest April. These aments are the flowers of the willow. The family is dioecious, so seeds grow on only a part of the poplars and willows. 
In the "pussy willow" catkins, one flower will be found to each bract without a perianth. These bracts are dark red or brown becoming black and are clothed in long, glossy hairs.

There are at least fifteen other kinds of willows and some of these kinds have been cultivated by gardeners and intercrossed until many widely different varieties have been produced. That such a thing can be done is very interesting; it throws much light on our very many kinds of animals and plants. Read Darwin's "Animals and Plants Under Domestication."

The Carolina poplar, cottonwood, is much used as a shade tree on account of its beauty and rapid growth; it has large, crenate, deltoid, flat-petioled leaves. The Lombardy poplar has similar leaves but they are smaller, wider than long and the branches grow up almost straight close to the tree giving it a spire-shaped appearance by which it can be told.

The white poplar has leaves slightly lobed rather than notched, very white-tomentose below; the young twigs are white hairy as well.

\section{LESSON CXXIX.}

\section{The Iris Family.}

\section{The Iridaceae.}

This family, the Iridaceae, is introduced solely on account of the blue flag which grows in damp places along streams. Notice that its perianth is six-cleft, that it is adherent to the ovary, (is it in the lily?) and that it has but three stamens, the anthers of which open outward, extrorse, one under or outside of each of the three large 
expanded petalloid stigmas. Compare Lesson XLVI on the leaf-origin of the pistil. Notice the two-ranked, swordshaped, equitant leares.

Compare the flower of Iris with Crocus. Learn from these what an epigynous flower is, i. e., a flower in which the floral organs grow on the pistil. Is the perianth-tube of the crocus longer than it is in the iris? Does the crocus flower grow sessile on the corm? Are all the leaves of the crocus root-leaves?

\section{LESSON CXXX. \\ The Amaryllis Family. \\ The Amaryllidaceae.}

This family is important for us because the narcissus, snowdrop, amaryllis and daffodil, common garden flowers, belong to it. Figure 45 shows an amaryllis. It resembles the iris in having the perianth adherent to the ovary and it resembles the lily in having six colored divisions and six stamens. The narcissus and daffodils have a crown on the throat of the perianth. The daffodil is yellow with a large yellow crown. The narcissus is white with a small yellow crown. The snowdrop is white and without a crown. A main thing we should learn in this lesson is the intermediate character of the amaryllis family between the lily family and the iris family.

\section{LESSON CXXXI.}

\section{The Grass Family.}

\section{The Gramineae.}

The Gramineae include the wheat, oats, rye, barley, timothy-grass, orchard-grass, blue-grass, foxtail, Indian rice, or water oats, and Indian corn and many other sorts 
of grasses. A very large and most important order o plants as our cereals belong to it and it furnishes the chief food of domestic animals.

A good way to begin the study of this family is with oats in the flowering season.

Find the central stem of the "head," the axis of inflorescence; its several side branches; some of these are branched, others not. Oats furnishes a good example of a panicle, see page 173. See if each final branch or spikelet does not bear two or three flowers. At the base of each spikelet are two empty glumes. We call them glumes because they are not quite opposite and they are a little below the flower, otherwise we should call them an involucre. Is the spikelet that bears these glumes and the flowers above it flat? Find two more glumes for each flower, an outer, larger one that encloses the flower and the smaller one on the other side of the spikelet called the palet. If these two glumes were alike and opposite we should doubtless call them sepals; they are generally called the upper and lower palets. Find inside of these the three stamens growing distinct on the receptacle (hypogynous); the pistil is made up of a top-shaped, hairy ovary and two styles that are clothed with hair-like stigmas. At the base of the upper palet, between its edges, find two very reduced, bract-like scales called the lodicules. It is probable that these bractlets are all that is left of the perianth of the flower of the grasses. If this lesson is faithfully done and is followed by a similar lesson with wheat and the cereals and then with the larger grasses it will end in the ability to become acquainted with the grasses; an acquaintance that makes for one many friends for the grasses are found everywhere. The Gramineae can be told by their hollow stems with closed joints, their alternate two-ranked leaves, the sheaths of which are split on the side opposite the blade, and their hypogynous, solitary flowers in the axils of two- 
ranked glumes. Corn should be studied as an interesting variation, having the staminate flowers at the top, and many pistillate flowers, as many at least as there are grains afterward, on a spadix, the cob, and surrounded together by the glumes, the husks.

In many parts the Indian rice may be studied to see an instance in which the pistillate flowers are above the staminate. This arrangement favors cross-pollination from another plant, since pollination is almost sure to occur when the wind is blowing. I saw, August 3rd, 1903, Indian rice from ten to fifteen feet high at English Lake, Indiana. Experiments are being carried forward now looking toward its cultivation for economic purposes.

\section{LESSON CXXXII.}

\section{The Pine Family.}

\section{Coniferae.}

To this family belong the pine, spruce, arborvitae, fir, tamarack, (hackmatack or larch) white cedar, hemlock, yew, juniper and bald cypress. The leaves of the pine are in clusters or bundles of from two to five and are evergreen. The larch has its leaves clustered many in a fascicle, and they are deciduous. The leaves of the spruce are scattered singly over the branch and each has a short brown petiole. Compare Lessons VI, VII and XXXIX, Figures 7, 8, 9 and 64 . The leaves of the hemlock are scattered singly and have a green petiole. The leaves of the fir are scattered singly, have no petiole but are attached to the stem by a disc. Compare Lesson III, Figure 4.

The arborvitae has its leaves scale-like in four rows on the stem; they completely corer the stem; the spray is 
flat. The common juniper has its awl-shaped leaves in whorls of three; the red cedar has its scales awl-shaped appressed to the stem, four-ranked, but the spray is roundish, not flat like arborvitae. The bald cypress, so common on the margins of lakes and rivers and in the swamps of Florida and sometimes cultivated in the North has its leaves on a flat spray which it sheds together with the leaves. As it grows in a few feet of water its roots require some means of getting air. This is furnished by the spongy knees which grow up from the roots and the enlarged base of the trunk which is also porous.

The family name means cone bearers, in allusion to the cones made up of many scales under which the winged seeds, Figure 81, grow.

\section{LESSON CXXXIII}

\section{The Ferns.}

\section{Filices.}

This order comprises the beautiful ferns which grow everywhere in damp, shady places. The maiden hair fern is the one known, perhaps, to most people. Its frond stems are shining black; its botanical name is Adiantum pedatum; the specific name pedatum is in allusion to the mode of branching of the frond which is supposed to resemble a bird's foot. For the general characteristics of ferns, see Lesson LX and Figures 94 to 100.

The spores on the under side of the leaves should be sowed on damp soil in a flower pot under a bell glass or fruit can and the growth of the fern watched. It should be seen that fern fronds grow up from an underground stem-a rootstock which also bears roots. Notice that 
the spores of the maiden hair fern are covered by the reflexed margins of the frond. This covering is called the indusium. Notice that the fruit dots often grow at the end of a comparatively large vein of the frond and that the indusium is sometimes attached by a central stem (peltate) to the frond; sometimes it is attached all along one side. These are items which will help in the classification of the ferns.

\section{LESSON CXXXIV.}

\section{The Mosses.}

The mosses carpet the damp shaded ground in early spring; they also grow on rocks and trees and some of the species grow where water trickles over a bank. If this water is charged heavily with lime, formations of petrified moss in large masses may be formed. Such formations are common about Richmond, Indiana. Every one should study the mosses enough at least to learn the difference between what botanists call the sporophyte (spore bearing plant) and the gametophyte (gamete bearing plant). The gametes are the two cells, male and female, which unite in sexual reproduction.

In the mosses the sporophyte consists of the long naked stem which grows from the summit of the leafy moss plant which is the gametophyte.

Sporophyte and gametophyte are of somewhat equal size in the mosses; at least both can easily be seen. The connection between them is slight. The dried sporecup and its stem can easily be pulled out from the slight depression it occupies at the top of the leaf-bearing moss, the gametophyte.

In the mosses it is easy to understand the alternation 
of generations among plants. The microscopic spores which are borne in large numbers in the sporecup at the top of the sporophyte are scattered by the wind; when they alight on damp soil or rocks or bark they begin to grow and ultimately they produce not a sporophyte like they came from but a gametophyte, a leafy moss some of them, in most species male plants, and some of them female. These bear, in the rosettes at the top of the stem, each in its apporpriate cup, the male and female cells. When rain or dew unites the heads of male and female moss plants, the male cells swim across and find their way to the female cells; one male cell unites with one female cell and from the union a sporophyte grows up. In this manner are produced in alternation gametophyte, gametes, sporophyte, spores, gametophyte, etc.

Alternation of generations plays an important part in both the plant and animal kingdoms; it cannot be studied with any other material to better advantage than it can with mosses. Among ferns the gametophyte, Figuie 98, is so small that it is usually overlooked. Among our seedbearing plants it is so small it can only be studied with a compound microscope.

There are many other families of plants which cannot be noticed even briefly in a work like this. The following are a few more that may be studied through the common and well known representatives given with each:

Borraginaceae through Hound's Tongue (sticktight).

Anonaceae through Papaw.

Fumariaceae through Dutchman's Breeches.

Linaceae through Common Flax.

Rutaceae through Prickley Ash.

Vitaceae through Grape.

Sapindaceae through Buckeye, Maple and Box Elder. Anacardiaceae through Sumach.

Calycanthaceae through Sweet Scented Shrub. 
Saxifragaceae through Hydrangea, Mock Orange, Currant and Gooseberry.

Crassulaceae through Stonecrop.

Hamamelideae through Sweet Gum.

Onagraceae through Primrose.

Cucurbitaceae through Gourd, Pumpkin, Squash, Muskmelon, Watermelon and Cucumber.

Umbelliferae through Harbinger-of-Spring (Pepper-andSalt), Wild Parsnip, Carrot, etc.

Cornaceae through Dogwood and Sour Gum.

Caprifoliaceae through Honeysuckle, Elder, Black Haw and Weigela.

Rubiaceae through Galium (Bed Straw, Goose Grass).

Ebenaceae through Persimmon.

Asclepiadaceae through Milkweed.

Polemoniaceae through Phlox and Valerian.

Scrofulariaceae through Mullein, Butter and Eggs, Snap

Dragon and Speedwell.

Bignoniaceae through Catalpa.

Plantaginaceae through Plantain. Consult Lesson XXI.

Polygonaceae through Dock, Knotweed and Buckwheat.

Lauraceae through Sassafras.

Commelinaceae through Spiderwort.

Araceae through Indian Turnip, Skunk Cabbage and Calamus. 


\section{GLOSSARY}

Adherent, applied to the calyx, etc., when growing fast to the ovary. Alae, Side petals of a papilionaceous flower.

Ament, 173. A pendulous spike.

Androecium, the stamens taken together.

Anther, Pollen-container at top of filament.

Apetalous, without petals.

Auriculate, with ear-shaped appendages.

Bract, a reduced leaf, 66.

Bulb, a fleshy scaled underground leafbud, 73.

Calyx, the outside whorl of a flower.

Carina, the lower united petals of a papilionaceous flower.

Carpel, "a simple pistil or one part of a compound pistil."

Catkin, Same as ament, 173, apendulous spike.

Cleistogamous, a term applied to flowers that do not open.

Complete, applied to a flower containing the four whorls.

Convolute, overlaping with one edge in and one out.

Corm, the solid enlarged fleshy base of a stem.

Corolla, the second whorl of floral leaves.

Corymb, 173.

Determinate, applied to flower clusters blooming first at the center or top.

Diadelphous, applied to stamens united into two sets by their filaments.

Diandrous, Having two stamens.

Dicotyledonous, Having two seed-leaves.

Epigynous, on the pistil.

Equitant, applied to enfolding upright leaves like those of blue flag. Extrorse, opening outward.

Feather-veined, veined like a beech leaf. Same as pinni-veined, 200.

Filament, the support of the anther in a stamen.

Free, said of the flower whorls when they are separate.

Gamete, 207, 160.

Gametophyte, 207.

Gamapetalous, petals united.

Glumes, the chaffy bracts of the grasses.

Gynoecium, the carpels taken together.

Head, 173. 
Hypogynous, under the gynoecium. Said of parts growing on the receptacle.

Imperfect, said of a flower lacking stamens or pistils.

Incomplete, said of flowers lacking some whorl.

Indusium, the covering of sori in ferns. Figs. 95, 96, 100.

Inflorescence, flower arrangement on the stem.

Introrse, opening inward.

Involucel, a secondary involucre.

Involucre, a whorl or whorls of bracts around a flower or flower cluster.

Irregular, Having the parts of the same whorl unlike, 189.

Legume, the fruit of the Leguminosae-a bean, 189.

Ligulate, Strap shaped. Like the corolla of dandelion.

Lodicules, 204.

Monocotyledonous, with one cotyledon.

Monadelphous, united by filaments into one group, 188 .

Ovary, the seed bearing, lower part of the carpel.

Pales, the thin, upper, hyaline chaff of the grasses.

Palmately Veined, veined like a sugar-maple. Fig. 22.

Panicle, 173.

Papillionaceous, said of a corolla like the bean and pea have

Parallel Veined, veined like corn. Fig. 27.

Peduncle, a flower stalk.

Peltate, umbrella shaped.

Perfect, said of a flower having stamens and pistils.

Perianth, a term for both calyx and corolla.

Perigynous, around the gynoecium; said of petals and stamens when they grow on the calyx.

Persistent, not falling off.

Petal, one of the parts of the corolla.

Petiole, the stem of a leaf.

Pinnately, veined like the elm, Fig. 26, or compound like Fig. 25.

Pistil, "the seed-bearing organ of the flower."

Polygamous, bearing pertect, fertile and sterile flowers.

Polypetalous, having more than one petal.

Raceme, 173.

Rootstock, 206, Fig. 53.

Sepal, one of the parts of the calyx.

Sessile, without a stem.

Silicle, a short pod like shepherd's purse has.

Silique, a long pod like mustard has.

Sori, the fruit dots on underside of fern leaves, $89,90$. 
Spermatophyte, a seed-bearing plant.

Spike, 173.

Spikelet, 204.

Sporangium, a spore cup. Figs. 97, 105.

Spores, 207, 89, 96.

Sporophyte, 207.

Stamen, one part of the androecium.

Stigma, the topmost, naked part of the pistil.

Style, it connects the stigma and ovary.

Symmetrical, said of a flower with same number of parts in each whorl.

Syngenicious, applied to stamens united by their anthers, 191.

Thyrse, a thick much compounded panicle, 173.

Unsymmetrical, said of a flower with differing numbers in its whorls.

Valvate, edges meeting.

Vexillum, the large uppermost petal of the leguminosae, as the bean. 


\section{INDEX.}

Abutilon, 24, 25,* 26.

Agave, 109.

Alga, 43.

Alternation of Generations, 207.

Amaryllis, 38, 39, 203.

Ament, 173.

Anemophilous Plants, 48.

Animals and Plants, 148.

Annual Herbs, 50.

Antheridium of Moss, 159, 160.

Anthrax, 142.

Ants, 44 .

Apple, 9, 13, 28, 75.

Archegonium of Liverwort, 160.

Asexual Reproduction, 152.

Aspen, 16.

Bacteria, 141.

Balm of Gilead, 16.

Bark, 122, 125, 128.

Bean, 40, 79.

Beech, Leaf-Arrangement of, $27,28$.

Beech Leaf, Petiole of, 27.

Beech Tree, 1, 2, 13.

Berberidaceae, 183.

Biennial Herbs, 51.

Birch, 22, 28.

Bracts, 66.

Branches, Horizontal, 12, 13.

Branches, Vertical, 12, 13.

Branching, Deliquescent, 8.

Branching, Excurrent, 6, 7.

Branchlets, Pendant, 11, 60.

Broom-Corn, 35.

Bryant, Wm. Cullen, Quotation from, 127.

Buds, 57, 58.

Bud Scales, 58, 71 .

Bulb Scales, 72, 73.

Burns, Robert, Quotation from, 89.

Burdock-Bur, 92.
Butterflies, 41.

Cane, 35.

Caryophyllaceae, 187.

Catkin, 173.

Cedar, 9.

Cell, The 151.

Cherry Tree, The Wild, 3, 9.

Chestnut-Bur, The, 92.

Chestnut Leaf, The, 18.

Chlorophyll, 146.

Cleistogamy, 45.

Climate, 49-62.

Clover, 26, 132.

Cockle-Bur, 92.

Compass-Plant, 16.

Compositae, 191.

Complete Flower, 32.

Coniferae, 205.

Convolvulaceae, 194.

Corn, 34, 116.

Corn and Soil, 22, 23,

Corymb, 173.

Creeper, Virginia, 14.

Cross-Pollination, Experiments in, 46.

Crowfoot Family, 182.

Crow-Roost, 94.

Cruciferae, 185.

Cupuliferae, 200.

Currents of Water, 93.

Cut-Leaved Maple Leaf, 17.

Dandelion, Pappus of, 74,84 , 86.

Datura, 137.

Deciduous Forests, 4, 54 .

Desert Plant, 109

Diatoms, 104, 105.

Dioecious Species, 36.

Dispersal of Seeds, 82-100.

Elm Tree, The, 8, 13.

Elm Leaf, 19.

Entomophilous Plants, 47.

Epilobium, 38.

Erigenia Bulbosa, 158.

*When the paging is given in this type an illustration will be found. 
Evergreen Leaves, 55, 56, 57.

Excurrent Branching, 6.

Felices, 206.

Fern, 89, 90, 121, 206.

Fern, 89, 90, 121.

Fern Leaf, Section of, 54 .

Fibro-Vascular Bundle of Smilax, 114, 115.

Fibro-Vascular Bundle of Corn, 116.

Fibro-Vascular Bundle of Geranium, 117, 118.

Fibro-Vascular Bundle of Fern, 121.

Fire-Weed, 38.

Fir-Tree, The, 6, 7.

Food, 135.

Forestry, 113.

Fruit and Seed-Dispersal, 94.

Fuel, 137.

Genera, 178.

Geranium, The Cross-Section of a Stem of, 117, 189.

Ginkgo Leaf, 19.

Goethe, 40, 152.

Gramineae, 203.

Grass Family, 203.

Greenbrier Leaf, 19.

Growth, 164.

Hazelnut, 13.

Head, 174.

Heart-Wood, 122, 124.

Hedge, 13.

Horse-Chestnut Leaf, 18.

Hyacinth, Water, 153.

Hydrophytes, 101.

Inflorescence, 172

Infusorial, Earth, 105.

Insects and Pollination, 40, 41.

Indaceae, 202.

Juglandaceae, 198.

Katahdin, Mt., Birches Growing on, 22.

Koch, Robert, 142.

Labratae, 193.

Land Plants, 111.

Larch, European, 11.

Leaf, The, 62-77.

Leaf-Arrangement, 28.

Leaf, Cross-Section of, 76.

Leaf, Foliage, 62.

Leaves, Compound, 18, 19.
Leaves, Evergreen, 55.

Leaves, Effect of Shadow on, 19.

Leaves, Shapes of, 17, 18, 19.

Leguminosae, 189

Lenses, 170.

Lettuce, Prickley, 16.

Lichen, 43.

Light, 1-31.

Lilac Leaf, 19.

Lily, 73.

Linden Seed, 82.

Live Oak, 61, 62 .

Lumber, 137.

Magnoliaceae, 183.

Malvaceae, 188.

Maple Spray, 15.

Measuring a Tree, 5, 6 .

Medullary Rays, 119, 120, 123, 140.

Microscopic Plants, 104.

Mint Family, 193.

Mistletoe, 140.

Mountain-Ash Leaf, 18.

Monecious Species, 33, 35 .

Morning-Glory, 14, 194.

Morphology of the Laef, 62-77.

Mosses, 207.

Moths, 41.

Mulberry, 36.

Mullein, 20, 21, 52.

Mushrooms, 144, 145.

Mustard Family, 185.

Nettle Family, 197.

Night Shade Family, 193.

North Indiana Field, 101, 103

Norway Spruce, 11 12, 60.

Nostoc, 154.

Nuts, 95.

Oak Family, 200.

Oak Leaves, 17.

Oedogonium, 158.

Onion, 23.

Orchid, 41, 42.

Oxalis, 26.

Palm, 30, 31.

Palmetto Brushes, 116.

Pampas-Grass, 99.

Panicle, 173.

Papaveraceae, 184.

Pappus, 74, 84, 86, 87.

Parasitic Plants, 140. 
Pasteur, 143.

Pea, Garden, 77.

Pea, Sweet, 78.

Perennial Herbs, 53.

Persimmon Tree, 59.

Petals, 67.

Petiole, Behavior of, 13, 14, 15 .

Phylolaccaceae, 194.

Pilobolus, 97.

Pine, 10, 19, 29, 205.

Pine Leaf, Section of, 56 .

Pine, Pitch, 9, 10.

Pink Family, 205.

Pistils, 70.

Pistillate Flowers, 33.

Plankton, 104.

Plant Societies, 101, 102-113.

Plantain, 37, 198.

Poke-weed Family, 194.

Pollen, 32, 33, 34.

Pollination, 32-48.

Poplar, Carolina, 16.

Poplar, Lombardy, 14, 16.

Portulaccaceae, 187.

Protandry, 38.

Protogyny, 37.

Protoplasm, 151.

Pulse Family, 189.

Pumpkin Vine, 14.

Purslane, 110, 111, 187.

Quarter-Sawed Oak, 123.

Raceme, 173.

Ragweed, 93.

Ranunculaceae, 182.

Red-Oak Leaf, 17.

Respiration of Plants, 150.

Rings of Growth, 120, 122.

Rose Leaf, 19.

Rose Family, 180.

Rosette Leaf Arrangement, 20 , 21.

Root, 130, 131.

Salicaceae, 201.

Saprophytes, 144, 145.

Sap-wood, 122.

Scott, Sir Walter, Quotation from, 16.

Seeds and Spores, Size of, 89.

Seed Dispersal, 82-100.

Seeds that Cling, 91, 92, 93.

Sepals, 67.

Sexual Reproduction, 156, 157.
Shapes of Leaves, 17, 18, 19.

Sleep of Plants, 24, 25, 26.

Smartweed Embryo, 162.

Smilax, 114.

Soil, Influence of, 22, 23.

Solanaceae, 193.

Solomon's-Seal, 53.

Southey, Robert, Quotation from, 65.

Spanish Needle, 91, 92.

Species, 178.

Sperms of Moss, 160.

Spike, 173.

Spines, 65.

Spirogyra, 147, 157.

Sporangium of Fern, 96.

Spore Dispersal, 97.

Spores and Seeds, 89.

Spring Flowers, 127.

Spruce, Norway, 11, 12, 13, 60 .

Stamens, 69.

Staminate Flowers, 33.

Starch, 134.

Stem, Influence of Climate and Soil on, 22, 23.

Stem, Main Duty of, 21.

Stems, 114-129.

Stomata, 54, 56, 107.

Storms, 49.

Streptococcus, 155.

Struggle for Existence, 80.

Sweet Pea, 78.

Sycamore, 19.

Sycamore-Maple Leaf, 18.

Symboisis, 42, 43, 95.

Table of Seed Dispersal, 100.

Tamarack, 11, 29.

Teasel Family, 190.

Tendrils, 77-79.

Thistle, 88, 191 .

Transpiration, 64 .

Tumble Weed, 98.

Twinleaf Embryo, 163.

Twining Plants, 79.

Umbel, 173.

Urbccaceae, 197.

Uses of Plants, 134-139.

Vetch, 133.

Violet Family, 186.

Walnut, 98, 198.

Walnut Tree, 3, 4, 5 .

Water, Currents of, 93. 
Water Hyacinth, 153.

Water-Lily, White, 105, 106, 184.

Water Plants, 101.

Willow Family, 201.

Wind, Influence of, on Plants, $60,61,62$.

Winged Seeds, 82, 83.
Whittier, John Greenleaf, The Palm, 138.

Xerophytes, 109.

Yeast, 155.

Yellow Chestnut Oak, Leaf of, 17.

Young Plants, 166. 


\section{JUN 151910}



LIBRARY OF CONGRESS

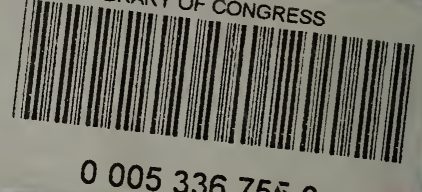

00053367550 